Florida International University FIU Digital Commons

FIU Electronic Theses and Dissertations

University Graduate School

3-27-2014

\title{
Design and Synthesis of S-ribosylhomocysteine Analogues
}

Christiane Chbib

christiane_chbib@yahoo.com

DOI: $10.25148 /$ etd.FI14040870

Follow this and additional works at: https://digitalcommons.fiu.edu/etd

Part of the Biochemistry, Biophysics, and Structural Biology Commons, and the Chemicals and Drugs Commons

\section{Recommended Citation}

Chbib, Christiane, "Design and Synthesis of S-ribosylhomocysteine Analogues" (2014). FIU Electronic Theses and Dissertations. 1233. https://digitalcommons.fiu.edu/etd/1233

This work is brought to you for free and open access by the University Graduate School at FIU Digital Commons. It has been accepted for inclusion in FIU Electronic Theses and Dissertations by an authorized administrator of FIU Digital Commons. For more information, please contact dcc@fiu.edu. 


\section{FLORIDA INTERNATIONAL UNIVERSITY \\ Miami, Florida}

\section{DESIGN AND SYNTHESIS OF S-RIBOSYLHOMOCYSTEINE ANALOGUES}

A dissertation submitted in partial fulfillment of

the requirements for the degree of

DOCTOR OF PHILOSOPHY

in

CHEMISTRY

by

Christiane Chbib 
To: Dean Kenneth G. Furton

College of Arts and Sciences

This dissertation written by Christiane Chbib and entitled Design and Synthesis of Sribosylhomocysteine Analogues, having been approved in respect to style and intellectual content, is referred to you for judgment.

We have read this dissertation and recommend that it be approved.

$\begin{array}{r}\hline \text { Bernard Gerstman } \\ \hline \text { Kathleen Rein } \\ \hline \text { Xiaotang Wang } \\ \hline \text { David Chatfield } \\ \hline \text { Stanislaw Wnuk, Major Professor }\end{array}$

Date of Defense: March 27, 2014

This dissertation of Christiane Chbib is approved.

$\begin{gathered}\text { Dean Kenneth G. Furton } \\ \text { College of Arts and Sciences }\end{gathered}$
$\begin{array}{r}\text { Dean Lakshmi N.Reddi } \\ \text { University Graduate School }\end{array}$

Florida International University, 2014 
(C) Copyright 2014 by Christiane Chbib

All rights reserved. 


\section{DEDICATION}

I dedicate this dissertation to my parents and my husband for their unconditional

love, support and encouragement. Also to the LORD who is always my guide and my source of happiness. 


\section{ACKNOWLEDGMENTS}

I would like to extend my heartfelt gratitude to my mentor Dr Wnuk for the opportunity you gave me to be part of his lab. I want to thank you for your patience, your assistance and your care in my professional development and beyond. You left a major impact in my life. Thank you for setting the example of how an expert and professor should be and thank you for all the help you provided me in every chance you had.

I would like to thank my husband for all the patience and the help that you provided me to be able to accomplish my ph.D, your encouragement and dedication gave me the effort and the will to complete my ph.D. The presence of my family in my life (even though they live abroad), has impacted me and my goals and led to the person I am today. Thank you for all the priceless care and dedication.

I would like to extend a big thank to my lab mates, you were not only friends but a family to me. Thank you for your support in my research and the help you provided me. Thank you for the professional and friendly environment we had in the lab for the last 6 years and for all the great moments we celebrated together.

A special thank for Dr Adam Sobzak, Dany Lumpuy, Jesse Pulido, Cesar Gonzales, Jessica Zayas, yong Liang, Ramanjaneyulu Rayala and Mukesh Mugdal for all the help that you provided in my research and all the support.

I would like to thank the United Stated of America, for all the great opportunities that allowed me to have and to be able to live the American dream.

Last but not least, I would like to thank GOD who gave me more than I deserve in a lot of things, thank you for the strength that you provided me. 


\section{ABSTRACT OF THE DISSERTATION \\ DESIGN AND SYNTHESIS OF S-RIBOSYLHOMOCYSTEINE ANALOGUES}

by

Christiane Chbib

Florida International University, 2014

Miami, Florida

Professor Stanislaw Wnuk, Major Professor

Bacteria are known to release a large variety of small molecules known as autoinducers (AI) which effect quorum sensing (QS) initiation. The interruption of QS effects bacterial communication, growth and virulence.

Three novel classes of $S$-ribosylhomocysteine (SRH) analogues as potential inhibitors of S-ribosylhomocysteinase (LuxS enzyme) and AI-2 modulators of QS were developed. The synthesis of 2-deoxy-2-bromo-SRH analogues was attempted by coupling of the corresponding 2-bromo-2-deoxypentafuranosyl precursors with the homocysteinate anion. The displacement of the bromide from $\mathrm{C} 2$ rather than the expected substitution of the mesylate from C5 was observed. The synthesis of 4-C-alkyl/aryl-Sribosylhomocysteine analogues involved the following steps: (i) conversion of the Dribose to the ribitol-4-ulose; (ii) diastereoselective addition of various alkyl or aryl or vinyl Grignard reagents to 4-ketone intermediate; (iii) oxidation of the primary hydroxyl group at $\mathrm{C} 1$ followed by the intramolecular ring closure to the corresponding 4-Calkyl/aryl-substituted ribono-1,4-lactones; (iv) displacement of the activated 5-hydroxyl group with the protected homocysteinate. Treatment of the 4-C-alkyl/aryl-substituted SRH analogues with lithium triethylborohydride effected reduction of the ribonolactone 
to the ribose (hemiacetal) and subsequent global deprotection with trifluoroacetic acid provided 4-C-alkyl/aryl-SRHs.

The 4-[thia]-SRH were prepared from the 1-deoxy-4-thioribose through the coupling of the $\alpha$-fluoro thioethers (thioribosyl fluorides) with homocysteinate anion. The 4-[thia]SRH analogues showed concentration dependent effect on the growth on las $(50 \%$ inhibitory effect at $200 \mu \mathrm{g} / \mathrm{mL}$ ). The most active was 1-deoxy-4-[thia]-SRH analogue with sufur atom in the ring oxidized to sulfoxide decreasing las gene activity to approximately $35 \%$ without affecting $r h l$ gene. Neither of the tested compounds had effect on bioluminescence nor on total growth of $V$. harveyi, but had however slight inhibition of the QS. 


\section{TABLE OF CONTENTS}

Chapter

Page

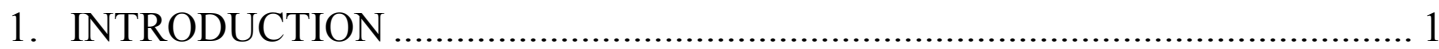

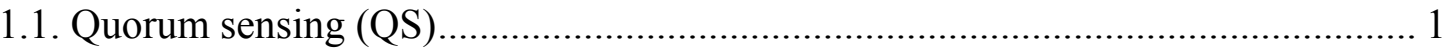

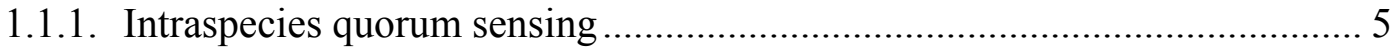

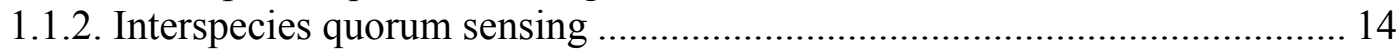

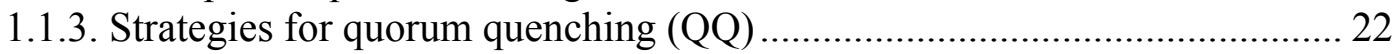

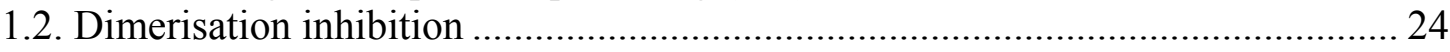

1.2.1. Examples of dimer inhibitors of other enzymes.......................................... 25

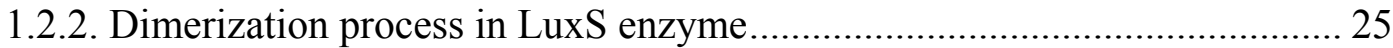

1.3. Inhibition of LuxS enzyme by substrate analogues...................................... 28

1.3.1 S-ribosylhomocysteine substrate analogues.............................................. 29

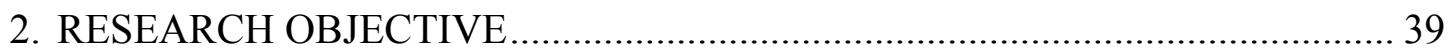

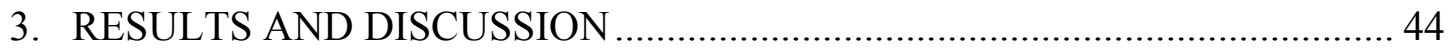

3.1 Design and synthesis of 2-halo substituted $S$-ribosylhomocysteine analogues ..... 44

3.1.1. Synthesis of 2-bromo-2-deoxy-S-ribosylhomocysteine analogues.............. 46

3.1.2. Synthesis of 2-deoxy-2-fluoro-S-ribosylhomocysteine analogues................ 50

3.2. Design and synthesis of 4-C-alkyl/or aryl-S-ribosylhomocysteine analogues...... 53

3.2.1. Rationale for the synthesis of the 4-substituted SRH analogues:.................. 53

3.2.2. Synthesis of 4-C-substituted SRH analogs:.................................................... 54

3.3. Design and synthesis of 4-[thia]-S-ribosylhomocysteine analogues........................... 65

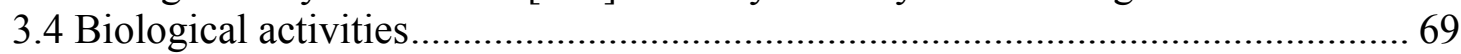

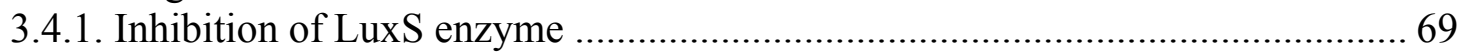

3.4.2. Screening against $r h l$ and las in P. aeruginosa QS ..................................... 69

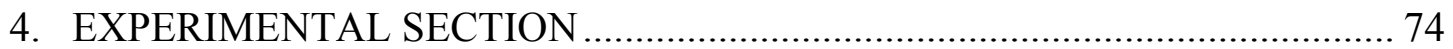

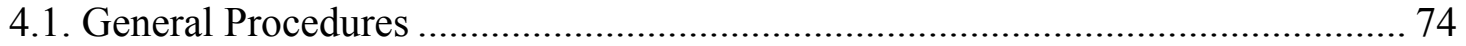

4.2. Synthesis of the inhibitors and their spectroscopic characteristization.................. 76

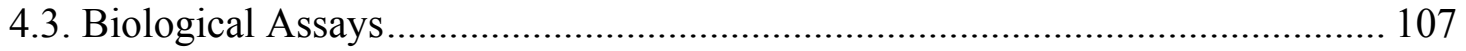

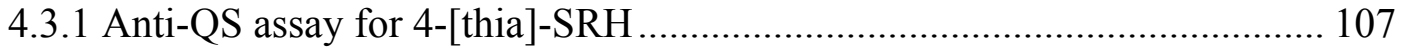

4.3.2. Anti-QS assay for 4-C-alkyl/aryl-SRH ……............................................ 108

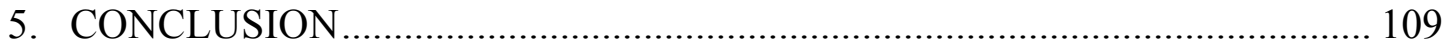

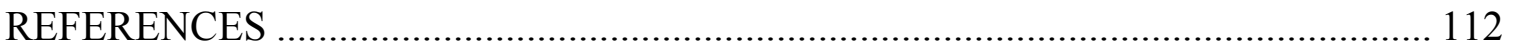

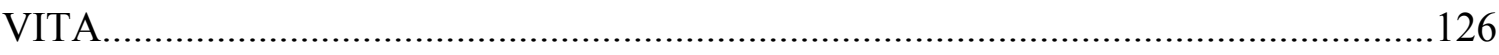




\section{LIST OF TABLES}

Table $\quad$ Page

1. Different Quorum sensing pathways in bacteria............................................. 4

2. Representative AHLs and their function in Gram negative bacteria. ................... 9

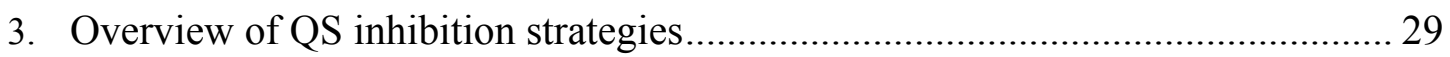

4. Ki values of different substrate inhibitors of LuxS......................................... 33

5. Anti-QS activity and bacterial growth of 4-[thia]-SRH derivatives. ................... 73 


\section{LIST OF FIGURES}

Figure

Page

1. The signal molecules in quorum sensing process in Gram positive and negative bacteria. 2

2. Quorum sensing model: Cell to cell communication............................................ 3

3. Chemical structures of QS signaling molecules (QSSM) ................................. 5

4. The different signaling in Gram positive (A) and negative bacteria (B).............. 6

5. QS mediated by peptides pheromones and two-component regulatory systems in Gram-positive bacteria............................................................................ 7

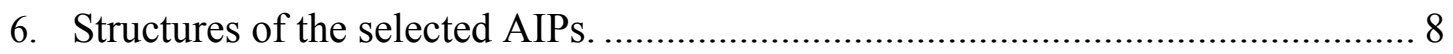

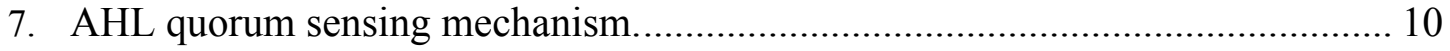

8. Quorum sensing pathways in $E$. coli and $S$. typhimurium and $V$. harveyi............ 12

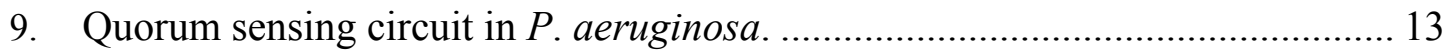

10. (A) Crystal structure of $\operatorname{LuxS}^{64}$; (B) A stereoview of the active site of LuxS.... 15

11. Interaction of the furanosyl borate diester (AI-2) with the amino acids at the

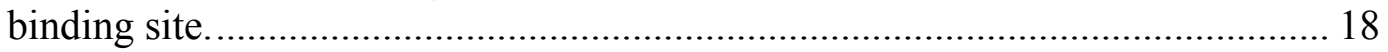

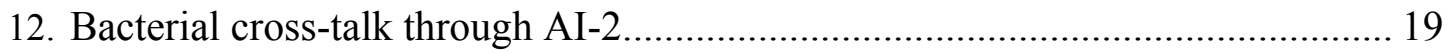

13. A schematic illustration of AI-2 with LuxP..................................................... 19

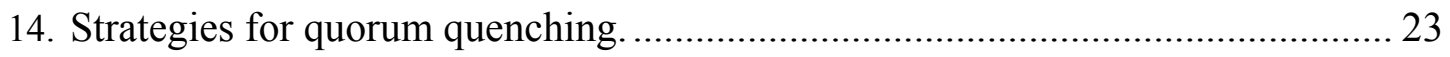

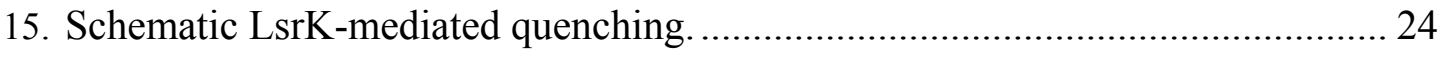

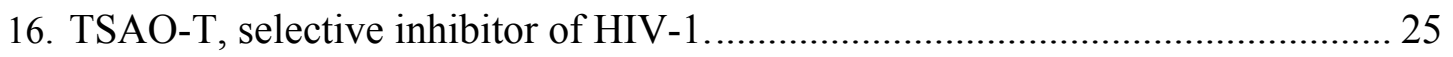

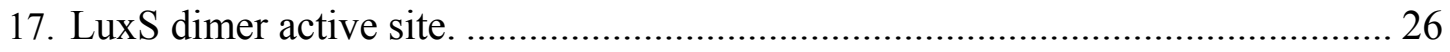

18. Schematic representation of isoceles orientation of the LuxS .......................... 27

19. SRH analogues proposed as potential dimerization inhbitors. ........................... 28 
20. Substrate inhibitors of LuxS enzyme designed by Zhou and coworkers. 30

21. Substrate inhibitors of LuxS enzyme designed by Pei and coworkers 31

22. Substrates of LuxS enzyme synthesized by Wnuk and coworkers..................... 33

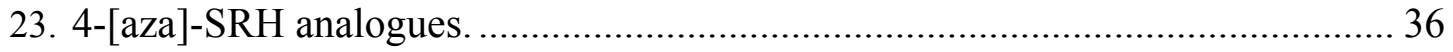

24. AHL analogues modified with isothiocyanates and bromoacetamides. ............... 38

25. Targeted 2-deoxy-2-halo-S-ribosylhomocysteine analogues.............................. 39

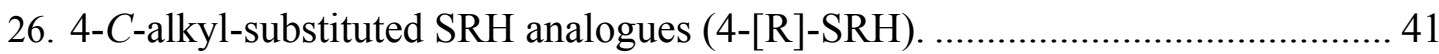

27. The SRH analogues with furanose ring oxygen substituted by sulfur ([4-thia]$\mathrm{SRH})$ and the expected thio-analogues of DPD............................................... 43

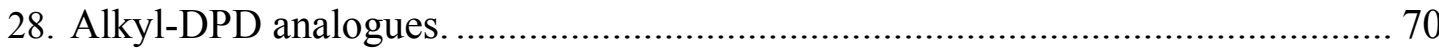

29. Thia-S-ribosyl-L-homocysteine analogues screened for their anti-QS activity

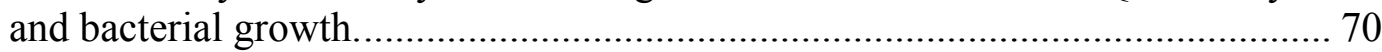

30. Structure of meta-chloro/or bromo-thiolactone ............................................... 71

31. Effect of 4-thio-SRH analogues on $r h l$ expression in $P$.lasI-lacZ expression in

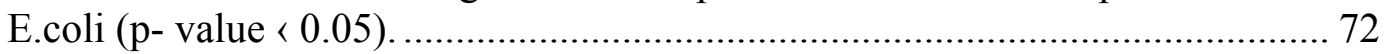

32. Effect of 4-thio-SRH analogues on las expression in $P$.rhlaI-lacZ expression in E.coli (p-value $<0.05)$.

33. Numbering of the carbons in $S$-ribosylhomocysteine analogues and the corresponding sugar precursors used for the nomenclature of compounds and description of their NMR spectra. 


\section{LIST OF SCHEMES}

Scheme

Page

1. Biosynthesis of $N$-(acyl)-L-homoserine lactone. 10

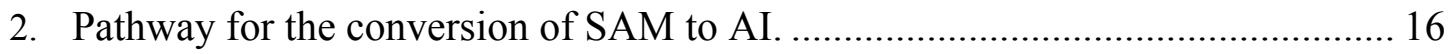

3. Proposed mechanism of LuxS- catalyzed reaction. ........................................... 17

4. Biosynthetic pathways for the formation of DPD and AI-2 ........................... 21

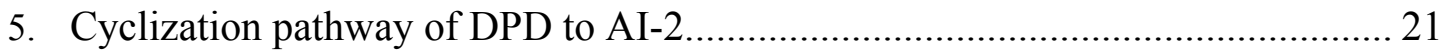

6. Proposed mechanism for the inhibition of LuxS by 3-Br-SRH......................... 34

7. A plausible mechanism for the inhibition of LuxS by 3-F-SRH....................... 35

8. Plausible mechanism for the time-dependent inhibition of LuxS by 4-aza-SRH

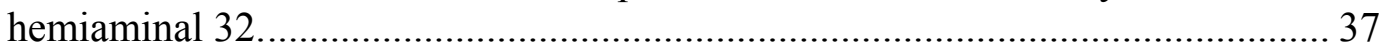

9. A possible mechanism of inhibition of LuxS by 2-[F]-SRH. ............................. 40

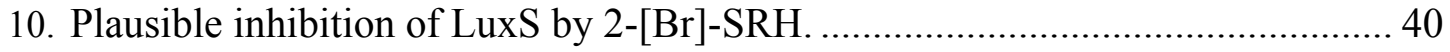

11. A plausible mechanism for the inhibition of LuxS by 4-[R]-SRH analogues..... 42

12. A plausible inhibition of LuxS by 2-[F]-SRH via $\mathrm{H} 2$ abstraction. ........................ 44

13. A plausible inhibition of LuxS by 2-[F]-SRH via $\mathrm{H} 3$ abstraction........................ 45

14. A plausible inhibition of LuxS by $2-[\mathrm{Br}]-\mathrm{SRH}$ via $\mathrm{S}_{\mathrm{N}} 2$ mechanism. .................... 46

15. Synthesis of the 2-bromo-2-deoxy-5-O-mesyl-ribono/arabinono lactone derivatives.

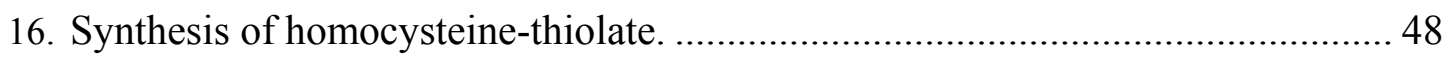

17. Coupling between the 5-O-mesyl-2-bromopentafuranose lactone and homocysteine thiolate.

18. Model reaction of bromo-lactones with propylthiol .......................................... 50

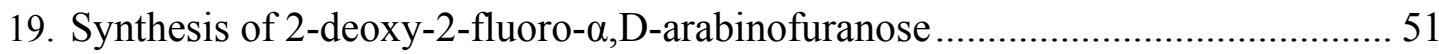

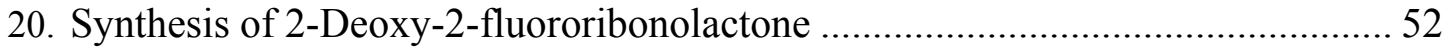


21. The proposed plan for the synthesis of 2-deoxy-2 fluoro-D-arabinofuranose...... 53

22. A plausible inhibition of LuxS by 4-alkyl/or aryl-[SRH] substrate..................... 54

23. Preparation of the precursors for the synthesis of 4-C-alkyl-SRH analogs......... 55

24. Diasteroselective addition of Grignard reagents to the 4-ketoribitol precursors. . 56

25. Proposed model for the diastereoseletive addition of the Grignard reagent to

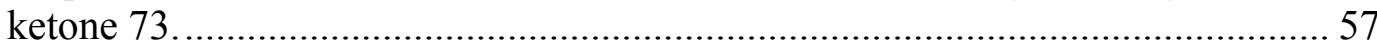

26. Oxidation of 4-C-substituted ribitols with TPAP and NMO .............................. 59

27. Mechanism of oxidation with NMO/TPAP and ring closure to ribonolactone.... 59

28. Attempted synthesis of hemiacetals 81 by Swern oxidation. .............................. 60

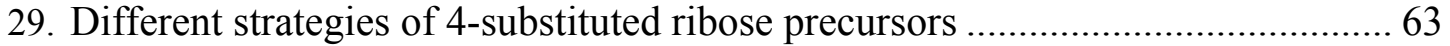

30. Coupling of mesyl-ribonolactone derivative with homocysteine thiolate and

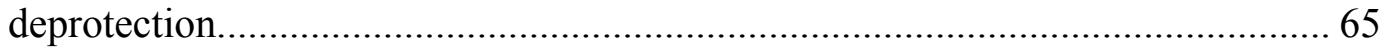

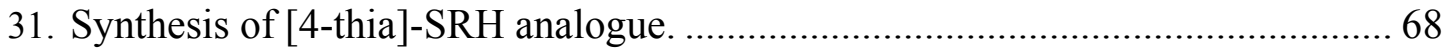




\section{LIST OF ABBREVIATIONS}

$\AA$

$\mathrm{ABC}$

Ac

AHL

AI

AIP

$\mathrm{Aq}$

ATP

BHL

$\mathrm{Bn}$

Boc

CAI-1

$\mathrm{CH}_{2} \mathrm{Cl}_{2}$

$\mathrm{COCl}_{2}$

CPS

$\mathrm{CrO}_{3}$

Cys84

d

DAST

DCC

dd
Angstrom

ATP-binding cassette

Acetyl

$\mathrm{N}$-acyl homoserine lactone

Autoinducer

Autoinducing peptides

Aqueous

Adenosine triphosphate

$N$-butyryl-HSL

Benzyl

tert-butyloxycarbonyl

Cholerae autoinducer 1

Dichloromethane

Oxalyl chloride

4-chlorophenylsulfonamide group

Chromium trioxide

Cysteine 84

Doublet

Diethylaminosulfur trifluoride

$N, N^{\prime}$-dicyclohexylcarboiimide

Doublet of a doublet 


\begin{tabular}{|c|c|}
\hline DHFR & Dihydrofolate reductase \\
\hline DHMF & $(2 R, 4 S)$ - and $(2 S, 4 S)$-2,4-dihydroxy-2-methyldihydrofuran-3-one \\
\hline DIC & Diisopropylcarbodiimide \\
\hline DMAP & 4-( $N, N$-dimethylamino)pyridine \\
\hline DMF & $N, N$-dimethylformamide \\
\hline DMSO & Dimethyl sulfoxide \\
\hline DOP & Dioxopentanal \\
\hline DPD & 4,5-dihydroxy-2,3pentanedione \\
\hline E.coli & Escherichia coli \\
\hline $\mathrm{E} 1 \mathrm{cB}$ & Elimination unimolecular conjugate base reaction \\
\hline E-57 & Glutamine 57 \\
\hline${ }^{19} \mathrm{~F}$ NMR & Fluorine-19 nuclear magnetic resonance \\
\hline $\mathrm{g}$ & Gram \\
\hline $\mathrm{h}$ & Hour \\
\hline Hcy & Homocysteine \\
\hline Her-2 & Human epidermal growth factor receptor- 2 \\
\hline HHQ & 4-hydroxy-2-heptylquinoline \\
\hline His & Histidine \\
\hline HIV-1 & Human immunodeficiency virus \\
\hline HKPH & Histidine kinase protein $\mathrm{H}$ \\
\hline HPLC & High-performance liquid chromatography \\
\hline HRMS & High resolution mass spectroscopy \\
\hline
\end{tabular}




\begin{tabular}{|c|c|}
\hline HTH & Helix-turn-helix motif \\
\hline IC50 & The half maximal inhibitory concentration \\
\hline$J$ & Coupling constant in $\mathrm{Hz}$ (NMR) \\
\hline $\mathrm{K}_{2} \mathrm{CO}_{3}$ & Potassium carbonate \\
\hline KDA & KiloDalton \\
\hline$K_{\mathrm{i}}$ & Inhibition constant \\
\hline LDA & Lithium diisopropylamide \\
\hline $\mathrm{LiEt}_{3} \mathrm{BH}$ & Lithium triethylborohydride \\
\hline LiHMDS & Lithium bis(trimethylsilyl)amide \\
\hline $\operatorname{LuxR}_{v i}$ & LuxR in $V$. harveyi \\
\hline $\mathrm{m}$ & Multiplet (NMR) \\
\hline M & Moles per Liter \\
\hline $\mathrm{m} / \mathrm{z}$ & Mass to charge ratio (MS) \\
\hline$m$ BTL & meta-Bromothiolactone \\
\hline MCPBA & meta-Chloroperoxybenzoic acid \\
\hline$m \mathrm{CTL}$ & meta-Chlorothiolactone \\
\hline $\min$ & Minutes \\
\hline $\mathrm{mL}$ & Milliliter \\
\hline Mol & Mole(s) \\
\hline Ms & Mesyl \\
\hline MS & Mass spectroscopy \\
\hline MTAN & 5'-methylthioadenosine nucleosidase \\
\hline
\end{tabular}




\begin{tabular}{|c|c|}
\hline NADH & Nicotinamide adenine dinucleotide \\
\hline $\mathrm{NaIO}_{4}$ & Sodium periodate \\
\hline NBS & $N$-Bromosuccinimide \\
\hline NFSi & $\mathrm{N}$-fluorobenzene sulfonamide \\
\hline $\mathrm{NH}_{3}$ & Ammonia \\
\hline NMO & $N$-methylmorpholine $N$-oxide \\
\hline NNRTI & Non-nucleoside reverse transcriptase inhibitor \\
\hline${ }^{\circ} \mathrm{C}$ & Degree Celsius \\
\hline OdDHL & $N$-(3-oxododecanoyl)-HSL \\
\hline P. aeruginosa & Pseudomona aeruginosa \\
\hline PG & 2-Phosphoglycolic acid \\
\hline $\mathrm{Ph}$ & Phenyl \\
\hline PQS & Pseudomonas Quinolone Signal \\
\hline p-TSA & $p$-Toluenesulfonic acid \\
\hline $\mathrm{q}$ & Quartet (NMR) \\
\hline QQ & Quorum quenching \\
\hline QS & Quorum sensing \\
\hline QSSM & Quorum sensing signaling molecule \\
\hline RHKs & Receptor-histidine kinases \\
\hline $\mathrm{rt}$ & Room temperature \\
\hline $\mathrm{s}$ & Singlet (NMR) \\
\hline S. typhimurium & Salmonella typhimurium \\
\hline
\end{tabular}




\begin{tabular}{|c|c|}
\hline SAH & $S$-Adenosyl-L-homocysteine \\
\hline SAM & $S$-Adenosyl-L-methionine \\
\hline $\mathrm{SbCl}_{3}$ & Antimony trichloride \\
\hline SRH & $S$-Ribosylhomocysteine \\
\hline $\mathrm{t}$ & Triplet (NMR) \\
\hline TBAF & Tetra- $n$-butylammonium fluoride \\
\hline TBDMS & $t$-Butyldimethylsilyl \\
\hline$t$-Bu & tert-Butyl \\
\hline TCEP & Tris(2-carboxyethyl)phosphine \\
\hline TEA or $\mathrm{Et}_{3} \mathrm{~N}$ & Triethylamine \\
\hline TFA & Trifuoroacetic acid \\
\hline THF & Tetrahydrofuran \\
\hline THMF & $(2 S, 4 S)$-2-methyl-2,3,3,4-tetrahydroxytetrahydrofuran \\
\hline TMSOTf & Trimethylsilyl trifluoromethanesulfonate \\
\hline TPAP & Tetrapropylammonium perrenthenate \\
\hline $\operatorname{Tr}$ & Trityl \\
\hline V. harveyi & Vibrio harveyi \\
\hline$\alpha$ & Alpha \\
\hline$\beta$ & Beta \\
\hline$\gamma$ & Gamma \\
\hline$\delta$ & Delta chemical shift in parts per million (NMR) \\
\hline$\mu$ & Micro \\
\hline
\end{tabular}




\section{INTRODUCTION}

\subsection{Quorum sensing (QS)}

Bacteria are known to release a large variety of small molecules. They also produce and respond to diffusible signal molecules (termed autoinducers or pheromones). Cell to cell communication in bacteria is shown to be accomplished through the exchange of extracellular signaling molecules called autoinducers. ${ }^{1-4}$ This process is defined as QS where bacteria are allowed to coordinate gene expression. The concept of quorum sensing (QS) was discovered in the luminescent marine bacterium Vibrio fischeri. ${ }^{5}$ Light emission (the Luciferase enzyme) was only expressed when the organisms were associated with their fish or squid symbiotic hosts. The mechanism behind it was uncovered demonstrating that the expression of luciferase-encoding genes is related to a factor secreted by the cells and accumulates as cell density increases. Bioluminescence, a QS dependent behavior in Vibrio, was observed as a light production that was controlled by the secretion and the detection of small signal molecules. ${ }^{6-9}$ When a specific threshold is reached (Figure 1), programmed changes in gene expression coordinate populationdependent behavior. ${ }^{5}$ Some of the changes that occur include biofilm formation, toxin and virulence secretion in addition to sporulation and swarming ability. QS was employed as a novel target for drug design especially in relation to pathogenic bacteria as Pseudomonas aeruginosa, Salmonella typhimutium, Yersinia enterocolitica and others. ${ }^{10}$ Autoinducer (AI) molecules are molecule facilitators that are conventionally divided into two groups. Acyl homoserine lactones (AHL, AI-1), ${ }^{11}$ used in Gram negative bacteria and oligopeptides used in Gram positive bacteria (Figure 1). However the QS process is not limited to the previous two groups only, but include a universal group of autoinducer- 
2 (AI-2) found in both Gram positive and negative bacteria. ${ }^{12-16}$ It has been proposed that AI-2 represent a possible means by which different bacteria communicate with each other contrary to the intraspecies communication mediated by other autoinducers. ${ }^{12,17}$

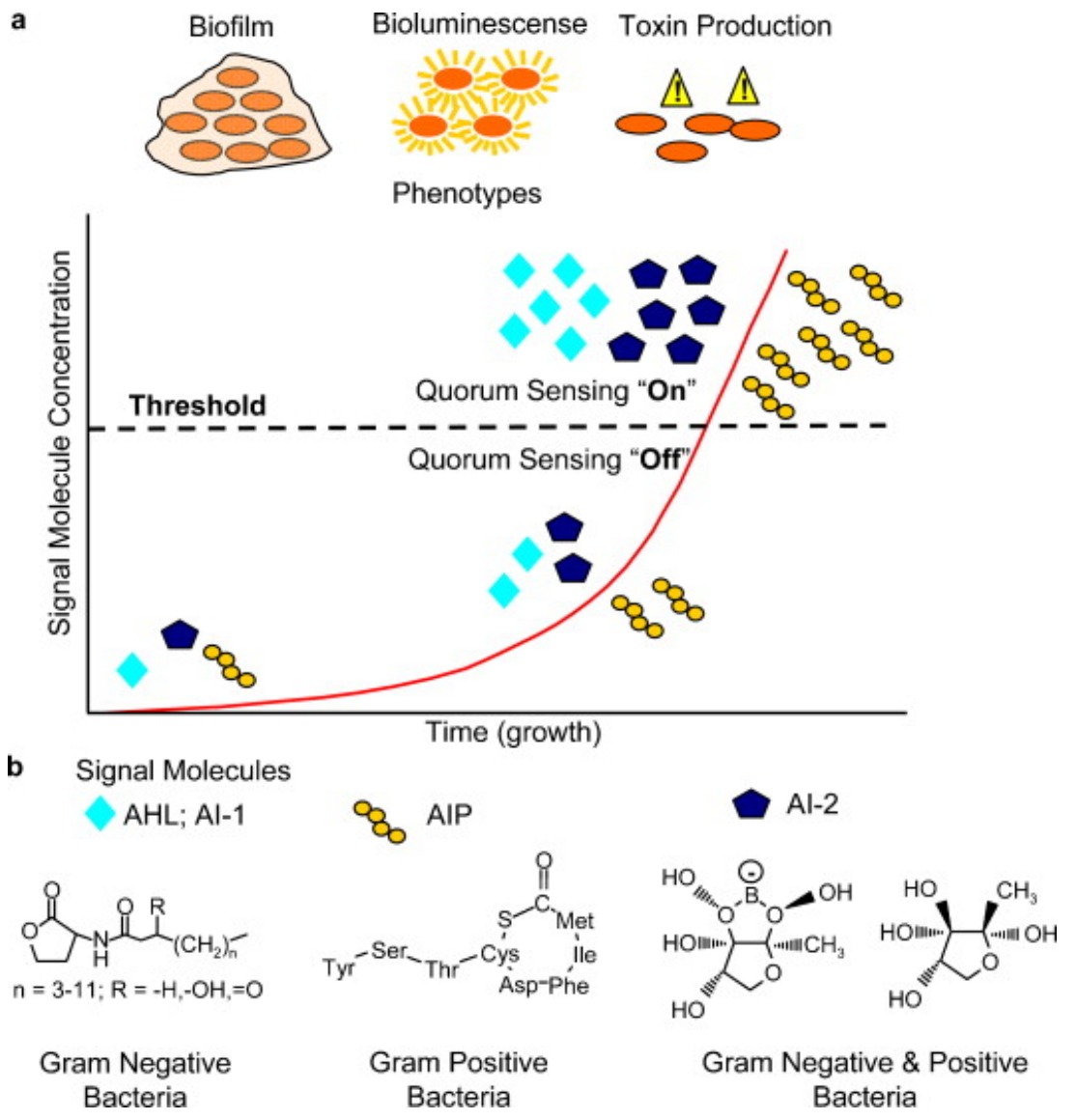

Figure 1. The signal molecules in quorum sensing process in Gram positive and negative bacteria. ${ }^{18}$

QS was demonstrated to regulate many important traits including biofilm formation, virulence and gene transfer between bacteria. ${ }^{4,19}$ Understanding QS may simplify the means to inhibit or silence QS pathway and weaken bacterial pathogenicity. Most new antibiotics are the derivatives of older generations which present a universal threat when it comes to bacterial resistance. This leads to the necessity of the research for new antimicrobials with different mechanism of actions. Quorum sensing, is the process of 
population dependent bacterial cell-cell signaling, which has a major impact on accelerating the bacterial virulence. It is considered an interesting target for new research in antibiotics. Antibacterials are divided into either bacteriostatic (inhibit bacterial growth) or bactericidals (cause bacterial cell death). ${ }^{17}$ The rise of a new family of antibacterial that belongs to neither but in fact operates by reducing selective pressure like quorum sensing mechanism has generated major interest. ${ }^{19}$

The process of quorum sensing involves three major characters ${ }^{4}$ (Figure 2): (1) synthase, (2) signal, and (3) sensor. The synthase is the basic part of the model, since it initiates the process of quorum sensing by synthesizing small-molecule signals called autoinducers (AI) which when detected by the sensors at a threshold level generate gene expression.

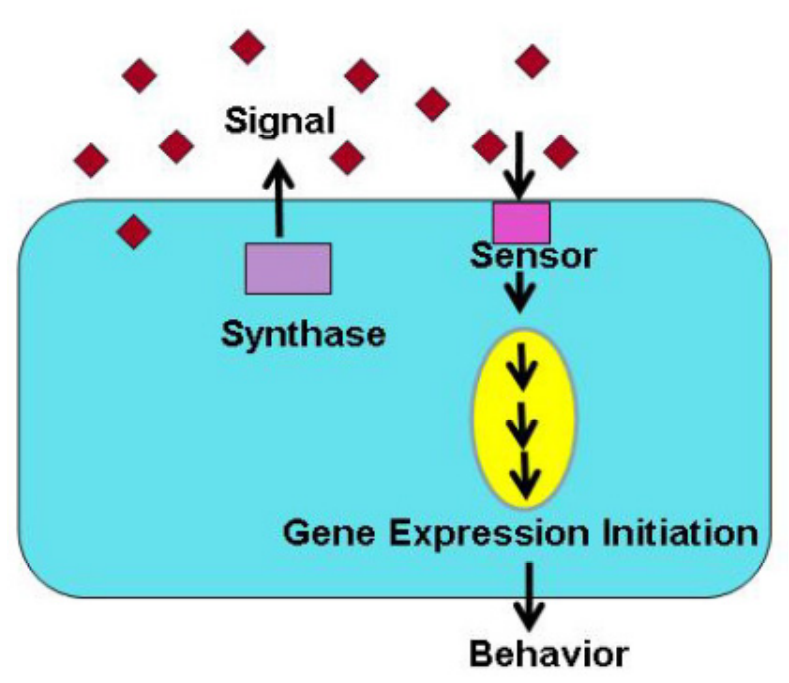

Figure 2. Quorum sensing model: Cell to cell communication. ${ }^{4}$

QS signaling molecules (QSSM) or autoinducers are categorized into three major classes $^{20,21}$ as illustrated in Table 1 and also shown in Figure 1. They are (a) $N$ acylhomoserine lactone (AHLs) produced by Gram negative bacteria, (b) autoinducing 
oligopepetide derivatives (AIP; see also Figure 6) employed by Gram positive bacteria, and (c) autoinducer-2 (AI-2) derived from the precursor 4,5-dihydroxy-2,3pentanedione (DPD) used by both Gram positive and negative bacteria (Figure 3). Other recognized QSSM consist of alkyl quinolones, for example, Pseudomonas Quinolone Signal (PQS or HHQ), autoinducer- $3^{22}$ and cholerae autoinducer 1 (CAI-1). ${ }^{23}$

\begin{tabular}{|ccc|}
\hline Pathway & Signal molecule & Bacteria \\
\hline AI-1 & various AHLs & Gram negative \\
\hline PQS and HHL & $\begin{array}{c}\text { Pseudomonas quinolone signal } \\
\text { 4-hydroxy-2-heptylquinoline }\end{array}$ & Gram negative \\
\hline AI-3 & Epinephrine/Norepinephrine & Gram negative \\
\hline AI-2 & Furanosyl borate esters of DPD & Gram negative and positive \\
\hline AIP & various oligopeptides & Gram positive \\
\hline CAI-1 & $(S)$-3-hydroxytricedan-4-one & Gram negative $(V$. Cholerae $)$ \\
\hline
\end{tabular}

\section{Table 1. Different Quorum sensing pathways in bacteria. ${ }^{17}$}

AHLs (1, Figure 3) vary in the length and the oxidation state of the acyl side chain. ${ }^{24}$ Blackwell and co-workers ${ }^{21}$ found that the length of the acyl chain is critical for the activity of AHL. In the unique case of P.aeruginosa a specific signal molecule having quinolone motifs such as PQS and HHQ is released from the cell. ${ }^{18}$ AI-2, a furanosyl borate ester of DPD in $V$. harveyi 2, exists as non-borated in S. typhinium 2a (Figure 3). 
<smiles>[X]C(CCCC)CC(=O)N[C@H]1CCOC1=O</smiles>

AHL 1

$\mathrm{X}=\mathrm{H}, \mathrm{OH}$, or $=\mathrm{O} ; \mathrm{n}=0-10$<smiles>CC(C)(C)C1Nc2ccccc2C(=O)C1O</smiles>

PQS<smiles>CC(C)(C)C1=CC(=O)c2ccccc2NC1C(C)(C)C</smiles>

$\mathrm{HHQ}$<smiles>C[C@]12OCC(O)[C@@]1(O)O[B-](O)(O)O2</smiles>

Al-2 (used by $V$. harveyi)

2<smiles>C[C@@]1(O)OC[C@@H](O)C1(O)O</smiles>

Al-2 (used by $S$. typhinium)

2a

\section{Figure 3. Chemical structures of QS signaling molecules (QSSM). ${ }^{24}$}

\subsubsection{Intraspecies quorum sensing}

In Gram positive bacteria, signaling pheronomones are generally peptides. They signal through receptor-histidine kinases (RHKs) that are embedded in the membrane. ${ }^{25}$ The intraspecies communication in Gram-positive bacteria is through autoinducing peptides $(\mathrm{AIP})^{17}$ in the form of oligopeptides consisting of 5-20 residues, whereas in Gram negative bacteria, acetylated homoserine lactones (AHL) are used as autoinducers which consist of small molecules diffusible across the cytoplasmic membrane and able to bind to the regulatory proteins within the cell to trigger transcriptional changes. ${ }^{12,25}$

In Figure 4 part $A$, peptide signaling through receptor-histidine kinases (RHKs) in Gram positive bacteria shows that the extracellular signaling molecules bind to the sensor domain of the RHK leading to the activation via phosphorylation and dephosphorylation of the HK domain. Then gene expression is controlled at the level of transcription. In Gram negative bacteria (Figure 4 part $B$ ), small signaling molecules cross to the 
intracellular receptor protein $\mathrm{R}$. Upon binding, $\mathrm{R}$ is stabilized in a form that binds to DNA leading to the modulation of gene expression.

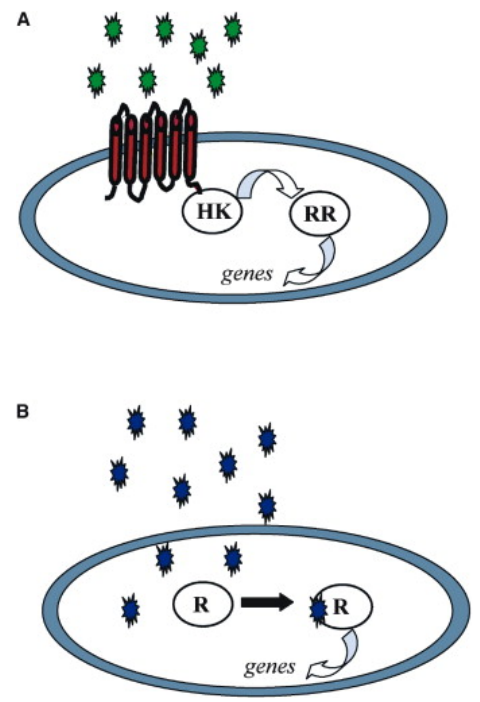

Figure 4. The different signaling in Gram positive $(A)$ and negative bacteria $(B){ }^{25}$

\subsubsection{Gram positive bacteria}

Intraspecies communication in Gram positive bacteria as $S$. aureus, is related to the secretion of an extracellular peptide AIP and to its accumulation. ${ }^{25}$ Upon reaching a threshold, AIP binds to the sensor protein (histidine kinase protein $\mathrm{H}, \mathrm{HKPH}$ ) located in the cell membrane of the bacteria and triggers the activation of the receptor-histidine kinase AgrC. HKPH is part of a two-component signal transduction system. The QS system includes the sensing protein (receptor) and a response-regulatory protein which controls gene activation and positive feedback regulation of AIP (Figure 5). Kinase protein $\mathrm{H}$ is activated when binding to AIP, leading to its autophosphorylation. The phosphoryl group is transferred to an aspartate residue D that undergoes subsequent phosphorylation leading to the activation of the response regulatory protein (peptidepheromone precursors). The latter is cleaved to afford the autoinducer signal exported by 
the ATP-binding cassette $(\mathrm{ABC})^{26}$. Once exported, AIP can be sensed by self and other bacteria.

Two Component SignalTransduction in Gram Positive Bacteria

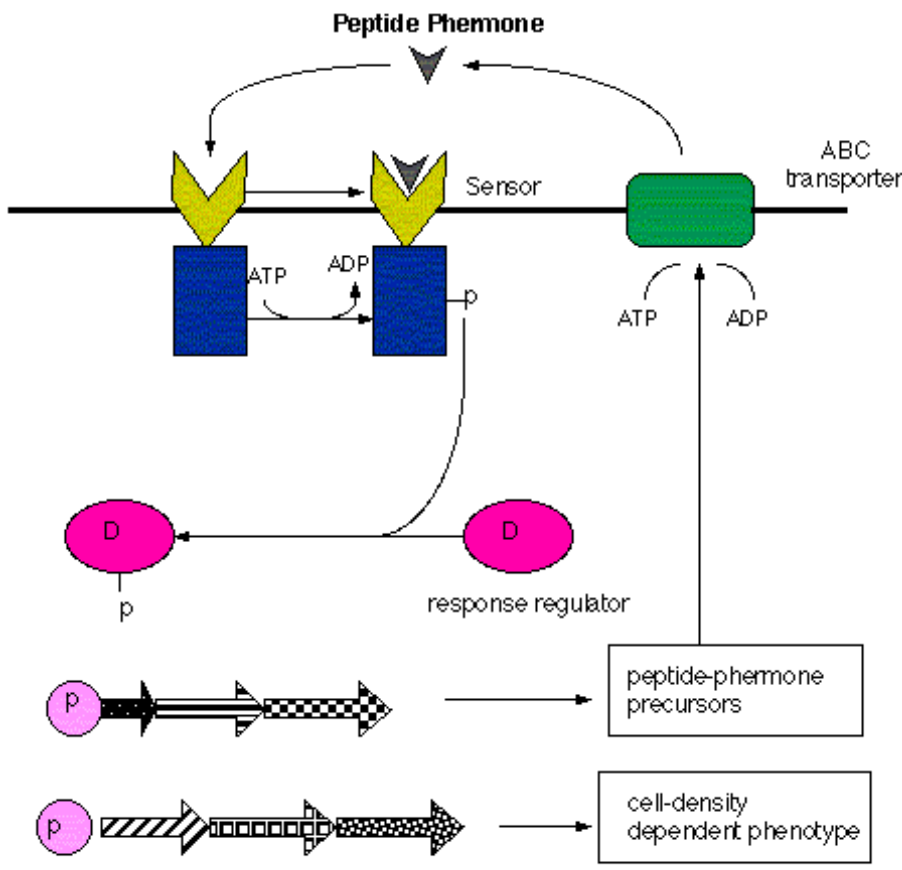

Regulated Gene Expression

Figure 5. QS mediated by peptides pheromones and two-component regulatory systems in Gram-positive bacteria. ${ }^{26}$

The autoinducing peptides AIP are the short oligopeptide fragments ${ }^{17}$ that are posttranslationally modified through the insertion of a lactone, thiolactone, lanthionine or isoprenyl group to yield diverse structures (Figure 6). They could differ in binding selectivities and activation in different Gram positive bacteria. 


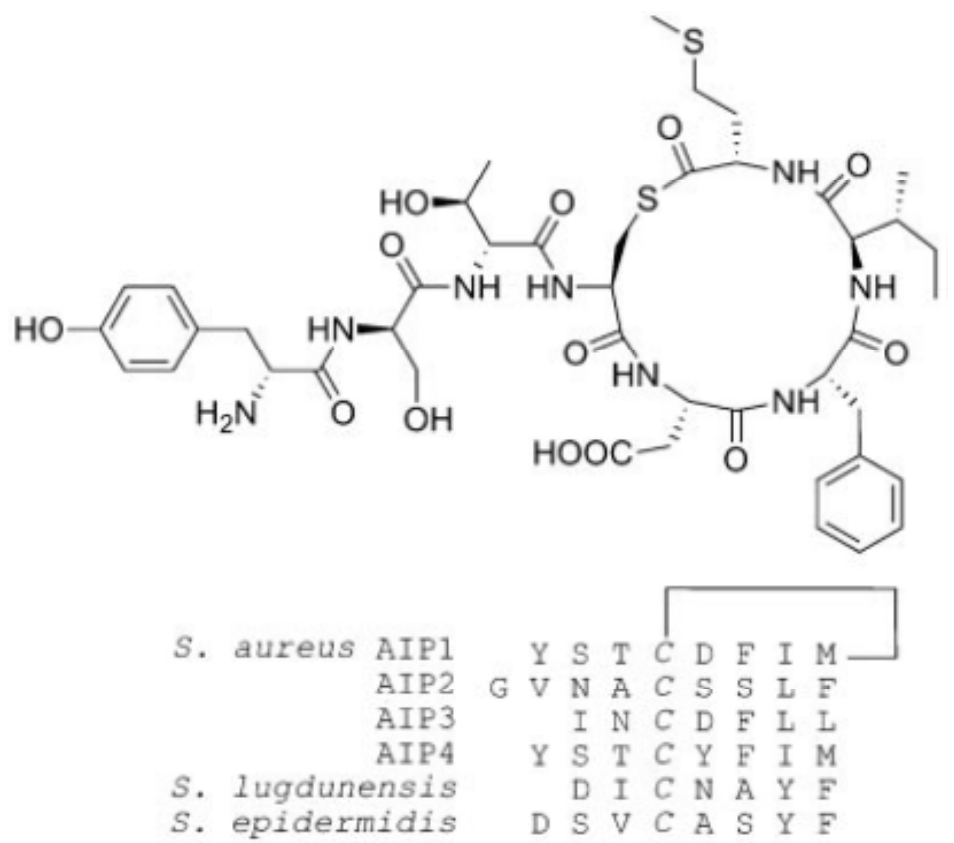

Figure 6. Structures of the selected AIPs. ${ }^{17}$

\subsubsection{Gram negative bacteria}

The mechanism of QS in Gram negative bacteria starts with the secretion of autoinducers or pheromones (AHL). When the inducer binds to the receptor, it activates the transcription of certain genes. As the population of bacteria grows a positive feedback is started. ${ }^{27}$ The AHL molecules are composed of fatty acyl chain linked to a lactonised homoserine through an amide bond. ${ }^{28}$ Different structures of AHLs which modulate different regulatory proteins in different bacteria are presented in Table 2. They are the subject of vast literature reports. ${ }^{17,29-41}$ Their structure and composition vary in the acyl chain and lead to different biochemical and physiological functions. ${ }^{17}$ 


\begin{tabular}{|c|c|c|c|}
\hline Organism & Signal & Regulatory proteins & Phenotype \\
\hline A.hydrophila & $\mathrm{C}_{4}$-HSL & Ahy1/AhyR & $\begin{array}{l}\text { Exoprotease } \\
\text { production }\end{array}$ \\
\hline A.salmonicida & $\mathrm{C}_{4} \cdot \mathrm{HSL}$ & AsaI/AsaR & $\begin{array}{l}\text { Extracellular } \\
\text { protease }\end{array}$ \\
\hline A.tumedaciens & 3-oxo- $\mathrm{C}_{8}$-HSL & TraI/TraR & $\begin{array}{l}\text { Ti plasmid } \\
\text { conjugation }\end{array}$ \\
\hline B.cepacia & $\mathrm{C}_{8} \mathrm{HSL}$ & CepI/CepR & $\begin{array}{c}\text { Protease } \\
\text { siderophores }\end{array}$ \\
\hline C.violaceum & $\mathrm{C}_{6}-\mathrm{HSL}$ & CviI/CviR & $\begin{array}{c}\text { Exoenzyme, } \\
\text { antibiotics }\end{array}$ \\
\hline E.carotovora & $\mathrm{C}_{6-\mathrm{HSL}}$ & ExpI/ExpR & $\begin{array}{c}\text { Exoenzyme, } \\
\text { carbapenem } \\
\text { antibiotic }\end{array}$ \\
\hline E. chrysanthemi & 3-oxo- $\mathrm{C}_{6-\mathrm{HSL}}$ & ExpI/ExpR & Pectate lyase \\
\hline P. aureofaciens & $\mathrm{C}_{6-\mathrm{HSL}}$ & $\mathrm{PhzI} / \mathrm{PhzR}$ & Phenazine antibiotics \\
\hline P. aeroginosa & 3-oxo- $\mathrm{C}_{12}$-HSL & $\begin{array}{l}\text { LasI/LasR } \\
\text { RhII/RhIr }\end{array}$ & $\begin{array}{c}\text { Multiple } \\
\text { extracellular } \\
\text { enzyme, biofilm } \\
\text { formation }\end{array}$ \\
\hline R.sphaeroides & $\mathrm{C}_{14-\mathrm{HSL}}$ & CerI/RhIR & $\begin{array}{c}\text { Dispersal from } \\
\text { bacterial aggregate }\end{array}$ \\
\hline S.liquefaciens & $\mathrm{C}_{4}$-HSL & SwrI/SwrR & $\begin{array}{c}\text { Extracellular } \\
\text { protease }\end{array}$ \\
\hline V.fischeri & $\mathrm{C}_{6}$-HSL & LuxI/LuxR & Bioluminescence \\
\hline V.harveyi & 3-hydroxy-C ${ }_{4}$-HSL & LuxM/N & Bioluminescence \\
\hline $\begin{array}{c}Y . \\
\text { pseudoruberculosis }\end{array}$ & $\mathrm{C}_{6-} \mathrm{HSL}$ & $\begin{array}{l}\text { YpsR/I } \\
\text { YthR/I }\end{array}$ & $\begin{array}{l}\text { Regulation of } \\
\text { clumping and } \\
\text { motility }\end{array}$ \\
\hline Y. pestis & $\mathrm{C}_{10-} \mathrm{HSL} / \mathrm{C}_{6}-\mathrm{HSL}$ & $\begin{array}{l}\text { YspI/YspR } \\
\text { YpeI/YspR }\end{array}$ & $\begin{array}{l}\text { Regulation of } \\
\text { clumping and } \\
\text { motility }\end{array}$ \\
\hline
\end{tabular}

Table 2. Representative AHLs and their function in Gram negative bacteria. ${ }^{17,29-41}$

The $N$-acyl-L-homoserine lactones (1, AHLs) are derived from S-adenosylmethionine (SAM, 3, Scheme 1) with the assistance of the enzymatic action of LuxI ${ }^{25,42}$ as shown in Scheme 1. Intramolecular cyclization of the homocysteine fragment with the elimination of the 5'-S-methyl-5'-thioadenosine and the concomitant acylation of the amino group with the common acyl carriers provided various AHL analogues. 
<smiles>CCC(N)C(=O)O</smiles>

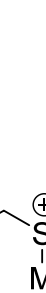<smiles>Nc1ncnc2[nH]cnc12</smiles><smiles>[NH]</smiles><smiles>C1CCOCC1</smiles><smiles>OC1C2CCC(O2)[C@H]1O</smiles>

$\stackrel{\text { Acyl-acyl carrier protein }}{\longrightarrow}$<smiles>[R]C(=O)CC(=O)SC1CC1</smiles>

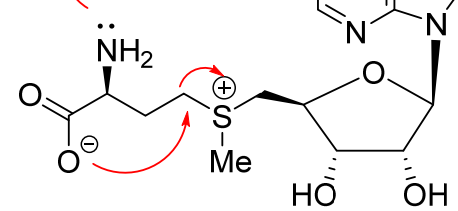
SAM 3<smiles></smiles>

5'-S-Me-Adenosine<smiles>CC(C)(C)[Al]</smiles><smiles>[R]C(=O)CC(=O)NC1CCOC1=O</smiles>

$\mathrm{N}$-acyl-L-homoserine lactone

\section{Scheme 1. Biosynthesis of $N$-(acyl)-L-homoserine lactone. ${ }^{25}$}

The mechanism of action of AHL QS starts with the diffusion of the latter in the cell (Figure 7). The interaction with the LuxR-type protein leads to acyl-HSL bond formation. It is divided into two domains: first, the conserved one which includes the $\mathrm{N}$ terminal of LuxR from acyl-HSL-binding region; second, the C-terminus with a helixturn-helix motif $(\mathrm{HTH})$ required for DNA binding. The binding between $N$-terminal and acyl-HSL leads to conformation changes followed by a DNA binding. ${ }^{17}$

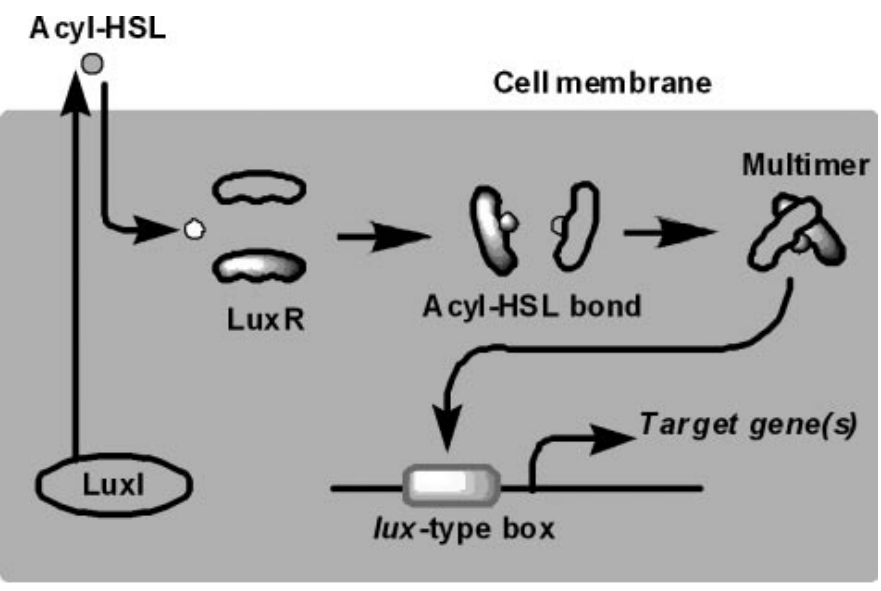

Figure 7. AHL quorum sensing mechanism. ${ }^{17}$ 
E. coli and S. typhimurium are common causes of food-bourne illness. ${ }^{43}$ They are believed to have homologous QS pathways. ${ }^{44}$ In solution, DPD undergoes rapid cyclisation (see below Scheme 4) and exists in equilibrium with several different isoforms. Thus AI-2 is not a specific molecular structure but a family of isomers. ${ }^{45}$ The recruitment of boron is needed for the case of $V$. harveyi.$^{18}$ As shown in Figure 8a below, the AI-2 QS process in both E. coli and S. typhimurium is regulated by the same LuxSregulated operon $(l s r)$. After DPD cyclizes to form AI-2, it gets exported extracellularly where it accumulates. Once a threshold is reached, the bacterial QS is initiated and signal transduction is activated. AI-2 is imported by $l s r$ inside the cell, via $l s r$ transporter, ${ }^{46}$ where it gets phosphorylated by kinase to form phospho-AI-2. This form allows it to bind to LsrR known as a repressor which effects it to be released. A positive feedback is used causing increased expression of the transporter and resulting in more importation of AI-2.

In case of $V$. harveyi and $V$. cholerae ${ }^{47}$ (Figure $8 \mathrm{~b}$ ), the three cognate receptors CqsS (mediated by CAI-1) ${ }^{48}$ LuxN (mediated by AI-1) and LuxQ (which interacts with the complex LuxP-AI-2) are membrane-bound histidine sensor kinases. ${ }^{49}$ The sensory mechanism is a two-component regulatory path that produces LuxR. ${ }^{50-53}$ The role of LuxR is to control the expression of bioluminescence related genes. At low concentrations, the cognate receptors act as kinases and lead to the formation of phosphor-LuxO and then the synthesis of sRNA that leads to the degradation of luxR mRNA. At high concentrations, the cognates switch from kinases to phosphorylases and remove phosphate from LuxO to LuxU which permits translation of luxR mRNA to LuxR and expression of bioluminescence. ${ }^{4}$ 


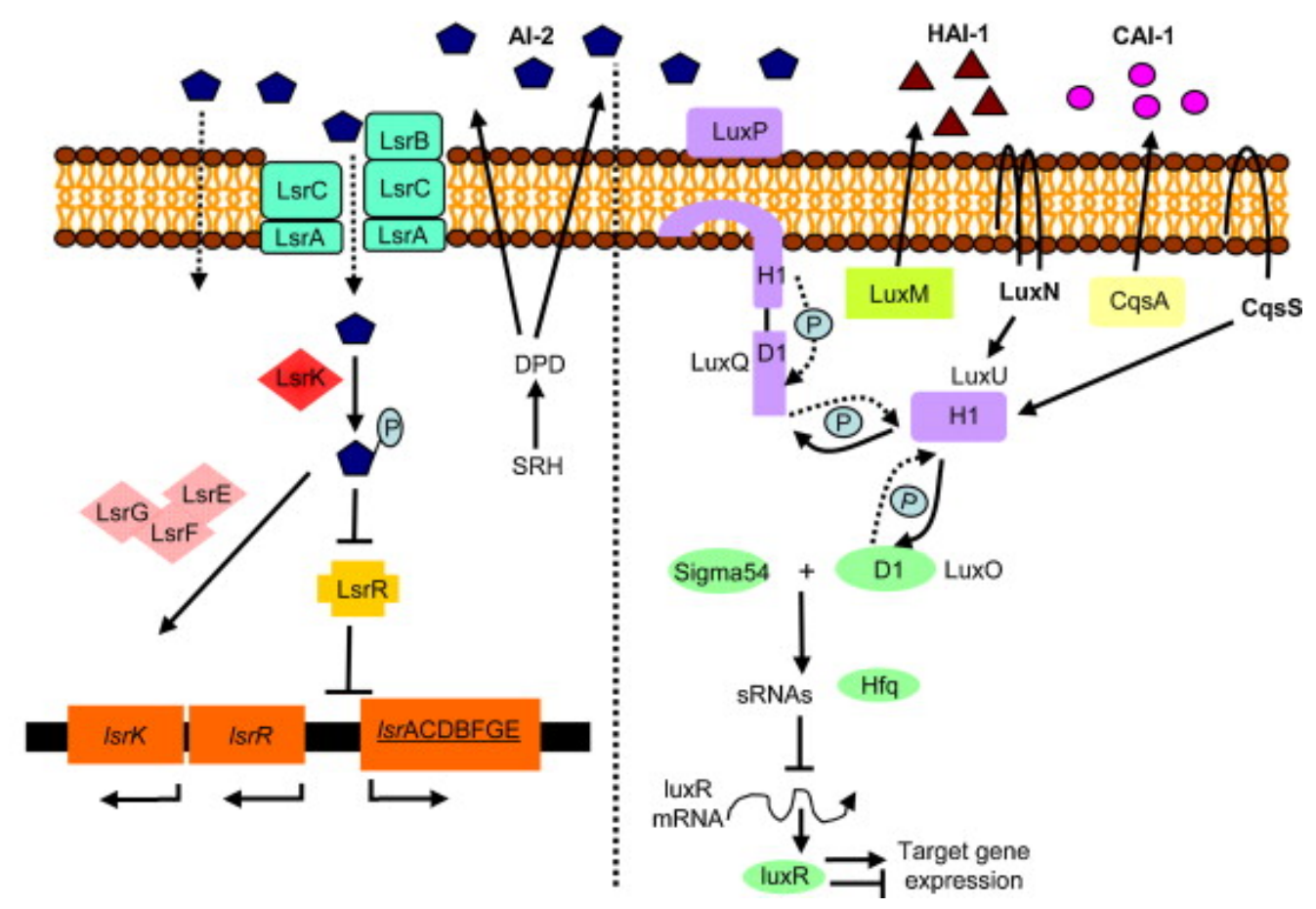

Figure 8. Quorum sensing pathways in $E$. coli and $S$. typhimurium and $V$. harveyi. ${ }^{18}$

An important example of Gram negative bacteria is Pseudomonas aeroginosa, capable of infecting insects, plants, animals and humans. As an opportunistic pathogen, it colonizes immunocompromised hosts. ${ }^{54,55}$ It is most prominent in patients with cystic fibrosis (a common lethal, genetic disease where the patient often dies because of impaired lung function). A key factor that contributes to the pathogenesis of $P$. aeroginosa and antibiotic resistance is its ability to form a biofilm that attaches either to an interface or to each other, inhabit an extracellular polymeric matrix and exhibit a phenotype distinct from the planktonic cells in terms of gene expression, growth and protein production. ${ }^{56}$

P. aeruginosa is unique from the other pathogens described here since it does not make its own AI-2. ${ }^{16}$ P. aeruginosa utilizes two LuxI/R systems: LasI/R and RhII/R, 
which work in coordination to control the expression of various QS associated virulence factors $^{57}$ (Figure 9). Both LasI and RhII produce different AHL autoinducers, $\underline{N}-(3-$ oxododecanoyl)-HSL (OdDHL) and N-butyryl-HSL (BHL), respectively. ${ }^{58}$ Once activated by OdDHL, LasR boosts the expression of the $r h l$ regulon through $m v f R$, which causes a subsequent increase in 4-hydroxy-2-heptylquinoline (HHQ, Figure 3) and Pseudomomas quinoline signal (PQS, Figure 3) production. The PQS signal is released through the extracellular membrane due to its hydrophobic properties, whereas HHQ stays intracellular. By regulating $r h l$ and $m v f R$, LasR controls the production of the virulence factors and biofilm formation. ${ }^{59} P$. aeruginosa QS is capable of sensing both AHL signaling and $\mathrm{AI}-2 .^{16}$

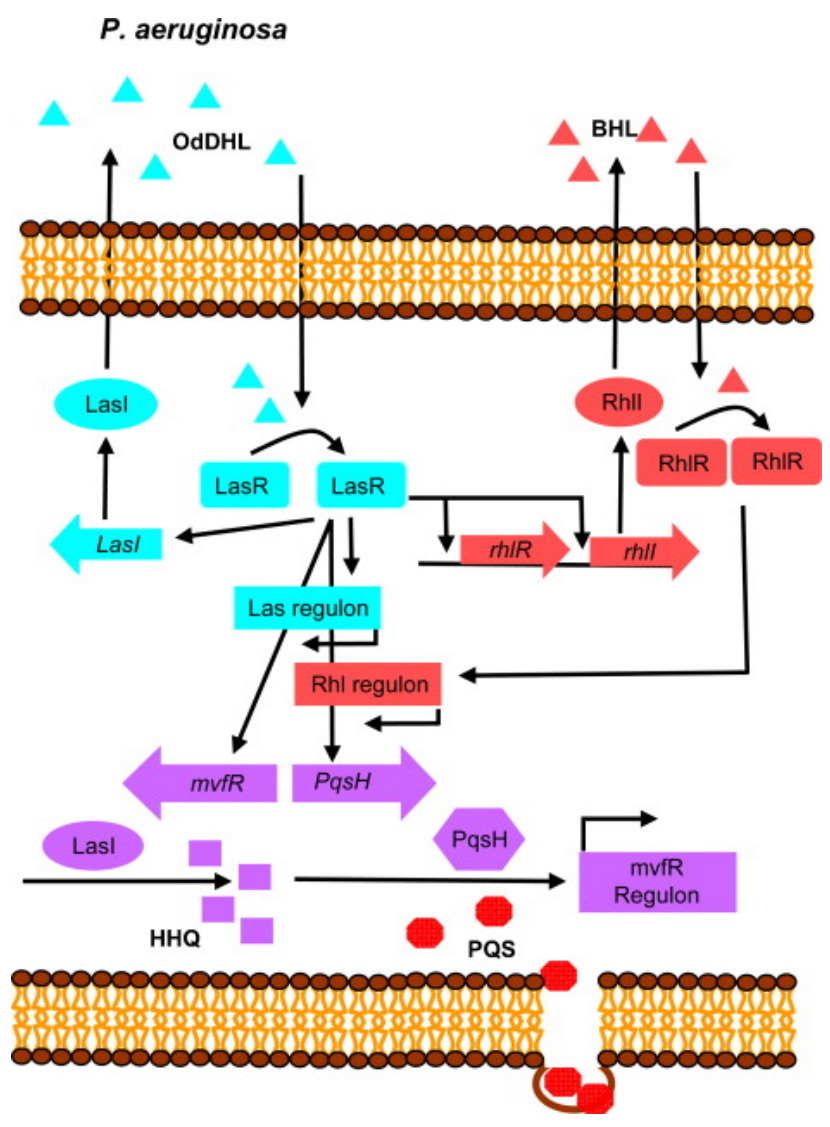

Figure 9. Quorum sensing circuit in P. aeruginosa. ${ }^{18}$ 


\subsubsection{Interspecies quorum sensing}

\subsubsection{S-Ribosylhomocysteinase (LuxS): Structure and functions}

LuxS is a small metalloenzyme containing $\mathrm{Fe}^{2+}$ ion tetrahedrally coordinated by His54 and His-58, Cys-126 and a water molecule. A highly conserved Cys-84 is located 4.86 $\AA$ from the metal ion. It is widely preserved among Gram negative and Gram positive bacteria. $^{60-64}$ The structure determination of LuxS protein revealed an $\alpha$ and $\beta$ fold ${ }^{64}$ featuring a four-stranded $\beta$-sheet partially surrounded by five helices. The $\beta$-sheet is composed of sheets $1,2,4,3$ and a $3_{10}$ helix. Helix $\alpha 1$ is adjacent to $\beta 1$ and $\beta 3$. Helices $\alpha 2,3$ and 4 are perpendicular to $\alpha 1$ (Figure 10A). Crystal structure of the protein revealed that LuxS is a homodimer with the subunits related by crystallographic symmetry. The central part is a dimeric interface that consists of $\beta$-sheets coming from each monomer. ${ }^{64}$ The dimeric interface has an extensive surface burying $2,125 \AA^{2}$ of solvent-accessible area per monomer compared to $1,685 \AA^{2}$ as a mean surface for other dimers. ${ }^{65}$ In Figure 10B, the letters A and B designate the two chains of the dimer of LuxS. 

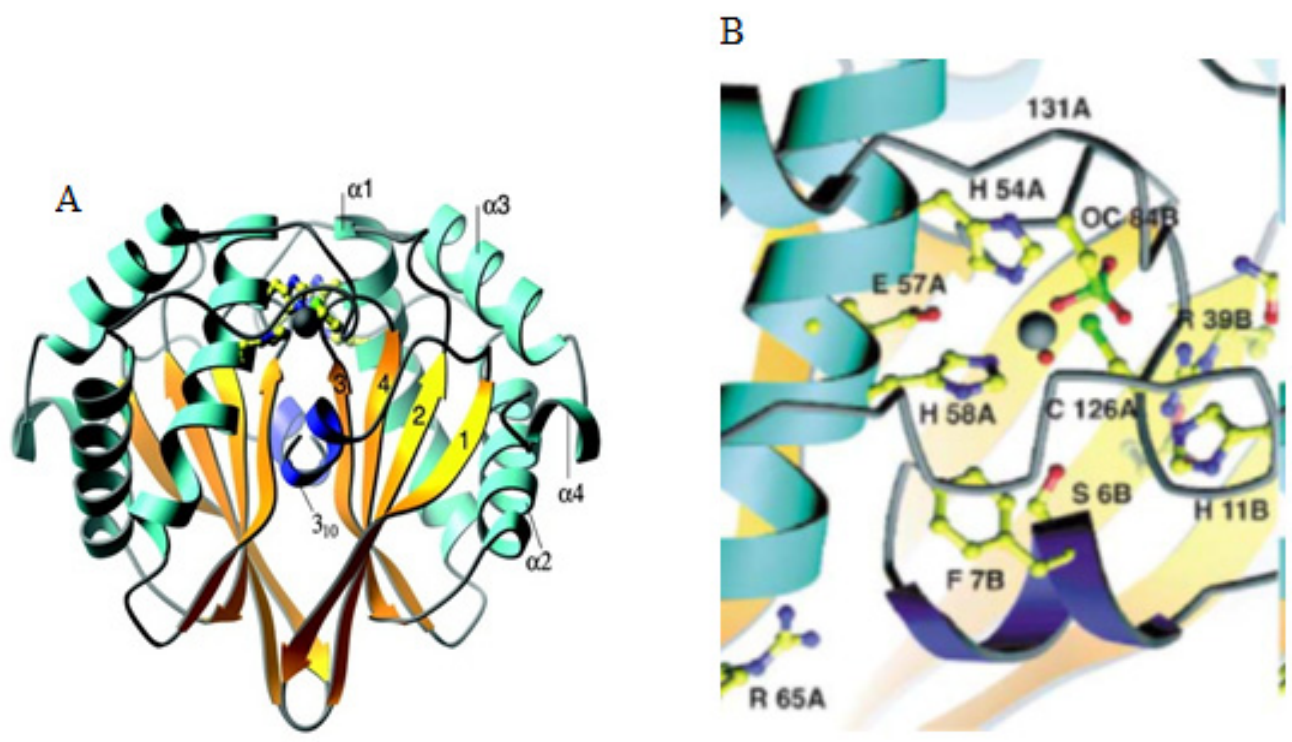

Figure 10. (A) Crystal structure of $\operatorname{LuxS}^{64}$; (B) A stereoview of the active site of LuxS. $^{66}$

LuxS mechanism of catalysis

The formation of AI-2 (2) starts with S-adenosyl-L-homocysteine (3a, SAH, Scheme 2) which is a product of S-adenosyl L-methionine (3, SAM)-dependent methylation. The hydrolysis of SAH by 5'-methylthioadenosine nucleosidase (MTAN) leads to adenine molecule and S-ribosyl-L-homocysteine (4, SRH). Afterwards, The SRH is cleaved by LuxS enzyme into L-homocysteine (Hcy) and 4,5-dihydroxy-2,3-pentanedione (DPD) which is the precursor of AI-2 ${ }^{1}$ (2, Scheme 2). The formation of AI-2 molecule is the result of a straightforward path that involves DPD (5) and boronic acid. The cyclization of DPD was shown to be thermodynamically favorable leading to the tetrahydrofuranone derivative pro-AI-2 (see also Scheme 5) that will complex with boronic acid to form the cyclic borate diester (AI-2). 

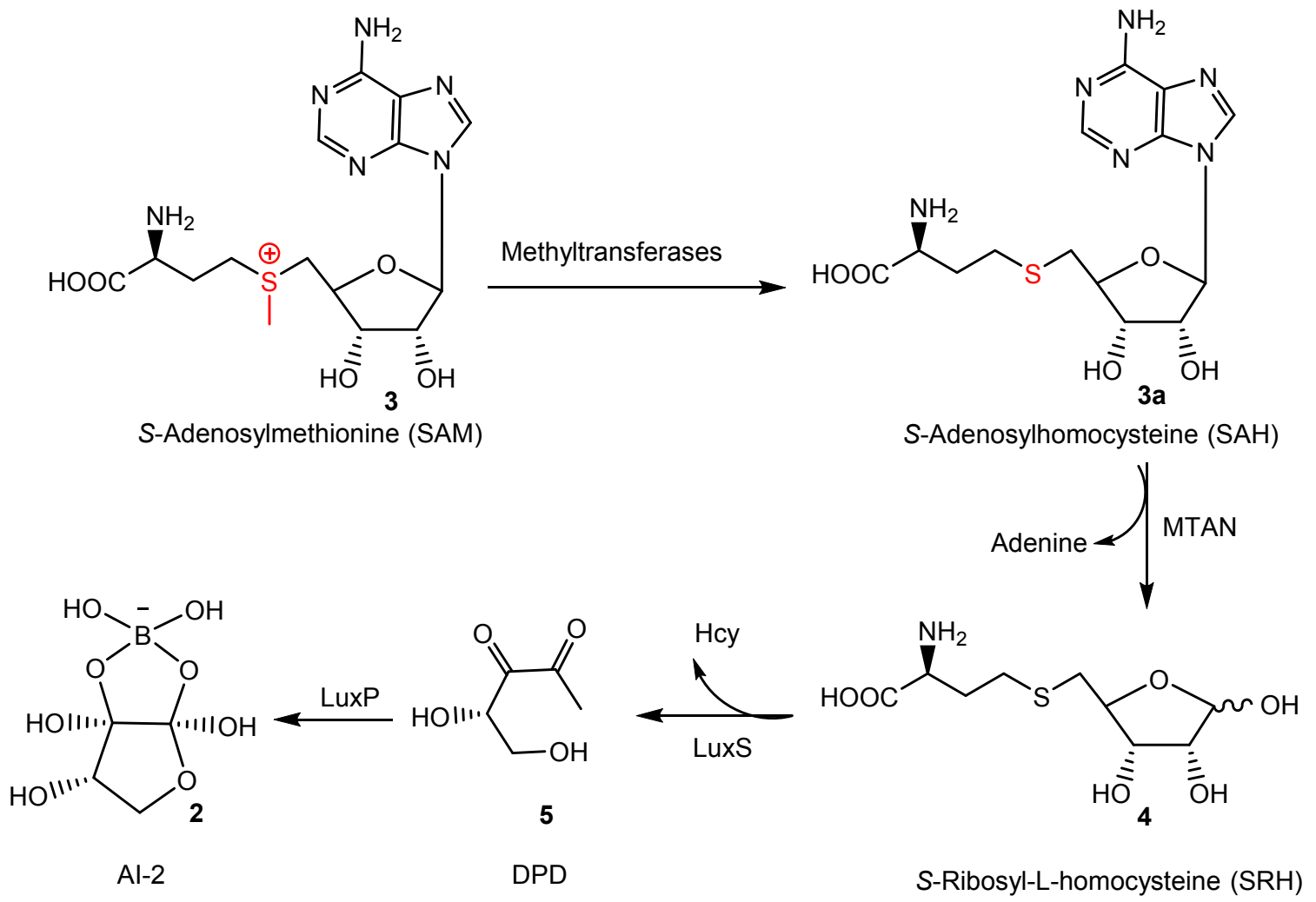

\section{Scheme 2. Pathway for the conversion of SAM to AI. ${ }^{18}$}

Pei and coworkers in 2003 proposed the pathway for the catalytic mechanism of $S$ ribosylhomocysteine ${ }^{61,67}$ presented in Scheme 3. Based on the kinetic, spectroscopic and labeling experiments they proposed that in the first initial step, coordination between the metal in LuxS and a water molecule occurs, making the newly formed open sugar complex $\mathbf{6}$ act as a Lewis acid. The acidic proton at $\mathrm{C} 2$ position in SRH complex $\mathbf{6}$ is then abstracted by the basic Cys- 84 present at the $\beta$-face of the SRH substrate at the active site of LuxS. The formed enediolate 7 undergoes ligand exchange with the $\mathrm{C} 2-\mathrm{OH}$ group assisted by a Glu57. Tautomerisation to keto form generates a carbonyl at C2 position (8). The repetition of this enolization-tautomerization step leads to the formation of the 3keto SRH complex $(\mathbf{9})$, which is prone to a $\beta$-elimination $(\mathbf{1 0} \rightarrow \mathbf{1 1})$ of homocysteine catalyzed by Glu57. The release of the homocysteine as a free thiol molecule occurs 
simultaneously with the formation of DPD in its enol form which will immediately tautomerize into the more stable keto form (5). DPD will then undergo cyclization to form a tetrahydrofuranone derivative (5a) which upon further complexation with boronic acid will lead to the formation of borate complex AI-2. Therefore, LuxS enzyme catalysis can be divided into three main steps: First the migration of carbonyl group from $\mathrm{C} 1$ to $\mathrm{C} 2$ position, then the shift of the carbonyl to $\mathrm{C} 3$ position and finally the $\beta$-elimination Hcy and formation of DPD.
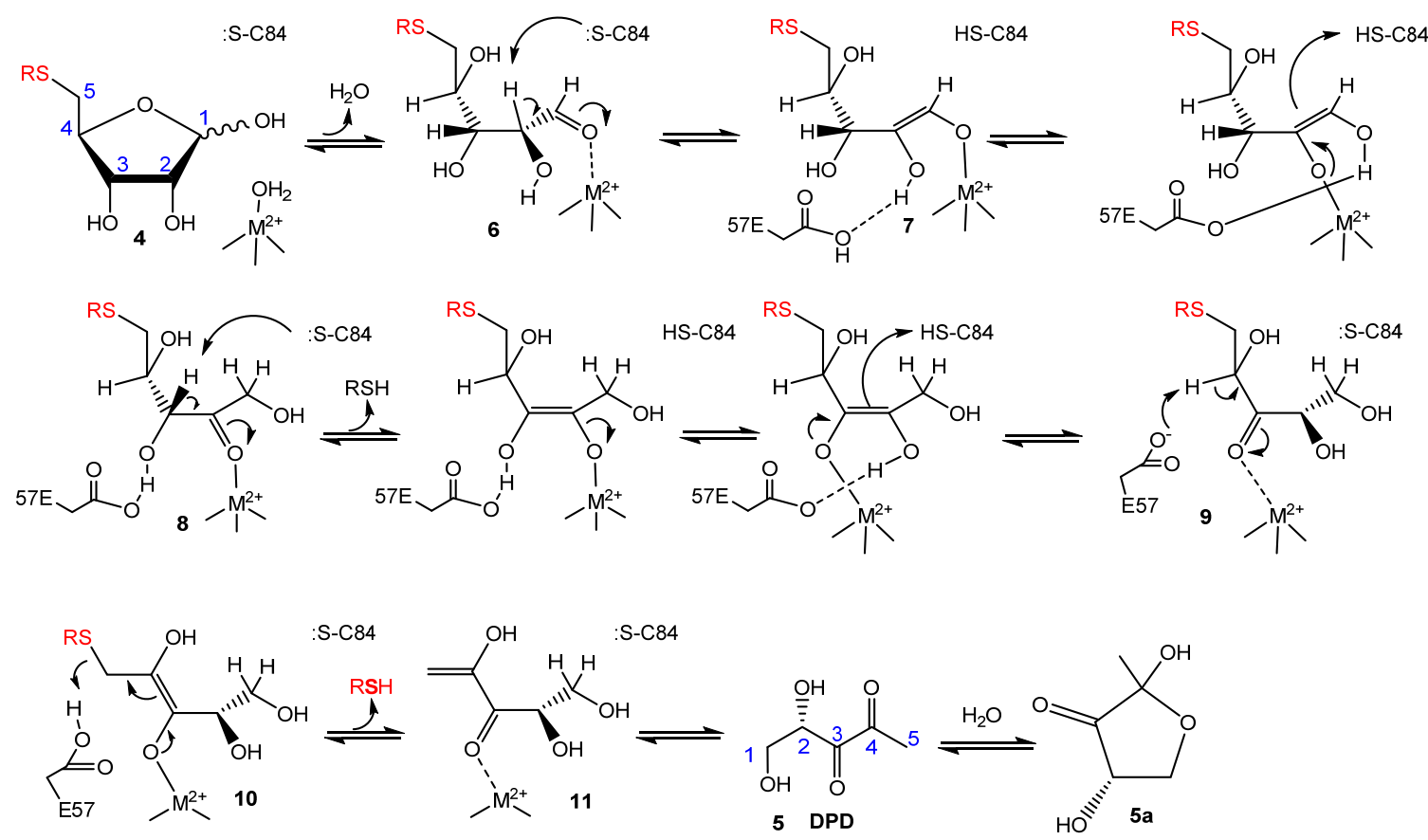

Scheme 3. Proposed mechanism of LuxS- catalyzed reaction. ${ }^{60,61}$

\subsubsection{The signaling pathway of autoinducer-2 (AI-2)}

Structure of AI-2.

AI-2 (2) is the universal signal molecule ${ }^{68-70}$ generated by LuxS synthase enzyme. Due to the fact that the differentiation in AI-2 signaling occurs at the transduction level, 
different bacteria respond to AI-2 differently. The structure of AI-2 contains two fused five-membered rings located within the LuxP binding site. The hydrogen binding network is the main cause that stabilizes AI-2 molecule in the binding site (Figure 11). AI-2 interacts with different amino acids, the two arginines 215 and 310 present in the active site which are the positively charged residues that form hydrogen bonding with three borate oxygens in AI-2 and therefore stabilize the negative charge of the borate.

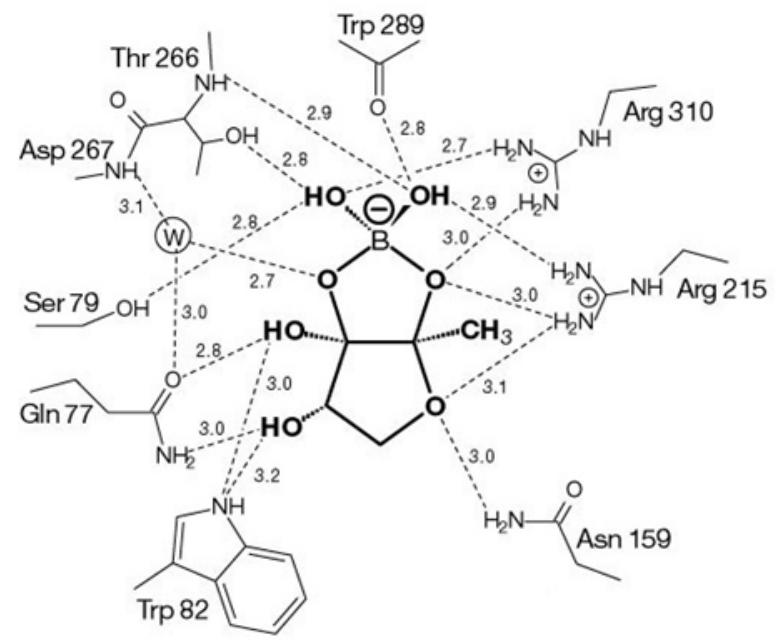

Figure 11. Interaction of the furanosyl borate diester (AI-2) with the amino acids at the binding site. ${ }^{1}$

AI-2: A common language among bacteria:

Unlike other autoinducers, AI-2 does not resemble any other signaling molecules. ${ }^{42}$ It is proposed to serve as a universal signal for inter-species communication (Figure 12). It includes a group of signal molecules formed from a common precursor 4,5-dihydroxy2,3-pentanedione (DPD) (5 ; Scheme 2). In its turn, DPD is a bacterial by-product of the activated methyl cycle in a reaction catalyzed by LuxS. $^{71}$ In a co-culture, the E. coli produces AI-2, which is sensed by S. typhimurium. 


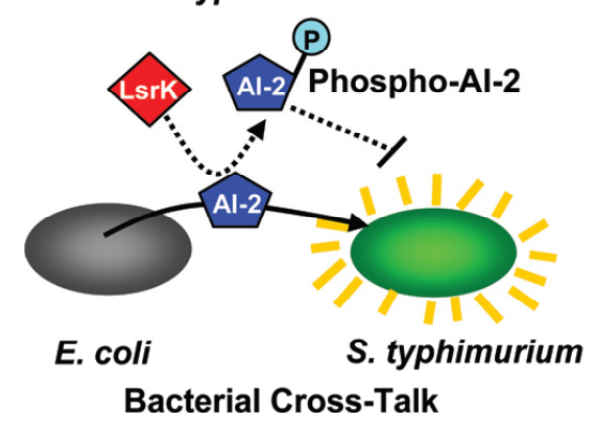

Figure 12. Bacterial cross-talk through AI-2 ${ }^{42}$

The crystal structure of AI-2 (Figure 13) in complex with its required signaling partner, LuxP, was revealed by Bassler and coworkers ${ }^{72}$ containing the furanosyl borate diester.

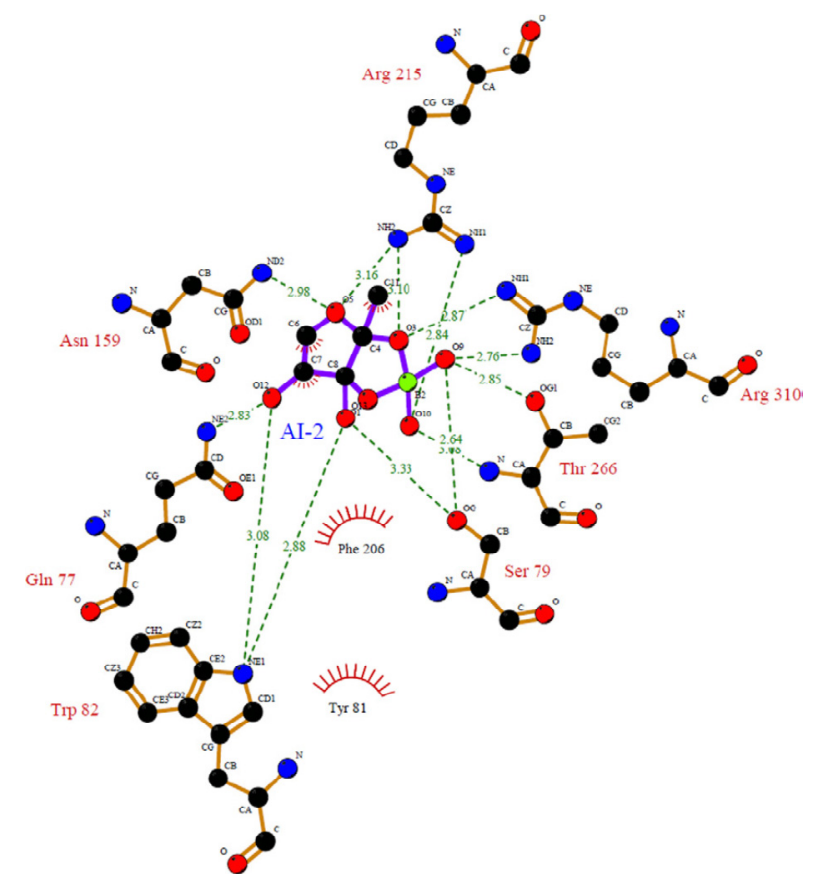

Figure 13. A schematic illustration of AI-2 with LuxP. ${ }^{1}$

To date, two classes of AI-2 specific receptors have been identified: LuxP family found in vibrio $s p$. and the LsrB family identified in S. Typhimurium. ${ }^{3}$ Miller et al. ${ }^{73}$ identified a non-borated enantiomer of DPD $(2 R, 4 S)$-2-methyl-2,3,3,4tetrahydroxytetrahydrofuran-borate, $R$-THMF, Scheme 4) ligand in a crystal structure of 
an AI-2 receptor $L s r B$ from the Salmonella enterica species. These studies demonstrated that bacteria have the ability to detect different molecules based on the stereochemical assignment including differentiation of enantiomers.

\section{Formation of DPD:}

AI-2 is a collective name for a group of signaling molecules formed from 4,5dihydroxy-2,3-pentanedione (DPD, 5)..$^{44,71,74-76}$ DPD is an enigmatic molecule that has been known since 1971 as a bacterial byproduct ${ }^{45}$ of the activated methyl cycle in a reaction catalyzed by LuxS. $^{71}$ DPD is the product of the cleavage of $S$ ribosylhomocysteine (SRH) (Scheme 3) which spontaneously cyclizes into furanone derivatives (Scheme 4): (2S,4S)-2-methyl-2,3,3,4-tetrahydroxytetrahydrofuran-borate ( $S$ THMF-borate) and (2R,4S)-2-methyl-2,3,3,4-tetrahydroxytetrahydrofuran-borate (RTHMF) which are known by specific periplasmic binding proteins in $V$. harveyi and $S$. enterica respectively. ${ }^{1,73}$ DPD can be also synthesized from ribulose-5-phosphate and although this pathway is not clinically significant it has been proved to be an important metabolic passageway for DPD. ${ }^{77,78}$ DPD has recently been synthesized ${ }^{45,79}$ by Semmelhack and Meijler and their coworkers. It exists in an equilibrium mixture of two cyclic tetrahydrofuranone isomers: $\quad S$-DHMF $\quad((2 S, 4 S)$-2-methyl-2,4dihydroxytetrahydrofuranone $) \quad$ and $\quad R$-DHMF $\quad((2 R, 4 S)$-2-methyl-2,4dihydroxytetrahydrofuranone) (Scheme 4) with the respective hydrated analogues $S$ THMF and $R$-THMF. When complexed to boronic acid, only the $S$-DHMF forms $S$ THMF-borate known as AI-2 ${ }^{1}$ (2, Scheme $\left.\mathbf{2}\right)$. 


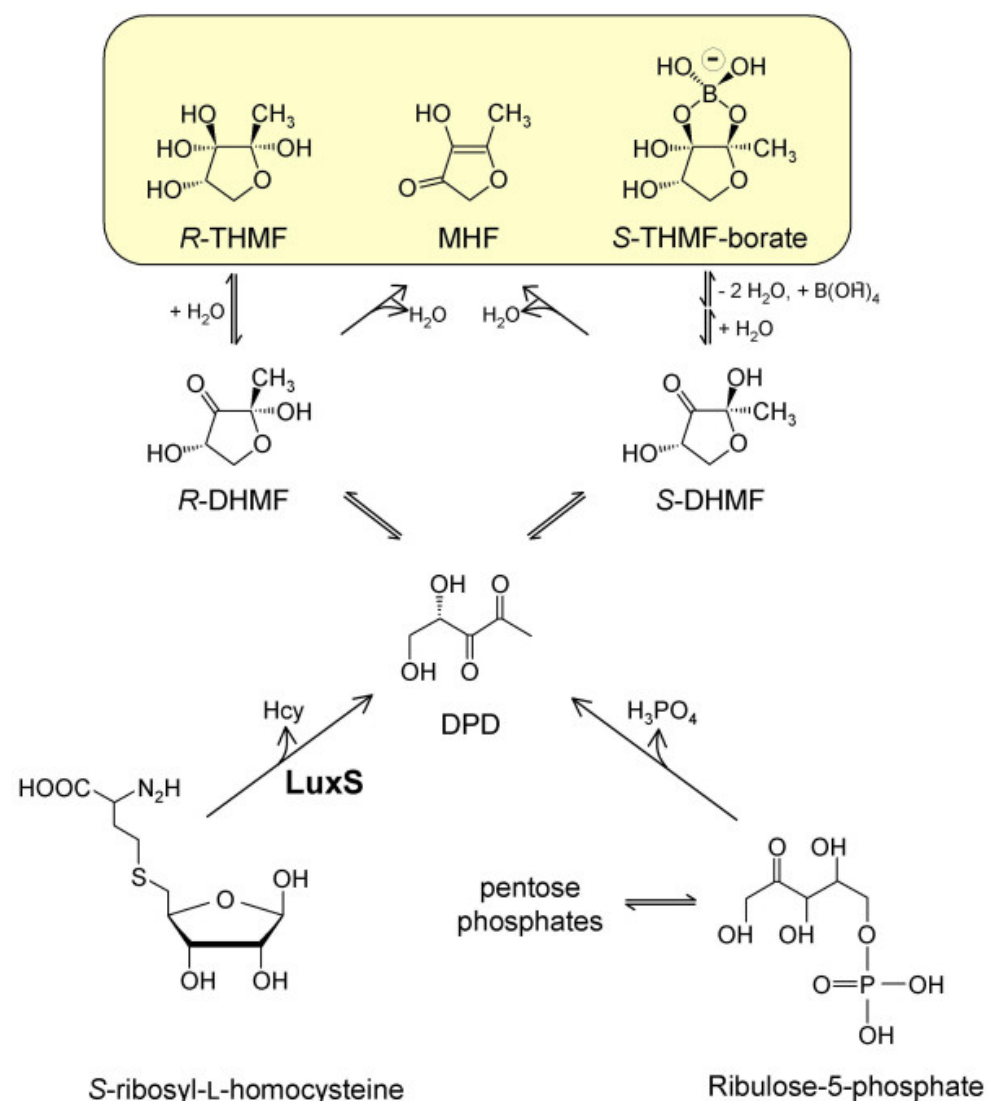

\section{Scheme 4. Biosynthetic pathways for the formation of DPD and AI-2. ${ }^{3}$}

DPD undergoes spontaneously cyclization to the corresponding tetrahydrofuranose derivative known as pro-AI-2. Hydration reactions in solution produced $R$-THMF diastereoisomers. In the presence of Boronic acid, the $S$-THMF undergoes complexation to form $S$-THMF-borate known as AI-2 (Scheme 5).

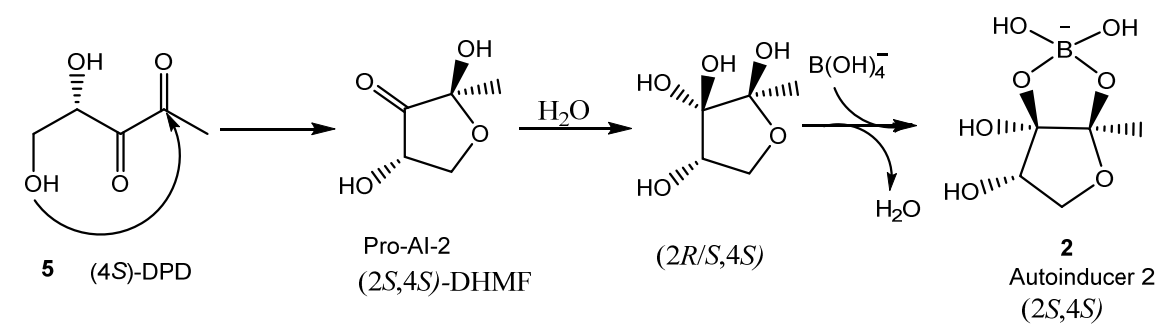

Scheme 5. Cyclization pathway of DPD to AI-2. ${ }^{80}$ 


\subsubsection{Strategies for quorum quenching (QQ)}

The disturbance of quorum sensing should reduce pathogenicity. ${ }^{5,81}$ The approach of interfering with or destroying the QS signal is referred to as Quorum quenching (QQ). Strategies for quorum quenching include competing with the native signaling process either by creating signal molecules analogs, limiting signal generation or destroying the native molecules by sequestering traps. Organization of the quorum quenching is based on the location of the quenching in the track. It could either occur at the signal generator, the signal itself or the signal receptor and transducer (Figure 14). Currently there are three models being followed for the development of QQ agents. First, inhibition of QSSM synthase, for example LuxS in case of AI-2 QS $^{82-84}$ or LuxI type in case of AHLbased systems. ${ }^{85}$ Second, neutralization of QSSM by protein based strategies as QSSM degrading enzyme ${ }^{86}$ or sequestrating antibodies. ${ }^{87-89}$ Third, imitation of the ligand at the receptor level through QSSM analogs. ${ }^{56,90-92}$ Other strategies have been employed including inhibition of the signal secretion ${ }^{93,94}$ or interference with the downstream signal. $^{95}$ 


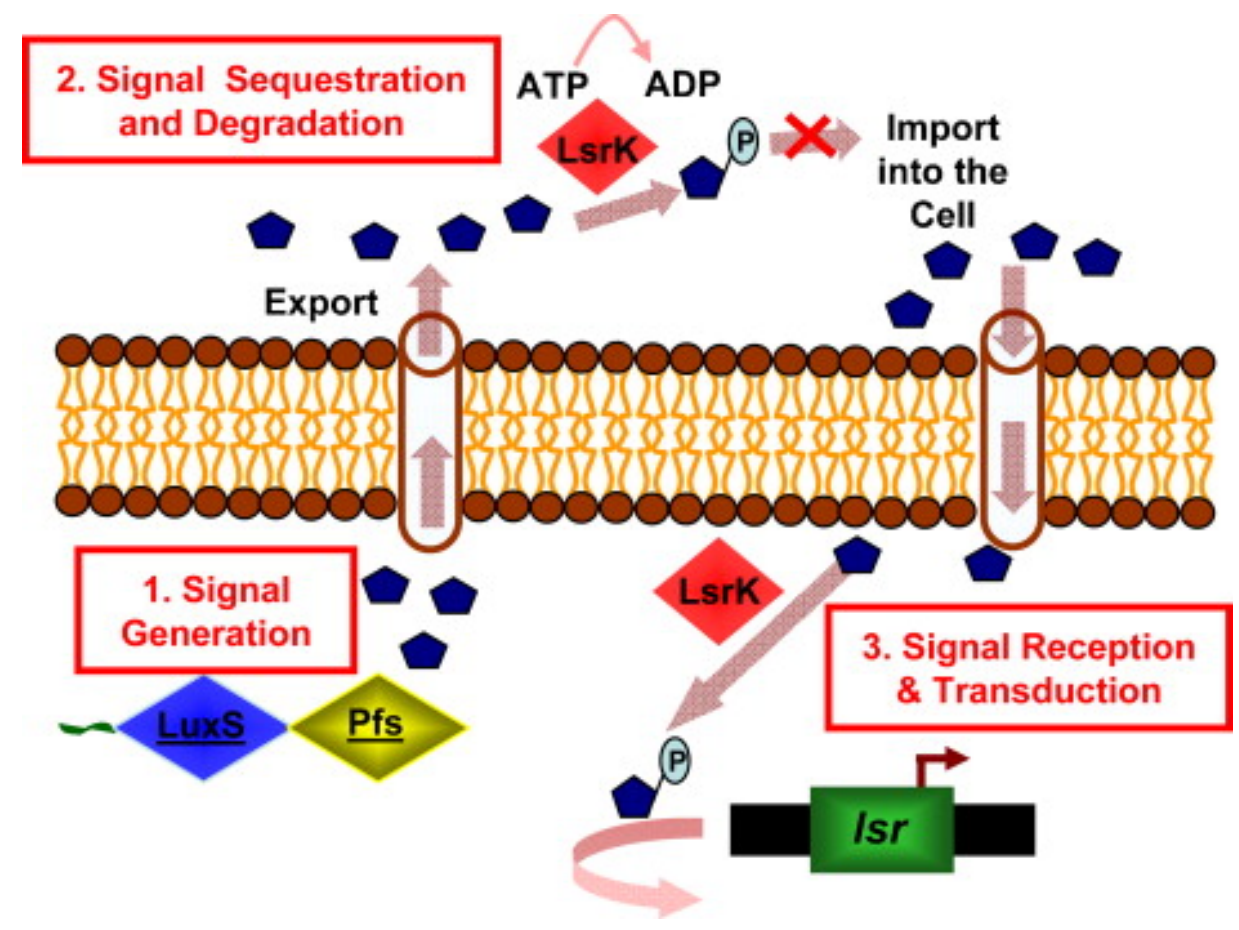

Figure 14. Strategies for quorum quenching. ${ }^{18}$

The QS mechanism in E. coli consists of various luxS regulated $l s r$ genes. ${ }^{46}$ Signal transduction by $l s r$ gene expression, characterizes the native AI-2 QS response (Figure 15a). By binding to the transcriptional repressor LsrR, phospho-AI-2 induces transcription of the $l s r$ genes. Roy and coworkers, ${ }^{42}$ tried to quench the cross communication among different bacteria (Figure 15b) using LsrK, an enzyme that phosphorylates AI-2 upon uptake into the cell, using ATP. LsrK and ATP are delivered outside the cell and phosphorylation of AI-2 leads to the unstable phosphor-AI-2 that auto-degrades to 2-phosphoglycolic acid (PG) overnight, which is then prevented from being carried into the cells. They demonstrated that when LsrK and ATP where added exvivo to bacteria, the native QS response significantly diminished. 

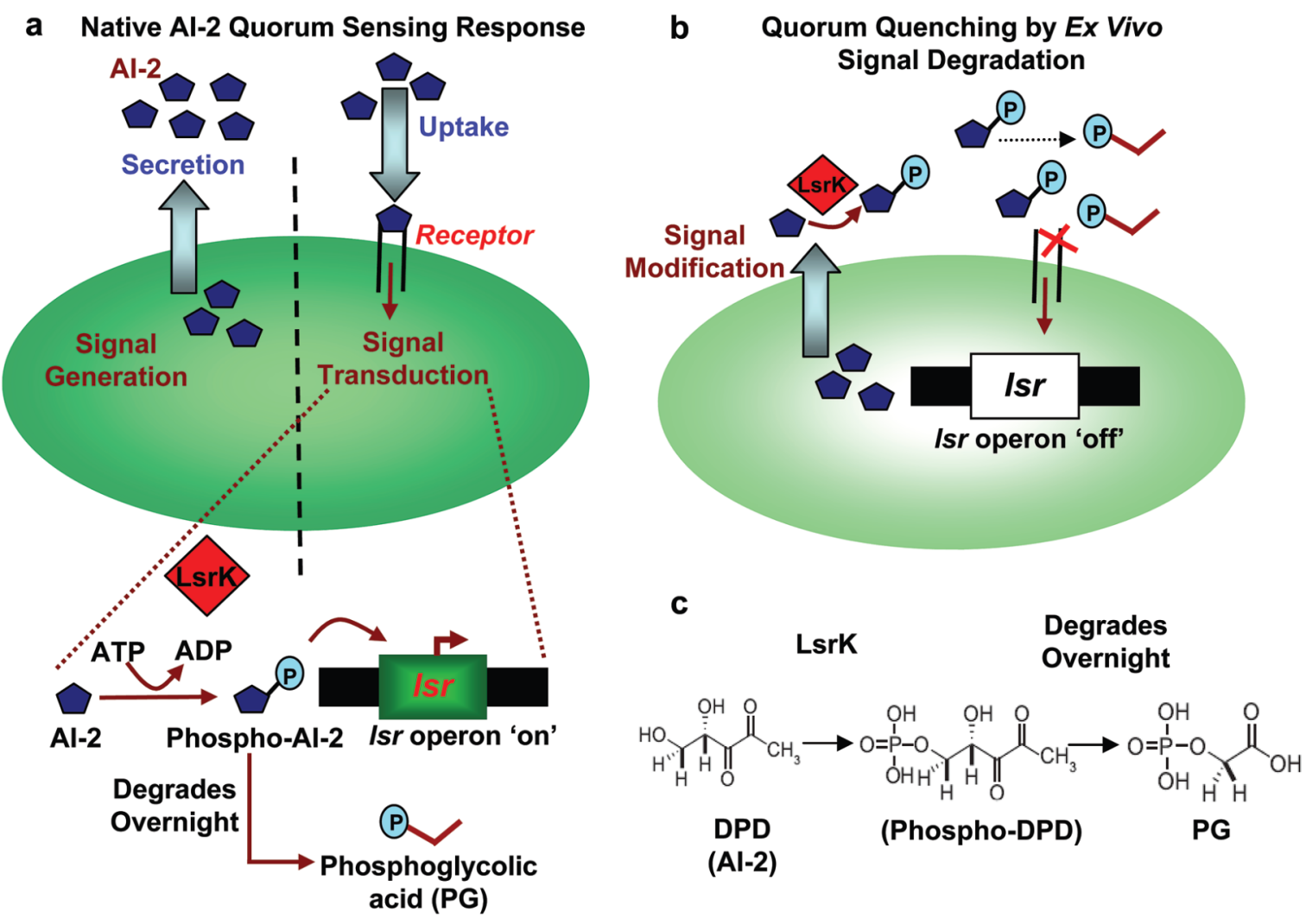

Figure 15. Schematic LsrK-mediated quenching. ${ }^{42}$

\subsection{Dimerisation inhibition}

LuxS enzyme is a metalloenzyme with a symmetrical dimer structure that catalyzes the non-redox cleavage of the stable thioether bond in SAM cycle with no need of NADH cofactor for the chemical reaction. ${ }^{60}$ Introducing a dimer inhibitor molecule to LuxS might be considered as a new strategy for the inhibition of the LuxS enzyme which has not been studied before. Some other dimer inhibitors that have been designed in litterature act on different dimer enzymes. Examples of dimer inhibitors include Herceptin ${ }^{\circledR}{ }^{96}$ (Trastuzumab) and TSAO-T. ${ }^{97}$ 


\subsubsection{Examples of dimer inhibitors of other enzymes}

Since many enzymes are homodimers or multimers, the disturbance of the stereochemical orientation between protein subunits offers another rational way for enzyme inhibition leading the ability to alter the function of the enzyme. ${ }^{65}$ One important example would be Trastuzumab, a new anticancer agent (monoclonal antibody) that binds to the juxtamembrane region of the human epidermal growth factor receptor 2 known as HER 2. Trastuzumab deactivates the kinase, providing a steric barrier to the interaction of the transmembrane region and consequently disrupts HER 2 interactions with the protein. ${ }^{96}$ Also, a thymidine nucleoside analogue modified at the $\mathrm{C} 3$ position with a spiro sulfonate ring belonging to TSAO family (12, Figure 16), which is a part of the nonnucleoside reverse-transcriptase inhibitors known as NNRTI, is used as a selective inhibitor against HIV-1 virus, by binding to the p66/p51 dimer subunit interface. ${ }^{98}$

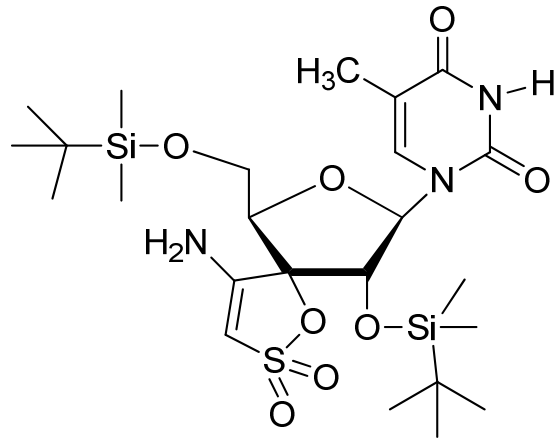

12

Figure 16. TSAO-T, selective inhibitor of HIV-1.99

\subsubsection{Dimerization process in LuxS enzyme}

LuxS enzyme is a small $(35 \mathrm{kDa})$ homodimeric protein. ${ }^{100}$ In theory, SRH is positioned in between the two monomers at the active site of LuxS. The stereoview of the atomic interactions between LuxS and the 2-ketone intermediate reveals that the subunit 
A of the dimer has the metal ion of the active site (in gold color in Figure 17), whereas the subunit $\mathrm{B}$ atoms shown in cyan color, ${ }^{101}$ hold the catalytic residue Cys84 and contribute less to the substrate binding residues (Notice that the oxygen atom of the 2ketone position of the intermediate is coordinated to the cobalt ion. Also the Ala- 84 of the Cys-84-ala LuxS protein is positioned near the $\mathrm{C} 2$ and $\mathrm{C} 3$ atoms). Thus, the insertion of a dimer inhibitor in between the two monomers would theoretically prevent their interactions. The lack of coordination between subunits A and B should lead to the inactivation of the LuxS enzyme, since the catalytic role of subunit B which includes the cleavage of SRH to DPD would not be associated with subunit A due to the steric insertion between the two subunits. ${ }^{101}$

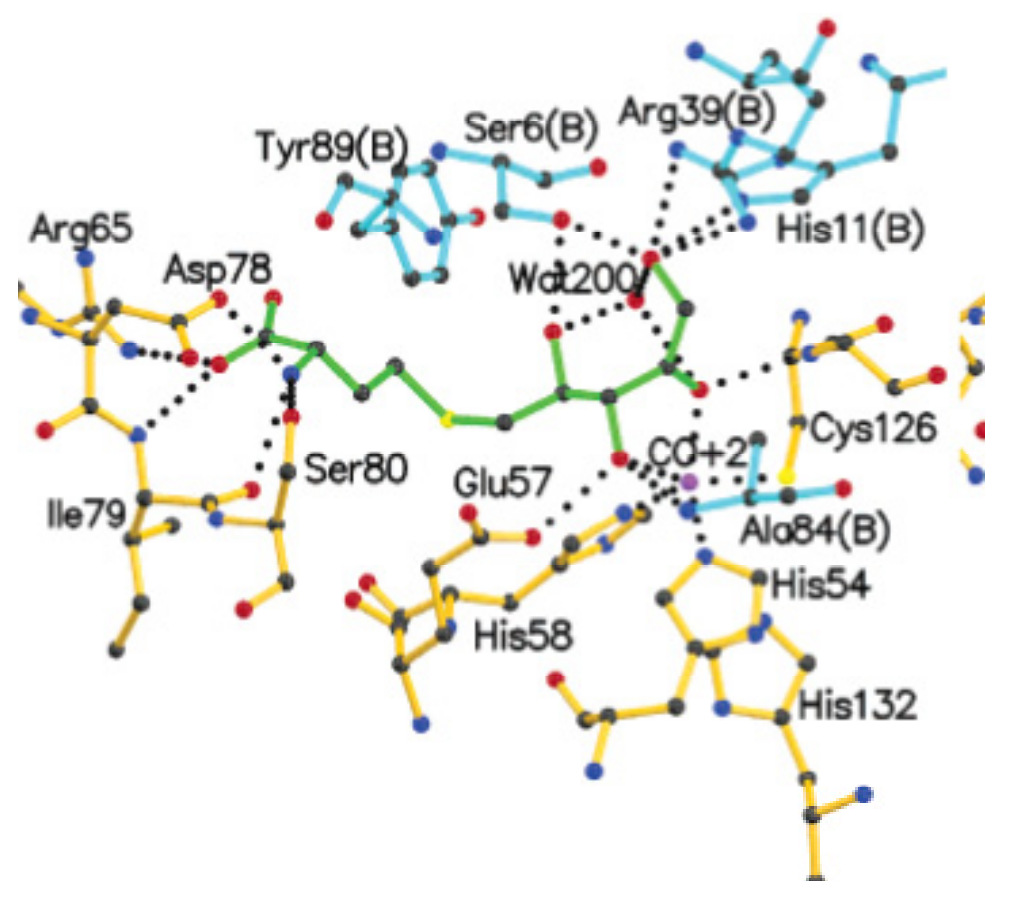

\section{Figure 17. LuxS dimer active site. ${ }^{101}$}

Studies have been conducted to explain the constituent of the interface of LuxS. They aim to show the mechanism of ligand binding and chain connectivity in protein 
dihydrofolate reductase (DHFR). The dimeric state of LuxS enzyme of four organisms which were available to study demonstrated a distinctive fold to the alpha-beta family of proteins. ${ }^{102}$ The LuxS interface includes three vertices of an isosceles triangle. Two of the active clusters have the active site residue while the third one, apex cluster, located at the apex of the dimer with the display loop residues in a mini-triad form arrangement. The active site clusters are made up of three histidines and one glutamine from one subunit and a phenylalanine residue from the other subunit. Thus the active site of subunit $\mathrm{A}$ is supported from phenylalanine of subunit B and vice versa. ${ }^{102}$ This triad is repetitive between the two subunits of the dimeric protein. The mutation of any of the components of the triad has been showed to inactivate LuxS enzyme. ${ }^{102}$

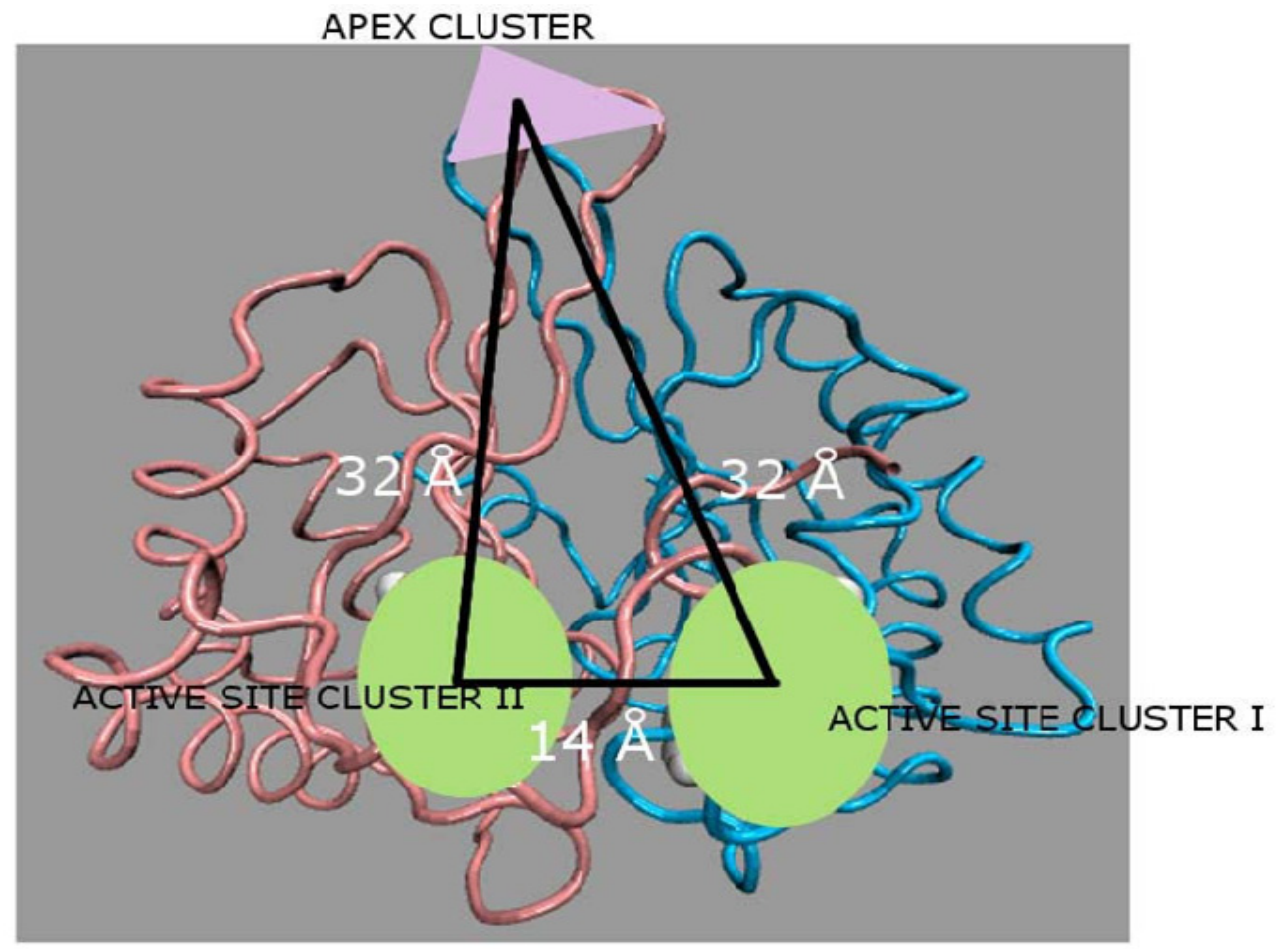

Figure 18. Schematic representation of isoceles orientation of the LuxS. ${ }^{102}$ 
Recently SRH analogues modified at the homocysteine unit (4a) were proposed as potential dimer inhibitors of LuxS (Figure 19). ${ }^{103,104}$ It was hypothesized that inhibitors with the inserted long alkyl/aryl chain at either the $\beta$-carbon or the $\gamma$-carbon of Hcy unit should interfere with two monomers of the protein, which might alter the proximity between the monomers, which in turn should lead to a change in enzyme activity. The steric hindrance at the dimerization site caused by $4 \mathbf{4}$ would result in dimer disruption and subsequently a change in the proximity of the LuxS monomers. It was also proposed that fluorescence proximity assay might be used for the detection of the dimerization inhibition of LuxS by measuring the change in fluorescence upon monomer separation ${ }^{105-}$ ${ }^{107}$ resulting from the supposed interaction of inhibitors $\mathbf{4 a}$ with LuxS protein.

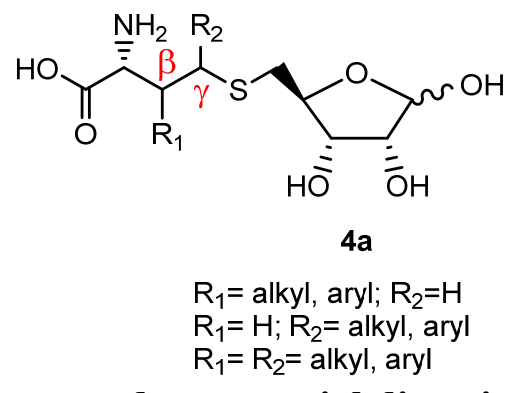

Figure 19. SRH analogues proposed as potential dimerization inhbitors. ${ }^{103,104}$

\subsection{Inhibition of LuxS enzyme by substrate analogues}

General approaches towards the modulations of QS, and AI-2 inhibition strategies in particular, are presented in Table 3. As can be concluded based on the biosynthetic pathway for the production of DPD and consequently AI-2 presented in Scheme 3, the major target responsible for QS inhibition is the LuxS enzyme which controls the production of AI-2. 


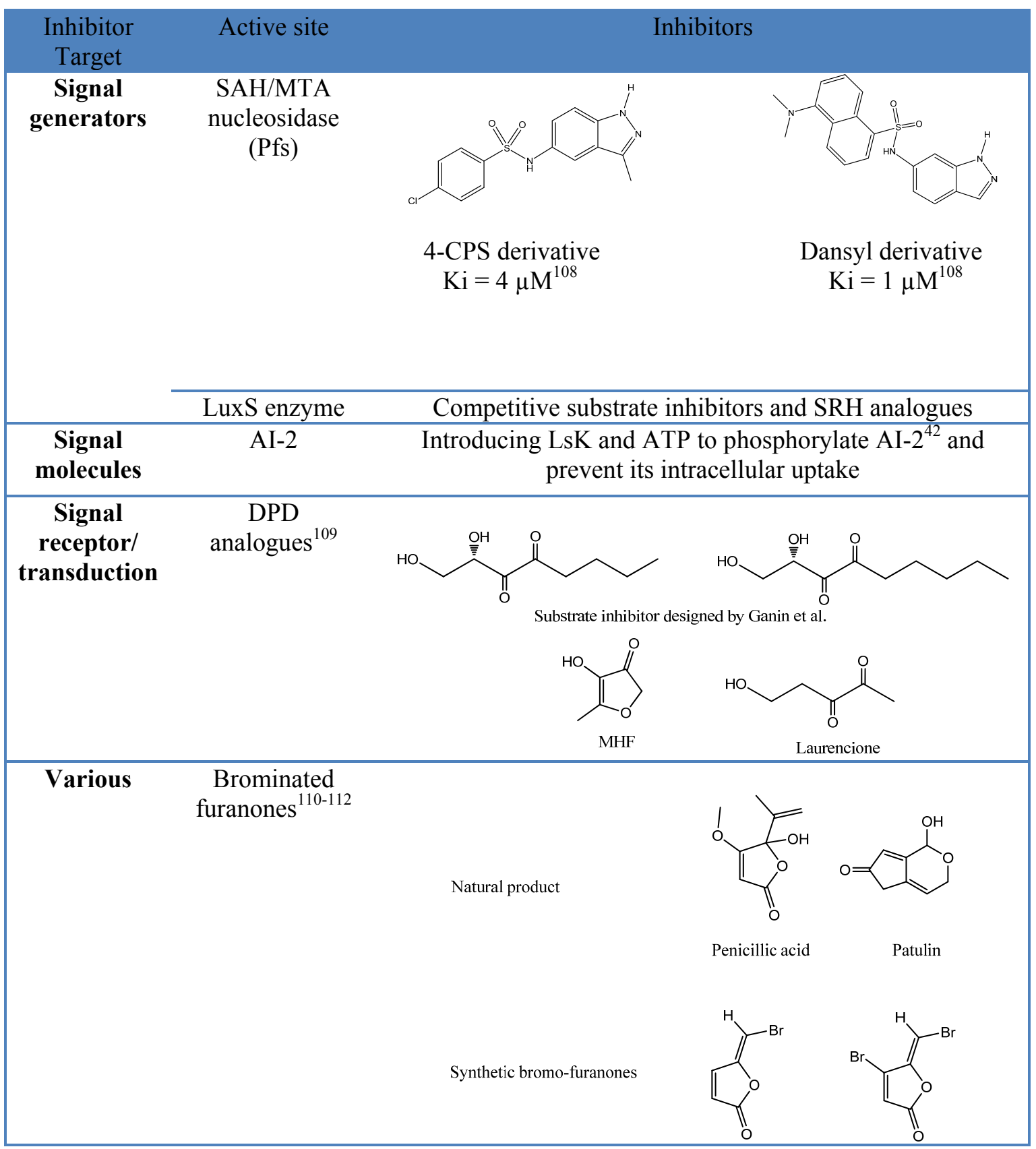

Table 3. Overview of QS inhibition strategies ${ }^{18,42,60,84,109,113-119}$

\subsection{1 $S$-ribosylhomocysteine substrate analogues}

Absent in humans, the LuxS enzyme is considered a smart target for novel antibacterials. Zhou and coworkers ${ }^{19}$ were the first to develop synthetic analogues of SRH which act by competing with the natural substrate SRH 4 (Figure 20). The first 
competitive substrate analogue was $S$-anhydroribosyl-L-homocysteine $13 \mathbf{a}^{19}$ in which the hemiacetal group has been replaced by an ether functional group. Compound 13a should prevent the first step in the catalysis of LuxS enzyme known as the aldo-ketose isomerization. ${ }^{83}$ The presence of the 2,3-diol functional group was expected to ligate to the active site metal ion which allows it to bind to LuxS in a similar fashion as SRH. The second substrate analogue $S$-homoribosyl-L-cysteine $\mathbf{1 3} \mathbf{b}^{19}$ had a replacement of the carbon-sulfur bond (C5-Sulfur) in SRH 3 by a carbon-carbon bond (C5 and C6). Substituting the sulfur atom by a carbon at position 6 should allow 13b to bind properly to LuxS enzyme and undergo aldo-ketose isomerization to form a ketone at $\mathrm{C} 3$ of $\mathbf{1 3 \mathbf { b }}$. Further elimination reaction would however be prohibited since the cleavage of the carbon-sulfur bond cannot occur, preventing elimination of Hcy.

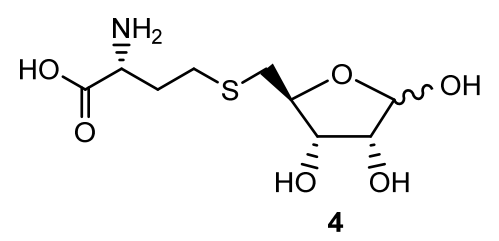

S-ribosyl-L-homocysteine (SRH)
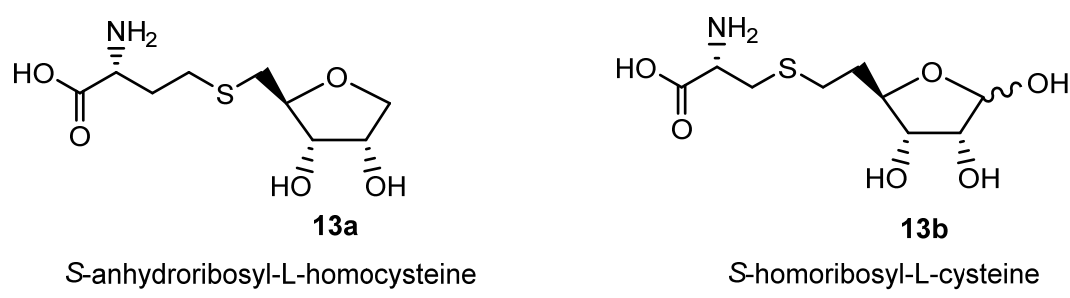

Figure 20. Substrate inhibitors of LuxS enzyme designed by Zhou and coworkers. ${ }^{19}$

Pei and coworkers ${ }^{60}$ designed and synthesized substrates for LuxS enzyme with the an open ribonic acid moiety (Figure 21). Thus, the replacement of the enediolate moiety with a planar hydroxamate group in compound $\mathbf{1 4} 4^{120,121}$ was envisioned to produce 
a stable isostere with high affinity to LuxS. The metal ion in LuxS which was proposed to give the stability of the enediolate intermediate e.g. (4, Scheme 2$)$ was expected to bind to the planar hydroxamate group in $\mathbf{1 4}$. As a stereoisomer of $\mathbf{1 4}$ at the $\beta$-carbon of the hydroxamate, compound $\mathbf{1 5}^{122}$ was expected to have similar LuxS inhibition. Compound 16 (without a Hcy moiety) was also tested to check the importance of the Hcy moiety in the proper binding of the inhibitor to the active site of LuxS. Pei etal. also proposed compound 17 in which the amino acid portion and a metal chelating group ( $N$ formylhydroxylamine) are linked. These compounds were tested against co-(II)substituted B.subtilis LuxS, compounds $\mathbf{1 4}$ and $\mathbf{1 5}$ acted as potent competitive inhibitors with respective $K_{\mathrm{i}}=0.72$ and $0.37 \mu \mathrm{M}$. Compound $\mathbf{1 6}$ had a lower affinity of $K_{\mathrm{i}}>150$ $\mu \mathrm{M}$ which reinforced the importance of the amino acid moiety in the affinity to LuxS. Compound 17 exhibited slight inhibition with $K_{\mathrm{i}}=68 \mu \mathrm{M}$ whereas the SRH analogues 18 and $\mathbf{1 9}$ having Hcy amino acid unit modified did not show inhibitory activity.
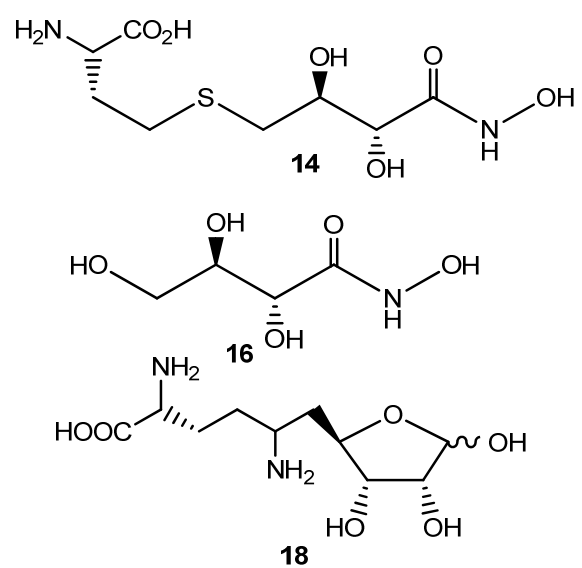
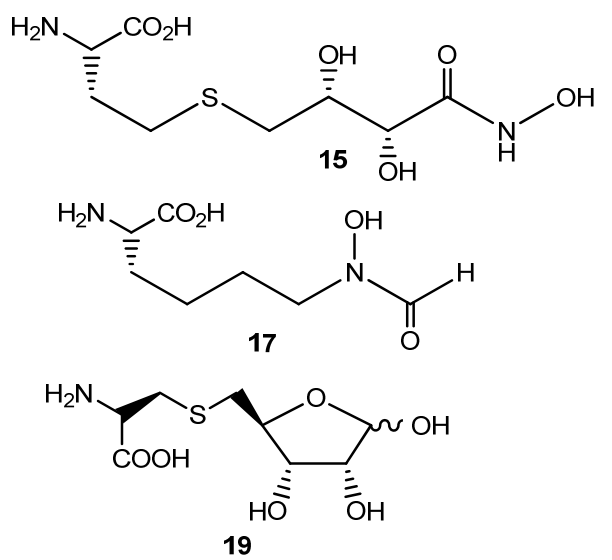

Figure 21. Substrate inhibitors of LuxS enzyme designed by Pei and coworkers ${ }^{60}$ 
Wnuk and coworkers investigated two groups of potential LuxS inhibitors. ${ }^{123,124}$ One group had a vinyl or halovinyl moiety incorporated at C5 of SRH as depicted in compounds 20-23 (Figure 22). In compounds 20-22, the incorporation of the fluoro-vinyl unit was envisioned to target the final step in the LuxS mechanism preventing the $\beta$ elimination to occur. These compounds tested also a possible hydrolytic activity of LuxS enzyme since it was shown that a related $S$-adenosylhomocysteine hydrolase which also catalyzes C5-sulfur bond in the $S$-adenosylhomocysteine, was able to add water across the isolated C5'-C6' bond. ${ }^{123,124}$ As for $\mathbf{2 3},{ }^{123}$ the lack of the hydroxyl group at $\mathrm{C} 3$ of the sugar should prevent the second enolization step of the LuxS catalyzed reaction. No significant inhibition has been reported for the above compounds except 23 (Table 4). The second group of SRH analogues had carbon-3 modification in the ribose ring. These compounds should prevent the second enolisation step in the LuxS catalysis because of (i) the lack of the hydroxyl group as in 3-deoxy-analogue 24, (ii) the lack of the enolizable proton in 3-methoxy analogues 25 and 26, (iii) the inversion of the stereochemistry at $\mathrm{C} 3$ as in xylo-analogue $\mathbf{2 7}$, or (iv) the replacement of the 3-hydroxyl group by a halogen atom as in $\mathbf{2 8}$ and $\mathbf{2 9}$ (Figure 22). Compounds $\mathbf{2 8}$ and $\mathbf{2 9}$ showed time-dependent inhibition of LuxS, while compounds 20-22 did not show any inhibitory activity. The loss of fluoride ion via the postulated $\mathrm{E} 1 \mathrm{cB}$ elimination reaction in $\mathbf{2 8}$ instead of the nucleophilic substitution in the bromo atom in $\mathbf{2 9}$ led to the faster conversion of the initial enzyme-inhibitor complex E-I in $\mathbf{2 8}$ into a tighter enzymeinhibitor complex E· $I^{*}$ than in $\mathbf{2 9}$. 


\begin{tabular}{|c|c|c|}
\hline \multirow{7}{*}{$\begin{array}{l}\text { Competitive } \\
\text { inhibitors }\end{array}$} & Compound & $K_{\mathrm{i}}$ \\
\hline & 23 & $96 \mu \mathrm{M}$ \\
\hline & 24 & $55 \mu \mathrm{M}$ \\
\hline & 25 & $66 \mu \mathrm{M}$ \\
\hline & 26 & $42 \mu \mathrm{M}$ \\
\hline & 28 & $10.6 \mu \mathrm{M}$ \\
\hline & 29 & $7.9 \mu \mathrm{M}$ \\
\hline
\end{tabular}

Table 4. Ki values of different substrate inhibitors of LuxS. ${ }^{124,125}$<smiles>COC(=O)CCC/C(F)=C/[C@H]1O[C@H](O)[C@H](O)[C@H]1O</smiles><smiles>[Y]C1[C@H](/C=C/F)O[C@@H](O)[C@@H]1O</smiles>

$21 \mathrm{X}=\mathrm{OH}, \mathrm{Y}=\mathrm{H}$ $22 \mathrm{X}=\mathrm{H}, \mathrm{Y}=\mathrm{OH}$ $23 \mathrm{X}=\mathrm{H}, \mathrm{Y}=\mathrm{H}$<smiles>[Y]C1[C@H](CSCC[C@H](N)C(=O)O)O[C@@H](O)[C@@H](O)[C@@H]1[Y]</smiles>

$24 \mathrm{X}=\mathrm{Y}=\mathrm{H}$

$25 \mathrm{X}=\mathrm{OMe}, \mathrm{Y}=\mathrm{H}$ $26 \mathrm{X}=\mathrm{H}, \mathrm{Y}=\mathrm{OMe}$<smiles>N[C@@H](CCSC[C@H]1O[C@@H](O)[C@@H](O)[C@H]1O)C(=O)O</smiles>

27<smiles>[X]C1C(CSCC[C@H](N)C(=O)O)O[C@@H](O)[C@@H]1O</smiles>

$28 \mathrm{X}=\mathrm{F}$ $29 \mathrm{X}=\mathrm{Br}$

Figure 22. Substrates of LuxS enzyme synthesized by Wnuk and coworkers. ${ }^{123,124}$

Two 3-halogeno-substituted SRH analogues (3-Br-SRH; 29 and 3-F-SRH; 28) acted as potential suicide inhibitors for LuxS. ${ }^{125}$ Since both molecules have a halogen (either bromide or fluoride) at carbon C3 instead of a hydroxyl group, they were expected to 
bind to the active site of LuxS and to alert the enolization reaction that occurs at $\mathrm{C} 3$ to prevent the ketone formation at C3 (see Scheme 3). Detailed mechanistic studies performed in Professor Pei's laboratory demonstrated that 3-[Br]-SRH 29 and 3-[F]-SRH 28 inhibit LuxS by different mechanisms. ${ }^{125}$ In the case of $\mathbf{2 9}$, the negatively charged Cys-84 nucleophilically attacks $\mathrm{C} 3$ in $\mathbf{2 9 b}$ (reactive $\alpha$-bromoketone) leading to the loss of bromide ion and the formation of a new covalent adduct between $\mathrm{C} 3$ of the ribose ring and the sulfur atom of Cys-84 as shown in 29c (Scheme 6).

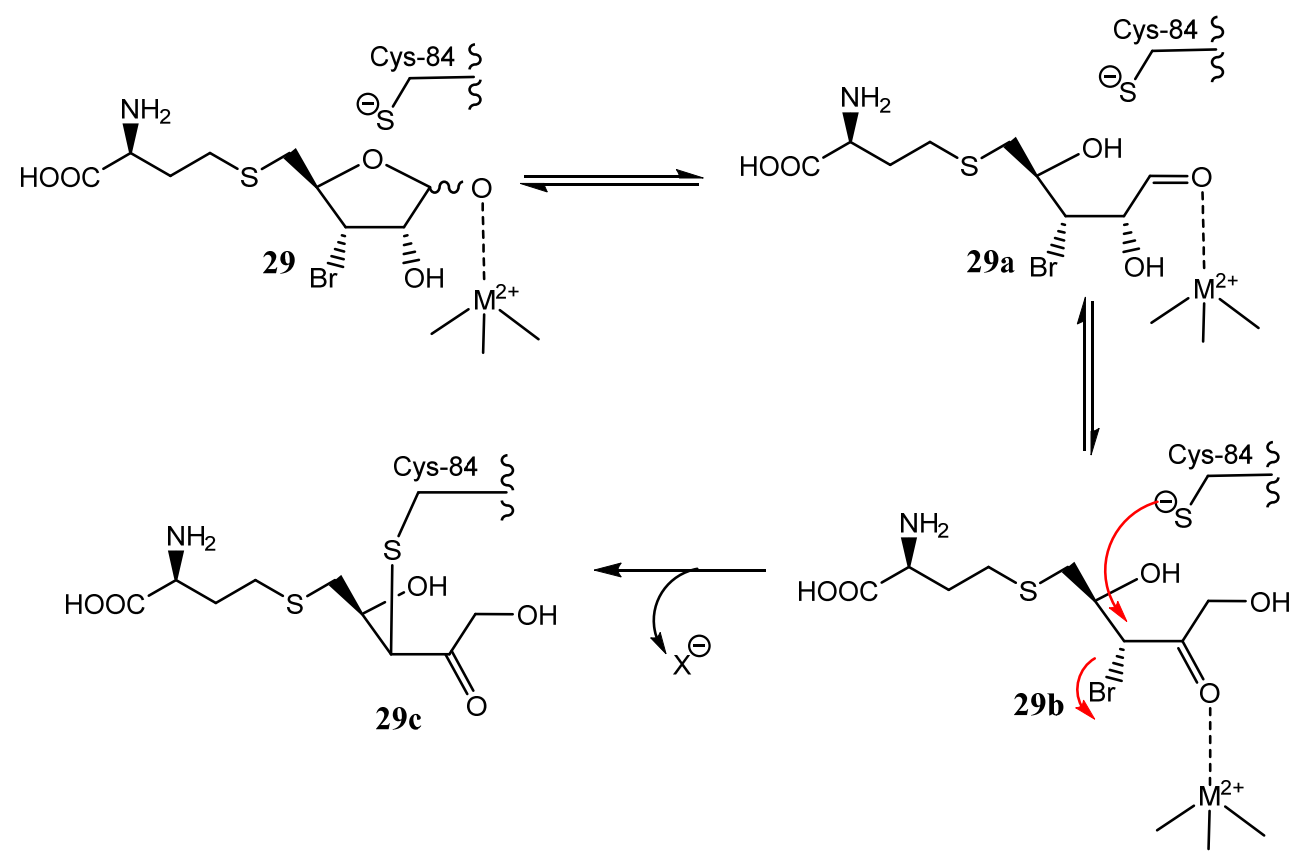

Scheme 6. Proposed mechanism for the inhibition of LuxS by 3-Br-SRH. ${ }^{125}$

In the case of 28, the negatively charged Cys- 84 abstracts the acidic $\alpha$ proton at $\mathrm{C} 2$ of the hydroxy-aldehyde 28a leading to the loss of fluoride ion via the postulated E1cB elimination reaction. The formed enol $\mathbf{2 8 b}$ could exist in equilibrium with the diketone 28c or undergo hydration to form $\mathbf{2 8 d}$ (Scheme 7). 

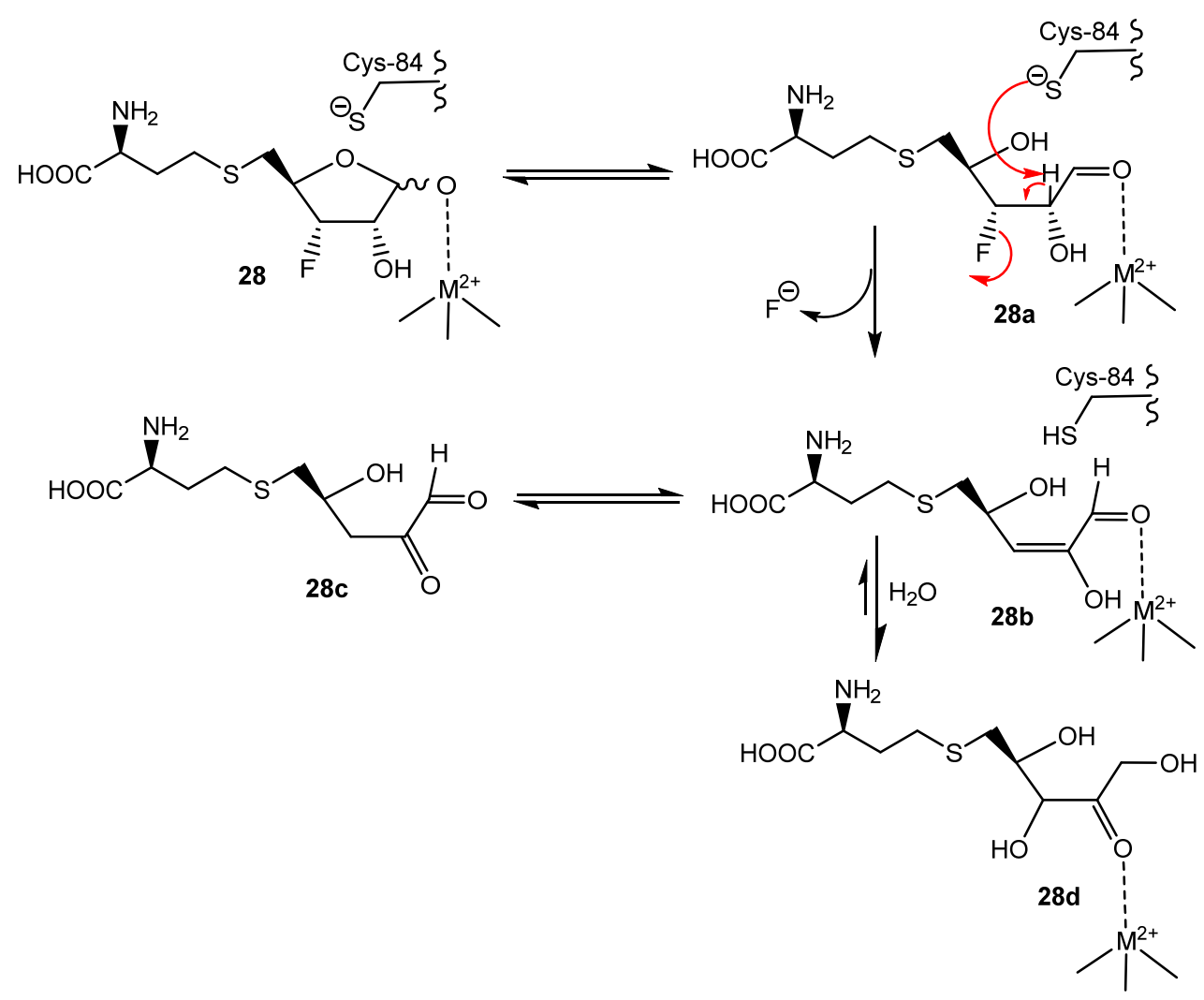

\section{Scheme 7. A plausible mechanism for the inhibition of LuxS by 3-F-SRH. ${ }^{125}$}

Wnuk and coworkers also designed the 4-aza-SRH analogues, in which nitrogen replaces the oxygen atom of the furanose ring (Figure 23). ${ }^{126}$ The hemiaminal derivatives (e.g. 32) were expected to have different stabilities compared to the $O, O$-hemiacetals present in SRH 3 which should result in different rates of metabolism. The binding strength of the aza analogues were expected to be different than the hemiacetals mainly because of the higher basicity of the nitrogen atom in the aza compounds as compared to the oxygen atom in the natural substrate SRH. Thus the binding strengths and rate of production of the open chain aldehyde was expected to be different. In addition, the aminosugars are more prone of protonation at physiological $\mathrm{pH}$ which should also alter the enzymatic activity. 

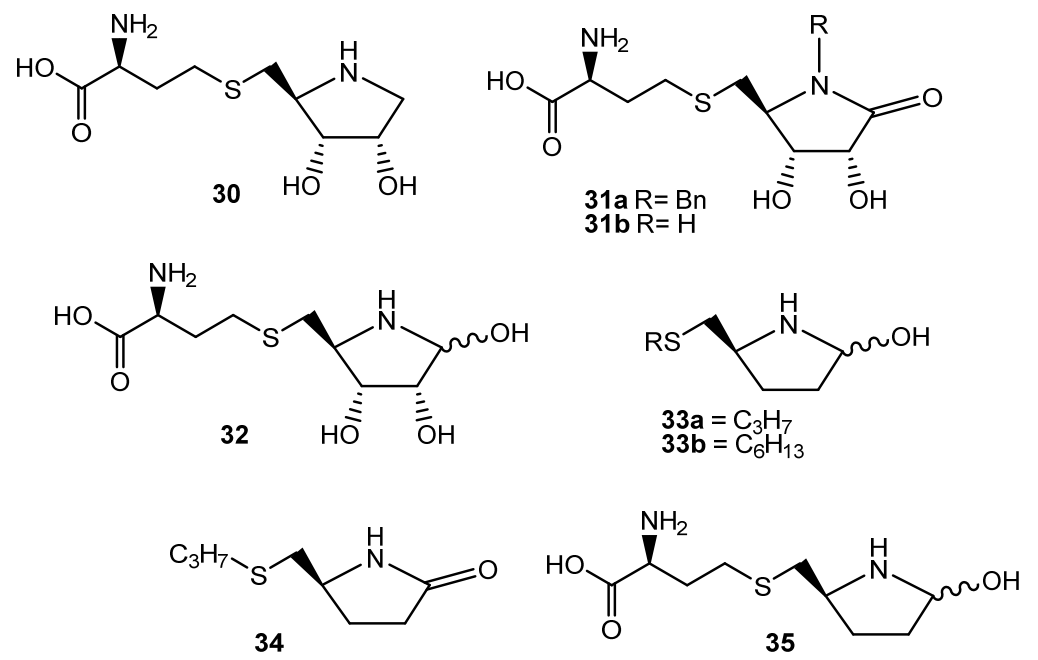

Figure 23. 4-[aza]-SRH analogues. ${ }^{126,127}$

The aza-analogue 30 lacking a hydroxyl group at C1 showed a concentration dependent inhibition of LuxS that was consistent with competitive inhibition $\left(\mathrm{K}_{\mathrm{i}}=48\right.$ $\mu \mathrm{M})$. The lactam 31b had a $\mathrm{K}_{\mathrm{i}}$ value of $37 \mu \mathrm{M}$ while the $N$-benzyl protected lactam 31a was found to be inactive mostly due to the steric reasons. The aza analogues lacking hydroxyl groups at $\mathrm{C} 2$ and $\mathrm{C} 3$ as in $\mathbf{3 3 - 3 5}$ were inactive mainly due to the absence of the hydroxyl groups which are important to coordinate with the catalytic metal ion in the LuxS protein. Unlike other aza-analogues, the hemiaminal 32 was found to be a timedependant inhibitor of LuxS with $\mathrm{IC}_{50}$ value of $60 \mu \mathrm{M}$ and $\mathrm{K}_{i}$ value of $3.5 \mu \mathrm{M}$. The timedependent inhibition of LuxS by 32 might indicate that the hemiaminal exists in the equilibrium with the free aldehyde form 32a as depicted in Figure 23. The aldehyde 32a was proposed to undergo aldose-ketose isomerization reaction to generate 2-keto intermediate 32b and consequently 3-keto intermediate 32c. However, no spectroscopic proofs for the presence of the formation of the 2 or 3 -keto intermediate were found. ${ }^{126}$ 
The mechanism of inhibition of LuxS by aza-analogues appears to be similar to the initial step of the inhibition of LuxS by the halogenated SRH analogues such as [3Br-SRH] and [3-F-SRH] which also showed to undergo LuxS-catalysed ring opening. ${ }^{125}$

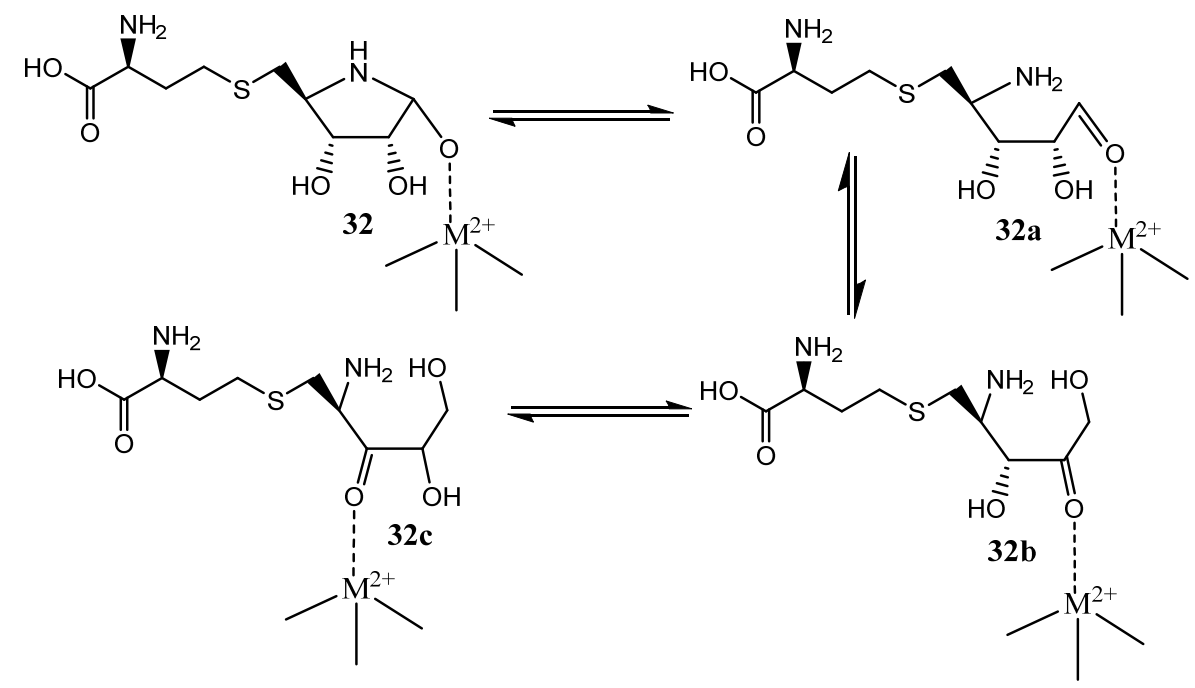

\section{Scheme 8. Plausible mechanism for the time-dependent inhibition of LuxS by 4-aza- SRH hemiaminal $32 .{ }^{126}$}

The aza analogues $\mathbf{3 3}$ (aza-hemiacetal) and the corresponding lactam $\mathbf{3 4}$ in which the Hcy unit was replaced by an alkyl-thio group bearing a long alkyl chain, acted as strong inhibitors against AHL-dependent las (activity $43 \%$ at $\left[\begin{array}{lll}1.16 & \mathrm{mM}\end{array}\right]$ inhibitor concentration) and weaker ones against $r h l$ (activity 104\% at [1.16 mM] inhibitor concentration) QS pathways in P. aeruginosa. Antagonism of las activity has been increased with the length of the alkyl-thio chain. The hexylthio-analogue 33b appeared to be the strongest inhibitor among the tested compounds (las activity $0 \%$; rhl activity $0 \%$ ) against both las and $r h l$ systems. ${ }^{127}$

The other strategies for modulating QS and effecting production of AI-2, which were presented in Table 3, include the novel synthetic analogues of $\mathrm{DPD}^{128,129}$ or the 
brominated furanoses ${ }^{110-112}$ and other small molecules that have been recently reviewed. $^{129}$

An interesting approach for the inhibition of bacterial QS was recently developed by Meijler's group which is based on the covalent modification of a QS receptor as a new tool to study molecular mechanism of bacterial group behavior and to target bacterial virulence. Meijler's group developed isothiocyanate and $\alpha$-halomethyl carbonyl probes which are modified AHL analogues (Figure 24). ${ }^{91}$ These very reactive isothiocyanate and haloacetamide analogues were envisioned to react with proximal nucleophiles via "azido free" click-chemistry leading to covalent inhibition and molecule labeling. These analogues were shown to strongly inhibit $P$. aeruginosa QS-related gene expression (las) resulting in the inhibition of the transcriptional activator LasR.

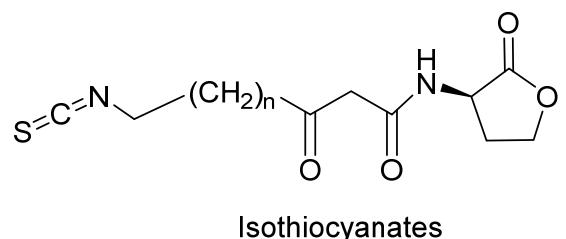

Isothiocyanates

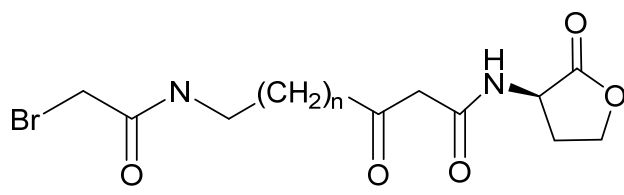

Bromoacetamides

Figure 24. AHL analogues modified with isothiocyanates and bromoacetamides. ${ }^{91}$ 


\section{RESEARCH OBJECTIVE}

The objective of this dissertation is the design, synthesis and biological evaluation of novel LuxS inhibitors which should interfere with quorum sensing processes. My initial targets were $S$-ribosylhomocysteine [SRH] analogues in which the hydroxyl group at C2 in the ribofuranose ring of the SRH would be substituted by halogens such as bromide or fluoride. The two main targets of the C2-substituted sugar analogs are 2-deoxy-2-fluoroD-ribosylhomocysteine 36a and its corresponding arabino-epimer $\mathbf{3 6 b}$ as well as 2deoxy-2-bromo-D-ribosylhomocysteine 37a and its arabino-epimer 37b (Figure 25). The targeted 2-halo-SRH analogues are envisioned to interact with the LuxS protein differently than the natural substrate $S$-ribosylhomocysteine does, upon binding to the LuxS enzyme. Thus, 2-halo-SRH analogues, lacking the 2-hydroxyl group, should prevent the formation of the 2-keto intermediates (e.g., complex 6, Scheme 3) during the interaction with LuxS.

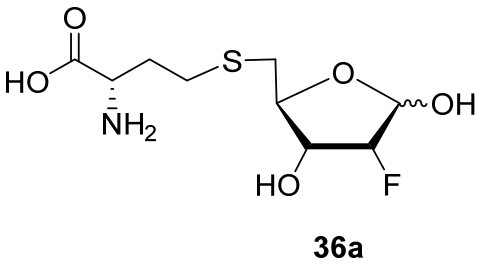

2-[F]-SRH

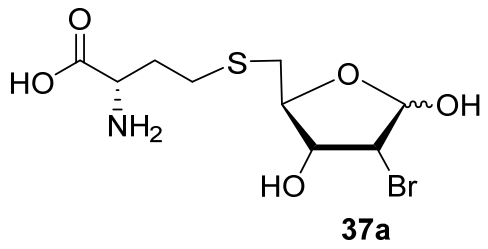

2-[Br]-SRH
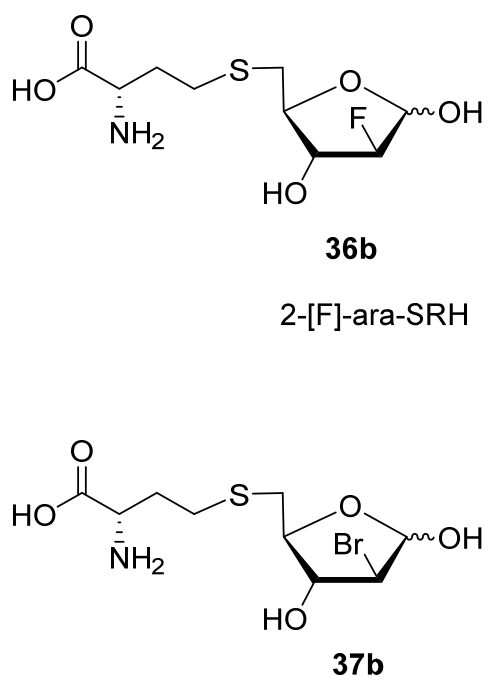

2-[Br]-ara-SRH

Figure 25. Targeted 2-deoxy-2-halo-S-ribosylhomocysteine analogues. 
It is postulated that the 2-[F]-SRH analogue 36a after ring opening and abstraction of the acidic $\mathrm{H} 2$ proton by proximal Cys 84 (from the $\beta$ face) should lead to the formation of the fluoro-enol intermediate 36d rather than the 2-keto intermediate which is formed during metabolism of the natural SRH (see Scheme 3).

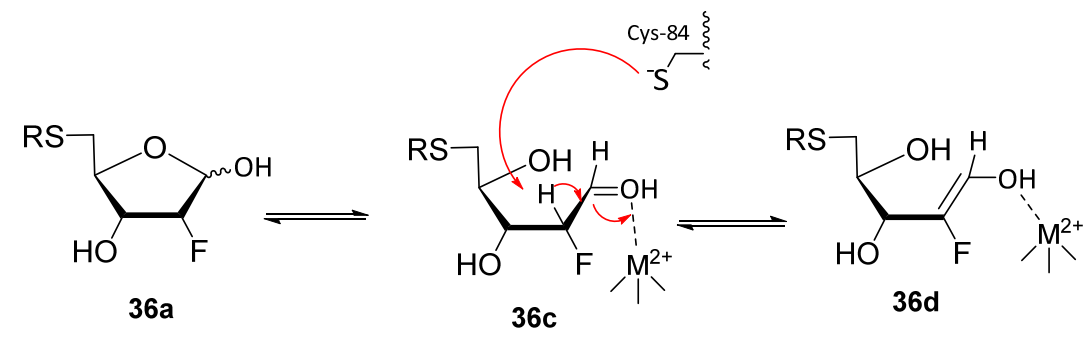

\section{Scheme 9. A possible mechanism of inhibition of LuxS by 2-[F]-SRH.}

The interaction of LuxS with 2-[Br]-SRH analogue 37a might occur by the formation of the analogous bromo-enol intermediates or by the nucleophilic displacement of bromide. Based on the previous studies with 3-halo-SRH analogues ${ }^{125}$ (see Scheme 6), it is reasonable to expect that after ring opening the reactive $\alpha$-bromo-ketone intermediate 37c might be a substrate for nucleophilic substitution by the active site Cys- 84 leading to a covalent inhibition as depicted in Scheme 10.

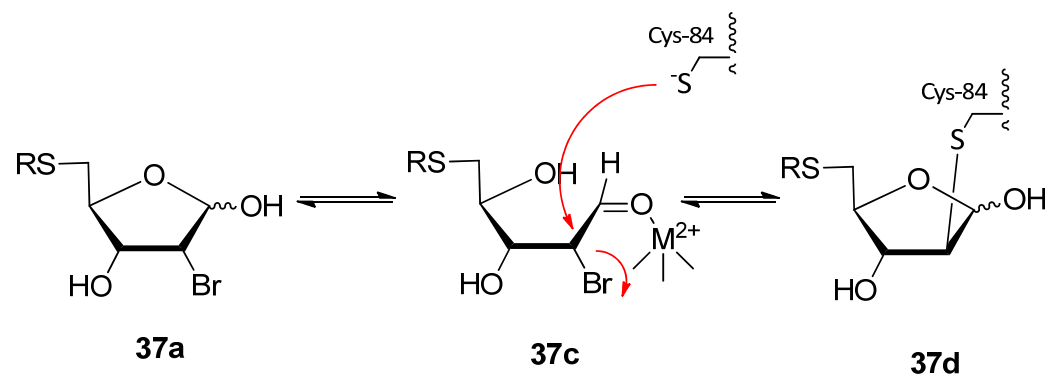

\section{Scheme 10. Plausible inhibition of LuxS by 2-[Br]-SRH.}

The displacement of the bromide by cysteinate thiol could occur at either closed or opened form of the ribose ring. However, because of the different stereochemical 


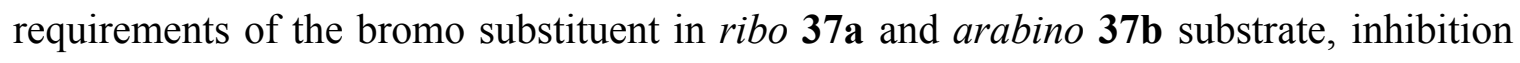
might also shed some light on the leniency of the active site for the stereochemical regimen of the substituent at the $\mathrm{C} 2$ of the ribose ring. For example, the bromo substituent at the $\beta$ face in the arabino substrate $37 \mathbf{b}$ might prevent $\mathrm{S}_{\mathrm{N}} 2$ displacement which requires a nucleophilic attack by Cys 84 from the opposite site of the leaving group (bromide). The fact that all four 2-halo-2-deoxy-SRH analogues lack the 2-hydroxyl group, the first tautomerization step and the generation of the 2-keto-SRH intermediate, which is critical for the enzymatic activity of LuxS might be prevented.

My second targets were SRH analogues in which the hydrogen at $\mathrm{C} 4$ of the ribose ring is substituted by an alkyl group of varying length (e.g. alkyl, vinyl and aryl; Figure 26). These 4-C-alkyl-SRH analogues are targeted for two reasons. First, I anticipated that 4-C-alkyl-[SRH] analogues because of the lack of hydrogen at $\mathrm{C} 4$ would prevent the elimination of Hcy (as depicted in Scheme 3, conversion $\mathbf{7} \rightarrow \mathbf{8}$ ) effecting the overall production of DPD (Scheme 11). Secondly, since LuxS is a biologically active homodimer with a triad interface, ${ }^{102}$ the addition of an alkyl group could lead to the destabilization of the LuxS dimer.

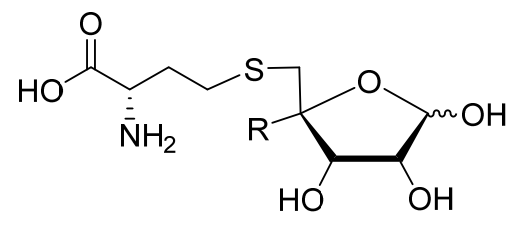

$\mathrm{R}=$ methyl, hexyl, octyl, vinyl, 4-methoxyphenyl

Figure 26. 4- $C$-alkyl-substituted SRH analogues (4-[R]-SRH). 


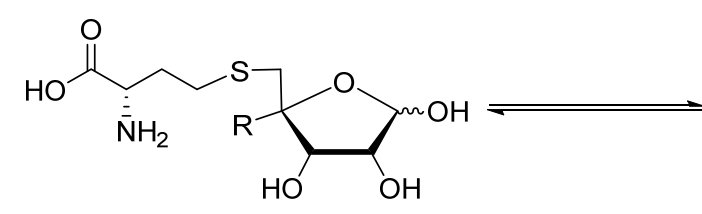

$\mathrm{R}=$ methyl, hexyl, octyl, vinyl, 4-methoxyphenyl

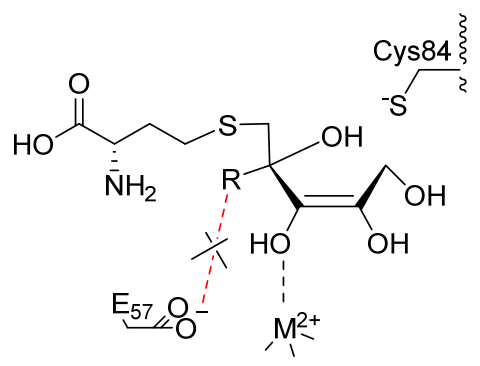

\section{Scheme 11. A plausible mechanism for the inhibition of LuxS by 4-[R]-SRH analogues.}

The next goal of my dissertation was the synthesis of 4-[thia]-SRH mimics (e.g. 39) in which the furanose ring oxygen has been replaced by a sulfur atom (Figure 27). The resulting thiohemiacetal $(O, S$-acetals) should have different stabilities relative to the $O, O$-acetals present in $\mathrm{SRH}$ and as a result different rates of metabolic alteration. The expected increased stability of the glycosyl bond should therefore result in decreased rates of metabolic degradation and effect production of the open chain aldehyde form necessary for the first LuxS-catalyzed isomerization to occur. Moreover, the [4-thia]SRH analogues can be converted to a thio-analogue of DPD 39a which could interfere with QS because of the different ability for the ring closure (e.g, 39b) and consequently different capability of the resulting thiol group to form covalent bonds with borate to generate possible thio-analogues of AI-2 signaling molecules. 

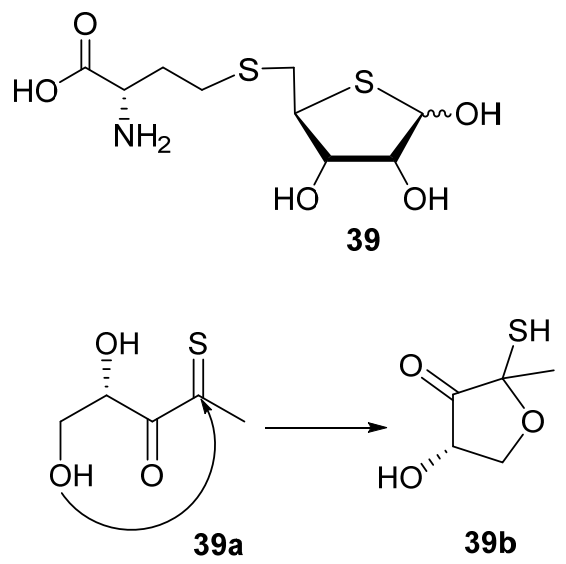

Figure 27. The SRH analogues with furanose ring oxygen substituted by sulfur ([4thia]-SRH) and the expected thio-analogues of DPD

The last goal in my dissertation is to evaluate the activity of the target compounds against LuxS enzyme and to test them as possible quorum sensing modulators of $P$. aeuroginosa and $V$. harveyi. The significance of this work is to design and synthesize new molecules with the capability to interfere with the quorum sensing pathway considered as the main communication method among most Gram positive and Gram negative bacteria. In vitro and in vivo studies will be necessary to evaluate the molecules as an emerging class of antibiotics. 


\section{RESULTS AND DISCUSSION}

\subsection{Design and synthesis of 2-halo substituted $S$-ribosylhomocysteine analogues}

LuxS enzyme might interact with 2-halo-SRH analogues (e.g., 36 or 37) through the novel mode of actions. Thus, ring opening of 2-fluoro-SRH substrate 36a and complexation of the metallo-Lewis acid with the carbonyl group will make $\mathrm{H} 2$ susceptible to the abstraction by the proximal Cys- 84 as presented in complex 36c (Scheme 12). The generated in situ fluoroenol 36d might interact with electrophiles leading to the alkylation at $\mathrm{C} 2$ as depicted in $\mathbf{3 6 e}$.

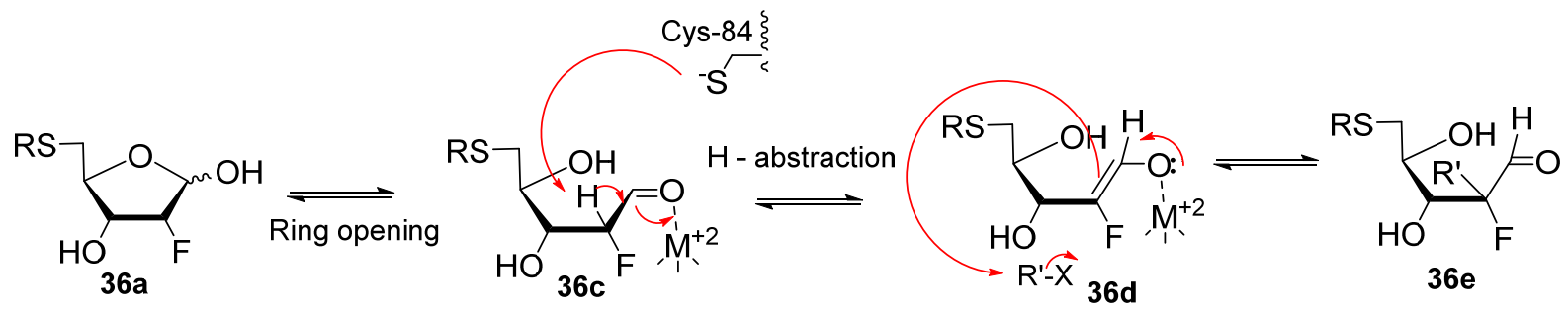

\section{Scheme 12. A plausible inhibition of LuxS by 2-[F]-SRH via $\mathrm{H} 2$ abstraction.}

In a second mode of action, after a ring opening, Cys- 84 might abstract $\mathrm{H} 3$ from the intermediate 36c which will result in elimination of fluorine in E1cB fashion to produce an enone which could further tautomerize to 1,3-dicarbonyl intermediate 36f (Scheme 13). This 3-keto intermediate could subsequenly undergo $\beta$-elimination to release homocysteine and produce 3,4-dioxopentanal (DOP) $\mathbf{3 6 g}$ as a highly oxidized analogue of DPD (precursor of AI-2). Conversely, abstraction of H3 might happen prior to the ring opening leading however to same 1,3-dicarbonyl intermediate. 


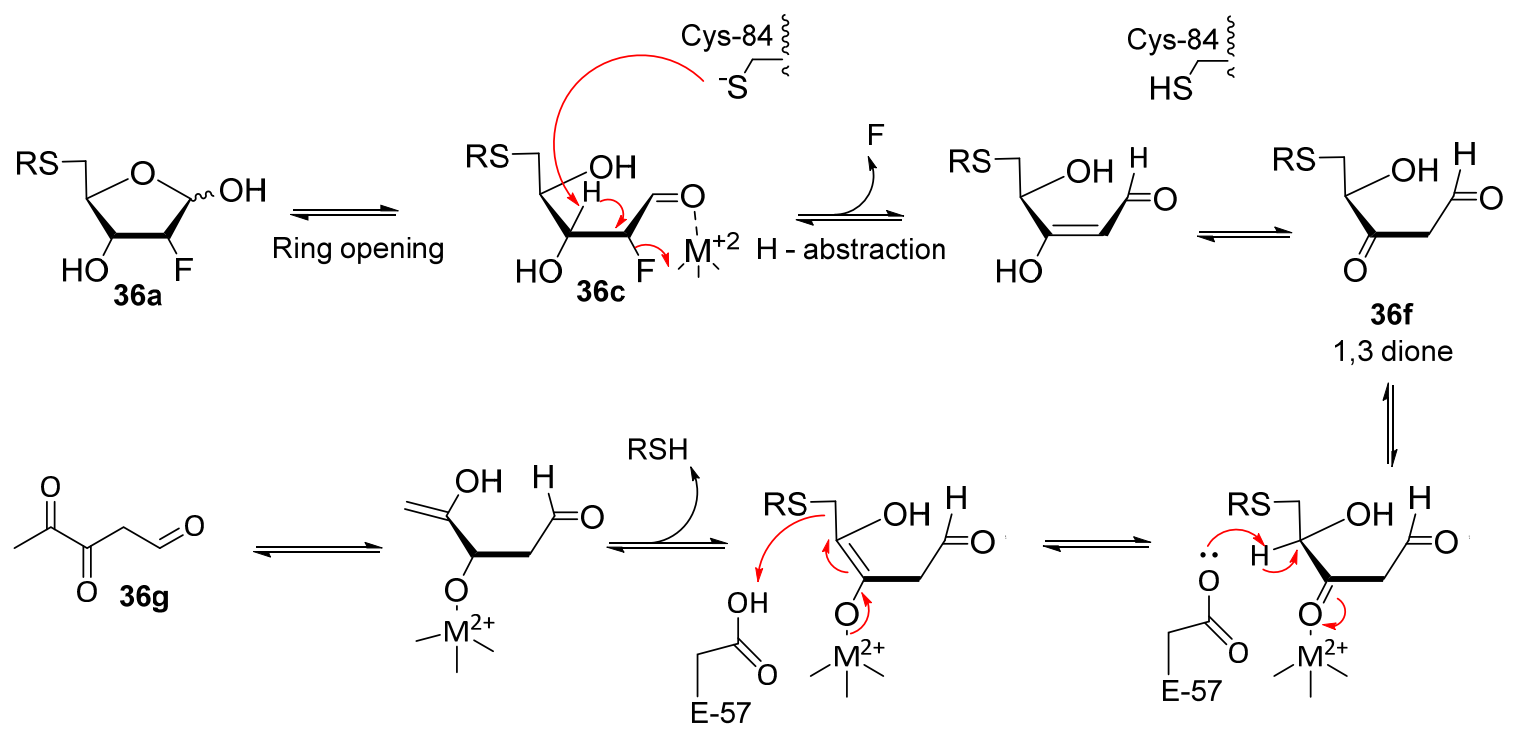

\section{Scheme 13. A plausible inhibition of LuxS by 2-[F]-SRH via $\mathrm{H3}$ abstraction.}

Different stereochemistry at $\mathrm{C} 2$ in $2-[\mathrm{F}]$-arabino-SRH 36b ( $\mathrm{F}$ is in $\beta$-face) might preclude abstraction of $\mathrm{H} 2$ by Cys-84, which is known from X-ray studies on LuxS to be positioned on the $\beta$-face of the substrate, therefore I would expect the attack at $\mathrm{C} 3$ to be a major pathway of interaction of 2-[F]-arabino-SRH with LuxS.

In the case of 2-[Br]-SRH, since the bromine is a much better leaving group than fluorine, I expect that direct replacement of bromine by Cys-84 via $\mathrm{S}_{\mathrm{N}} 2$ mechanism might lead to the covalent inhibition by the attack of Cys-84 at C2. The attack might happen at the hemiacetal (path 1, Scheme 14) or opened ring form of the bromo-substrate (path 2, Scheme 14). The formation of enzyme-inhibitor complexes can be detected using a mass spectroscopy technique. 
Path 1
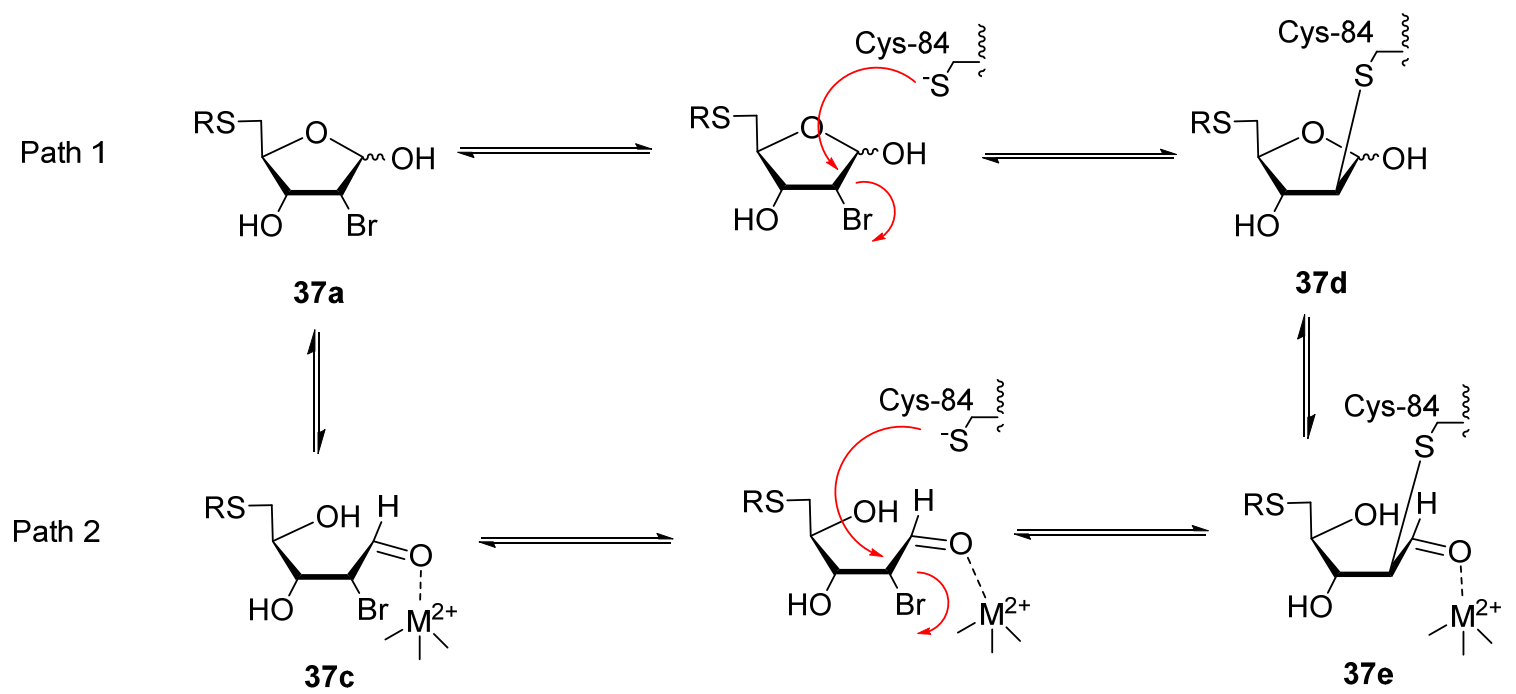

\section{Scheme 14. A plausible inhibition of $\operatorname{LuxS}$ by 2 -[Br]-SRH via $S_{N} 2$ mechanism.}

\subsubsection{Synthesis of 2-bromo-2-deoxy-S-ribosylhomocysteine analogues}

The synthesis of the 2-bromo-2-deoxy-SRH 37a was divided into two steps. In the first step the 2-bromo-2-deoxyribose precursor $\mathbf{4 5}$ was prepared (Scheme 15), while the second step was envisioned as the coupling between $\mathbf{4 5}$ and the homocysteine thiolate $\mathbf{4 9}$. The bromo-sugar precursor $\mathbf{4 5}$ was prepared according to the literature report. ${ }^{130}$ It started with the oxidation of the 2-deoxyribose 40 with $\mathrm{Br}_{2} / \mathrm{H}_{2} \mathrm{O}$ to 2-deoxyribonolactone 41 . The treatment of the resulting $\mathbf{4 1}$ with TBDMSCl produced a disilylated ribonolactone $\mathbf{4 2}$ with $80 \%$ yield. Direct bromination of $\mathbf{4 2}$ with NBS, following the procedure developed by Sauve, ${ }^{130}$ led to the formation of the bromo-lactone $\mathbf{4 3}$ as a mixture of arabino/ribo epimers in 2:1 ratio. The formation of $\mathbf{4 3 a}$ and $\mathbf{4 3} \mathbf{b}$ was consistent with the bromination of the intermediate enolate. However, the obtained mixture of the arabino and riboepimers differed from the reporting in literature (arabino/ribo, 1:1.4) ${ }^{130}$ ratio. The arabino/ribo epimers of $\mathbf{4 3}$ were successfully separated using column chromatography. 
Compound $\mathbf{4 3}$ was considered as a precursor for the synthesis of the mesylated derivative $\mathbf{4 5}$ intended to be coupled with the homocysteine thiolate to afford the desired final product 50. Thus, deprotection of $\mathbf{4 3}$ with TFA/ $\mathrm{H}_{2} \mathrm{O}(9: 1)$ effected selective removal of TBDMS group from the primary 5-hydroxyl group of $\mathbf{4 3}$ to afford $\mathbf{4 4}$ in $90 \%$ yield. Treatment of $\mathbf{4 4}$ with mesyl chloride in pyridine produced the desired 5-O-mesyl derivative $\mathbf{4 5}$ in 60\% yield (Scheme 15).

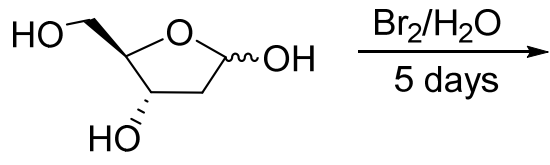

40

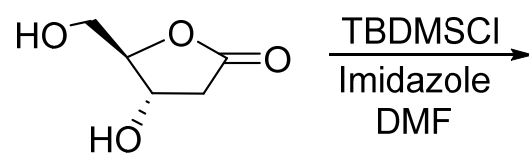

41

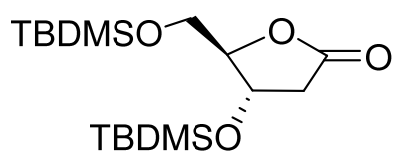

42

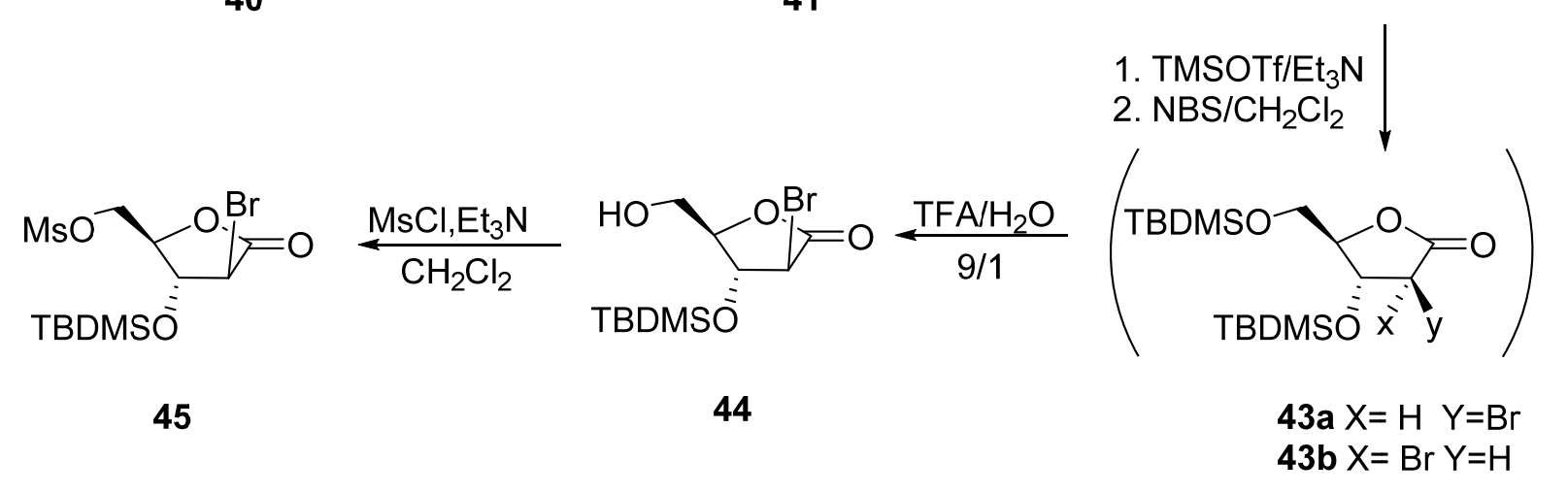

Scheme 15. Synthesis of the 2-bromo-2-deoxy-5-O-mesyl-ribono/arabinono lactone derivatives.

The protected homocysteine precursor 49 was prepared starting from the commercially available L-homocystine $\mathbf{4 6}$ following the literature protocol ${ }^{67}$ (Scheme 15). Thus, treatment of the homocystine $\mathbf{4 6}$ with di-t-butyl dicarbonate gave $N$-Boc protected homocysteine $\mathbf{4 7}$. Next, the carboxylic group in $\mathbf{4 7}$ was protected as tert-butyl ester upon treatment with diisopropylcarbodiimide (DIC) and $t$-butanol. The reduction of the disulfide bond in $\mathbf{4 8}$ with triscarboxyethylphosphine hydrochloride (TCEP) followed by aqueous workup afforded the homocysteine 49 of the appropriate purity for the 
coupling with sugar precursors. It is noteworthy that employing $\mathrm{TCEP}^{124}$ as water soluble reducing agent rather than organic soluble trialkylphosphines ${ }^{67,83}$ simplified the preparation of the protected homocysteine substrate 49 .

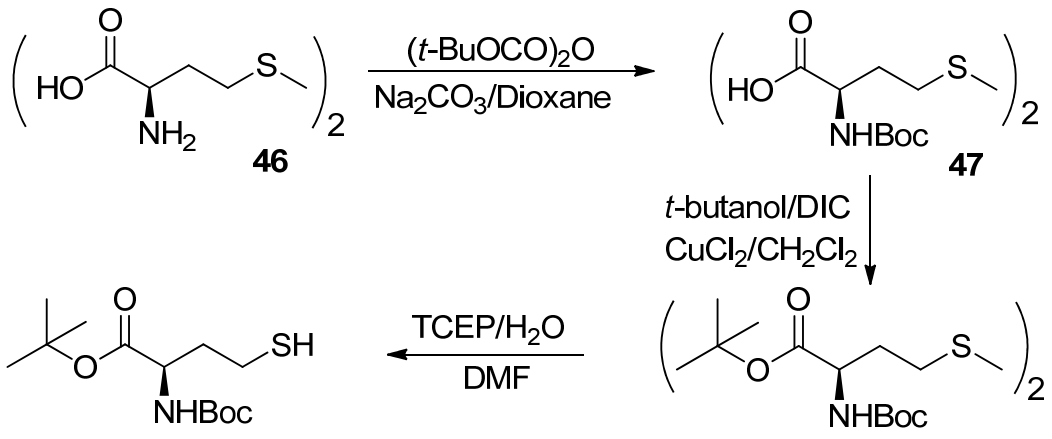

49

48

\section{Scheme 16. Synthesis of homocysteine-thiolate.}

Two methods for the displacement of the mesylate group in the ribonolactone $\mathbf{4 5}$ with thiolate anion generated from homocysteine 49 were attempted. In the first approach, LDA was used as a base and DMF as a solvent. Thus, coupling of 49 and 45 in DMF resulted in the formation of the complex reaction mixture. Careful purification of the crude reaction mixture on the column chromatography resulted in the isolation of few products in low yields which showed no presence of bromine in their mass spectra.

In the second approach $\mathrm{K}_{2} \mathrm{CO}_{3}$ was used as a base and dry acetone as solvent. The complex reaction mixture was purified on column chromatography and desired product 50' was not isolated (Scheme 17). Proton NMR of the crude reaction mixture showed however the characteristic pattern for the protons of homocysteine and sugar moieties. Mass spectra analysis of the major fraction, showed no presence of the typical pattern of bromine isotopes $(\mathrm{M} / \mathrm{M}+2)$. 
The complexity for the displacement reactions maybe attributed to the fact that the bromine at $\mathrm{C} 2$ in the ribonolactone precursor 45 (at $\mathrm{C} \alpha$ to ester carbonyl) also is a good leaving group and might be involved in nucleophilic substitution reaction with homocysteinate salts leading to 50. To prove this hypothesis, I carried out a reaction between $\mathbf{4 5}$ with model alkyl-thiol.

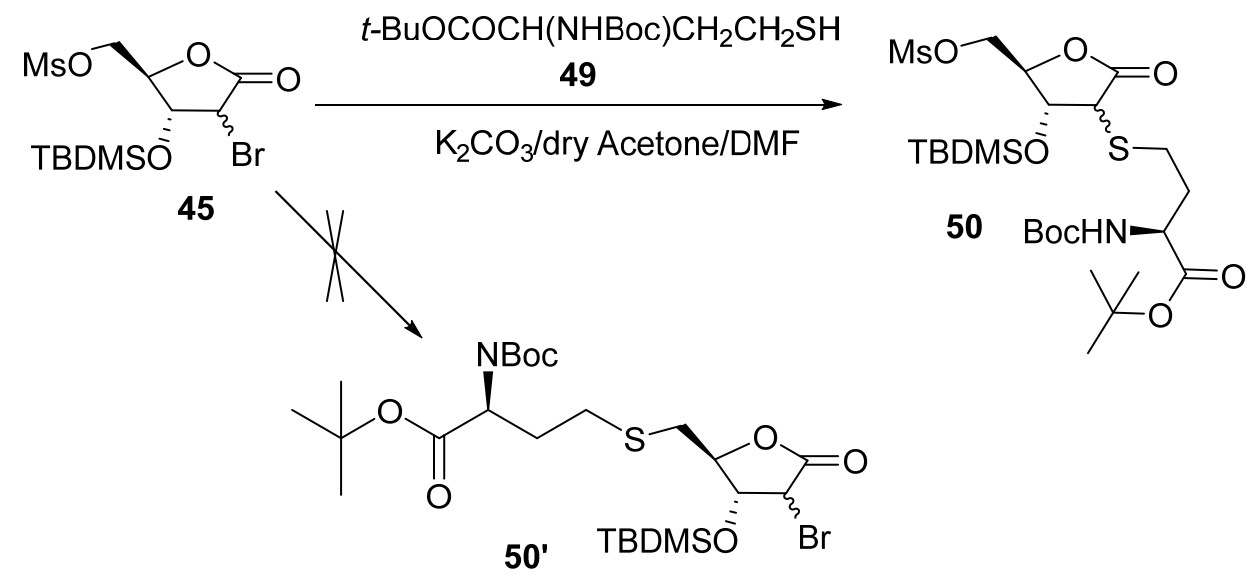

\section{Scheme 17. Coupling between the 5-O-mesyl-2-bromopentafuranose lactone and homocysteine thiolate.}

In order to optimize conditions for the reactions of bromo-lactone $\mathbf{4 5}$ with thiols, I carried out reactions between $\mathbf{4 5}$ and propylthiol instead of homocysteine under different conditions. Thus, treatment of $45(R / S, 60: 40)$ with 1 equiv. of the propylthiolate generated from propylthiol/LDA in $\mathrm{DMF}$ at $0{ }^{0} \mathrm{C}$ resulted in the formation of new product and disappearance of substrate 45. Purification of the crude reaction mixture on the silica column chromatography gave 1:1 mixture of the 2-S-propyl substituted 2thioribonolactone 50a (as 1:1 mixture of the arabino/ribo epimers) in overall yield of 61\% (Scheme 18). Structure for 50a was established based on spectroscopic data. Thus, 
${ }^{1} \mathrm{H}$ NMR spectra shows the singlet at $3.06 \mathrm{ppm}$ indicative of the presence of the mesyl group in addition to the characteristic peaks for the propylthiol moiety. On ${ }^{13} \mathrm{C} \mathrm{NMR}$, peaks at $171.47 / 172.74 \mathrm{ppm}$ indicate the presence of the carbonyl groups in the lactone 50a for the arabino-ribo epimers, while the lack of the bromine patterns $(\mathrm{M} / \mathrm{M}+2)$ on mass spectra analysis suggested the substitution at $\mathrm{C} 2$ and the loss of the bromine substituent. These results indicate that the secondary bromine at the $\alpha$-position to the carbonyl group in ribonolactones is a better leaving group than the mesylate at the primary hydroxyl group at C5.

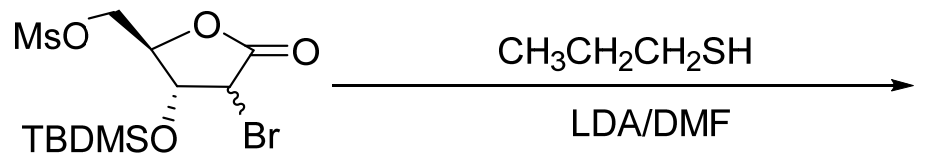

45

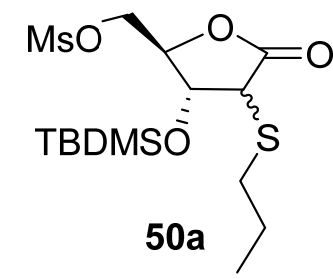

\section{Scheme 18. Model reaction of bromo-lactones with propylthiol}

\subsubsection{Synthesis of 2-deoxy-2-fluoro- $S$-ribosylhomocysteine analogues}

Two literature procedures were considered for the preparation of 2-fluoro-2deoxypentafuranosyl precursors (e.g., 60, Scheme 19) for the coupling with homocysteine. One approach was based on Fox's methodology ${ }^{131}$ presented in Scheme 19. It involves the fluorination of allose $\mathbf{5 3}$ to fluoroglucose $\mathbf{5 5}$ followed by an intramolecular rearrangement to yield to $\mathbf{6 0}$. The overall synthesis of $\mathbf{6 0}$, started with the oxidation of 1,2,5,6-di- $O$-isopropylidene- $\alpha$-D-glucofuranose 51 with chromium trioxide pyridine complex to afford its corresponding ketone 52. Reduction of $\mathbf{5 2}$ with sodium borohydride is expected to deliver hydride anion at the $\beta$-face ${ }^{132}$ of the sugar ring because of stereo-hindrance of the isopropylidene group present at $\mathrm{C} 1$ and $\mathrm{C} 2$ to give allose $\mathbf{5 3}$. 
Treatment of $\mathbf{5 3}$ with DAST resulted in a nucleophilic displacement of the hydroxyl group at $\mathrm{C} 3$ by fluoride with the inversion of configuration at $\mathrm{C} 3$ position to give 3fluoroglucose 54. ${ }^{133}$ Selective deprotection of the isopropylidene group from diol at C5 and C6 yielded $\mathbf{5 5}$ in high yield. Treatment of the latter with benzoyl chloride effected selective protection of the primary hydroxyl group at C6 to give 56. Subsequent removal of the isopropylidene group in 57 from $\mathrm{C} 1$ and $\mathrm{C} 2$ by treatment with $\mathrm{TFA} / \mathrm{H}_{2} \mathrm{O}$ gave 6-Obenzoyl-3-fluoroglucose 57 as an anomeric mixture $(\alpha / \beta, \sim 1: 3)$. Treatment of $\mathbf{5 7}$ with $\mathrm{NaIO}_{4}$ effected cleavage of cis-vicinal diol at $\mathrm{C} 1$ and $\mathrm{C} 2$ to give open sugar $\mathbf{5 8}$ which underwent simultaneous rearrangement involving a ring closure between the hydroxyl group at $\mathrm{C} 5$ with the aldehyde group generated at the former $\mathrm{C} 2$ (as depicted in 58) resulting in overall repositioning of fluorine atom from $\mathrm{C} 3$ to $\mathrm{C} 2$ leading to $\mathbf{5 9}$. Treatment of $\mathbf{5 9}$ with sodium methoxide yielded the fluoroarabinose $\mathbf{6 0}$.

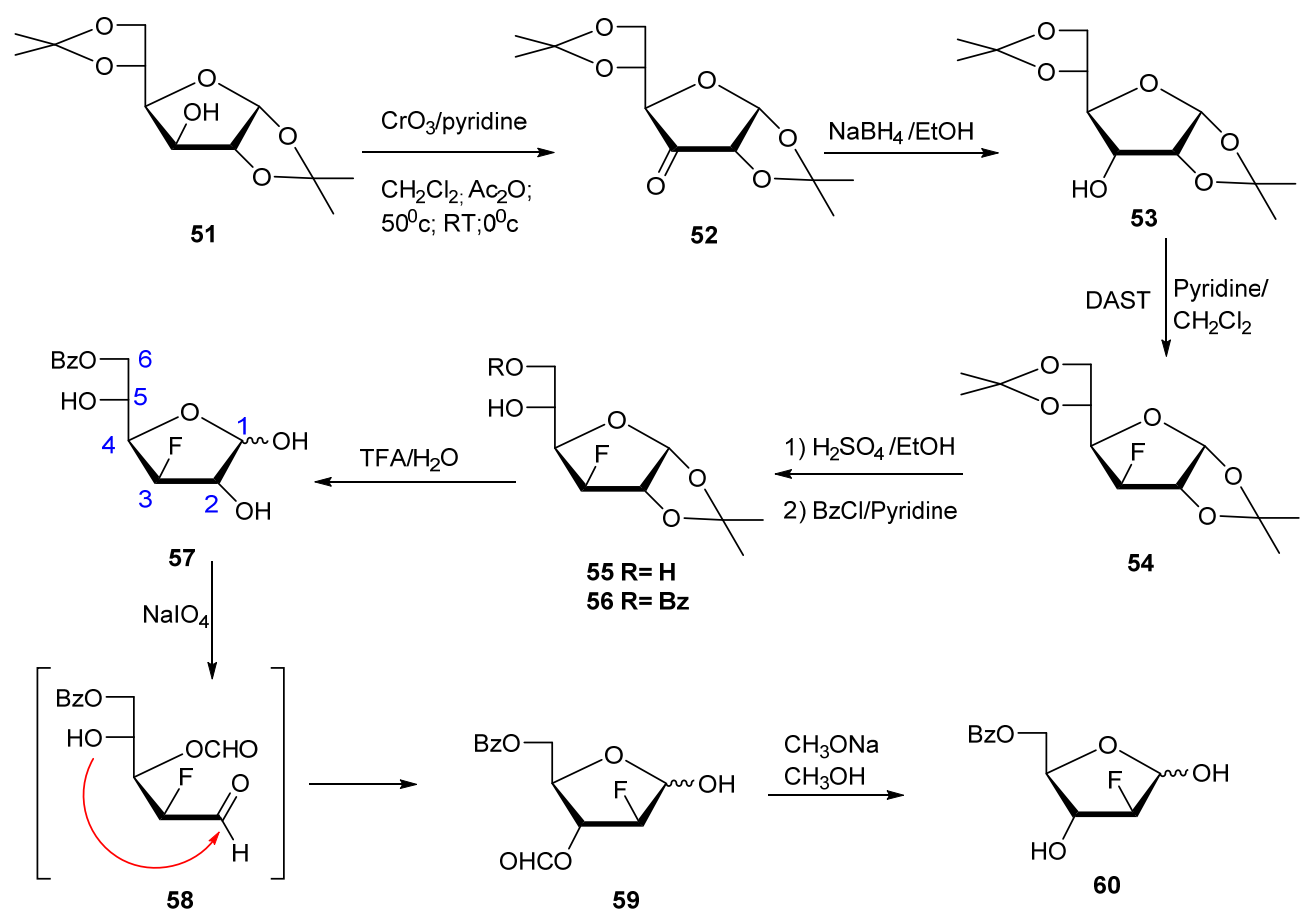

\section{Scheme 19. Synthesis of 2-deoxy-2-fluoro-a,D-arabinofuranose}


The second approach for the synthesis of 2-fluoropentofuranose was based on Cen and Sauve ${ }^{130}$ protocol. In this approach, the fluorination of the protected ribonolactone $\mathbf{4 2}$ is reported to give 2-fluoro-2-deoxy-ribo-lactone 62. The protocol involved enolization of lactone 42 with TMSOTf followed by fluorination of the resulting $\alpha$-silyl lactone $\mathbf{6 1}$ intermediate with NFSi ( $N$-fluorobenzene sulfonamide) to give 2-deoxyfluororibonolactone $\mathbf{6 2}$ as a single ribo-epimer. The stereoselectivity of the reaction is attributed to the diasteroselective formation of $\alpha$-silyl lactone $\mathbf{6 1}$ due to sterically bulky TBDMS that prevents the syn approach to the generated in situ enolate. In our hands, treatment of $\mathbf{4 2}$ with TMSOTf/NFSi gave fluorolactone $\mathbf{6 2}$ in lower yields than reported.

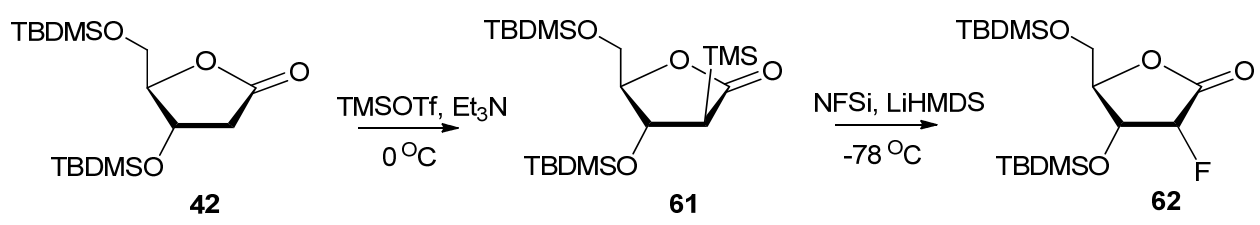

\section{Scheme 20. Synthesis of 2-Deoxy-2-fluororibonolactone}

Having in hand the fluoropentafuranoses sugar precursors $\mathbf{6 0}$ and 62, I focused on the preparation of the fluoro analogues with (a) 5-hydroxyl group activated for the replacement with homocysteine unit and (b) proper protection of other hydroxyl group which would be suitable for the coupling procedures which employs bases. Treatment of fluororibonolactone $\mathbf{6 2}$ with $\mathrm{TFA} / \mathrm{H}_{2} \mathrm{O}$ effected regioselective removal of the silyl protection group from the primary hydroxyl group at C5 to give 63. Subsequent mesylation of the primary hydroxyl at C5 gave 64; a suitable precursor for the displacement reaction with thiolate anion generated from the protected homocysteine. However, coupling of 64 with homocysteine 49 (in LDA/DMF) produced a complex reaction mixture from which I was not able to isolate a desired product $\mathbf{6 5}$. Attempted 
deprotection of the crude and contaminated 65 with TFA followed by RP-HPLC purification failed to yield the desired 2-[F]-SRH 36a (Scheme 21).

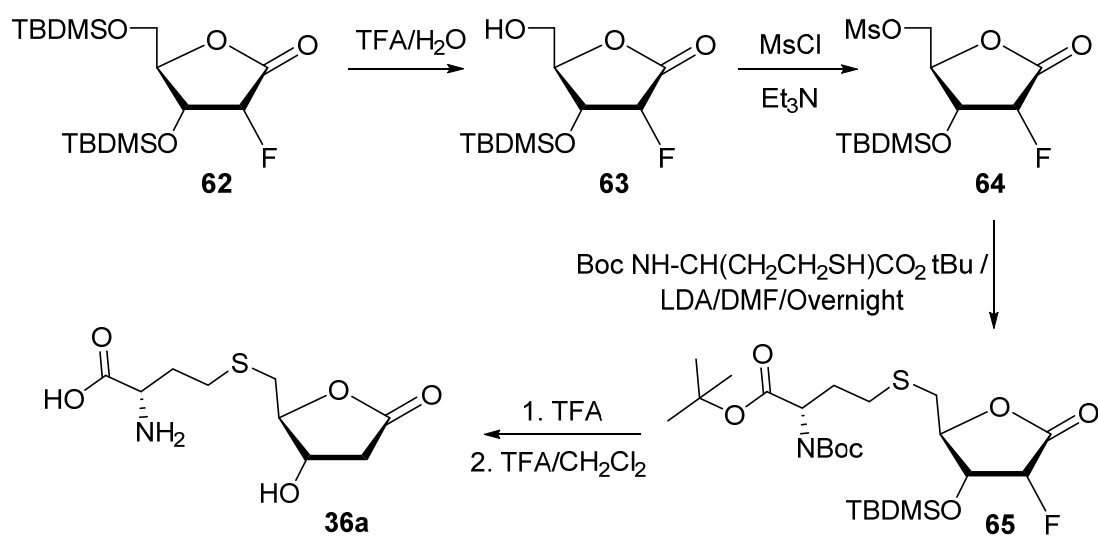

Scheme 21. The proposed plan for the synthesis of 2-deoxy-2 fluoro-Darabinofuranose.

\subsection{Design and synthesis of 4-C-alkyl/or aryl-S-ribosylhomocysteine analogues}

\subsubsection{Rationale for the synthesis of the 4-substituted SRH analogues:}

The substitution of the hydrogen at $\mathrm{C} 4$ of the 4-alkyl/or aryl-[SRH] derivatives by an alkyl or aryl group should impede the third tautomerization in the LuxS-catalyzed reaction and therefore prevent the elimination of the homocysteine molecule by the $\beta$ elimination process (Scheme 22). Thus, inhibition of DPD production should theoretically be shut down effecting also the QS communication in bacteria. The abstraction of $\mathrm{H}$-atom from $\mathrm{C} 4$ by the glutamine amino acid should not occur in the case of 4-C-substituted $[\mathrm{SRH}]$ derivative (complex 67a). I was also interested in checking the differences in the inhibitory activity based on the alkyl group length and chemical nature such as alkyl, vinyl, and aryl groups incorporated at $\mathrm{C} 4$ of ribose ring. The length of the alkyl group might also play an additional role in imposing the dimerization inhibition, 
especially since LuxS is a dimer protein. Thus, the alteration of the active site of the enzyme may lead to an allosteric inhibition. In theory, the longer the alkyl chain incorporated a more potent dimerization inhibition of LuxS should be observed by making the inhibitor at ease to reach both homodimer parts of the protein. The inhibitor might block one monomer leading to the alteration of the activity and as a consequence conformational changes of the second monomer.
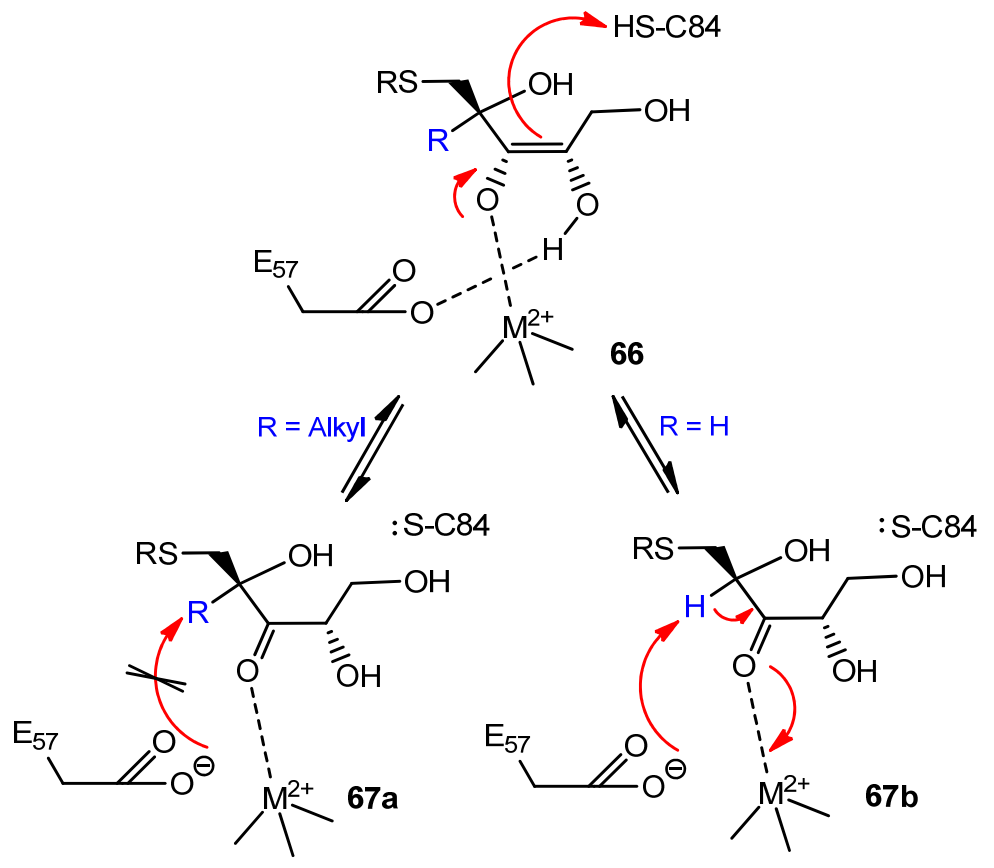

Scheme 22. A plausible inhibition of LuxS by 4-alkyl/or aryl-[SRH] substrate.

\subsubsection{Synthesis of 4-C-substituted SRH analogs:}

\subsubsection{Synthesis of 4-C-substituted ribono-1,4-lactones}

Preparation of 4-C-alkyl/aryl-S-ribosylhomocysteine analogues was envisioned to proceed through a keto-substrate $\mathbf{7 3}^{134}$ suitable for the alkylation with varying Grignard reagents. The ribitol-4-ulose $\mathbf{7 3}$ was prepared from ribose $\mathbf{6 8}$ employing the procedure

reported by Maddaford. ${ }^{134}$ Thus, treatment of ribose $\mathbf{6 8}$ with acetone in the presence of 
$\mathrm{H}_{2} \mathrm{SO}_{4}$ gave the isopropylidene protected ribofuranose 69 (Scheme 23). ${ }^{135}$ Tritylation of the primary 5-hydroxyl group 69 with $\mathrm{TrCl}$ yielded $\mathbf{7 0}$. Reduction of the hemiacetal $\mathbf{7 0}$ with $\mathrm{NaBH}_{4}$ provided the acyclic ribitol 71. Subsequent silylation of 71 with TBDMSCl effected regioselective protection of the primary hydroxyl group at $\mathrm{C} 1$ to give $\mathbf{7 2}$. Oxidation of the secondary hydroxyl group at $\mathrm{C} 4$ of $\mathbf{7 2}$ with Dess-Martin periodinane reagent provided the 4-ulose derivative $\mathbf{7 3}$, as a suitable precursor for the subsequent alkylation reactions with Grignard-based reagents. The overall yield for the conversion of the ribose $\mathbf{6 8}$ to ribitol-4-ulose 73 was $75 \%$ (5 steps).

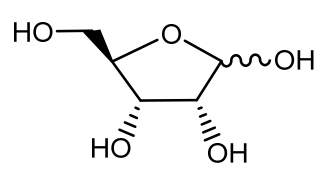

68

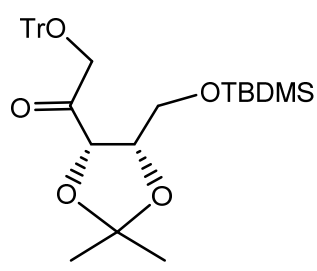

73
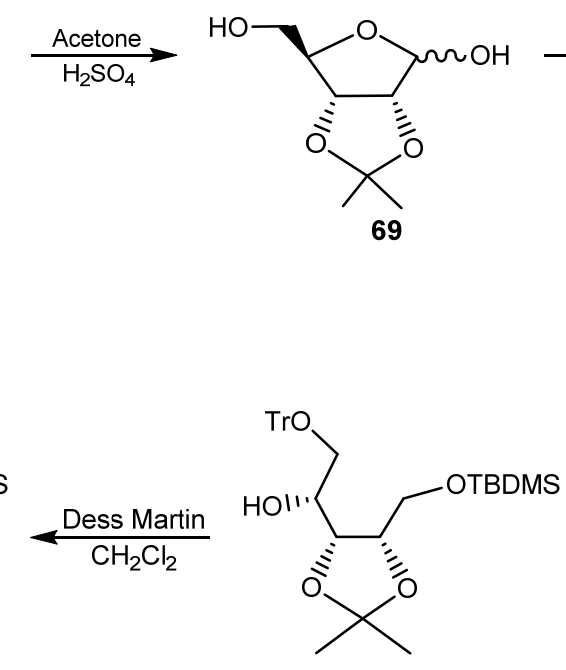

72

69
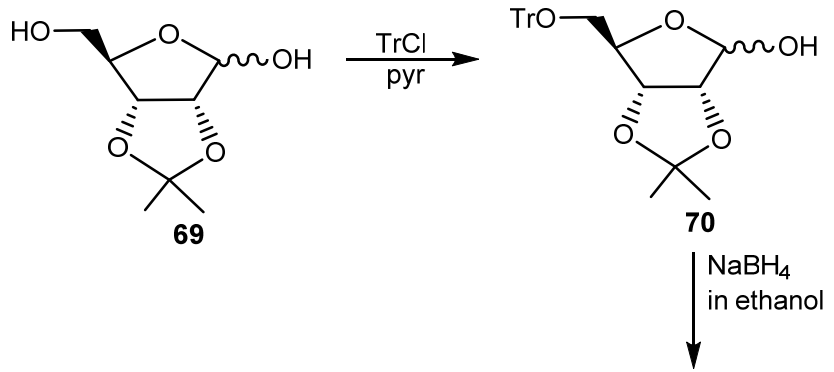

Scheme 23. Preparation of the precursors for the synthesis of 4- $C$-alkyl-SRH analogs. ${ }^{134}$

Diastereoselective addition of different Grignard reagents to ketone $\mathbf{7 3}$ was accomplished following Pryde and coworkers procedure. ${ }^{134}$ Alkyl, vinyl and aryl substituents were successfully inserted at the 4-position of the ribose ring to give a variety of 4-substituted ribitols $\mathbf{7 4 a - e}$ (Scheme 24). Thus treatment of ketone $\mathbf{7 3}$ with methylmagnesium bromide at $-78{ }^{\circ} \mathrm{C}$ for 15 min produced the corresponding $4-C$-methyl- 
ribitol 74a in $88 \%$ yield as single isomer after purification on silica gel column. The ${ }^{1} \mathrm{H}$ and ${ }^{13} \mathrm{C}$ NMR spectra were diagnostic for the structure of 74a. On the ${ }^{1} \mathrm{H}$ NMR spectrum, a new singlet for the methyl group at $1.35 \mathrm{ppm}$ was observed along with the disappearance of the signal for $\mathrm{H} 4$ and simplification of the multiplets signals for $\mathrm{H} 5$ and H5' to doublets (as compared to 72) with geminal coupling constants between them of 8.7 Hz. Addition of hexylmagnesium bromide or octylmagnesium bromide to ketone $\mathbf{7 3}$ gave the corresponding 4-C-hexyl and 4-C-octyl ribitols $\mathbf{7 4 b}$ and $\mathbf{7 4 c}$ in $64 \%$ and $60 \%$ isolated yields, respectively. Also addition of the vinyl magnesium bromide to ketone $\mathbf{7 3}$ proceeded smoothly to give the $4-C$-vinyl-ribitol $\mathbf{7 4 d}$ in $55 \%$ yield as a single isomer. The characteristic pattern of the peaks for the terminal monosubstituted olefin was observed in the ${ }^{1} \mathrm{H}$ NMR spectrum of $\mathbf{7 4 d}$. The addition of 4-methoxyphenylmagnesium bromide to ketone $\mathbf{7 3}$ also proceeded efficiently to provide $4-C$-aryl ribitol $\mathbf{7 4 e}$ in $96 \%$ yield.

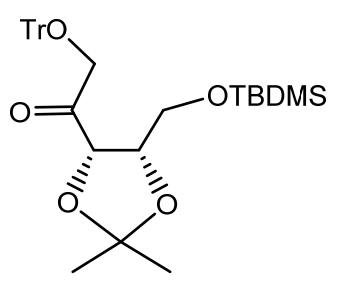

73

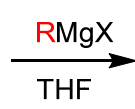$$
\text { THF }
$$

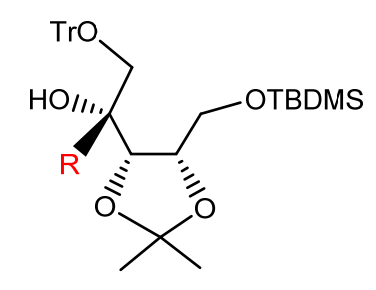

74a $\mathrm{R}=$ methyl

74b $R=$ hexyl

74c $R=$ octyl

74d $R=$ vinyl

74e R = 4-methoxyphenyl

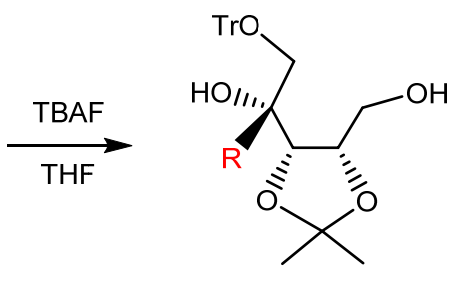

75a $\mathrm{R}=$ methyl

75b $\mathrm{R}=$ hexyl

75c $\mathrm{R}=$ octyl

75d $R=$ vinyl

75e R = 4-methoxyphenyl

\section{Scheme 24: Diasteroselective addition of Grignard reagents to the 4-ketoribitol precursors.}

The stereoselective formation of 4-C-substituted ribitols $\mathbf{7 4}$ can be explained by the Cram's rule for the chelation of heteroatom on the $\alpha$-carbon to a carbonyl group (Scheme 25). The Grignard reagent addition to the ribitol-4-ulose $\mathbf{7 3}$, which is an $\alpha$-alkoxy ketone, 
proceeds via a 5-membered cyclic chelate 73a. Crams's rule stated that nucleophilic addition with either organometallic or metal hydride reagent leads to chelation control in diastereoselective carbonyl reduction. The carbonyl is flanked by two smaller groups $\mathrm{S}$ and M. The larger group L is eclipsed to the carbonyl group. The metal part gets complexed with the carbonyl group and the alkanide carbanion is transferred to the trigonal carbon from the side of small group in preference to medium group or in the antifashion to the $\alpha$-hydroxyl group at C3.
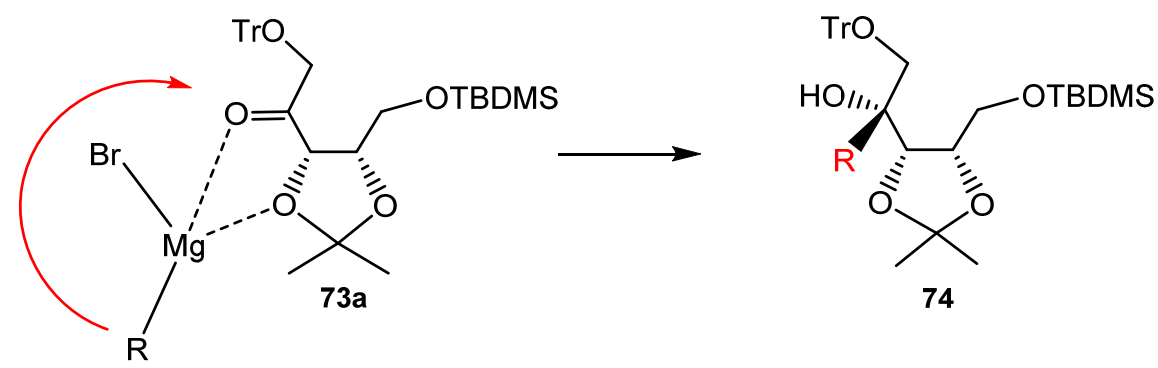

\section{Scheme 25. Proposed model for the diastereoseletive addition of the Grignard reagent to ketone 73 .}

Treatment of 4-C-methylribitol 74a with TBAF in THF at $0{ }^{\circ} \mathrm{C}$ for 30 min effected selective removal of the TBDMS protection group to give the ribitol $\mathbf{7 5 a}$ in $77 \%$ yield. Analogous desilylation of $\mathbf{7 5 b}$-e produced the corresponding 4-C-substituted ribitols in 77-87\% yield for $\mathbf{7 5 b}-\mathbf{d}$ and $59 \%$ yield for $\mathbf{7 5 e}$ having a primary hydroxyl group at C1 and a tertiary hydroxyl group at C3.

With the 4-C-substituted ribitols $\mathbf{7 5}$ in hands, I investigated few options for the ring closure in order to prepare the suitable 4-substituted ribose precursors for the coupling with Hcy. The first option involved oxidation of the primary hydroxyl at $\mathrm{C} 1$ in $\mathbf{7 5}$ to the carboxylic acid with the concomitant ring closure to the corresponding ribono-1,4lactone. Thus, the Ley-Griffith oxidation of the primary hydroxyl group at $\mathrm{C} 1$ in $\mathbf{7 5 a}$ with 
tetrapropylammonium perrenthenate (TPAP)/ $N$-methylmorpholine $N$-oxide (NMO) followed by the intramolecular ring closure gave the corresponding 4-C-methyl ribono1,4-lactone $\mathbf{7 6 a}$ in $80 \%$ yield after silica gel column chromatography. The oxidation of 75a occurred with catalytic amount of TPAP in the presence of a stoichiometric amount of co-oxidant NMO that regenerates the catalyst. The ${ }^{1} \mathrm{H}$ and ${ }^{13} \mathrm{C}$ NMR spectra were diagnostic for the structure of 76a. On the ${ }^{1} \mathrm{H}$ NMR spectrum, the disappearance of the signals for $\mathrm{H} 1$ and $\mathrm{H} 1$ ' and simplification of the signal for $\mathrm{H} 2$ to a doublet with vicinal coupling constants of $5.6 \mathrm{~Hz}$ to $\mathrm{H} 3$ was indicative of the oxidation of the hydroxyl group at $\mathrm{C} 1$ and the formation of lactone. The formation of lactone was also supported by the appearance of a peak at $172.07 \mathrm{ppm}$ for the carbonyl carbon at $\mathrm{C} 1$ on ${ }^{13} \mathrm{C}$ NMR spectrum.

Oxidation of 4-C-hexyl and 4-C-octyl ribitols $\mathbf{7 5 b}$ or $\mathbf{7 5 c}$ with TPAP/NMO also proceeded smoothly to give the 4-C-hexyl- and $4-C$-octylribonolactones $\mathbf{7 6} \mathbf{b}$ and $\mathbf{7 6} \mathbf{c}$ in 90-95\% yield as single isomers. On ${ }^{1} \mathrm{H}$ NMR spectra, the appearance of the doublet of $\mathrm{H} 2$ at $4.1 \mathrm{ppm}$ with a coupling constant of $5.6 \mathrm{~Hz}$ was indicative of the ring closure and formation of lactones $\mathbf{7 6 b}$ or $\mathbf{7 6} \mathbf{c}$ (Scheme 26). Similarly to $\mathbf{7 6 a}$ a new peak at 174.41 ppm appeared on ${ }^{13} \mathrm{C}$ NMR proving the presence of the carbonyl group at $\mathrm{C} 1$. However, depending on the reaction workup conditions, especially for the ribonolactones with long alkyl chain, the open form of the ribonolactones $7^{\prime} \mathbf{b}$ and $\mathbf{7 6}^{\prime} \mathbf{c}$ with the free carboxylic group at $\mathrm{C} 1$ were detected. During the oxidation of $75 \mathrm{c}$ to $76 \mathbf{c}$ the ratio of $76 \mathbf{c}$ to $76 \mathbf{c}$ in equilibrium was found to be $3: 1$. The ${ }^{1} \mathrm{H}$ NMR spectrum of the equilibrium mixture of the ribonolactone $\mathbf{7 6} \mathbf{c}$ and its opened carboxylic acid form $\mathbf{7 6} \mathbf{c}$ have two distinctive sets of peaks of the ribosylic protons $\mathrm{H} 2, \mathrm{H} 3, \mathrm{H} 5$ and $\mathrm{H} 5$ ' (see experimental part). The MS spectra which differ by 18 units $\left(\mathrm{H}_{2} \mathrm{O}\right)$ were indicative of ring opening of $\mathbf{7 6}^{\prime} \mathbf{c}$ to $\mathbf{7 6} \mathbf{c}$. 


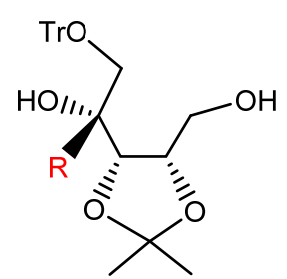

75

75a $R=$ methyl

75b $\mathrm{R}=$ hexyl

75c R = octyl

75d $R=$ vinyl

75e $R=$ aryl

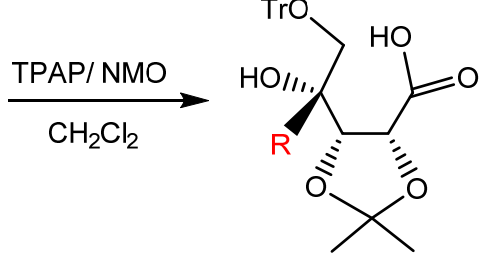

76'b R = hexyl

76 'c R = octyl

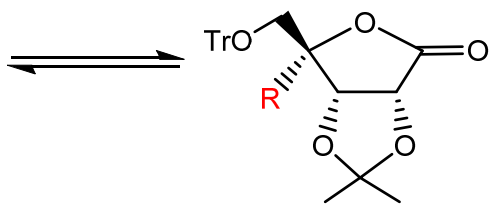

76

76a $R=$ methyl

76b $\mathrm{R}=$ hexyl

76c $R=$ octyl

76d $R=$ vinyl

76e $\mathrm{R}=$ aryl

\section{Scheme 26. Oxidation of 4- $C$-substituted ribitols with TPAP and NMO}

The oxidation of the riitols $\mathbf{7 5}$ and intramolecular ring closure to lactone $\mathbf{7 6}$ is believed to be initiated by the attack of the primary hydroxyl group at $\mathrm{C} 1$ on the ruthenium oxidant. ${ }^{136}$ The resulting oxide 77 further abstracts the hydrogen atom from $\mathrm{C} 1$ to form aldehyde 78 (Scheme 27). Hydration of the aldehyde to $\mathbf{7 9}$ and the repetition of the oxidation cycle leads to the ring closure and formation of the 4-C-alkylribonolactone 76, which occurred by a nucleophilic attack of the $\mathrm{C} 4$ hydroxyl group on $\mathrm{C} 1$, as depicted in complex 80, leading to the release of the ruthenium molecule.

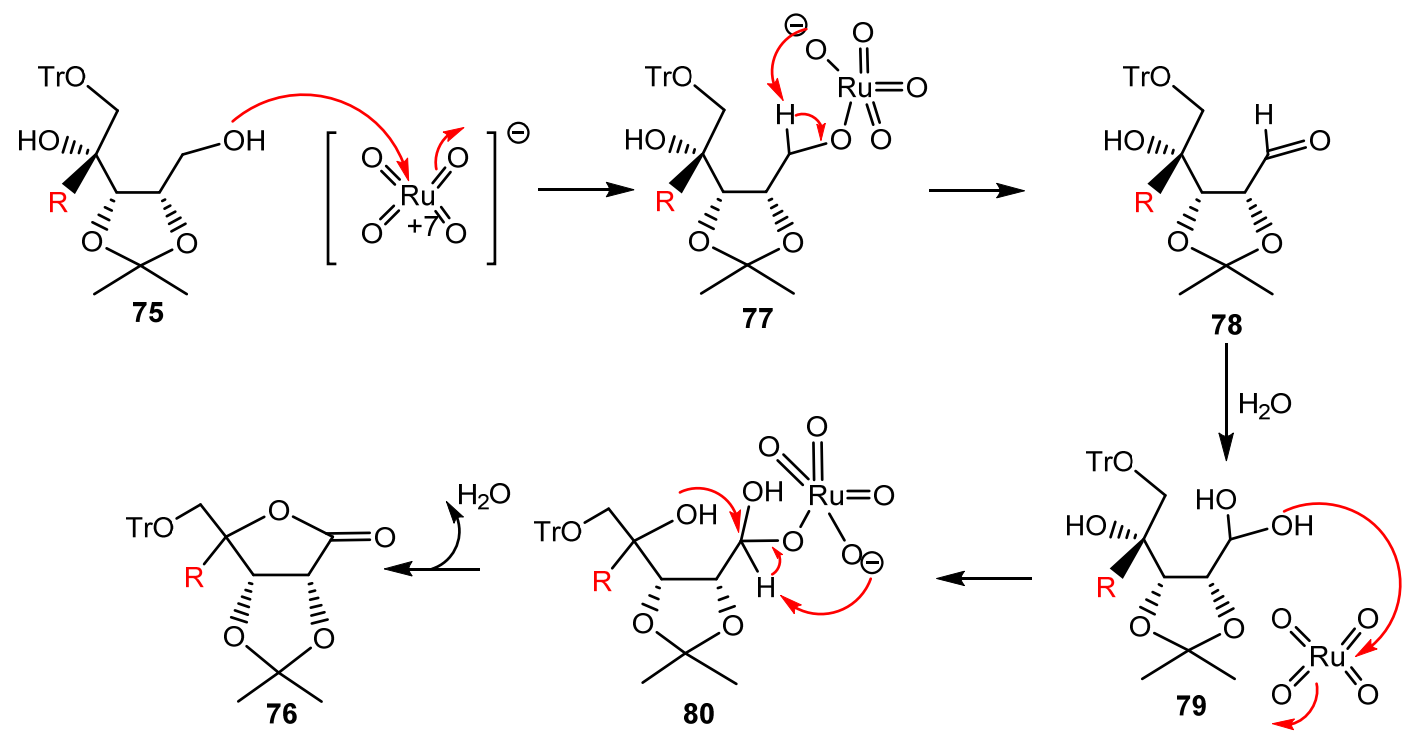

Scheme 27: Mechanism of oxidation with NMO/TPAP and ring closure to ribonolactone. 
In a second approach towards ring closure of the 4- $C$-substituted ribitols 75, I examined the possibility of the oxidation of the primary hydroxyl at $\mathrm{C} 1$ to an aldehyde, which should subsequently cyclizes to the hemiacetal $\mathbf{8 1}$ via the intramolecular ring closure (Scheme 28). The advantage of this method is that it leads to an already reduced sugar 81 instead of a lactone precursor 76. However, attempts to oxidize $\mathbf{7 5 b}$ or $\mathbf{7 5 c}$ employing Swern reaction condition (oxalic chloride/DMSO/Et ${ }_{3} \mathrm{~N}$ ) gave a complex reaction mixture with low yields and hemiactal $\mathbf{8 1}$ has never been isolated from the reaction mixture in a pure form (Scheme 28).

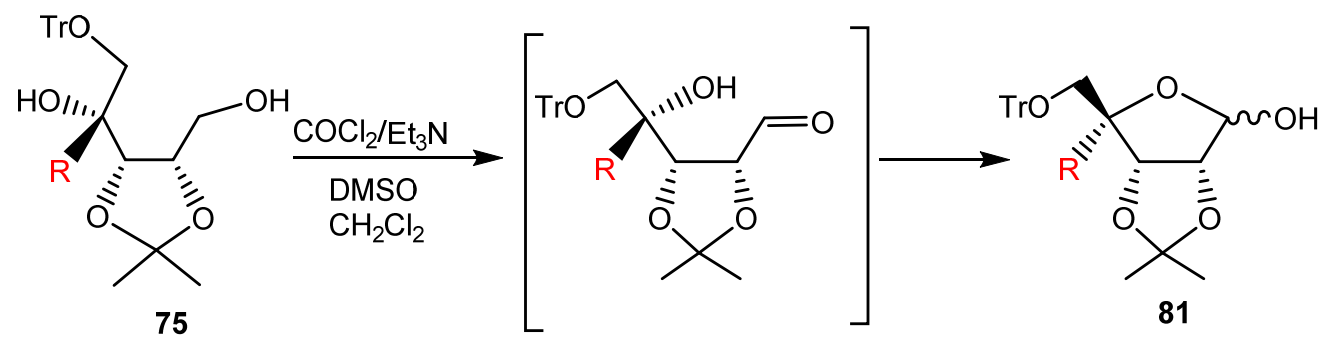

\section{Scheme 28. Attempted synthesis of hemiacetals 81 by Swern oxidation.}

\subsubsection{Coupling of 4-C-substituted 1,4-ribonolactones and Hcy}

With the 4-C-substituted ribonolactones 76a-e in hands, I considered options to prepare the suitable 4-substituted ribose precursors for coupling with Hcy (Scheme 29). Thus, detritylation of 76a $\left(16 \mathrm{~h}\right.$, rt) with $\mathrm{TFA} / \mathrm{CH}_{2} \mathrm{Cl}_{2}$ gave 84a in $66 \%$ yield after purification on silica gel column chromatography. On ${ }^{1} \mathrm{H}$ NMR spectrum of 84a, the absence of the aromatic hydrogens between 7.25-7.38 ppm was indicative of the trityl group removal. HRMS showed a molecular ion $[\mathrm{M}+\mathrm{Na}]^{+}$peak at 225.0734 verifying a molecular formula $\mathrm{C}_{9} \mathrm{H}_{14} \mathrm{O}_{5} \mathrm{Na}^{+}$.

Analogous treatment of the hexyl 76b and octyl 76c with TFA (5 h, rt) gave 84b and $\mathbf{8 4 c}$ in $80 \%$ and $75 \%$ yields, respectively. Interestingly, when the reaction mixture (76b 
$\rightarrow \mathbf{8 4 b}$ ) was left stirring overnight, a second product was formed in a ratio of 1:1 to $\mathbf{8 4 \mathbf { b }}$. The new product is believed to be the corresponding 4-C-hexylribopyranose $\mathbf{8 8 b}$ formed via the ring opening of the ribofuranose $\mathbf{8 4 b}$ and the subsequent ring closure with $\mathrm{C} 5$ hydroxyl group. ${ }^{1} \mathrm{H}$ NMR and COSY spectra of the 1:1 mixture of $\mathbf{8 4 \mathbf { b }} / \mathbf{8 8 \mathbf { b }}$ showed two sets of distinctive peaks. A doublet for $\mathrm{H} 2$ of $\mathbf{8 8 b}$ was shifted downfield from $4.55 \mathrm{ppm}$ to $4.22 \mathrm{ppm}$. Also, the vicinal coupling constant between $\mathrm{H} 2$ and $\mathrm{H} 3$ was changed from $5.6 \mathrm{~Hz}$ in $\mathbf{8 4 \mathbf { b }}$ to $2.5 \mathrm{~Hz}$ in $\mathbf{8 8 \mathbf { b }}$. The magnitude of the geminal coupling constants between protons $\mathrm{H} 5$ and $\mathrm{H}^{\prime}$ in $\mathbf{8 8 b}(12.7 \mathrm{~Hz})$ were larger than the one observed in $\mathbf{8 4 \mathbf { b }}$ $(11.6 \mathrm{~Hz})$. Treatment of the vinyl analogue $\mathbf{7 6 d}$ with TFA $(5 \mathrm{~h}, \mathrm{rt})$ also gave detritylated ribonolactone 84d but in only $35 \%$ yield after purification on silica gel column chromatography. Similarly, 76e was converted to $84 \mathbf{e}$ with $60 \%$ yield. HRMS spectra of compounds 84a to 84e mass spectra were consistent with the theoretical molecular mass of respective compounds, which verified that detrytilation occurred.

In the next step, I considered reduction of the $4-C$-substituted fully protected $\mathbf{7 6} \mathbf{b}$ or detrytilated 84c ribofuranoses with $\mathrm{LiEtBH}_{3}$ as a valuable approach for the synthesis of the cyclic hemiacetal 86, especially since our previous attempts to convert ribitol $\mathbf{7 5}$ to hemiacetal 81 employing the Swern reaction were unsuccessful as described above. Thus, treatment of the 4-C-hexyl 76b with $\mathrm{LiEtBH}_{3}$ in $\mathrm{CH}_{2} \mathrm{Cl}_{2}$ at $0{ }^{\circ} \mathrm{C}$ for 30 min gave the corresponding hemiacetal $\mathbf{8 6 \mathbf { b }}$ as an anomeric mixture $(\alpha / \beta, 1: 3)$ in $54 \%$ yield after column chromatography. The chemical shift and vicinal ${ }^{3} J_{\mathrm{H} 1-\mathrm{H} 2}$ coupling constant was diagnostic for the composition of $\alpha / \beta$ anomers. For the $\alpha$-isomer the signal for H1 was observed as a doublet of a doublet with splitting to $\mathrm{H} 2$ and $\mathrm{OH}$ group at $\mathrm{C} 1$ with respective coupling constants of $4.2,11.6 \mathrm{~Hz}$. For the $\beta$-isomer, the signal for $\mathrm{H} 1$ 
appeared as doublet with coupling constant of $8.5 \mathrm{~Hz}$ to hydroxyl group only. In addition, $\mathrm{H} 2$ appeared as a doublet of doublet with couplings to both $\mathrm{H} 1$ and $\mathrm{H} 3$ in the $\alpha$-isomer, whereas for the $\beta$-isomer, the signal fo $\mathrm{H} 2$ is simplified to a doublet with a coupling constant of $6.0 \mathrm{~Hz}$ to $\mathrm{H} 3$ only.

Analogous treatment of the 4-C-octyl $\mathbf{8 4} \mathbf{c}$ with $\mathrm{LiEtBH}_{3}$ gave the hemiacetals $\mathbf{8 6} \mathbf{c}$ as an anomeric mixture: 86c $(\alpha / \beta, 1: 1 ; 63 \%)$ after column chromatography (Scheme 29). Attempted conversion of the hemiacetals $86 \mathbf{b}$ and $\mathbf{8 6 c}$ to the respective methyl riboside acetals 87b and 87e upon treatment with either (i) $\mathrm{MeOH} / \mathrm{acetone}$ for $86 \mathbf{b}$ or (ii) pTSA/MeOH for $86 \mathbf{c}$ failed to produce the desired acetal $87 \mathbf{b}$ or $87 \mathbf{c}$. Since acetals are stable in basic conditions, they were envisioned as good substrates (after activation of the 5-hydroxyl group) for the condensation with Hcy which required basic conditions.

In the next approach for the coupling of 4-C-alkyl riboses with Hcy, I turned my attention to the direct coupling of ribono-1,4-lactones with Hcy as a plausible alternative. Thus, treatment of $84 a, 84 b, 84 c$ and $84 \mathrm{e}$ with mesyl chloride gave the corresponding 5$O$-mesylribonolactone $\mathbf{8 5 a}$ with $63 \%$ yield, $\mathbf{8 5 b}$ and $\mathbf{8 5 c}$ with approximately $50 \%$ yield, and $\mathbf{8 5 e}$ with $83 \%$ yield after column chromatography. On ${ }^{1} \mathrm{H}$ NMR spectra, a singlet at $3.01 \mathrm{ppm}$ was diagnostic for the presence of the mesyl group at C5 in all compounds. A shift of H5 and H5' signals from 3.75 and 3.85 ppm in $\mathbf{8 4 b}$ and $\mathbf{8 4 c}$ to 4.20 and $4.32 \mathrm{ppm}$ in $\mathbf{8 5 b}$ and $85 \mathrm{c}$ indicated the formation of the mesylate ester. Similarly, a comparable downfiled shift of $\mathrm{H} 5$ and $\mathrm{H} 5$ ' occurred on ${ }^{1} \mathrm{H}$ NMR spectra in 85a and 85e as a result of the introduction of methylsulfonate EWG. 


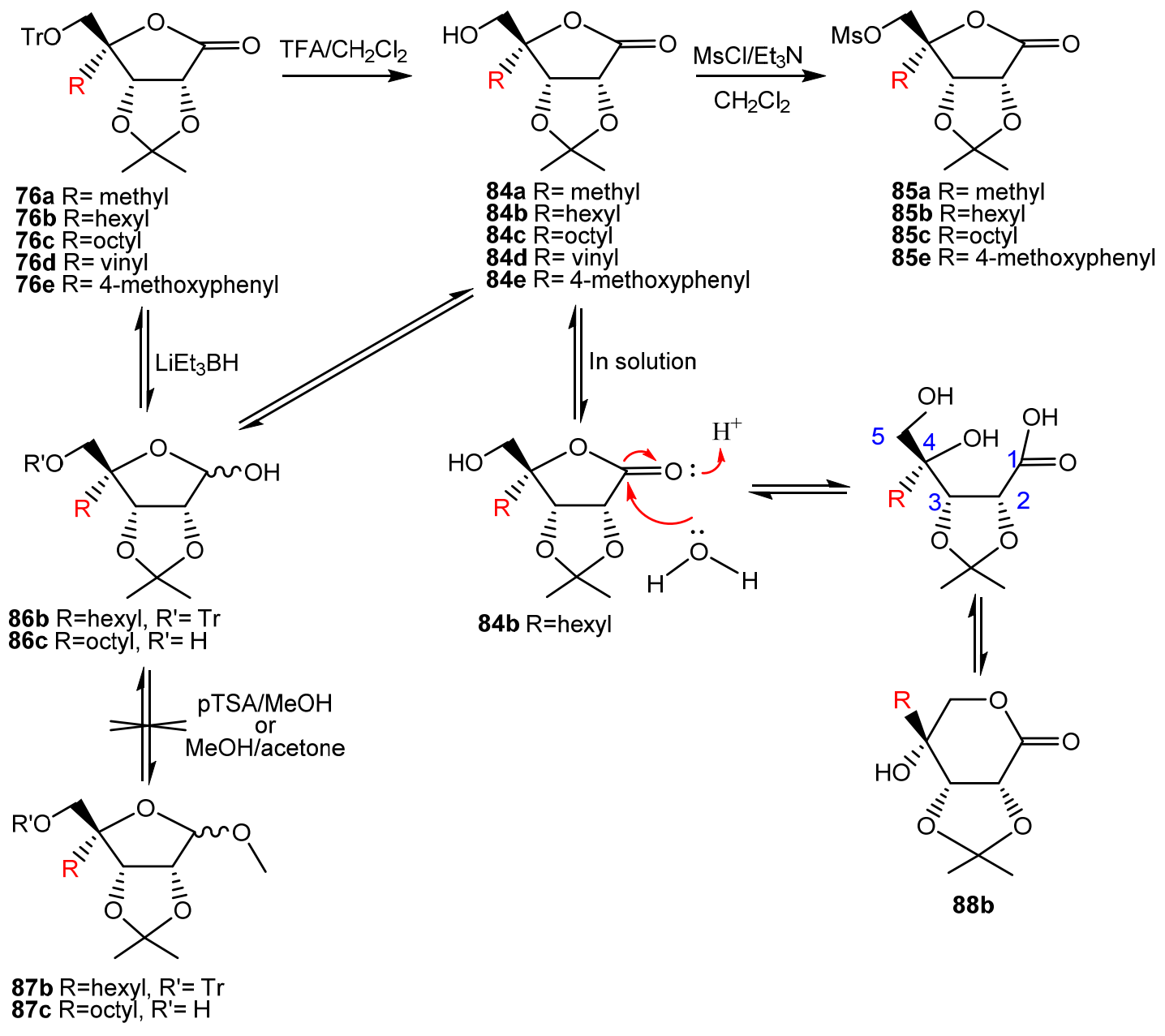

\section{Scheme 29. Different strategies of 4-substituted ribose precursors}

Nucleophilic displacement of the mesylate in $\mathbf{8 5 b}$ with Hcy thiolate (3 equiv.), generated from the protected L-homocysteine 49 and LDA in DMF, afforded 89b in 65\% yield after silica gel column purification (Scheme 30). The structure of the 89b was established by the spectroscopic techniques. HRMS (AP-ESI) proved the molecular formula of $\mathrm{C}_{27} \mathrm{H}_{48} \mathrm{NO}_{8} \mathrm{~S}^{+}$. Analogous coupling of 85c with Hcy gave 89c $(\sim 30 \%)$ contaminated with the protected Hcy 49 substrate $(\sim 50 \%)$ which was used in excess in the reaction. The upfield shift of $\mathrm{H} 5$ and H5' signals on ${ }^{1} \mathrm{H}$ NMR spectra from 4.20 and $4.32 \mathrm{ppm}$ in $\mathbf{8 5 b}$ and $85 \mathbf{c}$ to 2.72 and 2.80 in $89 \mathbf{b}$ and $89 \mathbf{c}$ indicated the formation of the 
new C-S bond. The 4-C-aryl mesylate 85e was coupled with homocysteine thiolate 49 to give 89e with $48 \%$ yield.

Treatment of the crude 89c with TFA effected global deprotection of all acid label groups to give crude 90c. Purification of the mixture on Sepak column gave 4-C-octyl$\mathrm{SRH}$ lactone 90c as a $95 \%$ pure product in $15 \%$ overall yield from $\mathbf{8 5 c}$. The molecular formula for 90c $\left[\mathrm{C}_{17} \mathrm{H}_{31} \mathrm{NO}_{6} \mathrm{~S}^{+}\right]$was verified by HRMS. Deprotection of $\mathbf{8 9 b}$ with TFA gave 90b in $60 \%$ yield after HPLC purification. Analogous deprotection of 4-C-4methoxyphenyl SRH lactone 89e with TFA and its purification gave 90e. The molecular formula for $90 \mathbf{b}\left[\mathrm{C}_{15} \mathrm{H}_{27} \mathrm{NO}_{6} \mathrm{~S}^{+}\right]$and $90 \mathbf{e}\left[\mathrm{C}_{16} \mathrm{H}_{21} \mathrm{NO}_{7} \mathrm{~S}^{+}\right]$were verified by HRMS.

Treatment of $\mathbf{8 9 b}$ with $\mathrm{LiEt}_{3} \mathrm{BH} / \mathrm{THF}$ (5 equiv.) in $\mathrm{CH}_{2} \mathrm{Cl}_{2}$ at $0{ }^{0} \mathrm{C}$ effected reduction of the lactone to the hemiacetal yielding protected SRH analogue $91 \mathbf{b}$ as a mixture of $\alpha / \beta$ anomers (1:4). Deprotection of $\mathbf{9 1 b}$ with TFA and $\mathrm{TFA} / \mathrm{H}_{2} \mathrm{O}$ effected removal of all the protection groups to give anomers of 4-C-hexyl-SRH 92b. Similarly, deprotection of 91e yielded 92e. Subjection of $89 \mathbf{e}$ to the reduction and deprotection sequence afforded $92 \mathbf{e}$. Alternatively, the deprotected lactone 90c was reduced with $\mathrm{LiEt}_{3} \mathrm{BH} / \mathrm{THF}$ to afford hemiacetal 92c. 


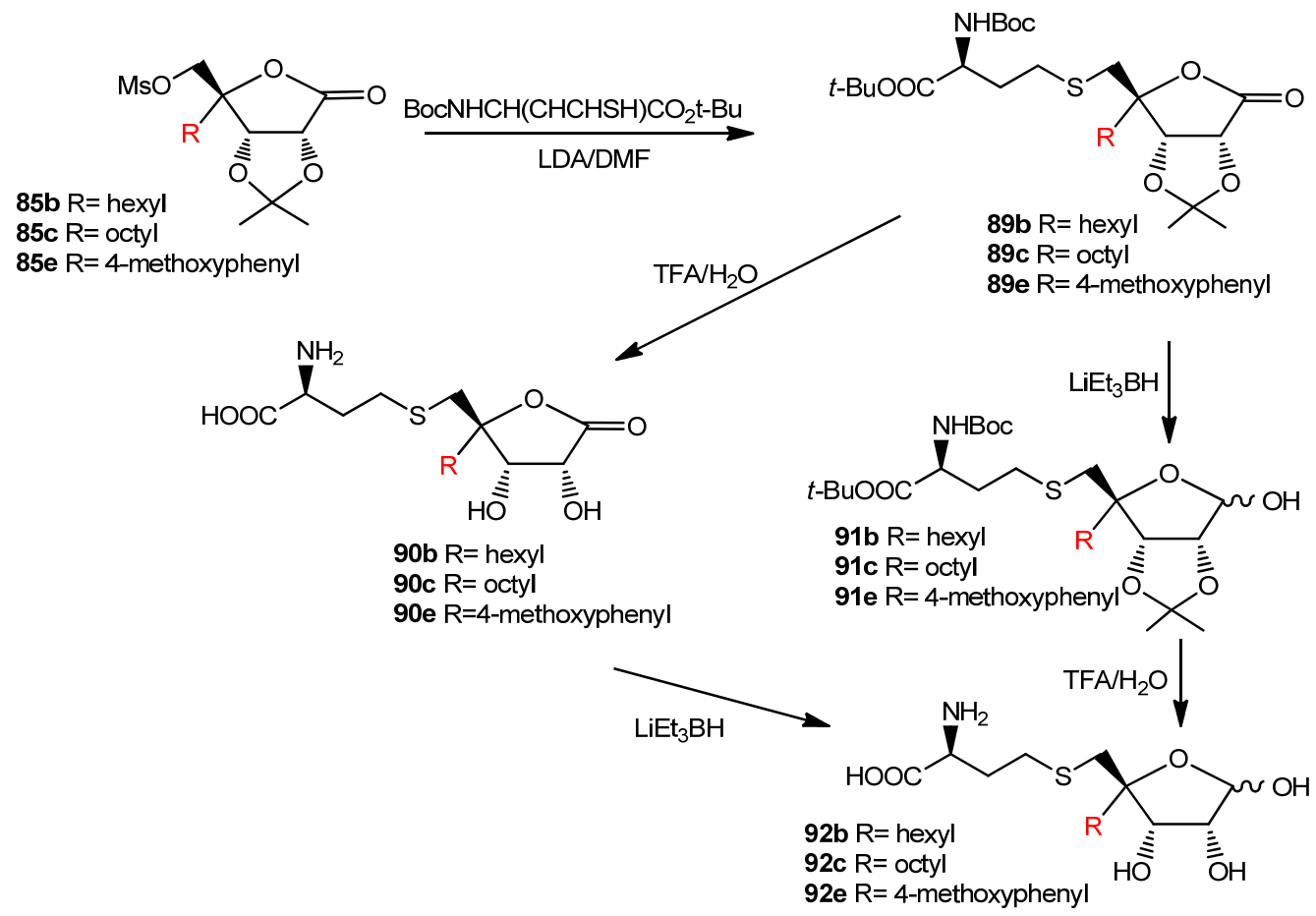

\section{Scheme 30. Coupling of mesyl-ribonolactone derivative with homocysteine thiolate} and deprotection

\subsection{Design and synthesis of 4 -[thia]-S-ribosylhomocysteine analogues}

Replacement of the sugar ring oxygen by sulfur provides close mimics of natural sugars, it is noteworthy, that the sulfur atom is larger and more polarizable than oxygen and the carbon -sulfur bond is longer (C-S, $0.182 \mathrm{~nm}$ vs C-O, 0.143nm), weaker and less polar than a carbon-oxygen bond (electronegativities on the Sanders scale: O, 3.65; S, 2.96; C, 2.75). ${ }^{137}$ Such differences are responsible for significant alterations in the anomeric effect, conformational behavior, chemical reactivity, molecular recognition by proteins, and metabolic stability of thiosugars analogues in comparison with their oxygen counterparts. Since only the open aldehyde form of SRH is catalytically active, I was interested in the effect of the sulfur substitution on the ring opening, especially since previously has been shown that for 4-[aza]-SRH analogue acted as time-dependent 
inhibitors of LuxS as discussed in section 1.1.5 (Scheme 27 and 28). The existence of the thiohemiacetals in equilibrium with open aldehyde form is expected for 4-thioriboses under basic and/or acidic conditions. ${ }^{138}$ In my efforts to synthesize thiohemiacetal 39 (Scheme 29), I explored the possibility of employing thioribosyl fluorides as precursors for the preparation of the $O, S$-acetals analogues of SRH.

The synthetic approach started from 1-deoxy thiosugar precursor 93, which was prepared from D-ribose or gulonolactone following the procedures of Mastuda ${ }^{139}$ or Jeong. ${ }^{140,141}$ Thus, acetylation of the 5-hydroxyl group in $\mathbf{9 3}$ gave 94 in $95 \%$ yield (Scheme 29). Subsequent oxidation afforded sulfoxides 95 as a $4: 1$ mixture of diastereomers at sulfur. Treatment of sulfoxide 95 with $\mathrm{DAST} / \mathrm{SbCl}_{3}$ combination ${ }^{142}$ resulted in fluoro-Pummerer rearrangement to give $\alpha$-fluoro thioether $96(\alpha / \beta \sim 1: 9)$ in $65 \%$ combined yield after flash column chromatography. Reactions of sulfide 94 with $\mathrm{DAST} / \mathrm{SbCl}_{3}{ }^{143}$ also produced thioribosyl fluorides 96 ( $\beta$-anomer only in $49 \%$ yield), demonstrating that oxidation of sulfide to sulfoxide is unnecessary step in the conversion of thioethers to $\alpha$-fluoro thioethers. On ${ }^{1} \mathrm{H}$ NMR spectrum the thioribosyl fluorides 96 showed a geminal coupling constant between F and H1 $(J=54.0 \mathrm{~Hz}) .{ }^{19} \mathrm{~F}$ NMR spectrum of 96 ( $\beta$-anomer) showed a ddd at $\delta-140.85(J=2.3,9.5,54.0 \mathrm{~Hz})$ whereas ${ }^{19} \mathrm{~F}$ NMR spectrum of 96 ( $\alpha$-anomer) showed a dd at $\delta-157.24(J=15.2,56.7 \mathrm{~Hz})$.

Since $\alpha$-fluoro thioethers are at the carbonyl oxidation level, these thioacetals were found to be sensitive to acidic conditions. ${ }^{142}$ I found out that under slightly acidic conditions, such as silica gel, a spontaneous hydrolysis of $\alpha$-fluoro thioethers 96 occurred to yield thiohemiacetals $\mathbf{9 9}$, as was proven by the loss of the fluoride signal in the ${ }^{19} \mathrm{~F}$ NMR. Since on the other hand $\alpha$-fluoro thioethers are relatively stable to basic 
conditions, in parallel with acetals, I discovered that treatment of 96 ( $\beta$-anomer) with methanolic ammonia effected deacetylation providing 97 as a single $\beta$-anomer. The fluoride $\mathbf{9 7}$ was then mesylated at primary hydroxyl to give reasonable stable $\mathbf{9 8}$. I was fortunate to find that coupling of $\mathbf{9 8}$ with protected Hcy (scheme 29) indeed afforded relatively stable 4-[thia]-SRH fluoride $\mathbf{1 0 0}$. Since the presence of moisture and slightly acidic conditions cause hydrolysis of thioribosyl fluoride to thiohemiacetals, attempted purification of the crude $\mathbf{1 0 0}$ on silica gel column yielded separable mixture of $\mathbf{1 0 0}(25 \%$ yield) and protected 4-[thia]-SRH derivative $\mathbf{1 0 1}$ as a single $\beta$ anomer (27\% yield). The structure of the 4-[thia]-SRH fluoride $\mathbf{1 0 0}$ was established by spectroscopic techniques. HRMS (AP-ESI) proved the molecular formula of $\mathrm{C}_{21} \mathrm{H}_{36} \mathrm{FNNaO}_{6} \mathrm{~S}_{2}[\mathrm{M}+\mathrm{Na}]^{+}(\mathrm{m} / \mathrm{z}$ 504.1847). Treatment of $\mathbf{1 0 0}$ with aqueous TFA effected hydrolysis of fluoride as well as removal of the $N$-Boc, acetonide, and $t$-butyl ester protection groups in a single step to give 4-[thia]-SRH derivative 39 in $91 \%$ yield as a mixture of anomers whose $\alpha: \beta$ anomeric ratio changed when stored in $\mathrm{D}_{2} \mathrm{O}$ from 1:1 $\rightarrow$ 1:4. Also acid catalyzed deprotection of $\mathbf{1 0 1}$ also led to the formation of 39. The structure of the 4-[thia]-SRH 39 was established by spectroscopic techniques. HRMS (AP-ESI) proved the molecular formula of $\mathrm{C}_{9} \mathrm{H}_{16} \mathrm{NO}_{5} \mathrm{~S}_{2}[\mathrm{M}-\mathrm{H}]^{-}(\mathrm{m} / z$ 282.0484). 


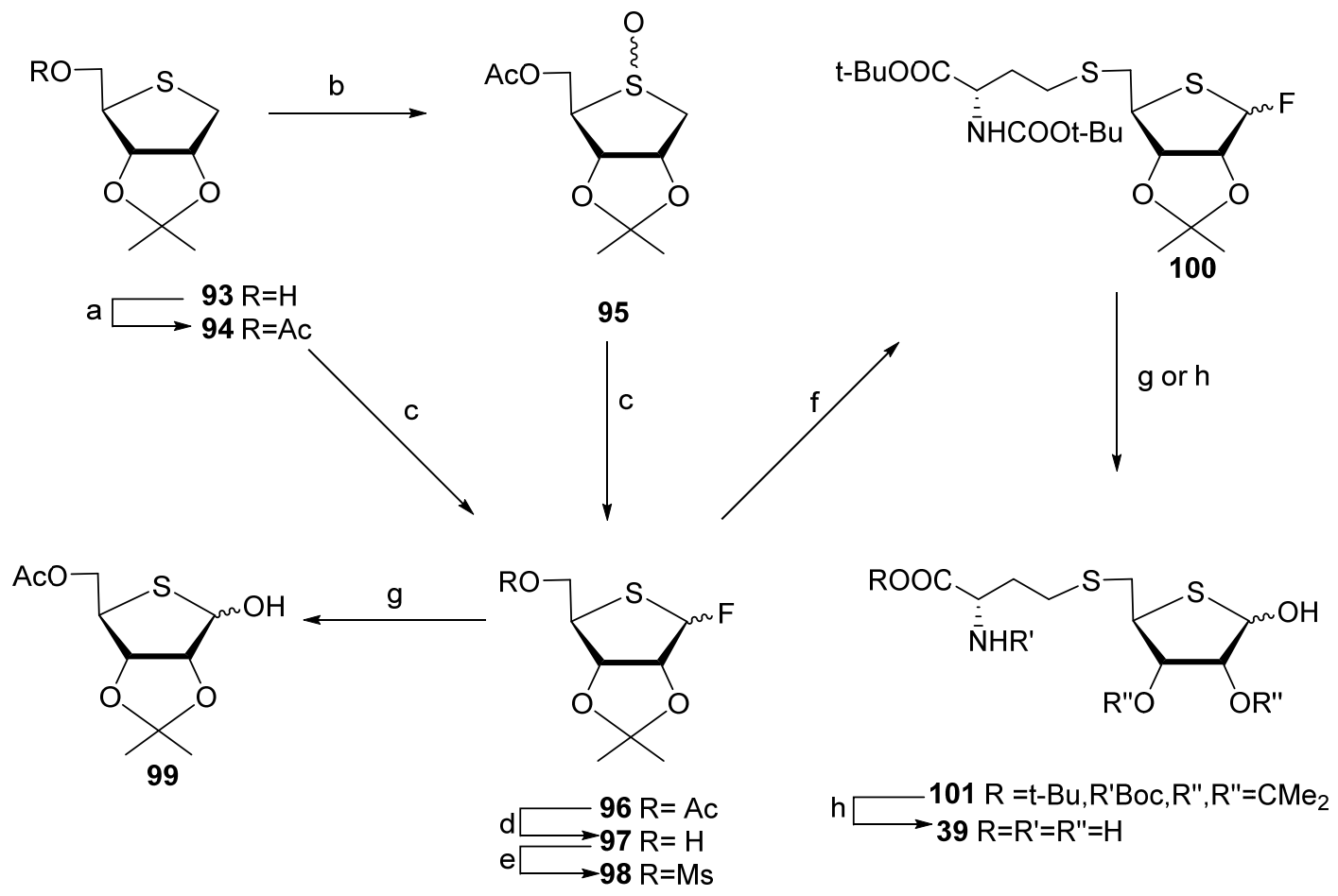

Reagents and conditions (a) Ac 2 O/DMAP; (b) MCPBA $/ \mathrm{CH}_{2} \mathrm{Cl}_{2} /-78^{\circ} \mathrm{C}$; (c) DAST/SbCl $3 / \mathrm{CH} 2 \mathrm{Cl} / 2 / 55^{\circ} \mathrm{C}$; (d) $\mathrm{NH} 3 / \mathrm{MeOH} ;(e) \mathrm{MsCl} / \mathrm{Et} 3 \mathrm{~N} / \mathrm{CH} 2 \mathrm{Cl}$; $(f) \mathrm{BocNHCH}(\mathrm{CHCHSH}) \mathrm{CO} 2 t-\mathrm{Bu} / \mathrm{LDA} / \mathrm{DMF} ;(g) \mathrm{H} 2 \mathrm{O} / \mathrm{H}+;(h) \mathrm{TFA} / \mathrm{H} 2 \mathrm{O}(9: 1)$.

\section{Scheme 31. Synthesis of [4-thia]-SRH analogue.}




\subsection{Biological activities}

\subsubsection{Inhibition of LuxS enzyme}

Interaction of the 4-C-alkyl/aryl-SRH lactose 90 and hemiacetals 92 will be studied in the collaboration with Professor Pei in Ohio State University and the results will be published elsewhere.

\subsubsection{Screening against $r h l$ and las in P. aeruginosa QS}

AI-2, known as the universal signaling molecule in bacteria ${ }^{144}$ with a known X-ray crystallographic $^{1}$ structure in complex with LuxP, has been targeted by different researchers. Meijler and coworkers. ${ }^{109}$ studied a panel of DPD analogues with 1 carbon increment in the alkyl chain at C2 (Figure 28). The extension in the alkyl group unit was thought to alter ligand induced conformational changes without changing the receptorligand affinities. Results showed that the presence of DPD, the synthesized DPD analogues acted as agonists, increasing luminescence in the $V$. Harveyi. Two theories were drawn from these findings: either (i) the analogues are allosterically interacting with the AI-2 receptor LuxP but only when DPD is present or (ii) they bind to an alternative site resulting in increased gene expression and DPD increased DPD induction. In order to further examine the preceding results, Ganin and coworkers focused on P. aeruginosa as a bacterium of choice to test their compounds since it is a bacterium that responds to AI- 2 but does not synthesize DPD by itself. Results showed that significant inhibition of luminescence occurred with butyl and pentyl-DPD with a maximum of $40 \%$ inhibition at $200 \mu \mathrm{M}$ for both. 


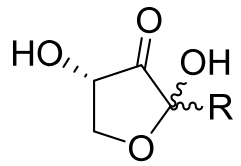

$\mathrm{R}=$ methyl, ethyl, propyl, butyl, pentyl, hexyl, heptyl

\section{Figure 28. Alkyl-DPD analogues. ${ }^{109}$}

To search for the effects of non-native AHL scaffold on QS, I have also tested the 4$C$-alkyl/aryl-SRH and 4-[thia]-SRH analogues against the $P$. aeruginosa QS. The different analogues were designed in a way to resemble SRH known to regulate QS through the LuxS-mediated biosynthesis of AI-2. In 4-[thia]-SRH analogues (39, Figure $29)$, the oxygen in the ribose unit is replaced by a sulfur atom or the sulfoxide moeity.

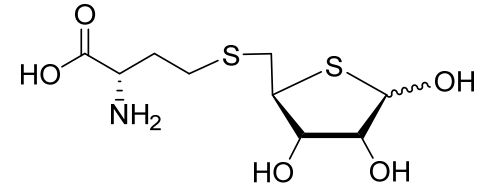

39

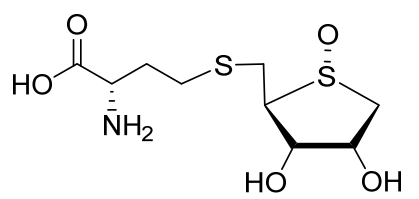

$(R) 103 a$

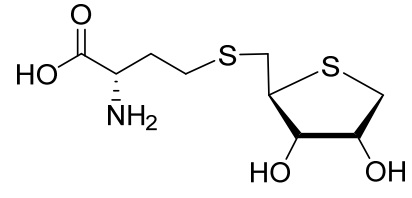

102

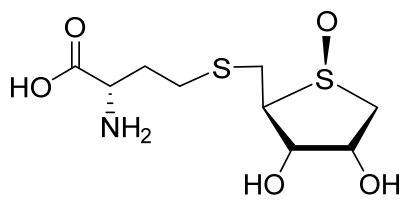

(S) $103 b$

$\mathrm{H}$

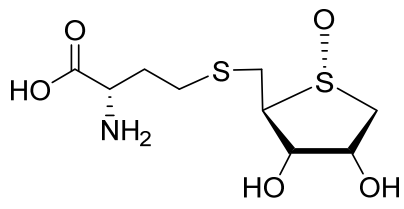

$(S / R) 103 c$

Figure 29. Thia-S-ribosyl-L-homocysteine analogues screened for their anti-QS activity and bacterial growth.

It is noteworthy to add that very recently a team of Dr Bassler and Dr Semmelhack reported novel thio-homoserine analogues: meta-chloro-thiolactone (mCTL) 104a and meta-bromo-thiolactone (mBTL) 104b (Figure 29) which were able to act as inhibitors of Pseudomonas aeruginosa QS and prevent biofilm formation and production of virulence 
factor. ${ }^{145}$ These compounds have similar structure to the lactams prepared by Malladi or the thiolactone analogues synthesized in this dissertation. The main difference is that the compounds synthesized by Malladi ${ }^{126}$ and in this dissertation, have a bulky Hcy fragment for 5-S-alkyl unit at $\mathrm{C} 4$ of the sugar ring while Bassler's new thiolactone analogues has the modified acetylated amino-fragment attached to $\mathrm{C} 2$.

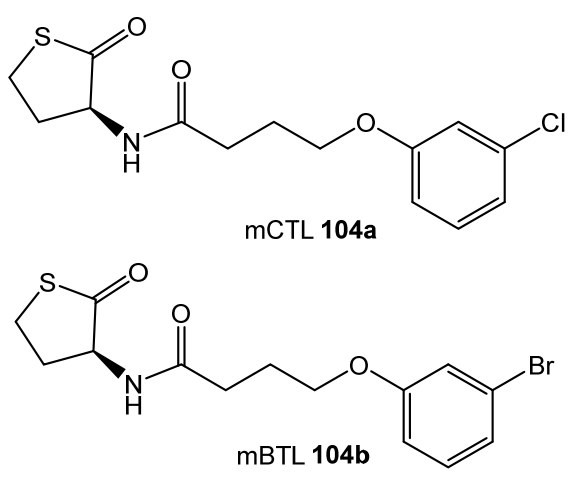

\section{Figure 30. Structure of meta-chloro/or bromo-thiolactone}

To determine the effect of the 4-[thia]-SRH analogues on the P. aeruginosa las and $r h l$ AHL-mediated pathways, las and $r h l$ - dependent $\beta$-galactosidase were expressed with their respective receptor proteins by Dr Kalai Mathee's research group at FIU. ${ }^{146}$ With the collaboration with Dr Mathee's laboratory, 4-[thia]-SRH compounds were tested against las and $r h l$, the $\mathrm{AHL}$ treated controls (3-oxo- $\mathrm{C}_{12}-\mathrm{AHL}$ in case of las and $\mathrm{C}_{4}-\mathrm{AHL}$ in case $r h l$ ) were in absence of inhibitors as $100 \%$ active (no activity was observed when AHL was absent).

\section{Screening against rhl signaling}

I found that 4-[thia]-SRH (39) did not show any effect on $r h l$ gene function $(110 \% r h l$ activity at $200 \mu \mathrm{g} / \mathrm{mL}$ ). The same lack of inhibitory effect was observed for the 1-deoxy[thia]-SRH analogue (102). From a pair of diasterioselectively pure sulfoxide, it was found that isomer $(S)$ at the sulfur atom in $\mathbf{1 0 3 b}$ has more inhibitory potential than the 
isomer $(R)$. At $100 \mu \mathrm{g} / \mathrm{mL}$ the $r h l$ activity was $85 \%$ compared to $125 \%$ for $103 \mathrm{a}$. The racemic mixture showed a median effect of $110 \%$ activity for $100 \mu \mathrm{g} / \mathrm{mL}$ of $\mathbf{1 0 3 c}$ concentration.

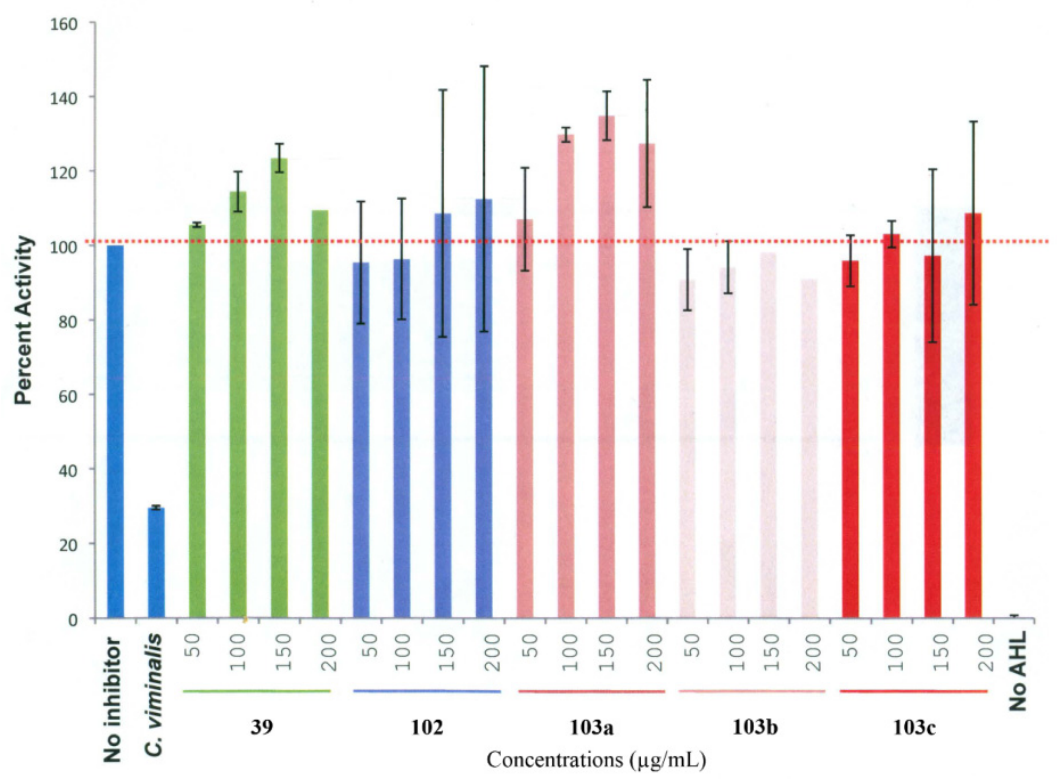

Figure 31. Effect of 4-thio-SRH analogues on $r h l$ expression in $P_{\text {.lasI-lac } Z \text { expression }}$ in E.coli (p- value < 0.05).

\section{Screening against las signaling}

As for their effect on las gene, all the preceding 4-thiofuranosides showed in general a significant concentration dependent inhibitory effect. The most potent among others was sulfoxide 103b that decreased the activity of las to $40 \%$ at $200 \mu \mathrm{g} / \mathrm{mL}$ concentration. Similar result was observed for the racemic mixture 103c which exhibited $35 \%$ las activity for $200 \mu \mathrm{g} / \mathrm{mL}$ concentration. The thioethers 39 and 102 had comparable inhibitory activity ( $55 \%$ las activity at $200 \mu \mathrm{g} / \mathrm{mL}$ concentration). 


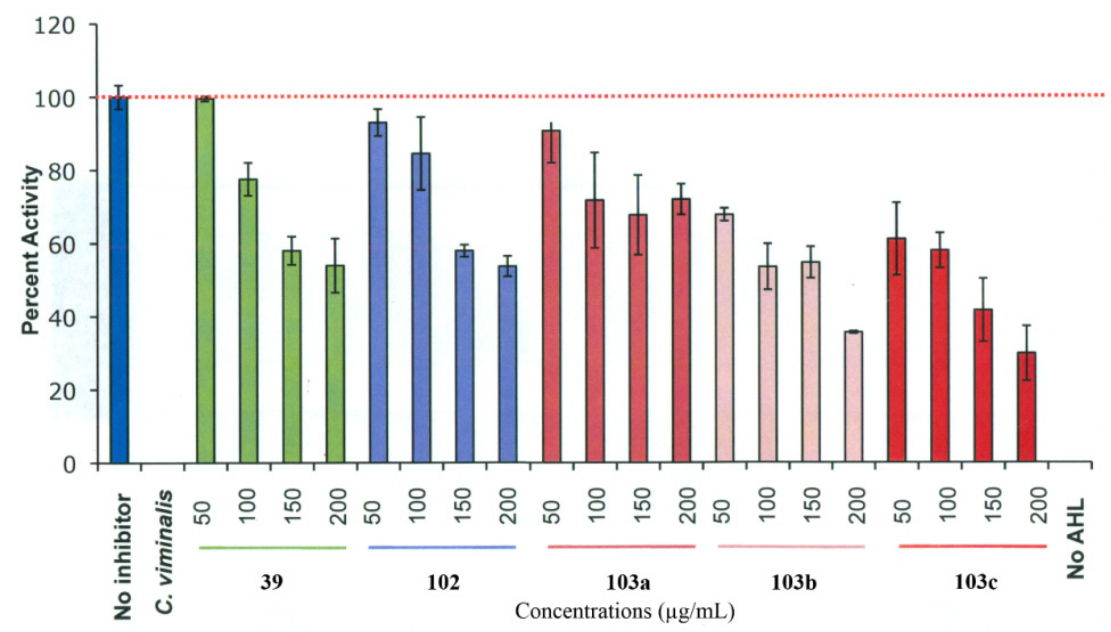

Figure 32. Effect of 4-thio-SRH analogues on las expression in $P_{\text {rhlaI-lac } Z \text { expression }}$ in E.coli (p- value < 0.05).

With the collaboration with Dr Makemson, the 4-[thia]-SRH analogues were also tested for their effect on QS mediated luminescence of wild-type $V$. harveyi. It was found that none of the tested compounds had any effect on bioluminescence. Most of the compounds had slight inhibition of the QS but not on total growth of the bacteria. In fact, $103 \mathrm{~b}$ and $103 \mathrm{c}$ had a slight stimulatory effect.

\begin{tabular}{|c|c|c|c|c|c|}
\hline & \multicolumn{2}{|c|}{ P. aeruginosa } & \multicolumn{3}{|c|}{$V$. harveyi } \\
\hline Compound & $\begin{array}{l}\text { Anti-QS } \\
\text { activity } \\
\text { against LasR }\end{array}$ & $\begin{array}{l}\text { Anti-QS } \\
\text { activity } \\
\text { against Rhl }\end{array}$ & Bioluminescence & QS & Growth \\
\hline 39 & inhibition & no effect & no effect & $\begin{array}{l}\text { slight } \\
\text { inhibition }\end{array}$ & no effect \\
\hline 102 & inhibition & no effect & no effect & $\begin{array}{l}\text { less than } \\
50 \% \\
\text { inhibition }\end{array}$ & no effect \\
\hline $103 a$ & $\begin{array}{l}\text { slight } \\
\text { inhibition }\end{array}$ & no effect & - & - & - \\
\hline $103 b$ & inhibition & no effect & no effect & $\begin{array}{l}\text { slight } \\
\text { inhibition }\end{array}$ & $\begin{array}{l}\text { slight } \\
\text { stimulatory }\end{array}$ \\
\hline $103 c$ & inhibition & no effect & no effect & $\begin{array}{l}\text { slight } \\
\text { inhibition }\end{array}$ & $\begin{array}{l}\text { slight } \\
\text { stimulatory }\end{array}$ \\
\hline
\end{tabular}

Table 5. Anti-QS activity and bacterial growth of 4-[thia]-SRH derivatives. 


\section{EXPERIMENTAL SECTION}

\subsection{General Procedures}

The ${ }^{1} \mathrm{H}(400 \mathrm{MHz}),{ }^{13} \mathrm{C}(100 \mathrm{MHz})$, or ${ }^{19} \mathrm{~F}(376 \mathrm{MHz})$ NMR spectra were recorded at ambient temperature in solutions of $\mathrm{CDCl}_{3}$ or $\mathrm{MeOH}-d_{4}$ or $\mathrm{D}_{2} \mathrm{O}$, as noted. Mass spectra (MS) were obtained with atmospheric pressure chemical ionization (APCI) or ESI technique and HRMS in AP-ESI or TOF-ESI mode. The reactions were followed by TLC with Merck Kieselgel $60-\mathrm{F}_{254}$ sheets and products were detected with a $254 \mathrm{~nm}$ light or with Hanessian's stain. Column chromatography was performed using Merck Kieselgel 60 (230-400 mesh). The purity of the newly synthesized compounds was determined to be $\geq 95 \%$ by elemental analysis $(C, H, N)$ and/or HPLC on X-terra ${ }^{\circledR}$ RPC18 with gradient program using $\mathrm{CH}_{3} \mathrm{CN} / \mathrm{H}_{2} \mathrm{O}$ as mobile phase. Reagent grade chemicals were used and solvents were dried by reflux distillation over $\mathrm{CaH}_{2}$ under nitrogen gas, unless otherwise specified, and reactions carried out under Ar atmosphere.

The compounds synthesized in my dissertation are considered, where possible, as sugar derivatives or SRH analogs thus the numbering of carbons followed carbohydrate nomenclature with anomeric carbon (or the precursor to anomeric carbon) designated as C1 (Figure 33). 

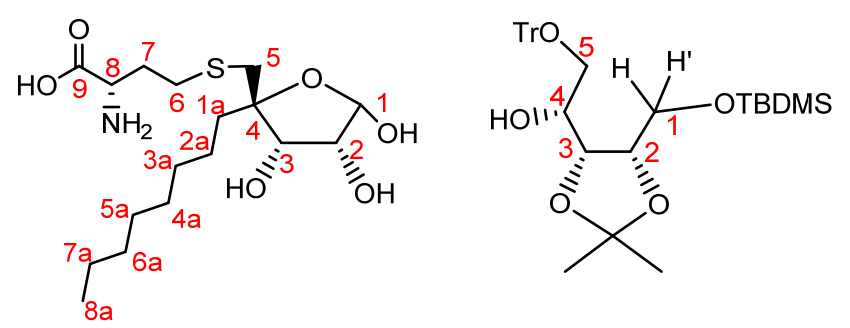

Figure 33. Numbering of the carbons in $S$-ribosylhomocysteine analogues and the corresponding sugar precursors used for the nomenclature of compounds and description of their NMR spectra.

The following General Procedures have been used to describe synthesis of targeted compounds:

Procedure A: Regioselective mesylation of the primary 5-hydroxyl group

Procedure B: Step a: Preparation of the protected homocysteine; Step b: Coupling of the homocysteine with the sugar precursor in the presence of $\mathrm{K}_{2} \mathrm{CO}_{3}$

Procedure C: Addition of the Grignard reagents to the ribitol-4-ulose

Procedure D: Deprotection of TBDMS group with TBAF

Procedure E: Oxidation of the primary hydroxyl with NMO/TPAP and ring closure to the lactones,

Procedure F: Removal of the 5-trityl protection group

Procedure G: Coupling of the homocysteine with the sugar precursors in the presence of LDA

Procedure H: Removal of the Boc, $t$ - $\mathrm{BuO}$ ester and isopropylidene protection groups with TFA and TFA/ $\mathrm{H}_{2} \mathrm{O}$

Procedure I: Reduction of the lactones to hemiacetals with $\mathrm{LiEt}_{3} \mathrm{BH}$ 


\subsection{Synthesis of the inhibitors and their spectroscopic characteristization}

2-Deoxy-D-ribonolactone (41). The 2-deoxyribose 40 (1.03 g, $7.45 \mathrm{mmol}$ ) was added to a solution of $\mathrm{Br}_{2}(2 \mathrm{~mL})$ in water $(6 \mathrm{~mL})$. The mixture was kept stirring at ambient temperature for 5 days and then silver carbonate was added to neutralize the mixture to $\mathrm{pH}=7$. The mixture was filtered and the filtrate was concentrated under reduced pressure to yield to yellow oil. The volatiles were evaporated and the sample was dried under vacuum to give $41^{130}(1.02 \mathrm{~g}, 90 \%):{ }^{1} \mathrm{H}$ NMR $\left(\mathrm{CDCl}_{3}\right) \delta 2.59(\mathrm{dd}, J=3.0$, $18.6 \mathrm{~Hz}, 1 \mathrm{H}, \mathrm{H} 2$ '), 3.05 (dd, $J=3.0,18.6 \mathrm{~Hz}, 1 \mathrm{H}, \mathrm{H} 2), 3.81(\mathrm{dd}, J=4.5,12.9 \mathrm{~Hz}, 1 \mathrm{H}$, H5'), 3.92 (dd, $J=3.1,12.9 \mathrm{~Hz}, 1 \mathrm{H}, \mathrm{H} 5), 4.50-4.60$ (m, 2H , H3, H4).

2-Deoxy-3,5-di-O-(tert-butyldimethylsilyl)-D-ribonolactone (42). Imidazole (2.5 g, $37.3 \mathrm{mmol})$ and TBDMSCl (4.5 g, $29.8 \mathrm{mmol})$ were added to compound 41 (1.0 g, 7.57 mmol) dissolved in anhydrous DMF $(20 \mathrm{~mL})$. The mixture was stirred at ambient temperature for 1 day and quenched by the addition of water. The water layer was extracted with EtOAc $(3 \times 10 \mathrm{~mL})$ and the organic layers were combined, washed with brine and dried with anhydrous $\mathrm{Mg}_{2} \mathrm{SO}_{4}$ and evaporated. The remaining residue was column chromatographed (90\% hexane/EtOAc) to give $\mathbf{4 2}^{130}(750 \mathrm{mg}, 80 \%):{ }^{1} \mathrm{H}$ NMR $\left(\mathrm{CDCl}_{3}\right) \delta$ 0.08-0.10 (m, 12H), 0.80-0.91 (s, 18H), $2.35(\mathrm{dd}, J=2.6,17.6 \mathrm{~Hz}, 1 \mathrm{H}, \mathrm{H} 2)$, $2.80\left(\mathrm{dd}, J=6.7,17.6 \mathrm{~Hz}, 1 \mathrm{H}, \mathrm{H} 2^{\prime}\right), 3.74(\mathrm{dd}, J=2.5,11.4 \mathrm{~Hz}, 1 \mathrm{H}, \mathrm{H} 5), 3.78$ (dd, $J=$ 3.2, 11.5 Hz, 1H, H5'), 4.30-4.32 (m, 1H, H3), 4.46-4.81 (m, 1H, H4).

2-Bromo-2-deoxy-3,5-di- $O$-(tert-butyldimethysilyl)-D-ribonolactone (43a) and 2bromo-2-deoxy-3,5-di-O-(tert-butyldimethysilyl)-D-arabinonolactone

(43b). Triethylamine $(0.42 \mathrm{~mL}, 303 \mathrm{mg}, 3.0 \mathrm{mmol})$ and TMSOTf $(333 \mathrm{mg}, 1.5 \mathrm{mmol})$ were added to a stirred solution of $42(180 \mathrm{mg}, 0.50 \mathrm{mmol})$ in $\mathrm{CH}_{2} \mathrm{Cl}_{2}(6 \mathrm{~mL})$ at $0{ }^{\circ} \mathrm{C}$ for 30 
min. A solution NBS (134 mg, $0.75 \mathrm{mmol})$ in $1.5 \mathrm{~mL}$ of $\mathrm{CH}_{2} \mathrm{Cl}_{2}$ was added and the mixture was kept stirring for $1 \mathrm{~h}$ at $0{ }^{0} \mathrm{C}$. The volatiles were evaporated and the residue was washed with saturated $\mathrm{NaHCO}_{3}$ and extracted with $\mathrm{CH}_{2} \mathrm{Cl}_{2}$. The combined organic layer was washed with brine, dried with anhydrous $\mathrm{Mg}_{2} \mathrm{SO}_{4}$ and silica gel column chromatographed $(85 \%$ hexane/EtOAc) to give a mixture of ribo:arabino epimers 43a/43b ${ }^{130}(1: 2 ; 167 \mathrm{mg}, 76 \%)$. Ribo-epimer had: ${ }^{1} \mathrm{H}$ NMR $\left(\mathrm{CDCl}_{3}\right) \delta$ 0.08-0.10 (m, $12 \mathrm{H}), 0.80-0.91(\mathrm{~s}, 18 \mathrm{H}), 3.75(\mathrm{dd}, J=2.0,6.4 \mathrm{~Hz}, 1 \mathrm{H}, \mathrm{H} 5), 3.95(\mathrm{dd}, J=2.3,4.9 \mathrm{~Hz}$, 1H, H5'), 4.17-4.22 (m, 1H, H4), 4.38-4.40 (m, 1H, H3), 4.65 (t, $J=6.0,12.7 \mathrm{~Hz}, 1 \mathrm{H}$, H2). Arabino-epimer had: ${ }^{1} \mathrm{H}$ NMR $\left(\mathrm{CDCl}_{3}\right)$ 0.08-0.10 (m, 12H), 0.80-0.91 (m, 18H), 3.77 (dd, $J=3.0,6.2 \mathrm{~Hz}, 1 \mathrm{H}, \mathrm{H} 5), 3.90\left(\mathrm{dd}, J=2.2,4.8 \mathrm{~Hz}, 1 \mathrm{H}, \mathrm{H} 5{ }^{\prime}\right), 4.27-4.32(\mathrm{~m}, 1 \mathrm{H}$, H4), $4.36(\mathrm{~d}, 1 \mathrm{H}, J=4.9 \mathrm{~Hz}, 1 \mathrm{H}, \mathrm{H} 3), 4.46(\mathrm{~d}, J=5.6 \mathrm{~Hz}, 1 \mathrm{H}, \mathrm{H} 2) . \mathrm{MS}\left(\mathrm{ESI}^{+}\right) m / z 456$ $\left(98, \mathrm{M}+\mathrm{NH}_{4}{ }^{+},\left[{ }^{79} \mathrm{Br}\right]\right), 458\left(100, \mathrm{M}+\mathrm{NH}_{4}{ }^{+},\left[{ }^{81} \mathrm{Br}\right]\right)$.

2-Bromo-2-deoxy-3-O-tert-butyldimethysilyl-arabinonolactone (44). A solution of 43b (25 mg, $0.05 \mathrm{mmol})$ in $\mathrm{TFA} / \mathrm{H}_{2} \mathrm{O}(2 \mathrm{~mL}, 9: 1)$ was stirred for $1 \mathrm{~h}$ at $0{ }^{\circ} \mathrm{C}$. Volatiles were evaporated and the residue was co-evaporated with toluene $(0.1 \mathrm{~mL})$. Purification of the residue on flash column chromatography column (hexane/EtOAc, 85:15) gave 44 (19 mg, 90\%): ${ }^{1} \mathrm{H}$ NMR $\left(\mathrm{CDCl}_{3}\right) \delta 0.17 \& 0.20(2 \times \mathrm{s}, 2 \times 3 \mathrm{H}), 0.90(\mathrm{~s}, 9 \mathrm{H}), 3.76(\mathrm{~d}, J=12.8$ Hz, 1H, H5), 4.08 (d, $J=13.0$ Hz, H5'), 4.20-4.31 (m, 1H, H4), 4.44 (t, $J=5.8,11.5 \mathrm{~Hz}$, 1H, H3), $4.48(\mathrm{~d}, J=5.6 \mathrm{~Hz}, 1 \mathrm{H}, \mathrm{H} 2) ;{ }^{13} \mathrm{C} \mathrm{NMR}\left(\mathrm{CDCl}_{3}\right) \delta-5.78,-6.06\left(\mathrm{Si}-\mathrm{Me}_{2}\right), 22.16$ (C-Me $\left.e_{3}\right), 25.71\left(C-\mathrm{Me}_{3}\right), 44.85$ (C2), 58.41 (C5), 67.26 (C3), 83.23 (C4), 169.55 (C1). $\operatorname{MS}\left(\mathrm{ESI}^{+}\right) \mathrm{m} / z 342\left(98, \mathrm{M}+\mathrm{NH}_{4}{ }^{+},\left[{ }^{79} \mathrm{Br}\right]\right), 344\left(100, \mathrm{M}+\mathrm{NH}_{4}{ }^{+},\left[{ }^{81} \mathrm{Br}\right]\right)$.

2-Bromo-2-deoxy-3-O-tert-butyldimethysilyl-5-O-mesyl-arabinonolactone (45).

Procedure A: TEA (42 $\mu \mathrm{L}, 30 \mathrm{mg}, 0.29 \mathrm{mmol})$ and $\mathrm{MsCl}(9.3 \mu \mathrm{L}, 13 \mathrm{mg}, 0.11 \mathrm{mmol})$ 
were added to a stirred solution of $44(34 \mathrm{mg}, 0.104 \mathrm{mmol})$ in dry $\mathrm{CH}_{2} \mathrm{Cl}_{2}(1.75 \mathrm{~mL})$ at 0 ${ }^{\circ} \mathrm{C}$ (ice-bath) under $\mathrm{N}_{2}$ atmosphere. After $5 \mathrm{~min}$, the ice bath was removed and the reaction mixture was partitioned between $\mathrm{CH}_{2} \mathrm{Cl}_{2}$ and diluted $\mathrm{HCl}$. The separted organic layer was then washed with aqueous solution of $\mathrm{NaHCO}_{3}$ and brine and was then dried over anhydrous $\mathrm{MgSO}_{4}$. Column chromatography (85\% hexane/EtOAc) gave 45 (26 mg, 60\%): ${ }^{1} \mathrm{H} \mathrm{NMR}\left(\mathrm{CDCl}_{3}\right) \delta 0.17 \& 0.20(2 \times \mathrm{s}, 2 \times 3 \mathrm{H}), 0.90(\mathrm{~s}, 9 \mathrm{H}), 3.06(\mathrm{~s}, 3 \mathrm{H}), 4.28(\mathrm{t}$, $J=5.8,12.7 \mathrm{~Hz}, 1 \mathrm{H}, \mathrm{H} 3), 4.36(\mathrm{~d}, J=5.9 \mathrm{~Hz}, \mathrm{H} 2), 4.40$ (dd, $J=3.0,12.0 \mathrm{~Hz}, 1 \mathrm{H}, \mathrm{H} 5)$, 4.47-4.50 (m, 1H, H4), $4.56(\mathrm{dd}, J=2.2,12.1 \mathrm{~Hz}, 1 \mathrm{H}, \mathrm{H} 5 ')$; MS $\left(\mathrm{ESI}^{+}\right) \mathrm{m} / z 451.9$ (98, $\left.\mathrm{M}+\mathrm{NH}_{4}{ }^{+}+\mathrm{CH}_{3} \mathrm{OH},\left[{ }^{79} \mathrm{Br}\right]\right), 453.9\left(100, \mathrm{M}+\mathrm{NH}_{4}{ }^{+}+\mathrm{CH}_{3} \mathrm{OH},\left[{ }^{81} \mathrm{Br}\right]\right)$.

\section{2-Deoxy-3-O-tert-butyldimethysilyl-2-[(tert-butoxycarbonyl)-L-homocysteine}

tert-butyl ester]arabinonolactone (50). Procedure B. Step a. $\mathrm{H}_{2} \mathrm{O}(0.45 \mathrm{~mL})$ and tris(2carboxyethyl)phosphine hydrochloride $(70 \mathrm{mg}, 0.24 \mathrm{mmol})$, were added to a stirred solution of $N^{\prime}, N^{\prime}$-di(tert-butoxycarbonyl)-L-homocystine di(tert-butyl) ester ${ }^{67} 48$ (100 mg, $0.17 \mathrm{mmol})$ in anhydrous DMF $(5 \mathrm{~mL})$ at room temperature under Ar atmosphere. After 24 hours, the reaction mixture showed on TLC ( $80 \%$ hexane/EtOAc) the conversion of the disulfide moiety into a thiol 49. The reaction mixture was partitioned between $\mathrm{NAHCO}_{3} / \mathrm{H}_{2} \mathrm{O}$ and ethyl acetate. The organic layer was separated and was washed with brine, dried $\left(\mathrm{MgSO}_{4}\right)$ and was evaporated to give $49^{67}$ (98 mg, 99\%) as a colorless oil of sufficient purity to be used in the next step: ${ }^{1} \mathrm{H}$ NMR $\left(\mathrm{CDCl}_{3}\right) \delta 1.40(\mathrm{~s}, 10 \mathrm{H}), 1.51(\mathrm{~s}$, $10 \mathrm{H}), 1.9(\mathrm{~m}, 1 \mathrm{H}), 2.09-2.12(\mathrm{~m}, 1 \mathrm{H}), 2.6(\mathrm{~m}, 1 \mathrm{H}), 4.30(\mathrm{~d}, J=5.2 \mathrm{~Hz}, 1 \mathrm{H}), 5.10(\mathrm{~d}, J=$ 7.6 Hz, 1H, NH). Step $b . \mathrm{K}_{2} \mathrm{CO}_{3}(40 \mathrm{mg}, 0.29 \mathrm{mmol})$ was added to a stirred solution of $\mathbf{4 5}$ (20 mg, $0.05 \mathrm{mmol})$ and $49(14.2 \mathrm{mg}, 0.04 \mathrm{mmol})$ in dry acetone $(5 \mathrm{~mL})$. The heterogeneous mixture was refluxed for $1 \mathrm{~h}$ under argon atmosphere. Volatiles were 
evaporated and the residue was partitioned between EtOAc $(10 \mathrm{~mL})$ and $\mathrm{NaHCO}_{3}(10$ $\mathrm{mL}$ ). The combined organic layer was evaporated and the residue was column chromatographed $\left(80 \%\right.$ hexane/EtOAc) to give $\mathbf{5 0}(5 \mathrm{mg}, 20 \%):{ }^{1} \mathrm{H}$ NMR $\left(\mathrm{CDCl}_{3}\right) \delta$ 0.08-0.10 (m, 6H), 0.80-0.91 (s, 9H), 1.39 (2 x s, 18 H), 1.90 - 2.11 (m, 2H, H7, H7'), $2.25-2.40$ (m, 2H, H6, H6'), 3.01 (s, 3H, Ms), 4.15- 4.25 (m, 1H, H8), 4.70 (d, $J=3.2$ $\mathrm{Hz}, 1 \mathrm{H}, \mathrm{H} 2), 5.00(\mathrm{~d}, J=2.5, \mathrm{NH}), 5.30(" \mathrm{t} ", 1 \mathrm{H}, \mathrm{H} 3) ;{ }^{13} \mathrm{C} \mathrm{NMR}\left(\mathrm{CDCl}_{3}\right) \delta 8.62\left(\mathrm{SiMe}_{2}\right)$, $14.16\left(\mathrm{NCMe}_{3}\right), 21.00\left(\mathrm{OMe}_{3}\right), 22.65$ (C7), 23.09 (C6), 29.57 ( $\left.\mathrm{SiCMe}_{3}\right), 32.12\left(\mathrm{SiCMe}_{3}\right)$, 37.00 (Ms), 46.03 (CH-NBoc), 46.76 (C2), 60.38 (C5), 66.69 (C3), 163.73(CO), 171.15 (CO), $180.0(\mathrm{CO})$.

5-O-Mesyl-3-O-tert-butyldimethylsilyl-2-S-propyl-2-thioribonolactone (50a). LDA ( $2 \mathrm{M} / \mathrm{THF}$ and heptanes, $20 \mu 1,0.04 \mathrm{mmol}$ ) was added slowly to a stirred solution of propylthiol $(3.8 \mathrm{mg}, 0.05 \mathrm{mmol})$ in anhydrous DMF $(2 \mathrm{ml})$ under Ar atmosphere at $0{ }^{\circ} \mathrm{C}$ (ice bath). After $30 \mathrm{~min}$, a solution of $45(10 \mathrm{mg}, 0.02 \mathrm{mmol})$ in DMF (2 mL) was added by a syringe and the mixture was continued to stirr for $1 \mathrm{~h}$ at $0{ }^{\circ} \mathrm{C}$ then at room temperature for 24 hours. The TLC showed the formation of new less polar product. The reaction was quenched with $\mathrm{NH}_{4} \mathrm{Cl}$ and the volatiles were evaporated under high vaccum. The residue was partitioned between EtOAc and $\mathrm{NaHCO}_{3}$, and the organic layer was washed with brine and dried with anhydrous $\mathrm{MgSO}_{4}$. The resulting oil was column chromatographed (7:3, hexane/EtOAc) to give 50a as a mixture of two isomers $(\alpha: \beta, 1: 1$; $6 \mathrm{mg}, 61 \%):{ }^{1} \mathrm{H}$ NMR $\left(\mathrm{CDCl}_{3}\right) \delta 0.08-0.10(\mathrm{~m}, 12 \mathrm{H}), 0.80-0.91(\mathrm{~s}, 18 \mathrm{H}), 1.10(\mathrm{t}, J=6.6$ $\mathrm{Hz}, 6 \mathrm{H}, 2$ x Me), 1.45-1.47 (m, 4H, 2 x 2H), 2.45-2.48 (m, 4H, 2 x CH $2 \mathrm{~S}), 3.06$ (s, 6H, 2 x Me), $3.20(\mathrm{~d}, J=5.5 \mathrm{~Hz}, 1 \mathrm{H}, \mathrm{H} 2), 3.45(\mathrm{~d}, J=6.4 \mathrm{~Hz}, 1 \mathrm{H}, \mathrm{H} 2), 4.05(\mathrm{t}, J=3.2 \mathrm{~Hz}, 1 \mathrm{H}$, H3), 4.17 (dd, $J=3.6,12.1 \mathrm{~Hz}, 1 \mathrm{H}, \mathrm{H} 5), 4.22-4.25$ (m, 1H, H4), 4.26-4.33 (m, 2H, H5 
and H5'), 4.34 (t, $\left.J=2.7 \mathrm{~Hz}, \mathrm{H} 5^{\prime}\right), 4.38$ (t, $\left.J=2.2 \mathrm{~Hz}, 1 \mathrm{H}, \mathrm{H} 4\right), 4.40$ (t, $J=6.8 \mathrm{~Hz}, 1 \mathrm{H}$, H3). ${ }^{13} \mathrm{C}$ NMR $-5.18 \&-4.25\left(\mathrm{Si}-(\mathrm{Me})_{2}\right), 14.15 \& 14.21(\mathrm{Me}), 17.84 \& 18.11\left(\mathrm{CH}_{2}\right)$, $21.09 \& 22.67\left(\mathrm{Si}-\mathrm{C}-(\mathrm{Me})_{3}\right), 25.60\left(\mathrm{Si}-\mathrm{C}-(\mathrm{Me})_{3}\right), 31.61 \& 33.71\left(\mathrm{CH}_{2}\right), 37.78 \& 37.89$ (S-Me), $48.81 \& 60.43$ (C2), $66.09 \& 66.38$ (C3), $69.61 \& 73.81$ (C5), $8.73 \& 82.25$ (C4), $171.47 \& 172.74(\mathrm{CO})$.

6-Deoxy-3-fluoro-1,2-O-isopropylidene- $\alpha$-D-glucofuranose (55). A solution of $54^{131,133}(0.02 \mathrm{~g}, 0.076 \mathrm{mmol})$ in dioxane $(0.24 \mathrm{~mL})$ and ethanol $(0.12 \mathrm{~mL})$ in the presence of $\mathrm{H}_{2} \mathrm{SO}_{4}(5 \mathrm{M}, 0.04 \mathrm{~mL})$ was stirred at room temperature for $4 \mathrm{~h}$. The reaction was then neutralized with $\mathrm{Na}_{2} \mathrm{CO}_{3}$ and extracted with $\mathrm{CH}_{2} \mathrm{Cl}_{2}$. The organic layer was washed with brine, dried and evaporated to give $\mathbf{5 5}^{131}$ (19 $\mathrm{mg}, 90 \%$ ) of sufficient purity to be directly used in the next step: ${ }^{1} \mathrm{H}$ NMR $\left(\mathrm{CDCl}_{3}\right) \delta 1.30(\mathrm{~s}, 3 \mathrm{H}), 1.50(\mathrm{~s}, 3 \mathrm{H}), 3.81$ (dd, $J=5.0,11.3 \mathrm{~Hz}, \mathrm{H6}$ ), 3.90 (dd, $J=3.2,11.4 \mathrm{~Hz}, \mathrm{H6}$ ), 3.95-4.01 (m, 1H, H5), 4.20 (ddd, $J=2.2,8.5,29.4 \mathrm{~Hz}, 1 \mathrm{H}, \mathrm{H} 4), 4.70$ (dd, $J=3.7,10.8 \mathrm{~Hz}, 1 \mathrm{H}, \mathrm{H} 2), 5.10$ (dd, $J=$ 2.2, $50.2 \mathrm{~Hz}, 1 \mathrm{H}, \mathrm{H} 3), 5.90(\mathrm{~d}, J=3.7 \mathrm{~Hz}, 1 \mathrm{H}, \mathrm{H} 2) ;{ }^{19} \mathrm{~F}$ NMR $\delta-208.11(\mathrm{ddd}, J=10.9$, 29.3, 50.0 Hz).

\section{6-O-Benzoyl-3-deoxy-3-fluoro-1,2-O-isopropylidene- $\alpha$-D-glucofuranose}

(56).

Benzoyl chloride $(0.1 \mathrm{~mL}, 130 \mathrm{mg}, 0.92 \mathrm{mmol})$ was added dropwise to a stirred solution of $55(200 \mathrm{mg}, 0.9 \mathrm{mmol})$ in dry pyridine $(2.5 \mathrm{~mL})$ and $\mathrm{CH}_{2} \mathrm{Cl}_{2}(0.9 \mathrm{~mL})$ at $-15^{\circ} \mathrm{C}$ under $\mathrm{N}_{2}$ atmosphere. After $3 \mathrm{~h}$, volatiles were removed and the residue was dissolved in $\mathrm{CHCl}_{3}$ $(2 \mathrm{~mL})$. The resulting solution was washed with saturated $\mathrm{NaHCO}_{3}$ aquous solution $(3 \mathrm{x}$ $1.5 \mathrm{~mL})$, water $(2 \times 1.5 \mathrm{~mL})$, dried $\left(\mathrm{Na}_{2} \mathrm{SO}_{4}\right)$ and evaporated to give $\mathbf{5 6}^{131}(61 \mathrm{mg}, 34 \%)$ as colorless solid: ${ }^{1} \mathrm{H}$ NMR $\left(\mathrm{CDCl}_{3}\right) \delta 1.30(\mathrm{~s}, 3 \mathrm{H}), 1.50(\mathrm{~s}, 3 \mathrm{H}), 4.10-4.15(\mathrm{~m}, 1 \mathrm{H}, \mathrm{H} 5)$, 
4.18-4.21 (m, 1H, H4), 4.40 (dd, $J=10.0,11.8 \mathrm{~Hz}, 1 \mathrm{H}, \mathrm{H} 6), 4.61-4.67$ (m, 2H, H2, H6'), $5.10(\mathrm{dd}, J=2.0,49.4,1 \mathrm{H}, \mathrm{H} 3), 6.01(\mathrm{~d}, J=3.7 \mathrm{~Hz}, 1 \mathrm{H}, \mathrm{H} 1), 7.41-7.92$ (m, 5H, Ar).

6-O-Benzoyl-3-deoxy-3-fluoro-D-glucofuranose (57). TFA/ $\mathrm{H}_{2} \mathrm{O}(9 / 1,1.5 \mathrm{~mL})$, was added to dry $56(31 \mathrm{mg}, 0.97 \mathrm{mmol})$ and left stirring for half hour at $0{ }^{\circ} \mathrm{C}$ (ice-bath) then left for an additional half hour at ambient temperature. The volatiles were co-evaporated with toluene then dried to give a mixture of $\alpha$ : $\beta$ isomers compound $\mathbf{5 7 a} / \mathbf{5 7 b} \mathbf{b}^{131}(1: 3 ; 26$ mg, 92\%): ${ }^{1} \mathrm{H}$ NMR $\left(\mathrm{CDCl}_{3}\right) \delta 3.70-3.80$ (m, 2H, H2, H6'), 4.10-4.17 (m, H5, 1H), 4.454.75 (m, 2H, H3, H6), 4.65 ("t", $J=9.1,18.0, \mathrm{H} 4,1 \mathrm{H}), 5.30$ (s, 0.5H, H1; $\beta$-isomer), 6.01 (d, $J=3.1 \mathrm{~Hz}, 0.5 \mathrm{H}, \mathrm{H1}$; $\alpha$-isomer), 7.41-7.92 (m, 5H, Ar). ${ }^{19} \mathrm{~F}$ NMR $\delta-195.65$ (dt, $J=$ 4.7, 54.7 Hz), $-200.60(\mathrm{dt}, J=11.8,53.6 \mathrm{~Hz})$.

6-O-Benzoyl-2-deoxy-2-fluoro-D-arabinofuranose (60). Step a. $\mathrm{NaIO}_{4}(23 \mathrm{mg}, 0.10$ mmol) was added to a stirred solution of $57^{131}(23 \mathrm{mg}, 0.08 \mathrm{mmol})$ in water $(3 \mathrm{~mL})$ at ambient temperature and left overnight. The mixture was then extracted with chloroform $(30 \mathrm{~mL})$, the organic layer was dried over anhydrous $\mathrm{MgSO}_{4}$. Step $b$. The crude material from Step a $(25 \mathrm{mg})$ was dissolved in $\mathrm{MeOH}(2 \mathrm{~mL})$ and $\mathrm{MeONa}(3 \mathrm{mg}, 0.05 \mathrm{mmol})$ was added. The resulting mixture was stirred at ambient temperature for $1 \mathrm{~h}$. The volatile were evaporated and the residue was column chromatographied (30\% hexane/EtOAc) gave a mixture of $\alpha: \beta$ isomers $60 \mathrm{a} / \mathbf{b}(1: 9 ; 20 \mathrm{mg}, 86 \%)$. The major anomer had: ${ }^{1} \mathrm{H}$ NMR $\left(\mathrm{CDCl}_{3}\right) \delta 4.25(\mathrm{~d}, J=9.2,1 \mathrm{H}, \mathrm{H} 4), 4.45\left(\mathrm{~m}, 2 \mathrm{H}, \mathrm{H} 6, \mathrm{H} 6{ }^{\prime}\right), 4.6(\mathrm{~s}, 1 \mathrm{H}), 5.01(\mathrm{~d}, J=49.8$, H2, 1H), 5.40 (dd, H3, $J=3.3,20.7 \mathrm{~Hz}, 1 \mathrm{H}), 5.65$ (d, $J=10.8 \mathrm{~Hz}, \mathrm{H} 1), 7.41-7.92$ (m, 5H, Ar). ${ }^{19} \mathrm{~F}$ NMR $\delta-190.58(\mathrm{ddd}, J=11.1,21.8,49.2 \mathrm{~Hz}, 0.9 \mathrm{~F})$ and $\delta-190.94$ (ddd, $J=$ 10.8, 19.6, 54.0 Hz, 0.1F). 
2,3-O-Isopropylidene-5-O-trityl-D-ribitol (71). $\mathrm{NaBH}_{4}(4.0 \mathrm{mg}, 0.10 \mathrm{mmol})$ was added to a stirred solution of $\mathbf{7 0}^{134,147}(30 \mathrm{mg}, 0.07 \mathrm{mmol})$ in $\mathrm{EtOH}(1 \mathrm{~mL})$ at $0{ }^{\circ} \mathrm{C}$ (icebath) under $\mathrm{N}_{2}$ atmosphere. After $1 \mathrm{~h}$, the reaction mixture was partitioned between $\mathrm{NaHCO}_{3} / \mathrm{H}_{2} \mathrm{O}$ and EtOAc $(15 \mathrm{~mL})$. The organic layer was dried over anhydrous $\mathrm{MgSO}_{4}$ and evaporated. The residue was column chromatographied ( $30 \%$ hexane/EtOAc) to give $7^{134}(25 \mathrm{mg}, 83 \%):{ }^{1} \mathrm{H} \mathrm{NMR}\left(\mathrm{CDCl}_{3}\right) \delta 0.08\left(\mathrm{~s}, 6 \mathrm{H}, 2 \times \mathrm{CH}_{3}\right), 2.96(\mathrm{~d}, J=3.6 \mathrm{~Hz}, 1 \mathrm{H})$, $3.08(\mathrm{dd}, J=5.0,8.4 \mathrm{~Hz}, 1 \mathrm{H}), 3.34(\mathrm{dd}, J=6.9,9.8 \mathrm{~Hz}, 1 \mathrm{H}), 3.50(\mathrm{dd}, J=2.9,9.8 \mathrm{~Hz}$, $1 \mathrm{H}), 3.75-7.81(\mathrm{~m}, 1 \mathrm{H}), 3.83-3.91(\mathrm{~m}, 2 \mathrm{H}), 4.10-4.75(\mathrm{~m}, 1 \mathrm{H}), 4.33-4.40(\mathrm{~m}, 1 \mathrm{H}), 7.25-$ $7.38(\mathrm{~m}, 15 \mathrm{H}, \mathrm{Ar})$.

\section{1-O-tert-Butyldimethysilyl-2,3-O-isopropylidene-5-O-trityl-D-ribitol}

TBSMSCl (139 mg, $0.92 \mathrm{mmol})$ and imidazole $(93.9 \mathrm{mg}, 1.38 \mathrm{mmol})$ were added to a solution of 71 (200 mg, $0.46 \mathrm{mmol})$ in DMF (4 mL) at room temperature and stirring was continued for $72 \mathrm{~h}$. The volatiles were evaporated and the residue was partitioned between saturated $\mathrm{NH}_{4} \mathrm{Cl} / \mathrm{H}_{2} \mathrm{O}$ and EtOAc. The separated organic layer was then washed with $\mathrm{NaHCO}_{3} / \mathrm{H}_{2} \mathrm{O}$, dried over $\mathrm{Mg}_{2} \mathrm{SO}_{4}$, evaporated and the resulting residue was column chromatographed (50\% hexane/EtOAc) to give $\mathbf{7 2}^{134}(180 \mathrm{mg}, 71 \%)$ as an amorphous white powder: ${ }^{1} \mathrm{H}$ NMR $\left(\mathrm{CDCl}_{3}\right) \delta 0.08$ (s, 6H, SiMe $), 0.81$ (s, 9H, Si-C-Me $), 1.20$ (s, 6H, $2 \times \mathrm{Me}$ ), 3.20 (dd, $J=5.3,9.7 \mathrm{~Hz}, 1 \mathrm{H}, \mathrm{H} 5), 3.25$ (dd, $\left.J=2.8,9.7 \mathrm{~Hz}, 1 \mathrm{H}, \mathrm{H} 5^{\prime}\right), 3.49$ (dd, $J=4.1,10.6 \mathrm{~Hz}, 1 \mathrm{H}, \mathrm{H1}), 3.68$ (dd, $J=8.7,10.5 \mathrm{~Hz}, 1 \mathrm{H}, \mathrm{H1}$ ), 3.79-3.81 (m, 1H, H4), 4.13-3.15 (m, 1H, H2), 4.22 (dd, $J=5.5,9.2 \mathrm{~Hz}, 1 \mathrm{H}, \mathrm{H} 3), 7.25-7.38$ (m, 15H, Ar).

\section{1-O-tert-Butyldimethysilyl-2,3-O-isopropylidene-5-O-trityl-D-ribitol-4-ulose (73).}

Dess-Martin reagent (15 wt $\%$ solution $/ \mathrm{CH}_{2} \mathrm{Cl}_{2} ; 3.0 \mathrm{~mL}, 492 \mathrm{mg}, 1.16 \mathrm{mmol}$ ) was added to a solution of $72(320 \mathrm{mg}, 0.58 \mathrm{mmol})$ in $\mathrm{CH}_{2} \mathrm{Cl}_{2}(8 \mathrm{~mL})$ at room temperature and 
stirred for $3 \mathrm{~h}$. The reaction mixture was partitioned between $0.5 \mathrm{~mL} \mathrm{Na}_{2} \mathrm{~S}_{2} \mathrm{O}_{3}$ in $10 \mathrm{~mL}$ of $\mathrm{H}_{2} \mathrm{O}$ and $10 \mathrm{~mL} \mathrm{NaHCO}_{3}$ and $\mathrm{CH}_{2} \mathrm{Cl}_{2}(15 \mathrm{~mL})$. The organic layer was dried over anhydrous $\mathrm{MgSO}_{4}$ and evaporated. The residue was column chromatographied (85\% hexane/EtOAc) to give $\mathbf{7 3}^{134}(290 \mathrm{mg}, 91 \%)$ as an oil: ${ }^{1} \mathrm{H} \mathrm{NMR}\left(\mathrm{CDCl}_{3}\right) \delta 0.08(\mathrm{~s}, 6 \mathrm{H}$, $\mathrm{Si} M e_{2}$ ), 0.81 (s, 9H, Si-C-Me ), 1.35 (s, 3H, Me), 1.37 (s, 3H, Me), 3.68 (dd, $J=4.2,11.2$ Hz, 1H, H1), 3.76 (dd, $J=4.0,11.2 \mathrm{~Hz}, 1 \mathrm{H}, \mathrm{H1}$ '), 4.04 (d, $J=17.7 \mathrm{~Hz}, 1 \mathrm{H}, \mathrm{H} 5), 4.20$ (d, $J$ $\left.=17.8 \mathrm{~Hz}, 1 \mathrm{H}, \mathrm{H} 5^{\prime}\right), 4.51-4.53(\mathrm{~m}, 1 \mathrm{H}, \mathrm{H} 2), 4.71(\mathrm{~d}, J=7.8 \mathrm{~Hz}, 1 \mathrm{H}, \mathrm{H} 3), 7.25-7.38(\mathrm{~m}$, $15 \mathrm{H}, \mathrm{Ar})$.

\section{1-O-tert-Butyldimethysilyl-2,3-O-isopropylidene-4- $C$-methyl-5- $O$-trityl-D-ribitol}

(74a). Procedure C. MeMgBr (1 M/THF, $2 \mathrm{~mL}, 2.0 \mathrm{mmol})$ was added to a stirred solution of 73 (205 mg, $0.37 \mathrm{mmol})$ in anhydrous THF $(4 \mathrm{~mL})$ at $-78{ }^{\circ} \mathrm{C}$ under $\mathrm{N}_{2}$ atmosphere. After $15 \mathrm{~min}$, the reaction mixture was allowed to warm up to ambient temperature and was kept stirring for $1 \mathrm{~h}$. The reaction was then quenched by the addition of $\mathrm{MeOH}(1 \mathrm{~mL})$ and diluted with EtOAc $(10 \mathrm{~mL})$. The resulting mixture was washed with $0.1 \mathrm{~N} \mathrm{HCl}$ and the organic layer dried over anhydrous $\mathrm{MgSO}_{4}$. Volatiles were evaporated and the crude residue was then purified by flash column chromatography $(90 \%$ hexane/EtOAc) to give $\mathbf{7 4 a}{ }^{134}(180 \mathrm{mg}, 85 \%)$ as an clear oil: ${ }^{1} \mathrm{H} \mathrm{NMR}\left(\mathrm{CDCl}_{3}\right) \delta 0.08(\mathrm{~s}$, 6H, SiMe $), 0.81$ (s, 9H, Si-C-Me $), 1.35$ (s, 3H, Me, Cla), 1.40 ( 2 x s, 2 x 3H, 2 x Me), $3.01(\mathrm{~d}, J=8.7 \mathrm{~Hz}, 1 \mathrm{H}, \mathrm{H} 5), 3.12$ (d, $\left.J=8.7 \mathrm{~Hz}, 1 \mathrm{H}, \mathrm{H} 5^{\prime}\right), 3.25$ (dd, $J=3.8,10.9 \mathrm{~Hz}$, 1H, H1), 3.70 (dd, $J=3.8,10.9 \mathrm{~Hz}, 1 \mathrm{H}, \mathrm{H1}$ ), 3.90-3.95 (m,1H, H2), 4.40 (d, $J=5.5 \mathrm{~Hz}$, 1H, H3), 7.25-7.38 (m, 15H, Ar). HRMS calcd for $\mathrm{C}_{34} \mathrm{H}_{46} \mathrm{O}_{5} \mathrm{NaSi}^{+}[\mathrm{M}+\mathrm{Na}]^{+}$585.3007, found 585.3009. 


\section{1-O-tert-Butyldimethysilyl-4-C-hexyl-2,3-O-isopropylidene-5-O-trityl-D-ribitol}

(74b). Treatment of 73 (160 mg, $0.29 \mathrm{mmol})$ with hexyl-MgBr $(0.8 \mathrm{M} / \mathrm{THF} ; 1 \mathrm{~mL}, 0.80$ mmol) by Procedure C (flash column chromatography; $80 \%$ hexane/EtOAc) gave 74b $(120 \mathrm{mg}, 64 \%)$ as a clear oil: ${ }^{1} \mathrm{H}$ NMR $\left(\mathrm{CDCl}_{3}\right) \delta 0.08\left(\mathrm{~s}, 6 \mathrm{H}, \mathrm{Si} M e_{2}\right), 0.81$ (s, 9H, Si-C$\left.M e_{3}\right), 0.89$ (t, $\left.J=6.6 \mathrm{~Hz}, \mathrm{CH}_{3}, \mathrm{C} 6 \mathrm{a}\right), 1.30-1.40$ (m, 8H, C2a-C5a), 1.40 (s, 3H, Me), 1.50 (s, 3H, Me), 1.50-1.60 (m, 2H, C1a), $3.06(\mathrm{~d}, J=8.9 \mathrm{~Hz}, 1 \mathrm{H}, \mathrm{H} 5), 3.22(\mathrm{~d}, J=8.9 \mathrm{~Hz}$ $\left.1 \mathrm{H}, \mathrm{H} 5^{\prime}\right), 3.28(\mathrm{dd}, J=3.8,11.1 \mathrm{~Hz}, 1 \mathrm{H}, \mathrm{H} 1), 3.72\left(\mathrm{dd}, J=7.6,11.0 \mathrm{~Hz}, 1 \mathrm{H}, \mathrm{H} 1^{\prime}\right), 3.80-$ $3.85(\mathrm{~m}, 1 \mathrm{H}, \mathrm{H} 2), 4.40(\mathrm{~d}, J=5.2 \mathrm{~Hz}, 1 \mathrm{H}, \mathrm{H} 3), 7.25-7.38(\mathrm{~m}, 15 \mathrm{H}, \mathrm{Ar})$.

\section{1-O-tert-Butyldimethysilyl-2,3-O-isopropylidene-4- $C$-octyl-5- $O$-trityl-D-ribitol}

(74c). Treatment of $73(480 \mathrm{mg}, 0.87 \mathrm{mmol})$ with octyl-MgBr $(2 \mathrm{M} / \mathrm{THF} ; 7.5 \mathrm{~mL}, 15$ mmol) by Procedure $\mathrm{C}$ gave $74 \mathrm{c}(350 \mathrm{mg}, 60 \%)$ as a clear oil: ${ }^{1} \mathrm{H}$ NMR $\left(\mathrm{CDCl}_{3}\right) \delta 0.08$ (s, 6H, SiMe $), 0.81$ (s, 9H, Si-C-Me $), 0.89$ (t, J=6.6 Hz, Me, C8a), 1.28-1.30 (m, 12H, C2a-C7a), 1.38 (s, 3H, Me), 1.42 (s, 3H, Me), 1.50-1.60 (m, 2H, C1a), 3.05 (d, J= 8.9 Hz, 1H, H5), 3.21 (d, $J=8.9$ Hz, 1H, H5'), 3.26 (dd, $J=3.8,11.0$ Hz, 1H, H1), 3.70 (dd, $\left.J=3.9,7.6 \mathrm{~Hz}, 1 \mathrm{H}, \mathrm{H} 1^{\prime}\right), 3.80-3.85(\mathrm{~m}, 1 \mathrm{H}, \mathrm{H} 2), 4.40$ (d, $\left.J=5.2 \mathrm{~Hz}, 1 \mathrm{H}, \mathrm{H} 3\right), 7.25-7.38$ $(\mathrm{m}, 15 \mathrm{H}, \mathrm{Ar})$.

\section{1-O-tert-Butyldimethysilyl-2,3-O-isopropylidene-5- $O$-trityl-4- $C$-vinyl-D-ribitol} (74d). Treatment of 73 (120 mg, $0.21 \mathrm{mmol})$ with vinyl-MgBr (1 M/THF; $0.63 \mathrm{~mL}, 0.63$ mmol) by Procedure $\mathrm{C}$ gave $\mathbf{7 4 d}(70 \mathrm{mg}, 55 \%)$ as a clear oil: ${ }^{1} \mathrm{H} \mathrm{NMR}\left(\mathrm{CDCl}_{3}\right) \delta 0.08(\mathrm{~s}$, 6H, SiMe 2 ), 0.81 (s, 9H, Si-C-Me $), 1.35$ (s, 3H, Me), 1.37 (s, 3H, Me), 2.92 (d, J=9.0 Hz, 1H, H5), 3.12 (d, $J=9.0$ Hz, 1H, H5'), 3.42 (dd, $J=4.5,10.7$ Hz, 1H, H1), 3.80 (dd, $\left.J=8.5,10.7 \mathrm{~Hz}, 1 \mathrm{H}, \mathrm{H} 1^{\prime}\right), 4.00-4.13(\mathrm{~m}, 1 \mathrm{H}, \mathrm{H} 2), 4.69$ (d, $\left.J=6.1 \mathrm{~Hz}, 1 \mathrm{H}, \mathrm{H} 3\right), 5.16$ (dd, $J=1.7,10.9 \mathrm{~Hz}, 1 \mathrm{H}, \mathrm{CH}=\mathrm{CH} H), 5.40(\mathrm{dd}, J=1.8,17.4 \mathrm{~Hz}, 1 \mathrm{H}, \mathrm{CH}=\mathrm{CHH}), 6.20(\mathrm{dd}, J$ 
$=10.9,17.4 \mathrm{~Hz}, 1 \mathrm{H}, \mathrm{CH}=\mathrm{CHH}), 7.25-7.38(\mathrm{~m}, 15 \mathrm{H}, \mathrm{Ar}) ;{ }^{13} \mathrm{C} \mathrm{NMR} \delta-5.40\left(\mathrm{Si}_{2} e_{2}\right)$, $21.02 \& 25.29\left(\mathrm{CMe}_{2}\right), 25.77$ ( $\left.\mathrm{Si}-\mathrm{C}-\mathrm{Me} e_{3}\right), 31.58\left(\mathrm{Si}-\mathrm{C}-\mathrm{Me}_{3}\right), 60.47\left(C-\mathrm{Ph}_{3}\right), 61.98(\mathrm{C} 1)$, 69.13 (C5), 74.87 (C4), 78.15 (C2), 78.45 (C3), 107.87 (CH=CHH), $114.84\left(C-\mathrm{Me}_{2}\right)$, $126.91 \& 127.71 \& 128.87 \& 143.40(\mathrm{Ar}), 138.71(\mathrm{CH}=\mathrm{CHH}), 146.89 ;$ HRMS calcd for $\mathrm{C}_{35} \mathrm{H}_{46} \mathrm{O}_{5} \mathrm{NaSi}^{+}[\mathrm{M}+\mathrm{Na}]^{+}$597.3007, found 597.3006.

\section{1-O-tert-Butyldimethysilyl-2,3-O-isopropylidene-4-C-4-methoxyphenyl-5-O-}

trityl-D-ribitol (74e), Treatment of 73 (165 mg, $0.30 \mathrm{mmol})$ with methoxyphenyl- $\mathrm{MgBr}$ (1 M/THF; $0.89 \mathrm{~mL}, 0.89 \mathrm{mmol})$ by Procedure C gave 74e (190 mg, 96\%) as a clear oil: ${ }^{1} \mathrm{H}$ NMR $\left(\mathrm{CDCl}_{3}\right) \delta 0.08$ (s, 6H, SiMe $), 0.81$ (s, 9H, Si-C-Me $), 1.35$ (s, 3H, Me), 1.37 (s, 3H, Me), 3.01 (d, $J=9.1 \mathrm{~Hz}, 1 \mathrm{H}, \mathrm{H} 5), 3.15$ (d, $J=9.1 \mathrm{~Hz}, 1 \mathrm{H}, \mathrm{H} 5$ '), 3.41 (dd, $J=$ 4.5, $10.8 \mathrm{~Hz}, 1 \mathrm{H}, \mathrm{H} 1$ ), 3.80 (s, $3 \mathrm{H}, \mathrm{CH}_{3} \mathrm{O}$ ), 3.85 (dd, $\left.J=4.5,10.8 \mathrm{~Hz}, 1 \mathrm{H}, \mathrm{H}^{\prime}\right), 4.19-4.22$ (m, 1H, H2), 5.05 (d, $J=6.4 \mathrm{~Hz}, 1 \mathrm{H}, \mathrm{H} 3), 6.85(\mathrm{~d}, J=6.9 \mathrm{~Hz}, 2 \mathrm{H}, \mathrm{Ar}), 7.61(\mathrm{~d}, J=8.9$ $\mathrm{Hz}, 2 \mathrm{H}, \mathrm{Ar}), 7.25-7.38(\mathrm{~m}, 15 \mathrm{H}, \mathrm{Ar})$; HRMS calcd for $\mathrm{C}_{40} \mathrm{H}_{50} \mathrm{O}_{6} \mathrm{NaSi}^{+}[\mathrm{M}+\mathrm{Na}]^{+}$ 677.3269, found 677.3267 .

\section{2,3-O-Isopropylidene-4- $C$-methyl-5- $O$-trityl-D-ribitol (75a). Procedure D. TBAF} (1 M/THF; $0.5 \mathrm{~mL}, 0.5 \mathrm{mmol}$ ) was added to a stirred solution of 74a (183 $\mathrm{mg}, 0.32 \mathrm{mmol})$ in THF $(6 \mathrm{~mL})$ at $0{ }^{\circ} \mathrm{C}$ (ice-bath). After $30 \mathrm{~min}$, the volatiles were evaporated and the resulting residue was washed with $\mathrm{NaHCO}_{3} / \mathrm{H}_{2} \mathrm{O}$ and extracted with EtOAc. The organic layer was then dried over $\mathrm{Mg}_{2} \mathrm{SO}_{4}$ and evaporated to give crude residue which was column chromatographed $\left(80 \rightarrow 70 \%\right.$ hexane/EtOAc) to give 75a $(100 \mathrm{mg}, 68 \%):{ }^{1} \mathrm{H}$ NMR $\left(\mathrm{CDCl}_{3}\right) \delta 1.35\left(\mathrm{~s}, 3 \mathrm{H}, \mathrm{CH}_{3}, \mathrm{Cla}\right), 1.40(\mathrm{~s}, 3 \mathrm{H}, \mathrm{Me}), 1.49(\mathrm{~s}, 3 \mathrm{H}, \mathrm{Me}), 3.05(\mathrm{~d}, J=$ $9.0 \mathrm{~Hz}, 1 \mathrm{H}, \mathrm{H}$ ), 3.32 (d, $\left.J=9.0 \mathrm{~Hz}, 1 \mathrm{H}, \mathrm{H} 5^{\prime}\right), 3.58$ (dd, $\left.J=5.2,12.0 \mathrm{~Hz}, 1 \mathrm{H}, \mathrm{H} 1\right), 3.75$ (dd, $J=5.5,12 \mathrm{~Hz}, 1 \mathrm{H}, \mathrm{H1}$ '), 4.10- $4.20(\mathrm{~m}, 1 \mathrm{H}, \mathrm{H} 2), 4.30(\mathrm{~d}, J=6.2 \mathrm{~Hz}, 1 \mathrm{H}, \mathrm{H} 3), 7.25-$ 
$7.38(\mathrm{~m}, 15 \mathrm{H}, \mathrm{Ar}) ;{ }^{13} \mathrm{C} \mathrm{NMR}\left(\mathrm{CDCl}_{3}\right) \delta 14.21$ (C1a), $25.17 \& 27.28\left(\mathrm{CMe}_{2}\right), 60.42(\mathrm{C} 5)$, $61.43(\mathrm{C} 1), 67.95\left(C-\mathrm{Ph}_{3}\right), 68.38(\mathrm{C} 4), 77.61(\mathrm{C} 2), 79.10(\mathrm{C} 3), 107.67(\mathrm{CMe}), 127.27 \&$ $127.97 \& 128.62 \& 143.43(\mathrm{Ar})$.

2,3-O-Isopropylidene-4- $\boldsymbol{C}$-hexyl-5- $\boldsymbol{O}$-trityl-D-ribitol (75b). Treatment of $\mathbf{7 4 b}(280$ $\mathrm{mg}, 0.44 \mathrm{mmol}$ ) with TBAF by Procedure D gave $\mathbf{7 5 b}(145 \mathrm{mg}, 87 \%)$ as an viscous oil: ${ }^{1} \mathrm{H}$ NMR $\left(\mathrm{CDCl}_{3}\right) \delta 0.85$ (t, $\left.J=6.6 \mathrm{~Hz}, \mathrm{Me}, \mathrm{C} 6 \mathrm{a}\right), 1.30-1.40$ (m, 8H, C2a-C5a), 1.25 (s, 3H, Me), 1.40 (s, 3H, Me), 1.50-1.60 (m, 2H, C1a), 2.91 (d, $J=9.3 \mathrm{~Hz}, 1 \mathrm{H}, \mathrm{H} 5), 3.20$ (d, $\left.J=9.3 \mathrm{~Hz}, 1 \mathrm{H}, \mathrm{H} 5^{\prime}\right), 3.30(\mathrm{dd}, J=5.0,12.2 \mathrm{~Hz}, 1 \mathrm{H}, \mathrm{H} 1), 3.40(\mathrm{dd}, J=5.0,12.0 \mathrm{~Hz}, 1 \mathrm{H}$, H1'), 3.79-3.82 (q, $J=5.8 \mathrm{~Hz}, 1 \mathrm{H}, \mathrm{H} 2), 4.15$ (d, $J=5.8 \mathrm{~Hz}, 1 \mathrm{H}, \mathrm{H} 3), 7.25-7.38$ (m, 15 $\mathrm{Hz}, \mathrm{Ar}) ;{ }^{13} \mathrm{C} \mathrm{NMR}\left(\mathrm{CDCl}_{3}\right) \delta 14.14$ (C6a), 22.66, 23.54, 25.45, 27.57 (C2a-C5a), $29.74 \&$ $31.83\left(\mathrm{CMe} e_{2}\right), 36.05$ (C1a), $61.71(\mathrm{C} 5), 65.39(\mathrm{C} 1), 72.06\left(C-\mathrm{Ph}_{3}\right), 77.55(\mathrm{C} 4), 78.99$ (C2), 86.92 (C3), $107.21\left(\mathrm{CMe}_{2}\right), 127.31 \& 127.96 \& 128.65$ \& 145.26 (Ar); HRMS calcd for $\mathrm{C}_{33} \mathrm{H}_{42} \mathrm{O}_{5} \mathrm{Na}^{+}[\mathrm{M}+\mathrm{Na}]^{+}$541.2924, found 541.2924.

2,3-O-Isopropylidene-4- $C$-octyl-5- $O$-trityl-D-ribitol (75c). Treatment of $74 \mathrm{c}$ (350 $\mathrm{mg}, 0.52 \mathrm{mmol}$ ) with TBAF by Procedure D gave 75c (200 mg, 84\%) as an viscous oil. ${ }^{1} \mathrm{H}$ NMR $\left(\mathrm{CDCl}_{3}\right) \delta 0.80$ (t, $\left.J=6.6 \mathrm{~Hz}, \mathrm{CH}_{3}, \mathrm{C} 8 \mathrm{a}\right), 1.20$ (s, 12H, C2a-C7a), 1.29 (s, 3H, Me), 1.40 (s, Me), 1.50-1.60 (m, 2H, C1a), 2.95 (d, $J=9.4 \mathrm{~Hz}, 1 \mathrm{H}, \mathrm{H} 5), 3.25$ (d, $J=$ $9.3 \mathrm{~Hz}, 1 \mathrm{H}, \mathrm{H} 5$ '), 3.35 (dd, $J=4.92,12.2 \mathrm{~Hz}, 1 \mathrm{H}, \mathrm{H} 1), 3.45$ ( dd, $J=5.4,12.2 \mathrm{~Hz}, 1 \mathrm{H}$, $\mathrm{H} 1$ '), 3.80 (m, 1H, H2), 4.10 ( $\mathrm{d}, J=5.8 \mathrm{~Hz}, 1 \mathrm{H}, \mathrm{H} 3), 7.25-7.38$ (m, 15H, Ar); ${ }^{13} \mathrm{C}$ NMR $\left(\mathrm{CDCl}_{3}\right) \delta 14.11$ (C8a), 22.68, 23.09, 25.43, 27.55, 28.42, 29.24 (C2a-C7a), $29.56 \&$ $30.08(\mathrm{CMe}), 36.06$ (C1a), 61.89 (C5), $64.24(\mathrm{C} 1), 66.95\left(\mathrm{C}-\mathrm{Ph}_{3}\right), 74.36(\mathrm{C} 4), 77.61$ (C2), 79.18 (C3), $107.20\left(\mathrm{CMe}_{2}\right), 126.91 \& 127.71 \& 128.87 \& 143.40$ (Ar); HRMS calcd for $\mathrm{C}_{35} \mathrm{H}_{46} \mathrm{O}_{5} \mathrm{Na}^{+}[\mathrm{M}+\mathrm{Na}]^{+}$569.3237, found 569.3237 . 
2,3-O-Isopropylidene-4- $\boldsymbol{C}$-vinyl-5-O-trityl-D-ribitol (75d). Treatment of 74d (200 mg, $0.34 \mathrm{mmol}$ ) with TBAF by Procedure D gave 75d (124mg, 77\%) as a viscous oil: ${ }^{1} \mathrm{H}$ NMR $\left(\mathrm{CDCl}_{3}\right) \delta 1.35$ (s, 3H, Me), 1.37 (s, 3H, Me), 3.38 (d, $\left.J=11.2 \mathrm{~Hz}, 1 \mathrm{H}, \mathrm{H} 5\right), 3.54$ (d, $\left.J=11.2 \mathrm{~Hz}, 1 \mathrm{H}, \mathrm{H} 5^{\prime}\right), 3.58$ (dd, $\left.J=5.1,11.3 \mathrm{~Hz}, 1 \mathrm{H}, \mathrm{H} 1\right), 3.90$ (d, $J=8.6,11.3 \mathrm{~Hz}$, 1H, H1'), 4.25-4.30 (m, 1H, H2), 4.32 (d, $J=6.5 \mathrm{~Hz}, 1 \mathrm{H}, \mathrm{H} 3), 5.20$ (dd, $J=1.2,11.0 \mathrm{~Hz}$, $1 \mathrm{H}, \mathrm{CH}=\mathrm{CH} H), 5.40(\mathrm{dd}, J=1.5,17.6 \mathrm{~Hz}, 1 \mathrm{H}, \mathrm{CH}=\mathrm{CHH}), 6.20(\mathrm{dd}, J=11.0,17.5 \mathrm{~Hz}$, $1 \mathrm{H}, \mathrm{CH}=\mathrm{CHH}), 7.25-7.38(\mathrm{~m}, 15 \mathrm{H}, \mathrm{Ar}) .{ }^{13} \mathrm{C} \mathrm{NMR}\left(\mathrm{CDCl}_{3}\right) \delta 24.65 \& 27.07\left(\mathrm{C}-\mathrm{Me}_{2}\right)$, $60.29\left(\mathrm{CPh}_{3}\right), 60.62(\mathrm{C} 1), 68.07$ (C5), $77.90(\mathrm{C} 2), 78.10(\mathrm{C} 4), 82.01(\mathrm{C} 3), 115.48$ (C$\left.\mathrm{Me}_{2}\right), \quad 116.03(\mathrm{CH}=\mathrm{CHH}), \quad 126.82 \quad \& \quad 127.65 \quad \& \quad 128.75 \quad \& \quad 143.28 \quad(\mathrm{Ar}), 146.88$ $(\mathrm{CH}=\mathrm{CHH})$.

2,3-O-Isopropylidene-4-C-4-methoxyphenyl-5-O-trityl-D-ribitol (75e). Treatment of 74e (190 mg, $0.29 \mathrm{mmol})$ with TBAF by Procedure D gave $75 \mathbf{e}(92 \mathrm{mg}, 59 \%)$ as a viscous oil: ${ }^{1} \mathrm{H}$ NMR $\left(\mathrm{CDCl}_{3}\right) \delta 1.35$ (s, 3H, Me), 1.37 (s, 3H, Me), 3.01 (dd, $J=6.0$, $11.7 \mathrm{~Hz}, 1 \mathrm{H}, \mathrm{H1}$ ), 3.03 (d, $J=9.0 \mathrm{~Hz}, 1 \mathrm{H}, \mathrm{H} 5), 3.23$ (dd, $J=6.0,11.7 \mathrm{~Hz}, 1 \mathrm{H}, \mathrm{H1}$ '), 3.45 (d, $\left.J=9.0 \mathrm{~Hz}, 1 \mathrm{H}, \mathrm{H}^{\prime}\right), 3.72\left(\mathrm{~s}, 3 \mathrm{H}, \mathrm{CH}_{3} \mathrm{O}\right), 4.19-4.22(\mathrm{~m}, 1 \mathrm{H}, \mathrm{H} 2), 4.75(\mathrm{~d}, J=6.6 \mathrm{~Hz}$, 1H, H3), $6.85(\mathrm{~d}, J=6.9 \mathrm{~Hz}, 2 \mathrm{H}, \mathrm{Ar}), 7.61(\mathrm{~d}, J=8.9 \mathrm{~Hz}, 2 \mathrm{H}, \mathrm{Ar}), 7.25-7.38(\mathrm{~m}, 15 \mathrm{H}$, Ar); ${ }^{13} \mathrm{C}$ NMR $\delta 24.58 \& 27.02\left(\mathrm{C}-\mathrm{Me}_{2}\right), 55.19\left(\mathrm{CH}_{3} \mathrm{O}\right), 60.04\left(\mathrm{CPh}_{3}\right), 61.28(\mathrm{C} 1), 69.73$ (C5), 78.08 (C2), 79.05 (C3), 82.02 (C4), $113.48\left(C-\mathrm{Me}_{2}\right)$, 127.25, 127.37, 127.92, $159.10(\mathrm{Ar}), 128.57 \& 129.68 \& 132.91 \& 146.88(\mathrm{Ar})$.

\section{2,3-O-Isopropylidene-4- $C$-methyl-5- $O$-trityl-D-ribono-1,4-lactone}

(76a).

Procedure E. $N$-methylmorpholine $\quad N$-oxide $\quad(\mathrm{NMO} ; 50 \quad \mathrm{mg}, \quad 0.42 \quad \mathrm{mmol}$ ), tetrapropylammonium perrenthenate (TPAP; $1 \mathrm{mg}, 0.002 \mathrm{mmol}$ ) and $4 \AA$ molecular sieves $\left(100 \mathrm{mg}\right.$ ) were added to a stirred solution of $75 \mathrm{a}(51 \mathrm{mg}, 0.11 \mathrm{mmol})$ in $\mathrm{CH}_{2} \mathrm{Cl}_{2}$ 
$\left(3.7 \mathrm{~mL}\right.$ ) at ambient temperature under $\mathrm{N}_{2}$ atmosphere. After $6 \mathrm{~h}$, the reaction mixture was filtered off and the filtrate was dried over $\mathrm{MgSO}_{4}$ and evaporated. The residue was purified by flash column chromatography ( $75 \rightarrow 50 \%$ hexane/EtOAc) to give 76 a (40 $\mathrm{mg}, 80 \%):{ }^{1} \mathrm{H}$ NMR $\left(\mathrm{CDCl}_{3}\right) \delta 1.30$ (s, 3H, C1a), 1.35 (s, 3H, Me), 1.40 (s, 3H, Me), 2.91 (d, $J=10.2 \mathrm{~Hz}, 1 \mathrm{H}, \mathrm{H} 5), 3.50$ (d, $\left.J=10.2 \mathrm{~Hz}, \mathrm{H} 1, \mathrm{H} 5^{\prime}\right), 4.20$ (d, $\left.J=5.6 \mathrm{~Hz}, 1 \mathrm{H}, \mathrm{H} 2\right)$, $5.01(\mathrm{~d}, J=5.6 \mathrm{~Hz}, 1 \mathrm{H}, \mathrm{H} 3), 7.25-7.38(\mathrm{~m}, 15 \mathrm{~Hz}, \mathrm{Ar}) .{ }^{13} \mathrm{C} \mathrm{NMR}\left(\mathrm{CDCl}_{3}\right) \delta 16.40(\mathrm{Cla})$ $25.90 \& 26.78\left(\mathrm{C}-\mathrm{Me}_{2}\right), 66.65\left(\mathrm{CPh}_{3}\right), 67.63(\mathrm{C} 5), 77.70(\mathrm{C} 2), 79.77(\mathrm{C} 3), 88.56(\mathrm{C} 4)$, $126.07\left(C-\mathrm{Me}_{2}\right), 127.46 \& 128.25 \& 128.67 \& 146.87$ (Ar), 172.07 (C1).

2,3-O-Isopropylidene-4- $C$-hexyl-5- $O$-trityl-D-ribono-1,4-lactone (76b). Treatment of 75b (37 mg, $0.09 \mathrm{mmol})$ with NMO/TPAP by Procedure E gave 76b (35 mg, 94\%): ${ }^{1} \mathrm{H}$ NMR $\left(\mathrm{CDCl}_{3}\right) \delta 0.80(\mathrm{t}, J=6.6 \mathrm{~Hz}, 3 \mathrm{H}, \mathrm{C} 6 \mathrm{a}), 1.19-1.21(\mathrm{~m}, 8 \mathrm{H}, \mathrm{C} 2 \mathrm{a}-\mathrm{C} 5 \mathrm{a}), 1.24(\mathrm{~s}, 3 \mathrm{H}$, Me), 1.40 (s, 3H, Me), 1.50-1.60 (m, 2H, C1a), 2.85 (d, $J=10.2 \mathrm{~Hz}, 1 \mathrm{H}, \mathrm{H} 5), 3.51$ (d, $J=$ $\left.10.2 \mathrm{~Hz}, 1 \mathrm{H}, \mathrm{H} 5^{\prime}\right), 4.10(\mathrm{~d}, J=5.6 \mathrm{~Hz}, 1 \mathrm{H}, \mathrm{H} 2), 5.01(\mathrm{~d}, J=5.6 \mathrm{~Hz}, 1 \mathrm{H}, \mathrm{H} 3), 7.25-7.38$ $(\mathrm{m}, 15 \mathrm{~Hz}) ;{ }^{13} \mathrm{C}$ NMR $\left(\mathrm{CDCl}_{3}\right) \delta 13.98$ (C6a), $23.33 \& 26.76\left(\mathrm{C}-\mathrm{Me}_{2}\right), 29.69,31.38$, 29.42, 29.52 (C2a-C5a), 31.60 (C1a), $66.15\left(\mathrm{CPh}_{3}\right), 66.29$ (C5), 77.21 (C2), 80.11 (C3), $88.25(\mathrm{C} 4), 112.92\left(\mathrm{C}-\mathrm{Me}_{2}\right), 127.36 \& 128.32 \& 128.67 \& 142.85(\mathrm{Ar}), 174.41(\mathrm{C} 1)$.

2,3-O-Isopropylidene-4- $C$-octyl-5- $O$-trityl-D-ribono-1,4-lactone (76c). Treatment of 75c (12 mg, $0.02 \mathrm{mmol})$ with NMO/TPAP by Procedure E gave 76c $(8 \mathrm{mg}, 95 \%):{ }^{1} \mathrm{H}$ NMR $\left(\mathrm{CDCl}_{3}\right) \delta$ 0.80-0.84 (m, Me, C8a), 1.10-1.20 (s, 12H, C2a-C7a), 1.25 (s, Me), 1.40 (s, Me), 1.50-1.60 (m, C1a), 2.90 (d, $J=10.1 \mathrm{~Hz}, 1 \mathrm{H}, \mathrm{H} 5), 3.55$ (d, $J=10.2 \mathrm{~Hz}, 1 \mathrm{H}$, $\left.\mathrm{H}^{\prime}\right), 4.10(\mathrm{~d}, J=5.6 \mathrm{~Hz}, 1 \mathrm{H}, \mathrm{H} 2), 5.01$ (d, $\left.J=5.6 \mathrm{~Hz}, 1 \mathrm{H}, \mathrm{H} 3\right), 7.25-7.38$ (m, 15H, Ar); ${ }^{13} \mathrm{C}$ NMR $\left(\mathrm{CDCl}_{3}\right) \delta 13.2$ (C8a), $21.79 \& 22.61\left(\mathrm{CMe}_{2}\right), 25.05,25.07,28.23,28.39$, 29.20, 29.25 (C2-C7), 30.98 (C1a), $64.91\left(\mathrm{CPh}_{3}\right), 65.06$ (C5), 65.44 (C2), 79.25 (C3), 
87.41 (C4), $112.07\left(\mathrm{CMe}_{2}\right), 126.56 \& 127.30 \& 127.67 \& 142.09$ (Ar), 170.21 (C1); MS $\left(\mathrm{ESI}^{+}\right) \mathrm{m} / z 560\left(\mathrm{M}+\mathrm{NH}_{4}\right)$.

Note When $\mathbf{7 6} \mathbf{c}$ is left in solution overnight, a second minor product $\mathbf{7 6} \mathbf{c}$ appeared to be formed with a ratio of $\mathbf{7 6}^{\prime} \mathbf{c}: \mathbf{7 6 c}(1: 3)$; the ribosyl peaks for the $\mathbf{7 6} \mathbf{c}^{\prime}$ product were as followed: ${ }^{1} \mathrm{H}$ NMR $\left(\mathrm{CDCl}_{3}\right) \delta 3.75(\mathrm{~d}, J=11.6 \mathrm{~Hz}, 1 \mathrm{H}, \mathrm{H} 5$ '), $3.91(\mathrm{~d}, J=11.6 \mathrm{~Hz}, 1 \mathrm{H}$, H5), ), 4.60 (d, $J=5.6 \mathrm{~Hz}, 1 \mathrm{H}, \mathrm{H} 2), 4.90(\mathrm{~d}, J=5.6 \mathrm{~Hz}, 1 \mathrm{H}, \mathrm{H} 3)$; MS (ESI $\left.{ }^{+}\right) m / z 605$ $\left(\mathrm{M}+2 \mathrm{Na}^{+}\right)$.

2,3-O-Isopropylidene-5- $O$-trityl-4- $C$-vinyl-D-ribono-1,4-lactone (76d). Treatment of 75d (100 mg, $0.21 \mathrm{mmol}$ ) with NMO/TPAP by Procedure E gave 76d (90 mg, 95\%): ${ }^{1} \mathrm{H} \mathrm{NMR}\left(\mathrm{CDCl}_{3}\right) \delta 1.22$ (s, 3H, Me), 1.26 (s, 3H, Me), 2.91 (d, $\left.J=10.2 \mathrm{~Hz}, 1 \mathrm{H}, \mathrm{H} 5\right)$, 3.50 (d, $\left.J=10.3 \mathrm{~Hz}, \mathrm{H} 1, \mathrm{H} 5^{\prime}\right), 4.20$ (d, $\left.J=5.6 \mathrm{~Hz}, 1 \mathrm{H}, \mathrm{H} 2\right), 5.00$ (d, $\left.J=5.6 \mathrm{~Hz}, 1 \mathrm{H}, \mathrm{H} 3\right)$, $5.21(\mathrm{~d}, J=11.2 \mathrm{~Hz}, 1 \mathrm{H}, \mathrm{CH}=\mathrm{CH} H), 5.34(\mathrm{~d}, J=17.4 \mathrm{~Hz}, 1 \mathrm{H}, \mathrm{CHH}), 5.61(\mathrm{dd}, J=11.2$, $17.4 \mathrm{~Hz}, \mathrm{CH}=\mathrm{CHH}), 7.25-7.38$ (m, $15 \mathrm{H}) .{ }^{13} \mathrm{C} \mathrm{NMR}\left(\mathrm{CDCl}_{3}\right) \delta 25.92 \& 26.64\left(\mathrm{CMe}_{2}\right)$, $53.50\left(\mathrm{CPh}_{3}\right), 65.50(\mathrm{C} 5), 80.01(\mathrm{C} 2), 82.03(\mathrm{C} 3), 88.87(\mathrm{C} 4), 112.03(\mathrm{CH}=\mathrm{CHH})$, $118.50\left(C-\mathrm{Me}_{2}\right), 127.29 \& 127.95 \& 129.69 \& 145.01(\mathrm{Ar}), 146.85(\mathrm{CH}=\mathrm{CHH}), 174.14$ (C1); HRMS (TOF) $m / z$ calcd for $\mathrm{C}_{29} \mathrm{H}_{28} \mathrm{O}_{5}{ }^{+}[\mathrm{M}+\mathrm{Na}]^{+} 479.1829$, found 479.1829 .

\section{2,3-O-Isopropylidene-4-C-4-methoxyphenyl-5- $O$-trityl-D-ribono-1,4-lactone}

(76e). Treatment of 75e $(90 \mathrm{mg}, 0.16 \mathrm{mmol})$ with NMO/TPAP by Procedure E gave 76e (73 mg, 82\%): ${ }^{1} \mathrm{H}$ NMR $\left(\mathrm{CDCl}_{3}\right) \delta 1.22$ (s, 3H, Me), 1.25 (s, 3H, Me), 3.25 (d, $J=10.5$ Hz, 1H, H5'), 3.35 (d, $J=10.5 \mathrm{~Hz}, 1 \mathrm{H}, \mathrm{H} 5), 3.80$ (s, $\left.3 \mathrm{H}, \mathrm{CH}_{3} \mathrm{O}\right), 4.48$ (d, $J=5.5 \mathrm{~Hz}, 1 \mathrm{H}$, H2), $5.20(\mathrm{~d}, J=5.5 \mathrm{~Hz}, 1 \mathrm{H}, \mathrm{H} 3), 6.82(\mathrm{~d}, J=8.8 \mathrm{~Hz}, 2 \mathrm{H}, \mathrm{Ar}), 7.12(\mathrm{~d}, J=9.7 \mathrm{~Hz}, 2 \mathrm{H}$, Ar), 7.25- $7.38(\mathrm{~m}, 15 \mathrm{H}, \mathrm{Ar}) ;{ }^{13} \mathrm{C} \mathrm{NMR}\left(\mathrm{CDCl}_{3}\right) \delta 25.92 \& 26.64\left(\mathrm{CMe}_{2}\right), 55.18\left(\mathrm{CH}_{3} \mathrm{O}\right)$, 
$62.94\left(\mathrm{CPh}_{3}\right), 68.79(\mathrm{C} 5), 80.77(\mathrm{C} 2), 88.53(\mathrm{C} 3), 88.87(\mathrm{C} 4), 113.60(\mathrm{CMe}), 126.9 \&$

$127.25 \& 128.75 \& 159.10,(\mathrm{Ar}), 128.57 \& 129.68 \& 132.91 \&-146.40$ (Ar), 174.14 (C1).

Attempts to synthesize 4-C-octyl-D-ribono-1,4-hemiacetal (81c) by the Swern oxidation of 4-C-alkyl-D-ribitol (75c): To a solution of oxalyl chloride $(0.01 \mathrm{mg}$, $0.0001 \mathrm{mmol}, 0.013 \mathrm{~mL})$ and DMSO $(0.02 \mathrm{mg}, 0.0002 \mathrm{mmol}, 0.02 \mathrm{~mL})$ in dry $\mathrm{CH}_{2} \mathrm{Cl}_{2}$ $(0.14 \mathrm{~mL})$ at $-60{ }^{\circ} \mathrm{C}$ for $15 \mathrm{~min}$, was added dropwise the solution of $75 \mathbf{c}(70 \mathrm{mg}, 0.13$ mmol) in $\mathrm{CH}_{2} \mathrm{Cl}_{2}(0.14 \mathrm{~mL})$. The reaction was stirred for $15 \mathrm{~min}$ and dry triethylamine (0.06 mg, $0.006 \mathrm{mmol}, 95 \mu \mathrm{L}$ ) was over a period of $10 \mathrm{~min}$ at $-60{ }^{\circ} \mathrm{C}$. The mixture was extracted with $\mathrm{H}_{2} \mathrm{O}$ and $\mathrm{CH}_{2} \mathrm{Cl}_{2}$. The organic layer was washed with brine, dried over $\mathrm{MgSO}_{4}$, and evaporated. Purification on silica gel column (hexane/EtOAc, 8:2) gave a mixture of products ( $\approx 10 \mathrm{mg}$ ) with distinguishable sugar peaks.

2,3-O-Isopropylidene-4- $C$-methyl-D-ribono-1,4-lactone (84a). Procedure F. TFA $(0.22 \mathrm{~mL})$ and $\mathrm{CH}_{2} \mathrm{Cl}_{2}(4 \mathrm{~mL})$ were added to a stirred solution of $76 \mathbf{a}(40 \mathrm{mg}, 0.009$ mmol) at ambient temperature for $5 \mathrm{~h}$. The volatiles were evaporated and residue coevaporated with toluene. The oily residue was partitioned between aqueous $\mathrm{NaHCO}_{3}$ and $\mathrm{CH}_{2} \mathrm{Cl}_{2}$. The separated organic layer was washed with brine, dried $\mathrm{MgSO}_{4}$, and evaporated. Purification on silica gel column (hexane/EtOAc, 8:2) gave 84a (12 mg, 66\%): ${ }^{1} \mathrm{H} \mathrm{NMR}\left(\mathrm{CDCl}_{3}\right) \delta 1.32$ (s, 3H, C1a), 1.35 (s, 3H, Me), 1.42 (s, 3H, Me), 3.60 (d, $J$ $\left.=11.6 \mathrm{~Hz}, 1 \mathrm{H}, \mathrm{H} 5), 3.71(\mathrm{~d}, J=11.6 \mathrm{~Hz}, \mathrm{H1}, \mathrm{H} 5)^{\prime}\right), 4.55$ (d, $\left.J=5.6 \mathrm{~Hz}, 1 \mathrm{H}, \mathrm{H} 2\right), 4.90$ (d, $J=5.6 \mathrm{~Hz}, 1 \mathrm{H}, \mathrm{H} 3) .{ }^{13} \mathrm{C} \mathrm{NMR}\left(\mathrm{CDCl}_{3}\right) \delta 16.42(\mathrm{C} 1 \mathrm{a}), 25.81 \& 26.76\left(\mathrm{CMe}_{2}\right), 67.61(\mathrm{C} 5)$, 77.82 (C2), 80.01 (C3), 86.35 (C4), $113.02\left(\mathrm{CMe}_{2}\right), 174.46$ (CO); HRMS (TOF) $\mathrm{m} / \mathrm{z}$ calcd for $\mathrm{C}_{9} \mathrm{H}_{14} \mathrm{O}_{5} \mathrm{Na}^{+}[\mathrm{M}+\mathrm{Na}]^{+} 225.0733$, found 225.0734. 
Isopropylidene-4- $\boldsymbol{C}$-hexyl-D-ribono-1,5-lactone (88b). Treatment of 76b (30 mg, 0.058 mmol) with TFA by Procedure F (flash column chromatography; $80 \%$ hexane/EtOAc) gave 84b (12 mg, 80\%): ${ }^{1} \mathrm{H}$ NMR $\left(\mathrm{CDCl}_{3}\right) \delta 0.80\left(\mathrm{t}, J=6.6 \mathrm{~Hz}, \mathrm{CH}_{3}, \mathrm{C} 6 \mathrm{a}\right), 1.19-1.21(\mathrm{~m}$, $8 \mathrm{H}, \mathrm{C} 2 \mathrm{a}-\mathrm{C} 5 \mathrm{a}), 1.41$ (s, 3H, Me), 1.50 (s, 3H, Me), 1.50-1.60 (m, 2H, C1a), 3.75 (d, J= $11.8 \mathrm{~Hz}, 1 \mathrm{H}, \mathrm{H} 5), 3.85$ (d, $\left.J=11.4 \mathrm{~Hz}, 1 \mathrm{H}, \mathrm{H} 5^{\prime}\right), 4.65$ (d, $\left.J=5.6 \mathrm{~Hz}, 1 \mathrm{H}, \mathrm{H} 2\right), 4.96$ (d, $J$ $=5.6 \mathrm{~Hz}, 1 \mathrm{H}, \mathrm{H} 3) .{ }^{13} \mathrm{C} \mathrm{NMR}\left(\mathrm{CDCl}_{3}\right) \delta 13.97$ (C6a), $23.43 \& 25.79\left(\mathrm{CMe}_{2}\right), 29.41$, 29.56, 29.71, 31.14 (C2a-C5a), 31.91 (C1a), 77.20 (C5), 71.89 (C2), 80.63 (C3), 89.73 (C4), $112.85\left(C \mathrm{Me}_{2}\right), 172.45(\mathrm{CO})$; HRMS (TOF) $\mathrm{m} / z$ calcd for $\mathrm{C}_{14} \mathrm{H}_{24} \mathrm{O}_{5} \mathrm{Na}^{+}[\mathrm{M}+\mathrm{Na}]^{+}$ 295.1516, found 295.1516.

Note: When the reaction of $\mathbf{7 6 b}$ with TFA was kept overnight, the mixture of $\mathbf{8 4 b}$ and its D-ribono-1,5-lactone (88b) was isolated after column chromatography $(\mathbf{8 4 b} / \mathbf{8 8 b}, 1: 1$, $12 \mathrm{mg}, 80 \%)$. The ribosyl peaks for the $\mathbf{8 8 b}$ product were as followed: ${ }^{1} \mathrm{H}$ NMR $\left(\mathrm{CDCl}_{3}\right)$ $\delta 3.95(\mathrm{~d}, J=12.7 \mathrm{~Hz}, 1 \mathrm{H}, \mathrm{H} 5), 4.20$ (d, $\left.J=12.7 \mathrm{~Hz}, 1 \mathrm{H}, \mathrm{H} 5^{\prime}\right), 4.22(\mathrm{~d}, J=2.4 \mathrm{~Hz}, 1 \mathrm{H}$, $\mathrm{H} 2), 4.37(\mathrm{dd}, J=0.9,2.5 \mathrm{~Hz}, 1 \mathrm{H}, \mathrm{H} 3) ;{ }^{13} \mathrm{C} \mathrm{NMR}\left(\mathrm{CDCl}_{3}\right) \delta 14.08(\mathrm{C} 6 \mathrm{a}), 22.67 \& 23.54$ $(\mathrm{CMe}), 26.78,27.05,31.6,31.59$ (C2a-C5a), 37.07 (C1a), 65.83 (C5), 69.06 (C2), 79.76 (C3), 87.97 (C4), $128.54\left(\mathrm{CMe}_{2}\right), 142.95(\mathrm{C} 1)$.

2,3-O-Isopropylidene-4-C-octyl-D-ribono-1,4-lactone (84c). Treatment of $76 \mathrm{c}$ (35 $\mathrm{mg}, 0.064 \mathrm{mmol})$ with TFA by Procedure F gave 84c $(16 \mathrm{mg}, 75 \%):{ }^{1} \mathrm{H} \mathrm{NMR}\left(\mathrm{CDCl}_{3}\right) \delta$ $0.80\left(\mathrm{t}, J=6.6 \mathrm{~Hz}, \mathrm{CH}_{3}, \mathrm{C} 8 \mathrm{a}\right), 1.30-1.32(\mathrm{~m}, 12 \mathrm{H}, \mathrm{C} 2 \mathrm{a}-\mathrm{C} 7 \mathrm{a}), 1.40$ (s, 3H, Me), 1.50 (s, $3 \mathrm{H}, \mathrm{Me}), 1.50-1.60(\mathrm{~m}, 2 \mathrm{H}, \mathrm{Cla}), 3.75$ (d, $J=11.6 \mathrm{~Hz}, 1 \mathrm{H}, \mathrm{H} 5), 3.85$ (d, $J=11.6 \mathrm{~Hz}$, $\left.1 \mathrm{H}, \mathrm{H} 5^{\prime}\right), 4.65(\mathrm{~d}, J=5.6 \mathrm{~Hz}, 1 \mathrm{H}, \mathrm{H} 2), 4.95(\mathrm{~d}, J=5.6 \mathrm{~Hz}, 1 \mathrm{H}, \mathrm{H} 3) ;{ }^{13} \mathrm{C} \mathrm{NMR}\left(\mathrm{CDCl}_{3}\right) \delta$ $14.08\left(\mathrm{CH}_{3}, \mathrm{C} 8 \mathrm{a}\right), 22.63 \& 23.46\left(\mathrm{CMe}_{2}\right), 25.81,26.74,29.12,29.24,30.04,31.14$ (C2a- 
C7a), 31.82 (C1a), 65.89 (C5), 77.31 (C2), 79.74 (C3), 88.53 (C4), $112.07\left(\mathrm{CMe}_{2}\right)$, 174.57 (C1); HRMS (TOF) $\mathrm{m} / z$ calcd for $\mathrm{C}_{16} \mathrm{H}_{28} \mathrm{O}_{5} \mathrm{Na}^{+}$[M+Na] 323.1829 , found: 323.1915 .

2,3-O-Isopropylidene-4- $C$-vinyl-D-ribono-1,4-lactone (84d). Treatment of 76d (30 mg, 0.065 mmol) with TFA by Procedure F (flash column chromatography; $80 \%$ hexane/EtOAc) gave somehow an unstable product $84 d(5 \mathrm{mg}, 35 \%):{ }^{1} \mathrm{H} \mathrm{NMR}\left(\mathrm{CDCl}_{3}\right) \delta$ 1.22 (s, 3H, Me), 1.26 (s, 3H, Me), 3.61 (d, $J=11.7 \mathrm{~Hz}, 1 \mathrm{H}, \mathrm{H} 5), 3.65$ (d, $J=11.8 \mathrm{~Hz}$, 1H, H5'), 4.60 (d, $J=5.6 \mathrm{~Hz}, 1 \mathrm{H}, \mathrm{H} 2), 4.82(\mathrm{~d}, J=5.6 \mathrm{~Hz}, 1 \mathrm{H}, \mathrm{H} 3), 5.24(\mathrm{~d}, J=11.3$ $\mathrm{Hz}, 1 \mathrm{H}, \mathrm{CH}=\mathrm{CH} H), 5.34(\mathrm{~d}, J=17.5 \mathrm{~Hz}, 1 \mathrm{H}, \mathrm{C}=\mathrm{CH} H), 5.71(\mathrm{dd}, J=11.2,17.5 \mathrm{~Hz}$, $\mathrm{CH}=\mathrm{CHH}) ;{ }^{13} \mathrm{C} \mathrm{NMR}\left(\mathrm{CDCl}_{3}\right) \delta 25.87,26.70\left(\mathrm{CMe}_{2}\right), 66.37$ (C5), $76.70(\mathrm{C} 2), 80.01$ (C3), $87.95(\mathrm{C} 4), 113.29\left(\mathrm{CMe}_{2}\right), 118.21\left(\mathrm{CH}=\mathrm{CH}_{2}\right), 130.53\left(\mathrm{CH}=\mathrm{CH}_{2}\right), 174.06(\mathrm{CO})$; HRMS (TOF) $m / z$ calcd for $\mathrm{C}_{10} \mathrm{H}_{14} \mathrm{O}_{5} \mathrm{Na}^{+}[\mathrm{M}+\mathrm{Na}]^{+} 237.0733$, found 237.0733 .

\section{2,3-O-Isopropylidene-4-C-4-methoxyphenyl-D-ribono-1,4-lactone}

(84e). Treatment of 76e $(70 \mathrm{mg}, 0.13 \mathrm{mmol})$ with TFA by Procedure F (flash column chromatography; $80 \%$ hexane/EtOAc) gave somehow an unstable product $\mathbf{8 4 d}(20 \mathrm{mg}$, 60\%): ${ }^{1} \mathrm{H}$ NMR $\left(\mathrm{CDCl}_{3}\right) \delta 1.22(\mathrm{~s}, 3 \mathrm{H}, \mathrm{Me}), 1.25(\mathrm{~s}, 3 \mathrm{H}, \mathrm{Me}), 3.80\left(\mathrm{~s}, 3 \mathrm{H}, \mathrm{CH}_{3} \mathrm{O}\right), 3.85$ (d, $J=12.3 \mathrm{~Hz}, 1 \mathrm{H}, \mathrm{H} 5), 3.95$ (d, $\left.J=12.5 \mathrm{~Hz}, 1 \mathrm{H}, \mathrm{H} 5{ }^{\prime}\right), 4.95$ (d, $\left.J=5.4 \mathrm{~Hz}, 1 \mathrm{H}, \mathrm{H} 2\right)$, $5.15(\mathrm{~d}, J=5.3 \mathrm{~Hz}, 1 \mathrm{H}, \mathrm{H} 3), 6.82(\mathrm{~d}, J=8.8 \mathrm{~Hz}, 2 \mathrm{H}, \mathrm{Ar}), 7.12(\mathrm{~d}, J=9.0 \mathrm{~Hz}, 2 \mathrm{H}, \mathrm{Ar})$;

${ }^{13} \mathrm{C}$ NMR $\left(\mathrm{CDCl}_{3}\right) \delta 25.83 \& 26.65\left(\mathrm{CMe}_{2}\right), 55.25\left(\mathrm{CH}_{3} \mathrm{O}\right), 68.50(\mathrm{C} 5), 77.41(\mathrm{C} 2), 80.57$ (C3), 90.12 (C4), $112.93\left(\mathrm{CMe}_{2}\right), 113.76,126.17,126.89,159.33$ (Ar); 174.86 (C1); HRMS (TOF) $m / z$ calcd for $\mathrm{C}_{15} \mathrm{H}_{18} \mathrm{O}_{6} \mathrm{Na}^{+}[\mathrm{M}+\mathrm{Na}]^{+} 317.0996$, found 317.0982 .

\section{2,3-O-Isopropylidene-5-O-mesyl-4-C-methyl-D-ribono-1,4-lactone}

(85a).

Treatment of $75 \mathrm{a}(20 \mathrm{mg}, 0.09 \mathrm{mmol})$ with $\mathrm{MsCl}$ by Procedure A (column 
chromatography; hexane/EtOAc, 6:4) gave 76a (17 mg, 63\%): ${ }^{1} \mathrm{H}$ NMR $\left(\mathrm{CDCl}_{3}\right) \delta-1.32$ (s, 3H, C1a), 1.35 (s, 3H, Me), 1.42 (s, 3H, Me), 2.99 (s, 3H, Ms), 4.15 (d, $J=11.0 \mathrm{~Hz}$, 1H, H5), 4.25 (d, $\left.J=10.9 \mathrm{~Hz}, 1 \mathrm{H}, \mathrm{H} 5^{\prime}\right), 4.60$ (d, $\left.J=5.7 \mathrm{~Hz}, 1 \mathrm{H}, \mathrm{H} 2\right), 4.85$ (d, $J=5.7$ $\mathrm{Hz}, 1 \mathrm{H}, \mathrm{H} 3)$.

2,3-O-Isopropylidene-4- $C$-hexyl-5, $O$-mesyl-D-ribono-1,4-lactone (85b). Treatment of $\mathbf{8 4 \mathbf { b }}(22 \mathrm{mg}, 0.08 \mathrm{mmol})$ with $\mathrm{MsCl}$ by Procedure A (column chromatography; hexane/EtOAc, 7:3) gave 85b (14 mg, 50\%): ${ }^{1} \mathrm{H} \mathrm{NMR}\left(\mathrm{CDCl}_{3}\right) \delta 0.80(\mathrm{t}, J=6.6 \mathrm{~Hz}, 3 \mathrm{H}$, C6a), 1.20-1.28 (m, 8H, C2a-C5a), 1.33 (s, 3H, Me), 1.41 ( s, 3H, Me), 1.50-1.60 (m, 2H, C1a), 2.99 (s, 3H, Ms), 4.20 (d, $J=11.0 \mathrm{~Hz}, 1 \mathrm{H}, \mathrm{H} 5), 4.32$ (d, $J=11.0 \mathrm{~Hz}, 1 \mathrm{H}, \mathrm{H} 5$ '), $4.60(\mathrm{~d}, J=5.7 \mathrm{~Hz}, 1 \mathrm{H}, \mathrm{H} 2), 4.88(\mathrm{~d}, J=5.7 \mathrm{~Hz}, 1 \mathrm{H}, \mathrm{H} 3) ;{ }^{13} \mathrm{C} \mathrm{NMR}\left(\mathrm{CDCl}_{3}\right) \delta 14.03$ $\left(\mathrm{CH}_{3}, \mathrm{C} 6 \mathrm{a}\right), 22.46$ \& $23.37\left(\mathrm{CMe}_{2}\right), 25.78,26.69,29.55,31.38$ (C2a-C5a), 31.45 (C1a), 45.20 (Ms), 71.80 (C5), 77.91 (C3), 85.77 (C2), 113.79 (C4), $117.85\left(\mathrm{CMe}_{2}\right), 173.21$ (C1).

2,3-O-Isopropylidene-5-O-mesyl-4- $C$-octyl-D-ribono-1,4-lactone (85c). Treatment of $84 \mathrm{c}(32 \mathrm{mg}, 0.1 \mathrm{mmol}$ ) with $\mathrm{MsCl}$ by Procedure A (column chromatography; hexane/EtOAc, 6:4) gave 85c (14 mg, 50\%): ${ }^{1} \mathrm{H}$ NMR $\left(\mathrm{CDCl}_{3}\right) \delta 0.80(\mathrm{t}, J=6.6 \mathrm{~Hz}, \mathrm{Me}$, C8a), 1.20-1.28 (m, 12H, C2a-C7a), 1.35 (s, 3H, Me), 1.41 (s, 3H, Me), 1.50-1.60 (m, 2H, C1a), 3.0 (s, 3H, Ms), 4.20 (d, $J=10.9 \mathrm{~Hz}, 1 \mathrm{H}, \mathrm{H} 5), 4.32$ (d, $\left.J=10.9 \mathrm{~Hz}, 1 \mathrm{H}, \mathrm{H} 5^{\prime}\right)$, $4.60(\mathrm{~d}, J=5.6 \mathrm{~Hz}, 1 \mathrm{H}, \mathrm{H} 2), 4.84(\mathrm{~d}, J=5.6 \mathrm{~Hz}, 1 \mathrm{H}, \mathrm{H} 3) ;{ }^{13} \mathrm{C} \mathrm{NMR}\left(\mathrm{CDCl}_{3}\right) \delta 14.08$ $\left(\mathrm{CH}_{3}, \mathrm{C} 8 \mathrm{a}\right), 22.63$ \& $23.46\left(\mathrm{CMe}_{2}\right), 25.81,26.74,29.12,29.24,30.04,30.52$ (C2a-C7a), 31.14 (C1a), 44.50 (Ms), 71.76 (C5), 77.31 (C3), 78.91 (C2), 113.76 (C4), 117.92 $(\mathrm{CMe}), 171.01(\mathrm{C} 1)$. 


\section{2,3-O-Isopropylidene-5, $O$-mesyl-4- $C$-4-methoxyphenyl-D-ribono-1,4-lactone}

(85e). Treatment of 84e (24 mg, $0.08 \mathrm{mmol}$ ) with $\mathrm{MsCl}$ by Procedure A (column chromatography; hexane/EtOAc, 6:4) gave 85e (25 mg, 83\%): ${ }^{1} \mathrm{H}$ NMR $\left(\mathrm{CDCl}_{3}\right) \delta 1.35$ (s, 3H, Me), $1.41(\mathrm{~s}, 3 \mathrm{H}, \mathrm{Me}), 3.0(\mathrm{~s}, 3 \mathrm{H}, \mathrm{Ms}), 3.80\left(\mathrm{~s}, 3 \mathrm{H}, \mathrm{CH}_{3} \mathrm{O}\right), 4.20(\mathrm{~d}, J=11.2 \mathrm{~Hz}$, 1H, H5), 4.55 (d, $\left.J=11.2 \mathrm{~Hz}, 1 \mathrm{H}, \mathrm{H} 5^{\prime}\right), 5.01$ (d, $\left.J=5.5 \mathrm{~Hz}, 1 \mathrm{H}, \mathrm{H} 2\right), 5.15$ (d, $J=5.5 \mathrm{~Hz}$, $1 \mathrm{H}, \mathrm{H} 3), 6.82(\mathrm{~d}, J=8.8 \mathrm{~Hz}, 2 \mathrm{H}, \mathrm{Ar}), 7.12(\mathrm{~d}, J=9.0 \mathrm{~Hz}, 2 \mathrm{H}, \mathrm{Ar}) ;{ }^{13} \mathrm{C} \mathrm{NMR}\left(\mathrm{CDCl}_{3}\right) \delta$ $25.90 \& 26.58\left(\mathrm{CMe}_{2}\right), 44.10(\mathrm{Ms}), 55.33\left(\mathrm{CH}_{3} \mathrm{O}\right), 73.26(\mathrm{C} 5), 77.35(\mathrm{C} 2), 79.71(\mathrm{C} 3)$, 87.04 (C4), $113.79\left(C \mathrm{Me}_{2}\right), 114.10,124.91,127.00,159.95$ (Ar); 173.01 (C1).

2,3-O-Isopropylidene-4- $\boldsymbol{C}$-hexyl-5- $\boldsymbol{O}$-trityl- $\boldsymbol{D}$-ribofuranose $\quad$ (86b). $\quad \mathrm{LiEt}_{3} \mathrm{BH}$ (1M/THF, $0.18 \mathrm{~mL}, 0.18 \mathrm{mmol})$ was added dropwise to a solution of $\mathbf{8 4 \mathbf { b }}(37 \mathrm{mg}, 0.07$ mmol) in $\mathrm{CH}_{2} \mathrm{Cl}_{2}(0.5 \mathrm{~mL})$. The mixture was stirred for 30 min at $0{ }^{\circ} \mathrm{C}$ (ice-bath) under $\mathrm{N}_{2}$ atmosphere. The reaction was quenched with $\mathrm{MeOH}$, the volatiles were then evaporated. The residue was partitioned between $\mathrm{CH}_{2} \mathrm{Cl}_{2}$ and $\mathrm{N}_{\mathrm{a}} \mathrm{HCO}_{3}$, washed with brine and dried with anhydrous $\mathrm{MgSO}_{4}$. The resulting oil was column chromatographed (75:15, hexane: ethyl acetate) to give a mixture of anomers $\alpha / \beta \mathbf{8 6 b}(\alpha: \beta ; 1: 3 ; 20 \mathrm{mg}$, 54\%): The major anomer had: ${ }^{1} \mathrm{H}$ NMR $\left(\mathrm{CDCl}_{3}\right) \delta 0.80(\mathrm{t}, J=6.6 \mathrm{~Hz}, 3 \mathrm{H}, \mathrm{C} 6 \mathrm{a}), 1.20$ 1.28 (m, 8H, C2a-C5a), 1.33 (s, 3H, Me), 1.41 (s, 3H, Me), 1.50-1.60 (m, 2H, C1a), 3.16 (d, $J=10.08 \mathrm{~Hz}, 1 \mathrm{H}, \mathrm{H} 5), 3.32(\mathrm{~d}, J=10.08 \mathrm{~Hz}, 1 \mathrm{H}, \mathrm{H} 5$ '), 3.74 (d, $J=8.8 \mathrm{~Hz}, \mathrm{OH}), 4.50$ $(\mathrm{d}, J=6.0 \mathrm{~Hz}, 1 \mathrm{H}, \mathrm{H} 3), 4.75(\mathrm{~d}, J=6.0 \mathrm{~Hz}, 1 \mathrm{H}, \mathrm{H} 2), 5.15$ (d, $J=8.4 \mathrm{~Hz}, 1 \mathrm{H}, \mathrm{H} 1) .7 .25-$ $7.38(\mathrm{~m}, 15 \mathrm{H}, \mathrm{Ar})$; the minor anomer had: ${ }^{1} \mathrm{H} \mathrm{NMR}\left(\mathrm{CDCl}_{3}\right) \delta 0.80(\mathrm{t}, J=6.6 \mathrm{~Hz}, 3 \mathrm{H}$, C6a), 1.20-1.28 (m, 8H, C2a-C5a), 1.33 (s, 3H, Me), 1.41 (s, 3H, Me), 1.50-1.60 (m, 2H, C1a), $2.94(\mathrm{~d}, J=9.9 \mathrm{~Hz}, 1 \mathrm{H}, \mathrm{H} 5), 3.25$ (d, $J=9.9 \mathrm{~Hz}, 1 \mathrm{H}, \mathrm{H} 5$ '), 3.86 (d, $J=11.5 \mathrm{~Hz}$ $\mathrm{OH}), 4.20(\mathrm{~d}, J=6.1 \mathrm{~Hz}, 1 \mathrm{H}, \mathrm{H} 3), 4.62(\mathrm{dd}, J=4.2,6.1 \mathrm{~Hz}, 1 \mathrm{H}, \mathrm{H} 2), 5.61(\mathrm{dd}, J=4.2$, 
$11.5 \mathrm{~Hz}, 1 \mathrm{H}, \mathrm{H} 1), 7.25-7.38$ (m, $15 \mathrm{H}, \mathrm{Ar}) . \alpha / \beta$-anomers mixture had: ${ }^{13} \mathrm{C} \mathrm{NMR}\left(\mathrm{CDCl}_{3}\right)$ $\delta$ 14.01, 23.61 (C6a, $\alpha \& \beta$ anomers), 23.94 (C6a), $24.57 \& 24.98$ (CMe 2$), 25.99,26.22$, 29.65, 31.51 (C2a-C5a), 31.83 (C1a), $67.33 \& 68.18$ (C5), $80.01 \& 82.78$ (C2), $83.09 \&$ 83.82 (C3), $88.05 \& 88.12$ (C4), $96.55 \& 102.85(\mathrm{C} 1), 112.06 \& 112.32\left(\mathrm{CMe}_{2}\right), 126.56$, $127.30,127.67,142.09(\mathrm{Ar}), 139.0 \& 143.1(\mathrm{CO}), 156.08 \& 158.03(\mathrm{CO}), 174.81(\mathrm{C} 1)$.

2,3-O-Isopropylidene-4-C-octyl-D-ribofuranose (86c). Treatment of $84 \mathrm{c}(11 \mathrm{mg}$, $0.03 \mathrm{mmol}$ ) with $\mathrm{LiEt}_{3} \mathrm{BH}$, as described for $\mathbf{8 6 \mathbf { b }}$ gave a mixture of $\alpha / \beta$-anomers $86 \mathbf{c}(\alpha: \beta$; 1:1; $7 \mathrm{mg}, 63 \%){ }^{1} \mathrm{H}$ NMR $\left(\mathrm{CDCl}_{3}\right) \delta$ 0.80-0.82 (m, 2 x C8a), 1.20-1.28 (m, 24H, 6 × 2 x $\left.\mathrm{CH}_{2}, \mathrm{C} 2 \mathrm{a}-\mathrm{C} 7 \mathrm{a}\right), 1.33$ (s, 6H, 2 x Me), 1.41 (s, 6H, 2 x Me), 1.50-1.60 (m, 4H, 2 x C1a), 3.55 (d, $J=11.8 \mathrm{~Hz}, 2 \mathrm{H}, \mathrm{H} 5), 3.94$ (d, $J=11.8 \mathrm{~Hz}, 2 \mathrm{H}, \mathrm{H} 5$ '), 3.96 (d, $J=7.9 \mathrm{~Hz}, 1 \mathrm{H}$, $\mathrm{H} 3, \alpha$-anomer), $4.10(\mathrm{dd}, J=4.2,7.9 \mathrm{~Hz}, 1 \mathrm{H}, \mathrm{H} 2, \alpha$-anomer), $4.28(\mathrm{~m}, 1 \mathrm{H}, \mathrm{H} 2, \beta$ anomer), 4.41 (d, $J=5.0 \mathrm{~Hz}, 1 \mathrm{H}, \mathrm{H} 3, \beta$-anomer), 4.81 (s, $1 \mathrm{H}, \mathrm{H} 1, \beta$-anomer), 5.09 (d, $J=$ 4.1 Hz, 1H, H1, $\alpha$-anomer).

\section{$S$-(2,3-O-Isopropylidene-4-C-hexyl-D-ribono-1,4-lactone-5-yl)- $N$-tert-} butoxycarbonyl-L-homocysteine tert-butyl ester (89b). Procedure G. LDA (2M/THF and heptanes, $40 \mu 1,0.08 \mathrm{mmol}$ ) was added slowly to a stirred solution of protected Lhomocysteine 49 (27 mg, $0.093 \mathrm{mmol}$ ) (prepared by Procedure B, step a) in anhydrous DMF $1.5 \mathrm{ml}$ under $\mathrm{Ar}$ atmosphere at $0{ }^{\circ} \mathrm{C}$ (ice bath). After $30 \mathrm{~min}$, solution $\mathbf{8 5 b}(11 \mathrm{mg}$, $0.031 \mathrm{mmol})$ in $\operatorname{DMF}(2 \mathrm{~mL})$ was added by a syringe and the mixture was left stirring for 15 min at $0{ }^{\circ} \mathrm{C}$ then at room temperature for 24 hours. The TLC shows 5 different spots. The significant ones were the ones for disulfide $\left(R_{f}=0.55\right)$, the thiol $\left(R_{f}=0.65\right)$, the desired product at $R_{f}=0.50$ and a byproduct at $R_{f}=0.30$. The reaction was quenched with $\mathrm{NH}_{4} \mathrm{Cl}$ and volatiles were evaporated on high vaccum. The residue was partitioned 
between ethyl acetate and $\mathrm{NaHCO}_{3}$, washed with brine and dried with anhydrous $\mathrm{MgSO}_{4}$. The resulting oil was column chromatographed (8:2, hexane: ethyl acetate) to give $\mathbf{8 9 b}$ (18 mg, 65\%): ${ }^{1} \mathrm{H}$ NMR $\left(\mathrm{CDCl}_{3}\right) \delta 0.80(\mathrm{t}, J=6.6 \mathrm{~Hz}, 3 \mathrm{H}, \mathrm{C} 6 \mathrm{a}), 1.20-1.28\left(\mathrm{~m}, 2 \times 4 \mathrm{CH}_{2}\right.$, C2a-C5a), 1.31 (s, 3H, Me), $1.39 \& 1.41$ (2 x s, 18H), 1.42 (s, 3H, Me), 1.50-1.60 (m, 2H, C1a), 2.99 (s, 3H), 1.80 (m, 1H, H7), 1.90 (m, 1H, H7'), 2.50 (m, 2H, H6 and H6'), 2.72 (d, $J=14.68 \mathrm{~Hz}, 1 \mathrm{H}, \mathrm{H} 5), 2.80$ (d, $J=14.72 \mathrm{~Hz}, 1 \mathrm{H}, \mathrm{H} 5$ '), 4.20-4.25 (m, 1H, C8), 4.40 $(\mathrm{d}, J=5.92 \mathrm{~Hz}, 1 \mathrm{H}, \mathrm{H} 3), 5.00(\mathrm{~d}, 1 \mathrm{H}, \mathrm{NH}), 5.10(\mathrm{~d}, J=5.88 \mathrm{~Hz}, 1 \mathrm{H}, \mathrm{H} 2) .{ }^{13} \mathrm{C}$ NMR $\left(\mathrm{CDCl}_{3}\right) \delta 14.01$ (C6a), $22.5 \& 22.7\left(\mathrm{CMe}_{2}\right), 23.45,25.66,26.56,30.67$ (C2a-C5a), 28.08 (t-Bu), 28.32 (t-Bu), 34.34 (C1a), 39.86 (C5), 77.0 (C2), 77.20 (C3), 80.59 (CO), 82.41 (CO), 88.98 (C4), $113.30\left(\mathrm{CMe}_{2}\right), 139.0(\mathrm{CO}), 156$ (CO), 174 (C1). HRMS calcd for $\mathrm{C}_{27} \mathrm{H}_{48} \mathrm{NO}_{8} \mathrm{~S}^{+}[\mathrm{M}+\mathrm{H}]^{+}$546.3095, found 546.3104.

\section{$S$-(2,3-O-Isopropylidene-4-C-octyl-D-ribono-1,4-lactone-5-yl)- $N$-tert-}

butoxycarbonyl-L-homocysteine tert-butyl ester (89c). Treatment of $85 \mathrm{c}(24 \mathrm{mg}, 0.063$ mmol) with homocysteinate lithium salt as described by procedure $\mathrm{G}$ gave a mixture of Hcy and 89c that couldn't be separated on column since they have the same $R_{f}=0.55$ (5:1, $60 \mathrm{mg}):{ }^{1} \mathrm{H} \mathrm{NMR}\left(\mathrm{CDCl}_{3}\right) \delta 0.80(\mathrm{t}, J=6.6 \mathrm{~Hz}, \mathrm{Me}, \mathrm{C} 8 \mathrm{a}), 1.20-1.25$ (m, 12H, C2aC7a), 1.21 (s, 3H, Me), 1.40 (s, 3H, Me), $1.39 \& 1.41$ (2 x s, 90H), 1.50-1.60 (m, 2H, C1a), 1.85-1.89 (m, 6H, H7), 1.9-2.0 (m, 6H, H7'), 2.68-2.71 (m, 10H, H6 and H6'), 2.80$2.83(\mathrm{~m}, \mathrm{H} 5, \mathrm{H} 5$ ', 2H), 4.20-4.26 (m, C8, 9H), 4.40 (d, $J=5.92 \mathrm{~Hz}, 1 \mathrm{H}, \mathrm{H} 3), 5.10$ (d, 1H, $\mathrm{NH}), 5.15(\mathrm{~d}, J=5.88 \mathrm{~Hz}, 1 \mathrm{H}, \mathrm{H} 2)$.

$S$-(2,3-O-Isopropylidene-4- $C$-4-methoxyphenyl-D-ribono-1,4-lactone-5-yl)- $N$-tertbutoxycarbonyl-L-homocysteine tert-butyl ester (89e). Treatment of 85e (22 mg, 0.07 mmol) with homocysteinate lithium salt as described by procedure $G$ gave a mixture of 
Hcy and 89e (20 mg, 48\%): ${ }^{1} \mathrm{H}$ NMR $\left(\mathrm{CDCl}_{3}\right) \delta 1.35$ (s, 3H, Me), 1.41 (s, 3H, Me), 1.39 \&1.41 (2x s, 18H), 1.80 (m, 1H, H7), 1.90 (m, 1H, H7'), 2.50 (m, 2H, H6 and H6'), 2.85 (d, $J=14.8 \mathrm{~Hz}, 1 \mathrm{H}, \mathrm{H} 5), 3.20$ (d, $\left.J=15.1 \mathrm{~Hz}, 1 \mathrm{H}, \mathrm{H} 5^{\prime}\right), 3.80$ (s, 3H, $\left.\mathrm{CH}_{3} \mathrm{O}\right), 4.20-4.25$ (m, 1H, C8), $4.80(\mathrm{~d}, J=5.8 \mathrm{~Hz}, 1 \mathrm{H}, \mathrm{H} 3), 5.01$ (d, $, J=8.1 \mathrm{~Hz} 1 \mathrm{H}, \mathrm{NH}), 5.30$ ( d, $J=5.8$ Hz, 1H, H2), 6.82 (d, $J=8.8 \mathrm{~Hz}, 2 \mathrm{H}, \mathrm{Ar}), 7.12$ (d, $J=9.0 \mathrm{~Hz}, 2 \mathrm{H}, \mathrm{Ar}$ ); HRMS calcd for $\mathrm{C}_{28} \mathrm{H}_{41} \mathrm{NO}_{9} \mathrm{SNa}^{+}[\mathrm{M}+\mathrm{Na}]^{+} 590.2394$, found 590.2378 .

$S$-(4-C-Hexyl-D-ribono-1,4-lactone-5-yl)-L-homocysteine (90b). Procedure H. Procedure H. Step a. Compound 89b (18 $\mathrm{mg}, 0.03 \mathrm{mmol})$ was stirred in TFA (2 mL) at $0{ }^{\circ} \mathrm{C}$ for $1 \mathrm{~h}$ then placed in ambient temperature for $3 \mathrm{~h}$. Step $b . \mathrm{H}_{2} \mathrm{O}(0.1 \mathrm{~mL})$ was added to the reaction mixture from Step $a$ and stirring was continued for $1 \mathrm{~h}$ at ambient temperature. Volatiles were evaporated and the residue was coevaporated with acetonitrile $(0.1 \mathrm{~mL})$ to give $90 \mathrm{~b}(7 \mathrm{mg}, 60 \%):{ }^{1} \mathrm{H} \mathrm{NMR}\left(\mathrm{CDCl}_{3}\right) \delta 0.82(\mathrm{t}, J=6.6 \mathrm{~Hz}$, Me, C6a), 1.20-1.28 (m, 12H, C2a-C5a), 1.45-1.50 (m, 2H, C1a), 1.87-2.00 (m, 1H, H7), 2.05-2.12 (m, 1H, H7'), 2.45-2.55 (m, 2H, H6 \& H6'), 2.82 (d, $J=13.6 \mathrm{~Hz}, 1 \mathrm{H}, \mathrm{H} 5), 2.87$ $\left(\mathrm{d}, J=13.6 \mathrm{~Hz}, 1 \mathrm{H}, \mathrm{H} 5^{\prime}\right), 4.14(\mathrm{~d}, J=5.4 \mathrm{~Hz}, 1 \mathrm{H}, \mathrm{H} 2), 4.72(\mathrm{~d}, J=5.4 \mathrm{~Hz}, 1 \mathrm{H}, \mathrm{H} 3) ;{ }^{13} \mathrm{C}$ NMR $\left(\mathrm{CDCl}_{3}\right) \delta 15.01$ (C6a), 23.20, 23.56, 23.90, 29.20 (C2a-C5a), 32.10 (C1a), 63.25 (C5), 72.55 (C2), 78.50 (C3), 88.50 (C4), 141.50 (C1). HRMS calcd for $\mathrm{C}_{15} \mathrm{H}_{27} \mathrm{NO}_{6} \mathrm{~S}^{+}$ $[\mathrm{M}+\mathrm{H}]^{+} 350.163$, found 350.182 and $[\mathrm{M}+\mathrm{Na}]^{+} 372.145$, found 372.161 .

$S$-(4-C-Octyl-D-ribono-1,4-lactone-5-yl)-L-homocysteine (90c). Treatment of the crude 89c contaminated by the protected homocysteine as described above for 89c (1:5, $60 \mathrm{mg}, 0.02 \mathrm{mmol})$ in TFA $(2 \mathrm{~mL})$ by Procedure $\mathrm{H}$ gave an oily residue that was partitioned between water and chloroform. The aqueous layer was evaporated. The residue $(20 \mathrm{mg})$ was divided into two portions. Each portion was separately purified on 
Sep-Pak column (classic C18) as follow. The portion of crude 90c was dissolved in water/ACN $(2.5 \mathrm{~mL}, 19: 1, \mathrm{v} / \mathrm{v})$ and was injected into the Sepak column. The column was eluted with $5 \mathrm{~mL}$ of water, a second portion of $5 \mathrm{~mL}$ of water and $5 \mathrm{~mL}$ of ethanol. The first water eluent contained mainly Hcy (TLC and ${ }^{1} \mathrm{H}$ NMR) while the ethanol eluent was evaporated to give 90c (5 mg, 76\%): ${ }^{1} \mathrm{H}$ NMR $\left(\mathrm{CDCl}_{3}\right) \delta 0.82(\mathrm{t}, J=6.6 \mathrm{~Hz}, \mathrm{Me}, \mathrm{C} 8 \mathrm{a})$, 1.20-1.28 (m, 12H, C2a-C7a), 1.50-1.60 (m, 2H, C1a), 1.90-2.00 (m, 1H, H7), 2.05-2.12 (m, 1H, H7'), 2.55-2.65 (m, 2H, H6 \& H6'), 2.80 (d, $J=13.8 \mathrm{~Hz}, 1 \mathrm{H}, \mathrm{H} 5), 2.87$ (d, $J=$ $\left.13.9 \mathrm{~Hz}, 1 \mathrm{H}, \mathrm{H} 5^{\prime}\right), 4.14$ (d, $\left.J=5.4 \mathrm{~Hz}, 1 \mathrm{H}, \mathrm{H} 2\right), 4.72$ (d, $\left.J=5.4 \mathrm{~Hz}, 1 \mathrm{H}, \mathrm{H} 3\right) ;{ }^{13} \mathrm{C} \mathrm{NMR}$ $\left(\mathrm{CDCl}_{3}\right) \delta 15.01$ (C8a), 23.00, 23.50, 23.85, 29.00, 30.67, 30.51 (C2a-C7a), 32.07 (C1a), 60.50 (C6), 61.20 (C7), 62.25 (C5), 71.54 (C2), 77.20 (C3), 84.59 (C4), 141.50 (C1). HRMS calcd for $\mathrm{C}_{17} \mathrm{H}_{31} \mathrm{NO}_{6} \mathrm{~S}^{+}[\mathrm{M}+\mathrm{H}]^{+} 378.1945$, found 378.1964 and $[\mathrm{M}+\mathrm{Na}]^{+}$ 400.1764, found 400.1783.

$S$-(4-C-4-Methoxyphenyl-D-ribono-1,4-lactone-5-yl)-L-homocysteine

(90e). Treatment of 89e $(6.2 \mathrm{mg}, 0.01 \mathrm{mmol})$ with in TFA $(1 \mathrm{~mL})$ as described by procedure $\mathrm{H}$ gave 90e (3 mg, 75\%): ${ }^{1} \mathrm{H}$ NMR $\left(\mathrm{CDCl}_{3}\right) \delta{ }^{1} \mathrm{H}$ NMR $\left(\mathrm{CDCl}_{3}\right) \delta 3.80\left(\mathrm{~s}, 3 \mathrm{H}, \mathrm{CH}_{3} \mathrm{O}\right), 1.80$ (m, 1H, H7), 1.90 (m, 1H, H7'), 2.50 (m, 2H, H6 and H6'), 2.85 (d, $J=14.8 \mathrm{~Hz}, 1 \mathrm{H}, \mathrm{H}$ ), 3.20 (d, $\left.J=15.1 \mathrm{~Hz}, 1 \mathrm{H}, \mathrm{H} 5^{\prime}\right), 4.20$ (d, $\left.J=5.8 \mathrm{~Hz}, 1 \mathrm{H}, \mathrm{H} 2\right), 4.20-4.25$ (m, 1H, C8), 4.70 $(\mathrm{d}, J=5.8 \mathrm{~Hz}, 1 \mathrm{H}, \mathrm{H} 3), 6.82(\mathrm{~d}, J=8.8 \mathrm{~Hz}, 2 \mathrm{H}, \mathrm{Ar}), 7.12(\mathrm{~d}, J=9.0 \mathrm{~Hz}, 2 \mathrm{H}, \mathrm{Ar}) ;{ }^{13} \mathrm{C}$ NMR $\left(\mathrm{CDCl}_{3}\right) \delta 15.01(\mathrm{C} 8 \mathrm{a}), 55.33\left(\mathrm{CH}_{3} \mathrm{O}\right), 63.20(\mathrm{C} 5), 74.40$ (C2), $78.20(\mathrm{C} 3), 85.40$ (C4), 117.20, 125.81, 127.00, 162.28 (Ar), 143.50 (C1); HRMS calcd for $\mathrm{C}_{16} \mathrm{H}_{21} \mathrm{NO}_{7} \mathrm{~S}^{+}$ $[\mathrm{M}+\mathrm{Na}]^{+}$394.0931, found 393.2894.

2,3-O-Isopropylidene-5-[(tert-butoxycarbonyl)-L-homocysteine tert-butyl ester]4-C-hexyl-D-ribofuranose (91b). Procedure I. LiEt $_{3} \mathrm{BH}(1 \mathrm{M} / \mathrm{THF}, 0.05 \mathrm{~mL}, 0.05$ 
mmol) was added dropwise to a solution of $89 \mathbf{b}(5 \mathrm{mg}, 0.009 \mathrm{mmol})$ in $\mathrm{CH}_{2} \mathrm{Cl}_{2}(0.5 \mathrm{~mL})$. The mixture was stirred for $30 \mathrm{~min}$ at $0{ }^{\circ} \mathrm{C}$ (ice-bath) under $\mathrm{N}_{2}$ atmosphere. The reaction was quenched with $\mathrm{MeOH}$, the volatiles were then evaporated. The residue was partitioned between $\mathrm{CH}_{2} \mathrm{Cl}_{2}$ and $\mathrm{N}_{\mathrm{a}} \mathrm{HCO}_{3}$, washed with brine and dried with anhydrous $\mathrm{MgSO}_{4}$. The resulting oil was column chromatographed (80:20, hexane: ethyl acetate) to give a 91b mixture of anomers $\alpha / \beta$ ( $\beta$ major product, $4.5 \mathrm{mg}, 90 \%):{ }^{1} \mathrm{H} \mathrm{NMR}\left(\mathrm{CDCl}_{3}\right) \delta$ $0.80(\mathrm{t}, J=6.6 \mathrm{~Hz}, \mathrm{Me}, \mathrm{C} 8 \mathrm{a}), 1.2-1.28(\mathrm{~m}, 8 \mathrm{H}, \mathrm{C} 2 \mathrm{a}-\mathrm{C} 5 \mathrm{a}), 1.35-1.41(2 \mathrm{x} \mathrm{s}, 18 \mathrm{H}), 1.35$ (s, $6 \mathrm{H}), 1.50-1.60$ (m, 2H, C1a), 1.9-2.0 (m, 2H, H7, H7'), 2.48-2.58 (m, 2H, H6, H6'), 2.60 (d, $J=12.8 \mathrm{~Hz}, 1 \mathrm{H}, \mathrm{H} 5), 2.94$ (d, $\left.J=12.6 \mathrm{~Hz}, 1 \mathrm{H}, \mathrm{H} 5^{\prime}\right), 4.19-4.21$ (m, 1H, H8), 4.44 (d, $J$ $=5.9 \mathrm{~Hz}, 1 \mathrm{H}, \mathrm{H} 3), 4.64(\mathrm{~d}, J=5.9 \mathrm{~Hz}, 1 \mathrm{H}, \mathrm{H} 2), 5.19-5.21(\mathrm{~m}, 1 \mathrm{H}, \mathrm{NH}), 5.35(\mathrm{~s}, 1 \mathrm{H}, \beta-$ H1).

2,3-O-Isopropylidene-5-[(tert-butoxycarbonyl)-L-homocysteine tert-butyl ester]4-C-4-methoxyphenyl-D-ribofuranose (91e). Treatment of 89e (6 mg, $0.01 \mathrm{mmol})$ with $\mathrm{LiEt}_{3} \mathrm{BH}(25 \mu \mathrm{L})$ following procedure I gave 92c $(4 \mathrm{mg}, 66 \%):{ }^{1} \mathrm{H} \mathrm{NMR}\left(\mathrm{CDCl}_{3}\right) \delta 1.35$ (s, 3H, Me), $1.41(\mathrm{~s}, 3 \mathrm{H}, \mathrm{Me}), 1.39 \& 1.41(2 \mathrm{x} \mathrm{s}, 18 \mathrm{H}), 1.80(\mathrm{~m}, 1 \mathrm{H}, \mathrm{H} 7), 1.90(\mathrm{~m}, 1 \mathrm{H}$, H7'), 2.50 (m, 2H, H6 and H6'), 3.01 (d, $J=14.8 \mathrm{~Hz}, 1 \mathrm{H}, \mathrm{H} 5), 3.20$ (d, $J=15.1 \mathrm{~Hz}, 1 \mathrm{H}$, H5'), $3.60(\mathrm{~d}, J=5.8 \mathrm{~Hz}, 1 \mathrm{H}, \mathrm{H} 3), 3.80\left(\mathrm{~s}, 3 \mathrm{H}, \mathrm{CH}_{3} \mathrm{O}\right), 4.01$ ("t", $\left.J=5.8 \mathrm{~Hz}, 1 \mathrm{H}, \mathrm{H} 2\right)$, 4.20-4.25 (m, 1H, C8), $5.01(\mathrm{~d}, J=8.1 \mathrm{~Hz} 1 \mathrm{H}, \mathrm{NH}), 5.60$ (s, H1, 1H, major isomer 99\%), $5.80(\mathrm{~d}, 1 \mathrm{H}$, minor isomer), $6.82(\mathrm{~d}, J=8.8 \mathrm{~Hz}, 2 \mathrm{H}, \mathrm{Ar}), 7.12(\mathrm{~d}, J=9.0 \mathrm{~Hz}, 2 \mathrm{H}$, Ar); HRMS calcd for $\mathrm{C}_{28} \mathrm{H}_{43} \mathrm{NO}_{9} \mathrm{~S}^{+}[\mathrm{M}+\mathrm{Na}]^{+}$592.2551, found 592.2492.

$\boldsymbol{S}$-(5-Deoxy-4- $\boldsymbol{C}$-hexyl-D-ribofuranos-5-yl)-L-homocysteine (92b). Treatment of 91b (4.5 mg, $0.01 \mathrm{mmol})$ with in TFA $(1 \mathrm{~mL})$ as described by procedure $\mathrm{H}$ gave $92 \mathbf{b}$ (2 $\mathrm{mg}, 75 \%):{ }^{1} \mathrm{H} \mathrm{NMR}\left(\mathrm{CDCl}_{3}\right) \delta 0.80(\mathrm{t}, J=6.6 \mathrm{~Hz}, \mathrm{Me}, \mathrm{C} 6 \mathrm{a}), 1.2-1.28(\mathrm{~m}, 8 \mathrm{H}, \mathrm{C} 2 \mathrm{a}-\mathrm{C} 5 \mathrm{a})$, 
1.50-1.60 (m, 2H, Cla), 1.9-2.0 (m, 2H, H7, H7'), 2.48-2.58 (m, 2H, H6, H6'), 2.60 (d, $J$ $=12.8 \mathrm{~Hz}, 1 \mathrm{H}, \mathrm{H} 5), 2.94\left(\mathrm{~d}, J=12.6 \mathrm{~Hz}, 1 \mathrm{H}, \mathrm{H} 5^{\prime}\right), 4.19-4.21(\mathrm{~m}, 1 \mathrm{H}, \mathrm{H} 8), 4.44$ (d, $J=$ $5.9 \mathrm{~Hz}, 1 \mathrm{H}, \mathrm{H} 3), 4.64$ ("t", $J=5.9 \mathrm{~Hz}, 1 \mathrm{H}, \mathrm{H} 2), 5.19-5.21$ (m, 1H, NH), 5.35 (s, 1H, $\alpha$ or $\beta-\mathrm{H} 1) ; \mathrm{MS}\left(\mathrm{ESI}^{-}\right) \mathrm{m} / z 350\left(\mathrm{MH}^{-}\right)$.

$S$-(5-Deoxy-4-C-octyl-D-ribofuranos-5-yl)-L-homocysteine (92c). Treatment of 90c $(6 \mathrm{mg}, 0.01 \mathrm{mmol})$ with $\mathrm{LiEt}_{3} \mathrm{BH}(0.03 \mathrm{~mL})$ following procedure I gave $92 \mathrm{c}(4 \mathrm{mg}$, 60\%): ${ }^{1} \mathrm{H} \mathrm{NMR}\left(\mathrm{CDCl}_{3}\right) \delta 0.80(\mathrm{t}, J=6.6 \mathrm{~Hz}, \mathrm{Me}, \mathrm{C} 8 \mathrm{a}), 1.2-1.32(\mathrm{~m}, 14 \mathrm{H}, \mathrm{C} 2 \mathrm{a}-\mathrm{C} 7 \mathrm{a})$, 1.50-1.60 (m, 2H, C1a), 1.9-2.0 (m, 2H, H7, H7'), 2.48-2.58 (m, 2H, H6, H6'), 2.79 (d, $J$ $\left.=12.8 \mathrm{~Hz}, 1 \mathrm{H}, \mathrm{H} 5), 2.90(\mathrm{~d}, J=12.6 \mathrm{~Hz}, 1 \mathrm{H}, \mathrm{H} 5)^{\prime}\right), 4.19-4.21(\mathrm{~m}, 1 \mathrm{H}, \mathrm{H} 8), 3.80(\mathrm{~d}, J=$ $5.9 \mathrm{~Hz}, 1 \mathrm{H}, \mathrm{H} 3), 4.50$ ("t", $J=5.9 \mathrm{~Hz}, 1 \mathrm{H}, \mathrm{H} 2), 5.19-5.21(\mathrm{~m}, 1 \mathrm{H}, \mathrm{NH}), 5.80$ (s, $0.5 \mathrm{H}, \beta-$ H1); $5.82(\mathrm{~s}, 0.5 \mathrm{H}, \alpha-\mathrm{H}) ;{ }^{13} \mathrm{C}$ NMR $\delta 15.01$ (C8a), 23.00, 23.50, 23.85, 29.00, 30.67, 30.51 (C2a-C7a), 32.07 (C1a), 40.50 (C6), 41.50 (C7), 41.99 (C5), 49.51 (C8), 62.77 (C3), 72.09 (C2), $87.16(\mathrm{C} 4), 99.90(\mathrm{C} 1), 174.50$ (CO); HRMS calcd for $\mathrm{C}_{17} \mathrm{H}_{33} \mathrm{NO}_{6} \mathrm{~S}^{+}$ $[\mathrm{M}+\mathrm{Na}]^{+}$396.2283, found 396.1862 .

\section{$S$-(5-Deoxy-4-C-4-methoxyphenyl-D-ribofuranos-5-yl)-L-homocysteine}

(92e). Treatment of 91e (4 mg, $0.01 \mathrm{mmol})$ with in TFA $(1 \mathrm{~mL})$ as described by procedure $\mathrm{H}$ gave 92e (2 mg, 75\%): ${ }^{1} \mathrm{H}$ NMR $\left(\mathrm{CDCl}_{3}\right) \delta 1.80(\mathrm{~m}, 1 \mathrm{H}, \mathrm{H} 7), 1.90(\mathrm{~m}, 1 \mathrm{H}, \mathrm{H} 7 \mathrm{\prime}), 2.50$ (m, 2H, H6 and H6'), 3.01 (d, $J=14.8 \mathrm{~Hz}, 1 \mathrm{H}, \mathrm{H} 5), 3.20$ (d, $\left.J=15.1 \mathrm{~Hz}, 1 \mathrm{H}, \mathrm{H} 5^{\prime}\right), 3.60$ (d, $J$ $=5.8 \mathrm{~Hz}, 1 \mathrm{H}, \mathrm{H} 3), 3.80\left(\mathrm{~s}, 3 \mathrm{H}, \mathrm{CH}_{3} \mathrm{O}\right), 4.01$ ("t", $\left.J=5.8 \mathrm{~Hz}, 1 \mathrm{H}, \mathrm{H} 2\right), 4.20-4.25(\mathrm{~m}, 1 \mathrm{H}$, C8), $5.60(\mathrm{~s}, \mathrm{H1}, 1 \mathrm{H}$, major isomer 99\%), $6.82(\mathrm{~d}, J=8.8 \mathrm{~Hz}, 2 \mathrm{H}, \mathrm{Ar}), 7.12$ (d, $J=9.0$ $\mathrm{Hz}, 2 \mathrm{H}, \mathrm{Ar}) ;{ }^{13} \mathrm{C} \mathrm{NMR}\left(\mathrm{CDCl}_{3}\right) \delta 15.01$ (C8a), $55.33\left(\mathrm{CH}_{3} \mathrm{O}\right), 63.20$ (C5), 64.40 (C2), 65.20 (C3), 85.40 (C4), 117.20, 125.81, 127.00, 162.28 (Ar), 173.50 (C1). 
5-O-Acetyl-1-deoxy-2,3-O-isopropylidene-4-thio-D-ribofuranose (94). DMAP (7 $\mathrm{mg}, 0.057 \mathrm{mmol})$ was added to a stirred solution of $93^{139}(117 \mathrm{mg}, 0.62 \mathrm{mmol})$ in $\mathrm{Ac}_{2} \mathrm{O}$ $(6 \mathrm{~mL})$ at ambient temperature. After $2.5 \mathrm{~h}, \mathrm{MeOH}(15 \mathrm{~mL})$ was added and resulting mixture was stirred for additional $1 \mathrm{~h}$ at $0^{\circ} \mathrm{C}$. The volatiles were evaporated to give the crude 94 (136 mg, 95\%), of sufficient purity to be directly used in next step: ${ }^{1} \mathrm{H}$ NMR $\delta$ 1.34 (s, 3H, Me), 1.54 (s, 3H, Me), 2.10 (s, 3H, Ac), 2.94 (dd, $J=1.2,13.0 \mathrm{~Hz}, 1 \mathrm{H}, \mathrm{H} 1)$ $3.12\left(\mathrm{dd}, J=4.7,13.0 \mathrm{~Hz}, 1 \mathrm{H}, \mathrm{H} 1^{\prime}\right) 3.49(\mathrm{ddd}, J=1.0,5.9,7.6 \mathrm{~Hz}, 1 \mathrm{H}, \mathrm{H} 4), 4.05$ (dd, $J=$ 8.4, 11.4 Hz, 1H, H5), 4.18 (dd, $\left.J=5.8,11.4 \mathrm{~Hz}, 1 \mathrm{H}, \mathrm{H}^{\prime}\right), 4.70$ (dd, $J=1.2,5.6 \mathrm{~Hz}, 1 \mathrm{H}$, H3), $4.94\left(' \mathrm{dt}^{\prime}, J=1.3,5.2 \mathrm{~Hz}, 1 \mathrm{H}, \mathrm{H} 2\right) ;{ }^{13} \mathrm{C} \mathrm{NMR} \delta 20.92(\mathrm{Ac}), 24.66\left(\mathrm{CMe}_{2}\right), 26.46$ $\left(\mathrm{CMe} e_{2}\right), 37.70(\mathrm{C} 1), 52.33(\mathrm{C} 4), 64.82$ (C5), 83.55 (C2), 85.72 (C3), $111.26\left(\mathrm{CMe}_{2}\right)$, $170.70(\mathrm{Ac})$.

\section{5-O-Acetyl-1-deoxy-2,3-O-isopropylidene-S-oxo-4-thio-D-ribofuranose}

$\left[\mathbf{9 5}(\boldsymbol{R} / \boldsymbol{S})_{\mathrm{S}}\right]$. A solution of MCPBA (138 $\mathrm{mg}, 0.56 \mathrm{mmol}, \sim 70 \%$ reagent $)$ in $\mathrm{CH}_{2} \mathrm{Cl}_{2}(3 \mathrm{~mL})$ was added dropwise to a solution of $94^{139}(136 \mathrm{mg}, 0.59 \mathrm{mmol})$ in $\mathrm{CH}_{2} \mathrm{Cl}_{2}(2 \mathrm{~mL})$ at -78 ${ }^{\circ} \mathrm{C}$, under Ar atmosphere. The resulting suspension was stirred for 30 min or until disappearance of 94 on $\mathrm{TLC}\left(14 \mathrm{~h},-78^{\circ} \mathrm{C} \rightarrow \mathrm{rt}\right)$. The reaction mixture was quenched with saturated $\mathrm{NaHCO}_{3} / \mathrm{H}_{2} \mathrm{O}$, and extracted with $\mathrm{CH}_{2} \mathrm{Cl}_{2}$. The combined organic layer was washed with brine, dried $\left(\mathrm{Na}_{2} \mathrm{SO}_{4}\right)$, and evaporated. The crude product was column chromatographed (50\% EtOAc/hexane) to give unchanged 94 (7 mg, 5\%) followed by $($ EtOAc $\rightarrow 10 \% \mathrm{MeOH} /$ EtOAc) $95(133 \mathrm{mg}, 91 \%)$ as a separable mixture (4:1) of two

diastereoisomers. Major isomer had: ${ }^{1} \mathrm{H}$ NMR $\delta 1.33$ (s, 3H, Me), 1.49 (s, 3H, Me), 2.10 (s, 3H, Ac), $3.23(\mathrm{dd}, J=4.1,14.4 \mathrm{~Hz}, 1 \mathrm{H}, \mathrm{H} 1), 3.34\left(\mathrm{dd}, J=6.4,14.4 \mathrm{~Hz}, 1 \mathrm{H}, \mathrm{H} 1^{\prime}\right) 3.36$ ('dt', $J=5.6,8.9 \mathrm{~Hz}, 1 \mathrm{H}, \mathrm{H} 4), 4.49$ (dd, $J=8.8,12.0 \mathrm{~Hz}, 1 \mathrm{H}, \mathrm{H} 5), 4.61$ (dd, $J=4.9,12.0$ 
$\left.\mathrm{Hz}, 1 \mathrm{H}, \mathrm{H} 55^{\prime}\right), 4.94(\mathrm{t}, J=6.1 \mathrm{~Hz}, 1 \mathrm{H}, \mathrm{H} 3), 5.22(\mathrm{dt}, J=4.2,6.3 \mathrm{~Hz}, 1 \mathrm{H}, \mathrm{H} 2) ;{ }^{13} \mathrm{C} \mathrm{NMR} \delta$ 20.80 ( $\mathrm{Ac}), 24.75\left(\mathrm{CMe}_{2}\right), 27.29\left(\mathrm{CMe}_{2}\right), 56.13$ (C1), 58.19 (C5), 63.93 (C4), 79.86 (C2), $82.75(\mathrm{C} 3), 113.47\left(\mathrm{CMe}_{2}\right), 170.29(\mathrm{Ac})$. Minor isomer had: ${ }^{1} \mathrm{H}$ NMR $\delta 1.37$ (s, 3H, Me), 1.61 (s, 3H, Me), 2.09 (s, 3H, Ac), 3.22 (dd, $J=6.0,14.8 \mathrm{~Hz}, 1 \mathrm{H}, \mathrm{H1}$ ), 3.42 ('td', $J=1.8$, $14.8 \mathrm{~Hz}, 1 \mathrm{H}, \mathrm{H1}$ ') 3.75-3.79 (m, 1H, H4), 4.35 (dd, $J=5.3,12.2 \mathrm{~Hz}, 1 \mathrm{H}, \mathrm{H} 5), 4.39$ (dd, $J$ $\left.=4.5,12.2 \mathrm{~Hz}, 1 \mathrm{H}, \mathrm{H} 5^{\prime}\right), 4.86(\mathrm{dd}, J=2.7,5.9 \mathrm{~Hz}, 1 \mathrm{H}, \mathrm{H} 3), 5.14(\mathrm{dt}, J=2.2,6.0 \mathrm{~Hz}, 1 \mathrm{H}$, H2); ${ }^{13} \mathrm{C}$ NMR $\delta 20.69(\mathrm{Ac}), 24.48\left(\mathrm{CMe}_{2}\right), 26.82\left(\mathrm{CMe}_{2}\right), 57.25$ (C1), 60.93 (C5), 71.40 (C4), 82.87 (C2), 84.45 (C3), $112.91\left(\mathrm{CMe}_{2}\right), 170.00$ (Ac); MS (ESI) m/z 249 (100, $\left.[\mathrm{MH}]^{+}\right)$.

\section{5-O-Acetyl-1-deoxy-1-fluoro-2,3- $O$-isopropylidene-4-thio- $\alpha / \beta$-D-ribofuranose}

(96), and 5-O-Acetyl-2,3- $O$-isopropylidene-4-thio- $\beta$-D-ribofuranose (99). Procedure

J. Deoxo-fluor (125 mg, $0.25 \mathrm{~mL}$ of $50 \%$ solution in THF, $0.57 \mathrm{mmol}$ ) was added to a stirred solution of sulfoxide $95(15.5 \mathrm{mg}, 0.11 \mathrm{mmol})$ in $\mathrm{CH}_{2} \mathrm{Cl}_{2}(0.5 \mathrm{~mL})$ containing $\mathrm{SbCl}_{3}(30 \mathrm{mg}, 0.13 \mathrm{mmol})$ under $\mathrm{Ar}$ atmosphere at ambient temperature. Reaction mixture was heated at $55{ }^{\circ} \mathrm{C}$ for $3 \mathrm{~h}$, and was quenched with saturated $\mathrm{NaHCO}_{3} / \mathrm{H}_{2} \mathrm{O}$. The resulting mixture was extracted with $\mathrm{CH}_{2} \mathrm{Cl}_{2}$ and the combined organic layer was washed with brine, dried $\left(\mathrm{Na}_{2} \mathrm{SO}_{4}\right)$, and evaporated. The crude product was column chromatographed ( $20 \rightarrow 25 \%$ EtOAc/hexane) to give 96 (9 mg, 58\%) as colorless oil of major $\beta$ anomer. ${ }^{1} \mathrm{H}$ NMR $\delta 1.33$ (s, 3H, Me), 1.48 (s, 3H, Me), 2.10 (s, 3H, Ac), 3.67 (ddd, $J=2.5,5.3,10.1 \mathrm{~Hz}, 1 \mathrm{H}, \mathrm{H} 4), 4.06$ ('t', $J=10.8 \mathrm{~Hz}, 1 \mathrm{H}, \mathrm{H} 5), 4.27$ (dd, $J=5.3$, $11.6 \mathrm{~Hz}, 1 \mathrm{H}, \mathrm{H} 5$ '), 4.94 (d, $J=5.4 \mathrm{~Hz}, 1 \mathrm{H}, \mathrm{H} 3), 5.03$ (dd, $J=5.4,9.5 \mathrm{~Hz}, 1 \mathrm{H}, \mathrm{H} 2), 5.97$ (d, $J=54.0 \mathrm{~Hz}, 1 \mathrm{H}, \mathrm{H} 1) ;{ }^{13} \mathrm{C}$ NMR $\delta 20.81(\mathrm{Ac}), 24.57\left(\mathrm{CMe}_{2}\right), 26.33\left(\mathrm{CMe}_{2}\right), 54.86$ (d, 
$J=1.8 \mathrm{~Hz}, \mathrm{C} 4), 65.82$ (C5), 84.81 (C3), 89.15 (d, $J=38.6 \mathrm{~Hz}, \mathrm{C} 2), 106.60$ (d, $J=218.3$

$\mathrm{Hz}, \mathrm{C} 1), 111.33\left(\mathrm{CMe}_{2}\right), 170.47(\mathrm{Ac}) ;{ }^{19} \mathrm{~F}$ NMR $\delta-140.85$ (ddd, $\left.J=2.3,9.5,54.0 \mathrm{~Hz}\right)$.

A further elution (25\% EtOAc/hexane) afforded an analytical sample of the minor $\alpha$ anomer of 96 (1.1 mg, 7\%): ${ }^{1} \mathrm{H}$ NMR $\delta 1.38$ (s, 3, Me), 1.56 (s, 3, Me), 2.10 (s, 3, Ac), 3.98-4.03 (m, 1H, H4), 4.19 (dd, $J=6.3,11.6 \mathrm{~Hz}, 1 \mathrm{H}, \mathrm{H} 5), 4.34$ (dd, $J=6.2,11.5 \mathrm{~Hz}$, 1H, H5'), 4.67 (dd, $J=3.5,6.7 \mathrm{~Hz}, 1 \mathrm{H}, \mathrm{H} 3$ ), 4.83 (ddd, $J=4.4,6.7,15.2 \mathrm{~Hz}, 1 \mathrm{H}, \mathrm{H} 2$ ), $5.81(\mathrm{dd}, J=4.4,56.7 \mathrm{~Hz}, 1 \mathrm{H}, \mathrm{H} 1) ;{ }^{13} \mathrm{C}$ NMR $\delta 20.72(\mathrm{Ac}), 25.82\left(\mathrm{~d}, J=1.4 \mathrm{~Hz}, \mathrm{CMe}_{2}\right.$ ), $25.94(\mathrm{~d}, J=2.3 \mathrm{~Hz}, \mathrm{CMe}$ ), 48.96 (C4), 64.42 (d, $J=2.1 \mathrm{~Hz}, \mathrm{C} 5), 83.21$ (C3), 85.06 (d, $J=19.8 \mathrm{~Hz}, \mathrm{C} 2), 98.02(\mathrm{~d}, J=231.5 \mathrm{~Hz}, \mathrm{C} 1), 115.27\left(\mathrm{CMe}_{2}\right), 170.49(\mathrm{Ac}) ;{ }^{19} \mathrm{~F}$ NMR $\delta$ $157.24(\mathrm{dd}, J=15.2,56.7 \mathrm{~Hz}) ; \mathrm{MS}(\mathrm{ESI}) \mathrm{m} / z 250\left(100, \mathrm{M}^{+}\right)$.

Additional elution (40\% EtOAc/hexane) resulted in the separation of the thiohemiacetal 99 ( $\beta$-anomer; $2.6 \mathrm{mg}, 17 \%) .{ }^{1} \mathrm{H}$ NMR $\delta 1.34$ (s, 3H, Me), 1.52 (s, 3H, Me), 2.13 (s, 3H, Ac), 2.50 (br. s, OH), 3.63-3.68 (m, 1H, H4), 4.17 (dd, $J=8.9,11.4 \mathrm{~Hz}$, 1H, H5), 4.41 (dd, $\left.J=5.8,11.4 \mathrm{~Hz}, 1 \mathrm{H}, \mathrm{H} 5^{\prime}\right), 4.87$ (d, $\left.J=5.4 \mathrm{~Hz}, 1 \mathrm{H}, \mathrm{H} 3\right), 4.92$ (d, $J=$ $5.4 \mathrm{~Hz}, 1 \mathrm{H}, \mathrm{H} 2), 5.37$ (br. s, $1 \mathrm{H}, \mathrm{H} 1) ;{ }^{13} \mathrm{C}$ NMR $\delta 20.90$ (Ac), $24.56\left(\mathrm{CMe}_{2}\right), 26.44$ (CMe 2$), 54.83$ (C4), 66.53 (C5), 85.78 (C3), 86.98 (C1), 90.47 (C2), $110.82\left(\mathrm{CMe}_{2}\right)$, $170.57(\mathrm{Ac})$.

Procedure K: Sulfide 94 (27.5 mg, $0.12 \mathrm{mmol})$ was treated with Deoxo-fluor (127 $\mathrm{mg}, 0.26 \mathrm{~mL}, 50 \%$ soln in THF, $0.59 \mathrm{mmol})$ and $\mathrm{SbCl}_{3}(30 \mathrm{mg}, 0.13 \mathrm{mmol})$ as described above (Procedure J, $4 \mathrm{~h}$ ). The crude product (spectrally identical to the crude sample obtained by Procedure J) was column chromatographed $(20 \rightarrow 25 \%$ EtOAc/hexane) to give major $\beta$ anomer of 96 (14.5 mg, 49\%) as colorless oil. 
1-Deoxy-1-fluoro-2,3-O-isopropylidene-4-thio- $\beta$-D-ribofuranose (97). Compound 96 ( $\beta$-anomer; $45 \mathrm{mg}, 0.18 \mathrm{mmol}$ ) was dissolved in saturated methanolic ammonia solution $(4 \mathrm{~mL})$ and the resulting mixture was stirred for $15 \mathrm{~h}$ at ambient temperature. The volatiles were evaporated to give crude product 97 (37 mg, 99\%) as a light yellow oil of sufficient purity to be used for next step. ${ }^{1} \mathrm{H}$ NMR $\delta 1.32(\mathrm{~s}, 3 \mathrm{H}, \mathrm{Me}), 1.49(\mathrm{~s}, 3 \mathrm{H}$, Me), 2.02 (s, 1H, OH), 3.64-3.79 (m, 3H, H4, H5, H5'), 4.96 (d, J= 5.4 Hz, 1H, H3), $5.01(\mathrm{dd}, J=5.4,10.2 \mathrm{~Hz}, 1 \mathrm{H}, \mathrm{H} 2), 5.99(\mathrm{~d}, J=55.7 \mathrm{~Hz}, 1 \mathrm{H}, \mathrm{H} 1) ;{ }^{13} \mathrm{C}$ NMR $\delta 24.43$ $\left(\mathrm{CMe}_{2}\right), 26.37\left(\mathrm{CMe}_{2}\right), 59.38$ (d, $\left.J=1.9 \mathrm{~Hz}, \mathrm{C} 4\right), 64.97$ (d, $\left.J=1.4 \mathrm{~Hz}, \mathrm{C} 5\right), 85.22$ (C3), $89.64(\mathrm{~d}, J=36.9 \mathrm{~Hz}, \mathrm{C} 2), 107.16(\mathrm{~d}, J=216.8 \mathrm{~Hz}, \mathrm{C} 1), 110.99\left(C \mathrm{Me}_{2}\right) ;{ }^{19} \mathrm{~F} \mathrm{NMR} \delta-$ $137.16(\mathrm{dd}, J=10.3,55.8 \mathrm{~Hz})$.

\section{1-Deoxy-1-fluoro-2,3- $O$-isopropylidene-5- $O$-methanesulfonyl-4-thio- $\beta$-D-}

ribofuranose (98). Compound $97(37 \mathrm{mg}, 0.18 \mathrm{mmol})$ was treated with $\mathrm{MsCl}(0.16 \mathrm{~mL}$, $237 \mathrm{mg}, 3.31 \mathrm{mmol})$ in the presence of $\mathrm{Et}_{3} \mathrm{~N}(0.6 \mathrm{~mL}, 437 \mathrm{mg}, 4.33 \mathrm{mmol})$ by Procedure A $\left(18 \mathrm{~h}, 0^{\circ} \mathrm{C} \rightarrow \mathrm{rt}\right)$. The crude product $(104 \mathrm{mg})$ was column chromatographed $(20 \% \rightarrow$ $40 \%$ EtOAc/hexane) to give 98 (31 mg, 61\%): ${ }^{1} \mathrm{H}$ NMR $\delta 1.33$ (s, 3H, Me), 1.48 (s, 3H, Me), 3.07 (s, 3H, Ms), 3.76 (ddd, $J=2.2,5.3,10.2 \mathrm{~Hz}, 1 \mathrm{H}, \mathrm{H} 4), 4.17$ ('t', $J=10.5 \mathrm{~Hz}$, 1H, H5), 4.34 (dd, $J=5.3,10.7 \mathrm{~Hz}, 1 \mathrm{H}, \mathrm{H} 5$ '), 5.01-5.03 (m, 1H, H3), 5.03-5.07 (m, 1H, H2), 5.99 (d, $J=53.6 \mathrm{~Hz}, 1 \mathrm{H}, \mathrm{H} 1) ;{ }^{13} \mathrm{C} \mathrm{NMR} \delta 24.49\left(\mathrm{CMe}_{2}\right), 26.24\left(\mathrm{CMe}_{2}\right), 37.73(\mathrm{Ms})$, 54.80 (C4), 69.85 (C5), 84.16 (C3), 88.84 (d, $J=38.6 \mathrm{~Hz}, \mathrm{C} 2), 106.58$ (d, J=218.0 Hz, C1), $111.58\left(C \mathrm{Me}_{2}\right) ;{ }^{19} \mathrm{~F}$ NMR $\delta-140.85(\mathrm{ddd}, J=1.9,8.7,53.6 \mathrm{~Hz})$.

$S$-(1,5-Dideoxy-1-fluoro-2,3-O-isopropylidene-4-thio- $\beta$-D-ribofuranos-5-yl)- $N$ (tert-butoxycarbonyl)-L-homocysteine tert-butyl ester (100), and $S$-(5-Deoxy-2,3-O- 


\section{isopropylidene-4-thio- $\beta$-D-ribofuranos-5-yl)- $N$-(tert-butoxycarbonyl)-L-}

homocysteine tert-butyl ester (101). Compound 98 (31 mg, $0.11 \mathrm{mmol})$ was treated with lithium homocysteinate $(91 \mathrm{mg}, 0.31 \mathrm{mmol})$ by Procedure $\mathrm{G}(3 \mathrm{~h})$. The crude product was column chromatographed $(15 \rightarrow 20 \%$ EtOAc/hexane) to give $100(13 \mathrm{mg}, 25 \%)$ as a colorless oil: ${ }^{1} \mathrm{H}$ NMR $\delta 1.34(\mathrm{~s}, \mathrm{Me}, 3 \mathrm{H}), 1.47$ (s, 9H), 1.49 (s, 12H), 1.85-1.95 (m, 1H, H8), 2.04-2.16 (m, 1H, H8'), 2.60-2.66 (m, 2H, H7, H7'), 2.71 (dd, J = 11.1, 13.9 Hz, 1H, H5), 2.87 (dd, $J=5.7,13.9 \mathrm{~Hz}, 1 \mathrm{H}, \mathrm{H} 5 '), 3.55$ (ddd, $J=2.3,5.4,10.9 \mathrm{~Hz}, 1 \mathrm{H}, \mathrm{H} 4), 4.26-$ 4-34 (m, 1H, H9), 5.04 (d, $J=0.8 \mathrm{~Hz}, 1 \mathrm{H}, \mathrm{H} 3), 5.06$ (d, 1, J=2.9 Hz, 1H, H2), 5.11 (br. d, $J=6.9 \mathrm{~Hz}, 1 \mathrm{H}, \mathrm{NH}), 6.00(\mathrm{~d}, J=53.7 \mathrm{~Hz}, 1 \mathrm{H}, \mathrm{H} 1) ;{ }^{13} \mathrm{C} \mathrm{NMR} \delta 24.59\left(\mathrm{CMe}_{2}\right), 26.31$ (CMe $), 28.02$ (t-Bu), 28.33 (C7, t-Bu), $33.11(\mathrm{C} 8), 38.14$ (C5), 53.32 (C9), 56.43 (d, $J=$ $1.8 \mathrm{~Hz}, \mathrm{C} 4), 79.87$ (t-Bu), 82.31 (t-Bu), 85.98 (C3), 88.86 (d, J=39.2 Hz, C2), 107.09 (d, $J=216.9 \mathrm{~Hz}, \mathrm{C} 1), 111.21\left(C \mathrm{Me}_{2}\right), 155.35(\mathrm{CO}), 171.20(\mathrm{C} 10) ;{ }^{19} \mathrm{~F}$ NMR $\delta-140.87(\mathrm{dd}, J$ $=3.8,53.8 \mathrm{~Hz}$ ); MS (ESI) $m / z 462\left(100,[\mathrm{M}-19]^{+}\right)$. HRMS (AP-ESI) $m / z$ calcd for $\mathrm{C}_{21} \mathrm{H}_{36} \mathrm{FNNaO}_{6} \mathrm{~S}_{2}[\mathrm{M}+\mathrm{Na}]^{+}$504.1860; found 504.1847.

Further elution $(25 \rightarrow 30 \%$ EtOAc/hexane) afforded $101(14 \mathrm{mg}, 27 \%)$ as a colorless oil of single $\beta$ anomer: ${ }^{1} \mathrm{H}$ NMR $\delta 1.33(\mathrm{~s}, 3 \mathrm{H}), 1.47(\mathrm{~s}, 9 \mathrm{H}), 1.49(\mathrm{~s}, 9 \mathrm{H}), 1.51(\mathrm{~s}, 3 \mathrm{H})$, 1.89-2.00 (m, 1H, H8), 2.07 (tdd, $J=5.8,9.6,13.7 \mathrm{~Hz}, 1 \mathrm{H}, \mathrm{H} 8$ '), 2.59-2.67 (m, 1H, H7), 2.68-2.77 (m, 1H, H7'), 2.85-2.94 (br., OH), 2.89 (dd, $J=8.7,13.5$ Hz, 1H, H5), 2.97 (dd, $\left.J=6.8,13.6 \mathrm{~Hz}, 1 \mathrm{H}, \mathrm{H}^{\prime}\right), 3.56$ (t, $\left.J=7.9 \mathrm{~Hz}, 1 \mathrm{H}, \mathrm{H} 4\right), 4.27-4-35$ (m, 1H, H9), 4.87 (d, $J=5.4 \mathrm{~Hz}, 1 \mathrm{H}, \mathrm{H} 2), 4.95$ (d, 1, $J=5.4 \mathrm{~Hz}, 1 \mathrm{H}, \mathrm{H} 3), 5.18$ (br. d, $J=6.9 \mathrm{~Hz}, 1 \mathrm{H}, \mathrm{NH})$, $5.41(\mathrm{~s}, 1 \mathrm{H}, \mathrm{H} 1) ;{ }^{13} \mathrm{C}$ NMR $\delta 24.61\left(\mathrm{CMe}_{2}\right), 26.48\left(\mathrm{CMe}_{2}\right), 28.03(\mathrm{t}-\mathrm{Bu}), 28.26(\mathrm{C} 7)$, 28.34 (t-Bu) 33.05 (C8), 38.34 (C5), 53.31 (C9), 56.92 (C4), $80.01(\mathrm{t}-\mathrm{Bu}), 82.39$ (t-Bu), 87.37 (C1), 87.65 (C3), 90.22 (C2), $110.67\left(\mathrm{CMe}_{2}\right), 155.39$ (CO), 171.21 (C10); MS 
(ESI) $m / z 462\left(100,[\mathrm{M}-17]^{+}\right) 480\left(30,[\mathrm{MH}]^{+}\right)$; HRMS (ESI) $m / z$ calcd for $\mathrm{C}_{21} \mathrm{H}_{37} \mathrm{NNaO}_{7} \mathrm{~S}_{2}[\mathrm{M}+\mathrm{Na}]^{+}$502.1909; found 502.1884.

$\boldsymbol{S}$-(5-Deoxy-4-thio-D-ribofuranos-5-yl)-L-homocysteine (39). Method $A$. Compound 100 (13 mg, $0.027 \mathrm{mmol}$ ) was treated with aqueous TFA by Procedure H (4 h) to give colorless oil of $\mathbf{3 9}$ (7 $\mathrm{mg}, 91 \%)$ as a mixture of anomers whose ratio changed when stored as $\mathrm{D}_{2} \mathrm{O}$ solution $(1: 1 \rightarrow 1: 4, \alpha: \beta)$. Major $\beta$-isomer had: ${ }^{1} \mathrm{H}$ NMR $\left(\mathrm{D}_{2} \mathrm{O}\right) \delta$ 2.25-2.45 (m, 2H, H8, H8'), 2.78 (dd, $J=8.7,13.4 \mathrm{~Hz}, 1 \mathrm{H}, \mathrm{H} 5), 2.87$ (t, $J=7.3 \mathrm{~Hz}, 2 \mathrm{H}$, H7, H7'), 3.20 (dd, $\left.J=4.6,13.4 \mathrm{~Hz}, 1 \mathrm{H}, \mathrm{H} 5^{\prime}\right), 3.54$ (ddd, $J=4.6,7.8,9.0 \mathrm{~Hz}, 1 \mathrm{H}, \mathrm{H} 4$ ), 4.16-4.21 (m, 3H, H2, H3, H9), $5.16(\mathrm{~d}, J=1.6 \mathrm{~Hz}, 1 \mathrm{H}, \mathrm{H} 1) ;{ }^{13} \mathrm{C} \mathrm{NMR}\left(\mathrm{D}_{2} \mathrm{O}\right) \delta 29.20$ (C8), 32.32 (C7), 35.68 (C5), 48.81 (C4), 51.69 (C9), 76.75, 79.64 (C2, C3), 81.08 (C1), 171.75 (C10). Minor $\alpha$-isomer had: ${ }^{1} \mathrm{H}$ NMR $\left(\mathrm{D}_{2} \mathrm{O}\right) \delta$ 2.25-2.45 (m, 2, H8, H8'), 2.67 (dd, $J=8.7,13.5 \mathrm{~Hz}, 1 \mathrm{H}, \mathrm{H}$ ), 2.87 (t, $\left.J=7.3 \mathrm{~Hz}, 2 \mathrm{H}, \mathrm{H} 7, \mathrm{H} 7{ }^{\prime}\right), 3.03$ (dd, $J=5.5,13.4 \mathrm{~Hz}$, 1H, H5'), 3.77 (dt, $J=5.6,8.7, \mathrm{~Hz}, 1 \mathrm{H}, \mathrm{H} 4), 4.10$ (dd, $J=3.7,5.7 \mathrm{~Hz}, 1 \mathrm{H}, \mathrm{H} 3), 4.16-4.21$ (m, 1H, H9), 4.24 (t, $J=4.0 \mathrm{~Hz}, 1 \mathrm{H}, \mathrm{H} 2), 5.45$ (d, $J=4.3 \mathrm{~Hz}, 1 \mathrm{H}, \mathrm{H} 1)$; MS (ESI) $\mathrm{m} / \mathrm{z}$ $284\left(100,[\mathrm{MH}]^{+}\right)$. HRMS (AP-ESI) $m / z$ calculated for $\mathrm{C}_{9} \mathrm{H}_{16} \mathrm{NO}_{5} \mathrm{~S}_{2}[\mathrm{M}-\mathrm{H}]^{-} 282.0475$; found 282.0484 .

Method B. Compound $101(6 \mathrm{mg}, 0.012 \mathrm{mmol})$ was treated with aqueous TFA by Procedure $\mathrm{H}(4 \mathrm{~h})$ to give $\mathbf{3 9}$ (3 $\mathrm{mg}, 85 \%)$ as a colorless oil with spectral data identical to the sample of $\mathbf{3 9}$ obtained from Method A. 


\subsection{Biological Assays}

\subsubsection{Anti-QS assay for 4-[thia]-SRH}

\subsubsection{1. $\beta$-galactosidase assay}

An overnight culture of $E$. coli $\mathrm{DH} 5 \alpha$ harboring the plasmids $\mathrm{pSC} 11$, which contains

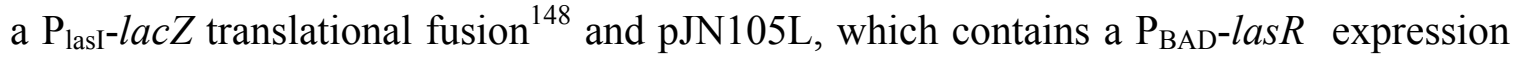
plasmid $^{149}$ grown in LB media (10 g tryptone, $5 \mathrm{~g}$ yeast extract, $5 \mathrm{~g}$ sodium chloride per liter) supplemented with ampillicin $(100 \mu \mathrm{g} / \mathrm{ml})$ and gentamycin $(15 \mu \mathrm{g} / \mathrm{ml})$, was diluted to an $\mathrm{OD}_{600}$ of 0.150 . At this time, arabinose $(0.2 \% \quad \mathrm{w} / \mathrm{v}), \quad N-3-$ (oxododecanoyl)homoserine lactone (3-oxo- $\mathrm{C}_{12}$-AHL; $2 \mu \mathrm{M}$ ), and either the compound under analysis, water extract from Conocarpus erectus or Callistemon viminalis ${ }^{150}$ or solvent (water or DMSO), were added to the culture $(1.5 \mathrm{~mL})$. A negative control containing only solvent and arabinose $(0.2 \% \mathrm{w} / \mathrm{v})$ was also assayed. The cultures were incubated with shaking for three hours at $37^{\circ} \mathrm{C}$.

The conditions for the $r h l$ biomonitor E. coli DH5a harboring pECP61.5 plasmid $^{151}$, were essentially same except that the LB medium was only supplemented with ampillicin $(100 \mu \mathrm{g} / \mathrm{ml})$, the overnight culture was diluted to an OD600 of 0.150 , induced with 1 $\mathrm{mM}$ isopropyl $\beta$-D-thiogalactoside (IPTG), $2 \mu \mathrm{M} \mathrm{C}$-AHL and the compounds or the controls added when the $\mathrm{OD}_{600}$ reached 1.0. After incubation at $37{ }^{\circ} \mathrm{C}$ for 4 hours with shaking, $\beta$-galactosidase activity was assayed as described previously. ${ }^{152}$ Assays were repeated at least twice. For each biological replicate, experimental triplicates were performed and the average percent activity calculated by dividing the average Miller units from the samples containing compound or extract by the average Miller units from 
the sample containing solvent and multiplying by 100 . Significance of inhibition was determined using a paired two-tailed Student $t$-test.

\subsubsection{Growth and luminescence measurement drop assay}

Growth and luminescence measurement drop assays were conducted by Professor Makemson at FIU. The $V$. harveyi strain B392 (MAV) (or strain BB170 (AI-1- ${ }^{-} \mathrm{AI}-2^{+}$) or strain $\mathrm{BB} 152\left(\mathrm{AI}-1^{-}, \mathrm{AI}-2^{+}\right)$, was grown in $\mathrm{AB}$ medium $(75 \%$ artificial sea water, $0.3 \%$ glycerol, $0.2 \%$ casamino acids, $0.02 \%$ glycerol-phosphate, $25 \mathrm{mM}$ HEPES buffer) at a $\mathrm{pH} 7.5^{153}$ Growth was measured in a Spectronic 20 as $\mathrm{OD}_{660 \mathrm{~nm}}$ and luminescence was measured in a calibrated photometer and recorded in light units $\left(1 \mathrm{LU}=1.08 \times 10^{8}\right.$ $\mathrm{q} / \mathrm{s} / \mathrm{mL}$ ). An overnight culture of $V$. harveyi was added to $45 \mathrm{~mL}$ of $\mathrm{AB}$ medium to an $\mathrm{OD}_{660 \mathrm{~nm}}$ of $\sim 0.03$, When the culture was rapidly growing $\left(\mathrm{OD}_{660 \mathrm{~nm}} \sim 0.05\right.$ to 0.07$)$, the culture was split $(2.5 \mathrm{~mL} / 13 \times 100 \mathrm{~mm}$ culture tubes) and small amounts $(2.5 \mu \mathrm{L}$ and 10 $\mu \mathrm{L})$ of each compound were added to each tube. The compound, dissolved in water or DMSO served as a control. Each measurement was obtained from a single trial and luminescence without inhibitor was considered $100 \%$.

\subsubsection{Anti-QS assay for 4- $C$-alkyl/aryl-SRH}

The 4-C-alkyl/aryl-[SRH] analogues and the 4-[thia]-SRH analogues synthesized in this dissertation will be evaluated for the inhibition of LuxS enzyme in the laboratoty of Professor Dehua Pei at the University of Ohio. 


\section{CONCLUSION}

I have developed different strategies for the synthesis of the three novel classes of $S$ ribosylhomocysteine (SRH) analogues which were designed as potential inhibitors of the S-ribosylhomocyteinase enzyme (LuxS). The first class I attempted to prepare was 2halo-SRH analogues. The 2-deoxy-2-fluoro pentafuranosyl precursors were prepared from the D-allose in a multistep procedure, which involved dehomologation and intramolecular rearrangement of the 3-deoxy-3-fluoroglucose to 2-deoxy-2fluoroarabinose. The 2-bromo-2-deoxy pentafuranosyl precursors were prepared by direct bromination of the suitably protected 2-deoxyribono-1,4-lactone with $\mathrm{N}$ bromosuccinimide in the presence of trimethylsilyl triflate resulting in the formation of 2bromo-2-deoxyribono-1,4-lactones as a mixture of arabino/ribo epimers in 2:1 ratio. The 5-hydroxyl group in 2-bromo-2-deoxyarabinono-1,4-lactones was activated by the conversion to the methylsulfonate ester. However attempts of the displacement of the mesylate group with the suitably protected homocysteinate anion led to the substitution of the secondary bromine at the $\alpha$-position to the carbonyl group in ribonolactones rather than the replacement of the primary mesylate group. Model reaction with propanethiol confirmed that the displacement of the bromide from $\mathrm{C} 2$ takes precedence over the substitution of the mesylate from the C5 leading to the formation 2-S-propyl substituted 2-thioribonolactone.

The second class was the 4-C-alkyl/aryl-S-ribosylhomocysteine analogues synthesis of which was accomplished from D-ribose. The preparation of the ribono-1,4-lactone analogues of 4-C-substituted SRH involved the following critical steps: (i) conversion of the D-ribose to the ribitol-4-ulose; (ii) diastereoselective addition of various alkyl or aryl 
or vinyl Grignard reagents to 4-ketone intermediate; (iii) oxidation of the primary hydroxyl group at $\mathrm{C} 1$ followed by the intramolecular ring closure to the corresponding 4C-alkyl/aryl-substituted ribono-1,4-lactones; (iv) displacement of the activated 5hydroxyl group with the protected homocysteinate. Treatment of these 4-C-alkyl/arylsubstituted SRH analogues with lithium triethylborohydride effected reduction of the ribonolactone to the ribose (hemiacetal) and subsequent global deprotection with trifluoroacetic acid provided 4-C-alkyl/aryl-SRHs.

The third class was the 4-[thia]-SRH analogues synthesis which started from the 1-deoxy-4-thioribose which was in turns prepared from D-ribose. Treatment of the 1deoxy-4-thioribose thioether or the corresponding sulfoxides with $\mathrm{DAST} / \mathrm{SbCl}_{3}$ combination resulted in the fluoro-Pummerer rearrangement to give the corresponding thioribosyl fluorides in high yields. These $\alpha$-fluoro thioethers were sensitive to acidic conditions and underwent hydrolysis to the corresponding thiohemiacetals. However, the $\alpha$-fluoro thioethers (thioribosyl fluorides) were relatively stable to basic conditions, in parallel with acetals. Thus, ribosyl fluorides were mesylated at primary 5-hydroxyl and subsequent coupling with the protected homocysteinate anion afforded the relatively stable 4-[thia]-SRH fluoride. Treatment of the latter with aqueous TFA effected hydrolysis of the fluoride as well as the global removal of the $N$-Boc, acetonide, and $t$ butyl ester protection groups in a single step to give 4-[thia]-SRH derivative as a mixture of $\alpha: \beta$ anomers.

The 4-[thia]-SRH analogues were evaluated for their effect on P. aeruginosa QS. All the tested 4-[thia] derivatives showed a general concentration-dependent (50-200 $\mu \mathrm{G} / \mathrm{mL}$ ) inhibition of las QS pathways, while none of them affected $r h l$ gene. The most 
active was 1-deoxy-4-[thia]-SRH analogue with the sufur atom in the ring oxidized to the sulfoxide decreasing las gene activity to approximately $35 \%$. In addition 4-[thia]-SRH analogues were tested for their effect on QS, bioluminescence and growth of the $V$. harveyi. They did not display any significant effects. The interaction of the prepared SRH analogues with LuxS and their effect in other QS sytems are currently being evaluated in the collaboration with other research groups.

Future research direction will depend on the results generated from the interaction of the synthesized analogues of SRH with LuxS enzyme. It might, however, involve the synthesis of different thio-DPD and aza-DPD analogues and study their borate complexation to help us to understand better the mechanism of action and the binding properties. The bulky 4-C-alkyl/aryl SRH should be used to study dimer interface of LuxS and the disruption of the dimerization processes. The use of the fluorescence proximity assay, which is a technique used to test the inhibition of a dimeric protein in presence of an inhibitor by measuring the change in fluorescence upon monomer separation, can be used in future studies. 


\section{REFERENCES}

1. Chen, X.; Schauder, S.; Potier, N.; Van Dorsselaer, A.; Pelczer, I.; Bassler, B. L.; Hughson, F. M., Structural identification of a bacterial quorum-sensing signal containing boron. Nature 2002, 415, 545-549.

2. Chen, G.; Swem, Lee R.; Swem, Danielle L.; Stauff, Devin L.; O'Loughlin, Colleen T.; Jeffrey, Philip D.; Bassler, Bonnie L.; Hughson, Frederick M., A Strategy for Antagonizing Quorum Sensing. Mol. Cell 2011, 42, 199-209.

3. Pereira, C. S.; Thompson, J. A.; Xavier, K. B., AI-2-mediated signalling in bacteria. FEMS Microbiol. Rev. 2013, 37, 156-181.

4. Waters, C. M.; Bassler, B. L., Quorum sensing: cell-to-cell communication in bacteria. Annu. Rev. Cell Dev. Biol. 2005, 21, 319-346.

5. Suga, H.; Smith, K. M., Molecular mechanisms of bacterial quorum sensing as a new drug target. Curr. Opin. Chem. Biol. 2003, 7, 586-591.

6. Praneenararat, T.; Geske, G. D.; Blackwell, H. E., Efficient Synthesis and Evaluation of Quorum-Sensing Modulators Using Small Molecule Macroarrays. Org. Lett. 2009, 11, 4600-4603.

7. Gonzalez, J. E.; Keshavan, N. D., Messing with bacterial quorum sensing. Microbiol. Mol. Biol. Rev. 2006, 70, 859-870.

8. Williams, P., Quorum sensing, communication and cross-kingdom signalling in the bacterial world. Microbiology 2007, 153, 3923-3938.

9. Williams, P.; Winzer, K.; Chan, W. C.; Camara, M., Look who's talking: communication and quorum sensing in the bacterial world. Philos. Trans. R. Soc. 2007, 362, 1119-1134.

10. Kalia, V. C., Quorum sensing inhibitors: an overview. Biotechnol. Adv. 2013, 31, 224-45.

11. Mattmann, M. E.; Blackwell, H. E., Small Molecules That Modulate Quorum Sensing and Control Virulence in Pseudomonas aeruginosa. J. Org. Chem. 2010, 75, 6737-6746.

12. Galloway, W. R. J. D.; Hodgkinson, J. T.; Bowden, S. D.; Welch, M.; Spring, D. R., Quorum Sensing in Gram-Negative Bacteria: Small-Molecule Modulation of AHL and Al-2 Quorum Sensing Pathways. Chem. Rev. 2011, 111, 28-67. 
13. Vendeville, A.; Winzer, K.; Heurlier, K.; Tang, C. M.; Hardie, K. R., Making 'sense' of metabolism: Autoinducer-2, LuxS and pathogenic bacteria. Nat. Rev. Microbiol. 2005, 3, 383-396.

14. De Keersmaecker, S. C.; Sonck, K.; Vanderleyden, J., Let LuxS speak up in AI-2 signaling. Trends Microbiol. 2006, 14, 114-119.

15. Xavier, K. B.; Bassler, B. L., LuxS quorum sensing: more than just a numbers game. Curr. Opin. Microbiol. 2003, 6, 191-197.

16. Duan, K.; Dammel, C.; Stein, J.; Rabin, H.; Surette, M. G., Modulation of Pseudomonas aeruginosa gene expression by host microflora through interspecies communication. Mol. Microbiolol. 2003, 50, 1477-1491.

17. Ni, N.; Li, M.; Wang, J.; Wang, B., Inhibitors and antagonists of bacterial quorum sensing. Med. Res. Rev. 2009, 29, 65-124.

18. Roy, V.; Adams, B. L.; Bentley, W. E., Developing next generation antimicrobials by intercepting AI-2 mediated quorum sensing. Enzyme Microb. Technol. 2011, 49, 113-123.

19. Alfaro, J. F.; Zhang, T.; Wynn, D. P.; Karschner, E. L.; Zhou, Z. S., Synthesis of LuxS inhibitors targeting bacterial cell-cell communication. Org. Lett. 2004, 6, 3043-3046.

20. Ng, W. L.; Bassler, B. L., Bacterial Quorum-Sensing Network Architectures. Annu. Rev. Genet. 2009, 43, 197-222.

21. Blackwell, H. E.; Fuqua, C., Introduction to bacterial signals and chemical communication. Chem. Rev. 2011, 111, 1-3.

22. Walters, M.; Sperandio, V., Autoinducer 3 and epinephrine signaling in the kinetics of locus of enterocyte effacement gene expression in enterohemorrhagic Escherichia coli. Infect. Immun. 2006, 74, 5445-5455.

23. Higgins, D. A.; Pomianek, M. E.; Kraml, C. M.; Taylor, R. K.; Semmelhack, M. F.; Bassler, B. L., The major Vibrio cholerae autoinducer and its role in virulence factor production. Nature 2007, 450, 883-886.

24. Zhu, J.; Kaufmann, G. F., Quo vadis quorum quenching? Curr. Opin. Pharmacol. 2013, 13, 688-698.

25. Lyon, G. J.; Muir, T. W., Chemical signaling among bacteria and its inhibition. Chem. Biol. 2003, 10, 1007-1021. 
26. Kleerebezem, M.; Quadri, L. E. N.; Kuipers, O. P.; deVos, W. M., Quorum sensing by peptide pheromones and two-component signal-transduction systems in Gram-positive bacteria. Mol. Microbiol. 1997, 24, 895-904.

27. Campbell, J.; Lin, Q.; Geske, G. D.; Blackwell, H. E., New and Unexpected Insights into the Modulation of LuxR-Type Quorum Sensing by Cyclic Dipeptides. Chem. Biol. 2009, 4, 1051-1059.

28. Fuqua, C.; Greenberg, E. P., Listening in on bacteria: acyl-homoserine lactone signalling. Nat. Rev. Mol. Cell Biol. 2002, 3, 685-695.

29. Swift, S.; Karlyshev, A. V.; Fish, L.; Durant, E. L.; Winson, M. K.; Chhabra, S. R.; Williams, P.; MacIntyre, S.; Stewart, G. S. A. B., Quorum sensing in Aeromonas hydrophila and Aeromonas salmonicida: Identification of the LuxRI homologs AhyRI and AsaRI and their cognate N-acylhomoserine lactone signal molecules. J. Bacteriol. 1997, 179, 5271-5281.

30. Sokol, P. A.; Sajjan, U.; Visser, M. B.; Gingues, S.; Forstner, J.; Kooi, C., The CepIR quorum-sensing system contributes to the virulence of Burkholderia cenocepacia respiratory infections. Microbiology 2003, 149, 3649-3658.

31. McClean, K. H.; Winson, M. K.; Fish, L.; Taylor, A.; Chhabra, S. R.; Camara, M.; Daykin, M.; Lamb, J. H.; Swift, S.; Bycroft, B. W.; Stewart, G. S. A. B.; Williams, P., Quorum sensing and Chromobacterium violaceum: exploitation of violacein production and inhibition for the detection of $\mathrm{N}$-acylhomoserine lactones. Microbiology 1997, 143, 3703-3711.

32. Welch, M.; Dutton, J. M.; Glansdorp, F. G.; Thomas, G. L.; Smith, D. S.; Coulthurst, S. J.; Barnard, A. M.; Salmond, G. P.; Spring, D. R., Structure-activity relationships of Erwinia carotovora quorum sensing signaling molecules. Bioorg. Med. Chem. Lett. 2005, 15, 4235-4238.

33. Nasser, W.; Bouillant, M. L.; Salmond, G.; Reverchon, S., Characterization of the Erwinia chrysanthemi expI-expR locus directing the synthesis of two N-acylhomoserine lactone signal molecules. Mol. Microbiol. 1998, 29, 1391-1405.

34. Zhang, Z. G.; Pierson, L. S., A second quorum-sensing system regulates cell surface properties but not phenazine antibiotic production in Pseudomonas aureofaciens. Appl. Environ. Microbiol. 2001, 67, 4305-4315.

35. Smith, R. S.; Harris, S. G.; Phipps, R.; Iglewski, B., The Pseudomonas aeruginosa quorum-sensing molecule $\mathrm{N}$-(3-oxododecanoyl)homoserine lactone contributes to virulence and induces inflammation in vivo. J. Bacteriol. 2002, 184, 1132-1139. 
36. Jiang, Y.; Camara, M.; Chhabra, S. R.; Hardie, K. R.; Bycroft, B. W.; Lazdunski, A.; Salmond, G. P.; Stewart, G. S.; Williams, P., In vitro biosynthesis of the Pseudomonas aeruginosa quorum-sensing signal molecule N-butanoyl-Lhomoserine lactone. Mol. Microbiol. 1998, 28, 193-203.

37. Puskas, A.; Greenberg, E. P.; Kaplan, S.; Schaefer, A. L., A quorum-sensing system in the free-living photosynthetic bacterium Rhodobacter sphaeroides. $J$. Bacteriol. 1997, 179, 7530-7537.

38. Eberl, L.; Winson, M. K.; Sternberg, C.; Stewart, G. S.; Christiansen, G.; Chhabra, S. R.; Bycroft, B.; Williams, P.; Molin, S.; Givskov, M., Involvement of $\mathrm{N}$-acyl-L-hormoserine lactone autoinducers in controlling the multicellular behaviour of Serratia liquefaciens. Mol. Microbiol. 1996, 20, 127-136.

39. Callahan, S. M.; Dunlap, P. V., LuxR- and acyl-homoserine-lactone-controlled non-lux genes define a quorum-sensing regulon in Vibrio fischeri. J. Bacteriol. 2000, 182, 2811-2822.

40. Cao, J. G.; Meighen, E. A., Purification and structural identification of an autoinducer for the luminescence system of Vibrio harveyi. J. Biol. Chem. 1989, 264, 21670-21676.

41. Kirwan, J. P.; Gould, T. A.; Schweizer, H. P.; Bearden, S. W.; Murphy, R. C.; Churchill, M. E., Quorum-sensing signal synthesis by the Yersinia pestis acylhomoserine lactone synthase YspI. J. Bacteriol. 2006, 188, 784-788.

42. Roy, V.; Fernandes, R.; Tsao, C.-Y.; Bentley, W. E., Cross Species Quorum Quenching Using a Native AI-2 Processing Enzyme. Chem. Biol. 2009, 5, 223232.

43. Mead, P. S.; Slutsker, L.; Dietz, V.; McCaig, L. F.; Bresee, J. S.; Shapiro, C.; Griffin, P. M.; Tauxe, R. V., Food-related illness and death in the United States. Emerg. Inf. Dis. 1999, 5, 607-625.

44. Schauder, S.; Shokat, K.; Surette, M. G.; Bassler, B. L., The LuxS family of bacterial autoinducers: biosynthesis of a novel quorum-sensing signal molecule. Mol. Microbiol. 2001, 41, 463-476.

45. Semmelhack, M. F.; Campagna, S. R.; Federle, M. J.; Bassler, B. L., An expeditious synthesis of DPD and boron binding studies. Org. Lett. 2005, 7, 569572.

46. Xavier, K. B.; Bassler, B. L., Regulation of uptake and processing of the quorumsensing autoinducer AI-2 in Escherichia coli. J. Bacteriol. 2005, 187, 238-248. 
47. Bassler, B. L.; Wright, M.; Silverman, M. R., Multiple signalling systems controlling expression of luminescence in Vibrio harveyi: sequence and function of genes encoding a second sensory pathway. Mol. Microbiol. 1994, 13, 273-286.

48. Henke, J. M.; Bassler, B. L., Three parallel quorum-sensing systems regulate gene expression in Vibrio harveyi. J. Bacteriol. 2004, 186, 6902-6914.

49. Defoirdt, T.; Boon, N.; Sorgeloos, P.; Verstraete, W.; Bossier, P., Quorum sensing and quorum quenching in Viabrio harveyi: lessons learned from in vivo work. Int. Soc. Microb. Eco 2008, 2, 19-26.

50. Zhu, J.; Mekalanos, J. J., Quorum sensing-dependent biofilms enhance colonization in Vibrio cholerae. Dev. cell. 2003, 5, 647-656.

51. Zhu, J.; Miller, M. B.; Vance, R. E.; Dziejman, M.; Bassler, B. L.; Mekalanos, J. J., Quorum-sensing regulators control virulence gene expression in Vibrio cholerae. Proc. Natl. Acad. Sci. U. S. A. 2002, 99, 3129-3134.

52. Vance, R. E.; Zhu, J.; Mekalanos, J. J., A constitutively active variant of the quorum-sensing regulator LuxO affects protease production and biofilm formation in Vibrio cholerae. Infect. Immun. 2003, 71, 2571-2576.

53. Hammer, B. K.; Bassler, B. L., Quorum sensing controls biofilm formation in Vibrio cholerae. Mol. Microbiol. 2003, 50, 101-104.

54. Emori, T. G.; Gaynes, R. P., An Overview of Nosocomial Infections, Including the Role of the Microbiology Laboratory. Clin. Microbiol. Rev. 1993, 6, 428-442.

55. Ishida, T.; Ikeda, T.; Takiguchi, N.; Kuroda, A.; Ohtake, H.; Kato, J., Inhibition of quorum sensing in Pseudomonas aeruginosa by $\mathrm{N}$-acyl cyclopentylamides. Appl. Environ. Microbiol. 2007, 73, 3183-3188.

56. Smith, K. M.; Bu, Y. G.; Suga, H., Induction and inhibition of Pseudomonas aeruginosa quorum sensing by synthetic autoinducer analogs. Chem. Biol. 2003, 10, 81-89.

57. Bassler, B. L., How bacteria talk to each other: regulation of gene expression by quorum sensing. Curr. Opin. Microbiol. 1999, 2, 582-587.

58. Pesci, E. C.; Pearson, J. P.; Seed, P. C.; Iglewski, B. H., Regulation of las and rhl quorum sensing in Pseudomonas aeruginosa. J. Bacteriol. 1997, 179, 3127-3132.

59. Smith, R. S.; Iglewski, B. H., P. aeruginosa quorum-sensing systems and virulence. Curr. Opin. Microbiol. 2003, 6, 56-60. 
60. Shen, G.; Rajan, R.; Zhu, J. G.; Bell, C. E.; Pei, D. H., Design and synthesis of substrate and intermediate analogue inhibitors of S-ribosylhomocysteinase. $J$. Med. Chem. 2006, 49, 3003-3011.

61. Zhu, J. G.; Dizin, E.; Hu, X. B.; Wavreille, A. S.; Park, J.; Pei, D. H., Sribosylhomocysteinase (LuxS) is a mononuclear iron protein. Biochem. 2003, 42, 4717-4726.

62. Lewis, H. A.; Furlong, E. B.; Laubert, B.; Eroshkina, G. A.; Batiyenko, Y.; Adams, J. M.; Bergseid, M. G.; Marsh, C. D.; Peat, T. S.; Sanderson, W. E.; Sauder, J. M.; Buchanan, S. G., A structural genomics approach to the study of quorum sensing: crystal structures of three LuxS orthologs. Structure 2001, 9, 527-537.

63. Ruzheinikov, S. N.; Das, S. K.; Sedelnikova, S. E.; Hartley, A.; Foster, S. J.; Horsburgh, M. J.; Cox, A. G.; McCleod, C. W.; Mekhalfia, A.; Blackburn, G. M.; Rice, D. W.; Baker, P. J., The 1.2 A structure of a novel quorum-sensing protein, Bacillus subtilis LuxS. J. Mol. Biol. 2001, 313, 111-122.

64. Hilgers, M. T.; Ludwig, M. L., Crystal structure of the quorum-sensing protein LuxS reveals a catalytic metal site. Proc. Natl. Acad. Sci. U. S. A. 2001, 98, 11169-11174.

65. Jones, S.; Thornton, J. M., Protein-protein interactions: a review of protein dimer structures. Prog. Biophys. Mol. Biol. 1995, 63, 31-65.

66. Pei, D. H.; Zhu, J. G., Mechanism of action S-ribosylhomocysteinase (LuxS). Curr. Opin. Chem. Biol. 2004, 8, 492-497.

67. Zhu, J.; Hu, X.; Dizin, E.; Pei, D., Catalytic mechanism of Sribosylhomocysteinase (LuxS): direct observation of ketone intermediates by $13 \mathrm{C}$ NMR spectroscopy. J. Am. Chem. Soc. 2003, 125, 13379-13381.

68. Surette, M. G.; Miller, M. B.; Bassler, B. L., Quorum sensing in Escherichia coli, Salmonella typhimurium, and Vibrio harveyi: A new family of genes responsible for autoinducer production. Proc. Natl. Acad. Sci. U. S. A. 1999, 96, 1639-1644.

69. Schauder, S.; Bassler, B. L., The languages of bacteria. Genes Dev. 2001, 15, 1468-1480.

70. Miller, M. B.; Bassler, B. L., Quorum sensing in bacteria. Annu. Rev. Microbiol. 2001, 55, 165-199.

71. Tavender, T. J.; Halliday, N. M.; Hardie, K. R.; Winzer, K., LuxS-independent formation of Al-2 from ribulose-5-phosphate. BMC Microbiol. 2008, 8, 200-208. 
72. Neiditch, M. B.; Federle, M. J.; Pompeani, A. J.; Kelly, R. C.; Swem, D. L.; Jeffrey, P. D.; Bassler, B. L.; Hughson, F. M., Ligand-induced asymmetry in histidine sensor kinase complex regulates quorum sensing. Cell 2006, 126, 10951108 .

73. Miller, S. T.; Xavier, K. B.; Campagna, S. R.; Taga, M. E.; Semmelhack, M. F.; Bassler, B. L.; Hughson, F. M., Salmonella typhimurium recognizes a chemically distinct form of the bacterial quorum-sensing signal AI-2. Mol. Cell 2004, 15, 677-687.

74. Federle, M. J.; Bassler, B. L., Interspecies communication in bacteria. J. Clin. Invest. 2003, 112, 1291-1299.

75. Kaper, J. B.; Sperandio, V., Bacterial cell-to-cell signaling in the gastrointestinal tract. Infect. Immun. 2005, 73, 3197-3209.

76. Winzer, K.; Hardie, K. R.; Burgess, N.; Doherty, N.; Kirke, D.; Holden, M. T.; Linforth, R.; Cornell, K. A.; Taylor, A. J.; Hill, P. J.; Williams, P., LuxS: its role in central metabolism and the in vitro synthesis of 4-hydroxy-5-methyl-3(2H)furanone. Microbiology 2002, 148, 909-922.

77. Knowles, F. C.; Chanley, J. D.; Pon, N. G., Spectral changes arising from the action of spinach chloroplast ribosephosphate isomerase on ribose 5-phosphate. Arch. Biochem. Biophys. 1980, 202, 106-115.

78. Hauck, T.; Landmann, C.; Bruhlmann, F.; Schwab, W., Formation of 5-methyl-4hydroxy-3[2H]-furanone in cytosolic extracts obtained from Zygosaccharomyces rouxii. J. Agric. Food. Chem. 2003, 51, 1410-1414.

79. Meijler, M. M.; Hom, L. G.; Kaufmann, G. F.; McKenzie, K. M.; Sun, C.; Moss, J. A.; Matsushita, M.; Janda, K. D., Synthesis and biological validation of a ubiquitous quorum-sensing molecule. Angew. Chem. Int. Ed. Engl. 2004, 43, 2106-2108.

80. Kadirvel, M.; Stimpson, W. T.; Moumene-Afifi, S.; Arsic, B.; Glynn, N.; Halliday, N.; Williams, P.; Gilbert, P.; McBain, A. J.; Freeman, S.; Gardiner, J. M., Synthesis and bioluminescence-inducing properties of autoinducer (S)-4,5dihydroxypentane-2,3-dione and its enantiomer. Bioorg. Med. Chem. Lett. 2010, 20, 2625-2628.

81. Geske, G. D.; O'Neill, J. C.; Blackwell, H. E., Expanding dialogues: from natural autoinducers to non-natural analogues that modulate quorum sensing in Gramnegative bacteria. Chem. Soc. Rev. 2008, 37, 1432-1447. 
82. Han, X.; Lu, C., Biological activity and identification of a peptide inhibitor of LuxS from Streptococcus suis serotype 2. FEMS Microbiol. Lett. 2009, 294, 1623.

83. Zhao, G.; Wan, W.; Mansouri, S.; Alfaro, J. F.; Bassler, B. L.; Cornell, K. A.; Zhou, Z. S., Chemical synthesis of S-ribosyl-L-homocysteine and activity assay as a LuxS substrate. Bioorg. Med. Chem. Lett. 2003, 13, 3897-3900.

84. Gutierrez, J. A.; Crowder, T.; Rinaldo-Matthis, A.; Ho, M. C.; Almo, S. C.; Schramm, V. L., Transition state analogs of 5'-methylthioadenosine nucleosidase disrupt quorum sensing. Nat. Chem. Biol. 2009, 5, 251-257.

85. Chung, J.; Goo, E.; Yu, S.; Choi, O.; Lee, J.; Kim, J.; Kim, H.; Igarashi, J.; Suga, H.; Moon, J. S.; Hwang, I.; Rhee, S., Small-molecule inhibitor binding to an Nacyl-homoserine lactone synthase. Proc. Natl. Acad. Sci. U. S. A. 2011, 108, 12089-12094.

86. Dong, Y. H.; Zhang, L. H., Quorum sensing and quorum-quenching enzymes. J. Microbiol. 2005, 43, 101-109.

87. Kaufmann, G. F.; Sartorio, R.; Lee, S. H.; Mee, J. M.; Altobell, L. J., 3rd; Kujawa, D. P.; Jeffries, E.; Clapham, B.; Meijler, M. M.; Janda, K. D., Antibody interference with $\mathrm{N}$-acyl homoserine lactone-mediated bacterial quorum sensing. J. Am. Chem. Soc. 2006, 128, 2802-2803.

88. Park, J.; Jagasia, R.; Kaufmann, G. F.; Mathison, J. C.; Ruiz, D. I.; Moss, J. A.; Meijler, M. M.; Ulevitch, R. J.; Janda, K. D., Infection control by antibody disruption of bacterial quorum sensing signaling. Chem. Biol. 2007, 14, 11191127.

89. Kapadnis, P. B.; Hall, E.; Ramstedt, M.; Galloway, W. R.; Welch, M.; Spring, D. R., Towards quorum-quenching catalytic antibodies. Chem. Commun. 2009, 538540.

90. Lyon, G. J.; Mayville, P.; Muir, T. W.; Novick, R. P., Rational design of a global inhibitor of the virulence response in Staphylococcus aureus, based in part on localization of the site of inhibition to the receptor-histidine kinase, AgrC. Proc. Natl. Acad. Sci. U. S. A. 2000, 97, 13330-13335.

91. Amara, N.; Mashiach, R.; Amar, D.; Krief, P.; Spieser, S. p. A. H.; Bottomley, M. J.; Aharoni, A.; Meijler, M. M., Covalent Inhibition of Bacterial Quorum Sensing. J. Am. Chem. Soc. 2009, 131, 10610-10619.

92. Geske, G. D.; O'Neill, J. C.; Miller, D. M.; Mattmann, M. E.; Blackwell, H. E., Modulation of bacterial quorum sensing with synthetic ligands: systematic 
evaluation of $\mathrm{N}$-acylated homoserine lactones in multiple species and new insights into their mechanisms of action. J. Am. Chem. Soc. 2007, 129, 1361313625 .

93. Varga, Z. G.; Armada, A.; Cerca, P.; Amaral, L.; Mior Ahmad Subki, M. A.; Savka, M. A.; Szegedi, E.; Kawase, M.; Motohashi, N.; Molnar, J., Inhibition of quorum sensing and efflux pump system by trifluoromethyl ketone proton pump inhibitors. In vivo 2012, 26, 277-285.

94. Minagawa, S.; Inami, H.; Kato, T.; Sawada, S.; Yasuki, T.; Miyairi, S.; Horikawa, M.; Okuda, J.; Gotoh, N., RND type efflux pump system MexAB-OprM of Pseudomonas aeruginosa selects bacterial languages, 3-oxo-acyl-homoserine lactones, for cell-to-cell communication. BMC Microbiol. 2012, 12, 70-77.

95. Hong, K. W.; Koh, C. L.; Sam, C. K.; Yin, W. F.; Chan, K. G., Quorum quenching revisited--from signal decays to signalling confusion. Sens. 2012, 12, 4661-4696.

96. Cho, H. S.; Mason, K.; Ramyar, K. X.; Stanley, A. M.; Gabelli, S. B.; Denney, D. W., Jr.; Leahy, D. J., Structure of the extracellular region of HER2 alone and in complex with the Herceptin Fab. Nature 2003, 421, 756-760.

97. Sluis-Cremer, N.; Dmitrienko, G. I.; Balzarini, J.; Camarasa, M. J.; Parniak, M. A., Human immunodeficiency virus type 1 reverse transcriptase dimer destabilization by 1-[Spiro[4"-amino-2",2" -dioxo-1",2" -oxathiole-5",3'-[2', 5'bis-O-(tert-butyldimethylsilyl)-beta-D-ribofuranosyl]]]-3-ethylthy mine. Biochem. 2000, 39, 1427-1433.

98. Camarasa, M. J.; Velazquez, S.; San-Felix, A.; Perez-Perez, M. J.; Bonache, M. C.; De Castro, S., TSAO derivatives, inhibitors of HIV-1 reverse transcriptase dimerization: recent progress. Curr. Pharm. Des. 2006, 12, 1895-1907.

99. Perez-Perez, M. J.; San-Felix, A.; Balzarini, J.; De Clercq, E.; Camarasa, M. J., TSAO analogues. Stereospecific synthesis and anti-HIV-1 activity of 1-[2',5'-bisO-(tert-butyldimethylsilyl)-beta-D-ribofuranosyl]-3'-spiro -5"- (4"-amino-1",2"oxathiole 2",2"-dioxide) pyrimidine and pyrimidine-modified nucleosides. J. Med. Chem. 1992, 35, 2988-2995.

100. McMillan, K.; Adler, M.; Auld, D. S.; Baldwin, J. J.; Blasko, E.; Browne, L. J.; Chelsky, D.; Davey, D.; Dolle, R. E.; Eagen, K. A.; Erickson, S.; Feldman, R. I.; Glaser, C. B.; Mallari, C.; Morrissey, M. M.; Ohlmeyer, M. H. J.; Pan, C. H.; Parkinson, J. F.; Phillips, G. B.; Polokoff, M. A.; Sigal, N. H.; Vergona, R.; Whitlow, M.; Young, T. A.; Devlin, J. J., Allosteric inhibitors of inducible nitric oxide synthase dimerization discovered via combinatorial chemistry. Proc. Natl. Acad. Sci. U. S. A. 2000, 97, 1506-1511. 
101. Rajan, R.; Zhu, J.; Hu, X.; Pei, D.; Bell, C. E., Crystal Structure of SRibosylhomocysteinase (LuxS) in Complex with a Catalytic 2-Ketone Intermediate. Biochem. 2005, 44, 3745-3753.

102. Bhattacharyya, M.; Vishveshwara, S., Functional correlation of bacterial LuxS with their quaternary associations: interface analysis of the structure networks. BMC Struct. Biol. 2009, 9, 8-15.

103. R, L. Synthesis of S-ribosyl-L-homocysteine and analogs modified at the homocysteine-C3 position. University of San Francisco, 2012.

104. R, G. Biochemical evaluation of SRH analogs as potential LuxS inhibitors. University of San Francisco, 2012.

105. Koh, Y.; Matsumi, S.; Das, D.; Amano, M.; Davis, D. A.; Li, J.; Leschenko, S.; Baldridge, A.; Shioda, T.; Yarchoan, R.; Ghosh, A. K.; Mitsuya, H., Potent inhibition of HIV-1 replication by novel non-peptidyl small molecule inhibitors of protease dimerization. J. Biol. Chem. 2007, 282, 28709-28720.

106. Ason, B.; Handayani, R.; Williams, C. R.; Bertram, J. G.; Hingorani, M. M.; O'Donnell, M.; Goodman, M. F.; Bloom, L. B., Mechanism of loading the Escherichia coli DNA polymerase III beta sliding clamp on DNA. Bona fide primer/templates preferentially trigger the gamma complex to hydrolyze ATP and load the clamp. J. Biol. Chem. 2003, 278, 10033-10040.

107. Lee, H. H.; Yun, J.; Moon, J.; Han, B. W.; Lee, B. I.; Lee, J. Y.; Suh, S. W., Crystallization and preliminary $\mathrm{X}$-ray crystallographic analysis of enoyl-acyl carrier protein reductase from Helicobacter pylori. Acta Crystallogr. Sect. D. Biol. Crystallogr. 2002, 58, 1071-1073.

108. Li, X.; Chu, S.; Feher, V. A.; Khalili, M.; Nie, Z.; Margosiak, S.; Nikulin, V.; Levin, J.; Sprankle, K. G.; Tedder, M. E.; Almassy, R.; Appelt, K.; Yager, K. M., Structure-Based Design, Synthesis, and Antimicrobial Activity of IndazoleDerived SAH/MTA Nucleosidase Inhibitors. J. Med. Chem. 2003, 46, 5663-5673.

109. Ganin, H.; Tang, X.; Meijler, M. M., Inhibition of Pseudomonas aeruginosa quorum sensing by AI-2 analogs. Bioorg. Med. Chem. Lett. 2009, 19, 3941-3944.

110. Hentzer, M.; Wu, H.; Andersen, J. B.; Riedel, K.; Rasmussen, T. B.; Bagge, N.; Kumar, N.; Schembri, M. A.; Song, Z. J.; Kristoffersen, P.; Manefield, M.; Costerton, J. W.; Molin, S.; Eberl, L.; Steinberg, P.; Kjelleberg, S.; Hoiby, N.; Givskov, M., Attenuation of Pseudomonas aeruginosa virulence by quorum sensing inhibitors. EMBO J. 2003, 22, 3803-3815. 
111. Wu, H.; Song, Z.; Hentzer, M.; Andersen, J. B.; Molin, S.; Givskov, M.; Hoiby, N., Synthetic furanones inhibit quorum-sensing and enhance bacterial clearance in Pseudomonas aeruginosa lung infection in mice. J. Antimicrob. Chemother. 2004, 53, 1054-1061.

112. Hentzer, M.; Riedel, K.; Rasmussen, T. B.; Heydorn, A.; Andersen, J. B.; Parsek, M. R.; Rice, S. A.; Eberl, L.; Molin, S.; Hoiby, N.; Kjelleberg, S.; Givskov, M., Inhibition of quorum sensing in Pseudomonas aeruginosa biofilm bacteria by a halogenated furanone compound. Microbiol-Sgm 2002, 148, 87-102.

113. Roy, V.; Smith, J. A. I.; Wang, J.; Stewart, J. E.; Bentley, W. E.; Sintim, H. O., Synthetic Analogs Tailor Native AI-2 Signaling Across Bacterial Species. J. Am. Chem. Soc. 2010, 132, 11141-11150.

114. Lowery, C. A.; Park, J.; Kaufmann, G. F.; Janda, K. D., An unexpected switch in the modulation of AI-2-based quorum sensing discovered through synthetic 4,5dihydroxy-2,3-pentanedione analogues. J. Am. Chem. Soc. 2008, 130, 9200-9201.

115. Smith, J. A.; Wang, J.; Nguyen-Mau, S. M.; Lee, V.; Sintim, H. O., Biological screening of a diverse set of AI-2 analogues in Vibrio harveyi suggests that receptors which are involved in synergistic agonism of AI-2 and analogues are promiscuous. Chem. Commun. 2009, 7033-7035.

116. Ren, D.; Sims, J. J.; Wood, T. K., Inhibition of biofilm formation and swarming of Bacillus subtilis by (5Z)-4-bromo-5-(bromomethylene)-3-butyl-2(5H)furanone. Lett. Appl. Microbiol. 2002, 34, 293-299.

117. Janssens, J. C.; Steenackers, H.; Robijns, S.; Gellens, E.; Levin, J.; Zhao, H.; Hermans, K.; De Coster, D.; Verhoeven, T. L.; Marchal, K.; Vanderleyden, J.; De Vos, D. E.; De Keersmaecker, S. C., Brominated furanones inhibit biofilm formation by Salmonella enterica serovar Typhimurium. Appl. Environ. Microbiol. 2008, 74, 6639-6648.

118. Defoirdt, T.; Crab, R.; Wood, T. K.; Sorgeloos, P.; Verstraete, W.; Bossier, P., Quorum sensing-disrupting brominated furanones protect the gnotobiotic brine shrimp Artemia franciscana from pathogenic Vibrio harveyi, Vibrio campbellii, and Vibrio parahaemolyticus isolates. Appl. Environ. Microbiol. 2006, 72, 64196423.

119. Widmer, K. W.; Soni, K. A.; Hume, M. E.; Beier, R. C.; Jesudhasan, P.; Pillai, S. D., Identification of poultry meat-derived fatty acids functioning as quorum sensing signal inhibitors to autoinducer-2 (AI-2). J. Food Sci. 2007, 72, 363-368.

120. Marshall, J. A.; Seletsky, B. M.; Luke, G. P., Synthesis of Protected Carbohydrate-Derivatives through Homologation of Threose and Erythrose 
Derivatives with Chiral Gamma-Alkoxy Allylic Stannanes. J. Org. Chem. 1994, 59, 3413-3420.

121. Hori, H.; Nishida, Y.; Ohrui, H.; Meguro, H., Regioselective De-O-Benzylation with Lewis-Acids. J. Org. Chem. 1989, 54, 1346-1353.

122. Ortuno, R. M.; Alonso, D.; Font, J., Enantioselective Synthesis of (+)-(S)-BetaAngelica Lactone from L-Tartaric Acid. Tetrahedron Lett. 1986, 27, 1079-1080.

123. Wnuk, S. F.; Lalama, J.; Garmendia, C. A.; Robert, J.; Zhu, J.; Pei, D., SRibosylhomocysteine analogues with the carbon-5 and sulfur atoms replaced by a vinyl or (fluoro)vinyl unit. Bioorg. Med. Chem. 2008, 16, 5090-5102.

124. Wnuk, S. F.; Robert, J.; Sobczak, A. J.; Meyers, B. P.; Malladi, V. L. A.; Zhu, J. G.; Gopishetty, B.; Pei, D. H., Inhibition of S-ribosylhomocysteinase (LuxS) by substrate analogues modified at the ribosyl C-3 position. Biorg. Med. Chem. 2009, 17, 6699-6706.

125. Gopishetty, B.; Zhu, J.; Rajan, R.; Sobczak, A. J.; Wnuk, S. F.; Bell, C. E.; Pei, D., Probing the Catalytic Mechanism of S-Ribosylhomocysteinase (LuxS) with Catalytic Intermediates and Substrate Analogues. J. Am. Chem. Soc. 2008, 131, 1243-1250.

126. Malladi, V. L.; Sobczak, A. J.; Meyer, T. M.; Pei, D.; Wnuk, S. F., Inhibition of LuxS by S-ribosylhomocysteine analogues containing a [4-aza]ribose ring. Bioorg. Med. Chem. 2011, 19, 5507-5519.

127. Malladi, V. L.; Sobczak, A. J.; Maricic, N.; Murugapiran, S. K.; Schneper, L.; Makemson, J.; Mathee, K.; Wnuk, S. F., Substituted lactam and cyclic azahemiacetals modulate Pseudomonas aeruginosa quorum sensing. Bioorg. Med. Chem. 2011, 19, 5500-5506.

128. Lowery, C. A.; Abe, T.; Park, J.; Eubanks, L. M.; Sawada, D.; Kaufmann, G. F.; Janda, K. D., Revisiting AI-2 quorum sensing inhibitors: direct comparison of alkyl-DPD analogues and a natural product fimbrolide. J. Am. Chem. Soc. 2009, $131,15584-15585$.

129. Zhu, P.; Li, M., Recent progresses on AI-2 bacterial quorum sensing inhibitors. Curr. Med. Chem. 2012, 19, 174-86.

130. Cen, Y.; Sauve, A. A., Diastereocontrolled electrophilic fluorinations of 2deoxyribonolactone: syntheses of all corresponding 2-deoxy-2-fluorolactones and 2'-deoxy-2'-fluoro-NAD+s. J. Org. Chem. 2009, 74, 5779-5789. 
131. Reichman, U.; Watanabe, K. A.; Fox, J. J., A practical synthesis of 2-deoxy-2fluoro-D-arabinofuranose derivatives. Carbohydr. Res. 1975, 42, 233-240.

132. Robins, M. J.; Samano, V.; Johnson, M. D., Nucleic acid-related compounds. 58. Periodinane oxidation, selective primary deprotection, and remarkably stereoselective reduction of tert-butyldimethylsilyl-protected ribonucleosides. Synthesis of 9-(beta-D-xylofuranosyl)adenine or 3'-deuterioadenosine from adenosine. J. Org. Chem. 1990, 55, 410-412.

133. Tewson, T. J.; Welch, M. J., New approaches to the synthesis of 3-deoxy-3fluoro-D-glucose. J. Org. Chem. 1978, 43, 1090-1092.

134. Maddaford, A.; Guyot, T.; Leese, D.; Glen, R.; Hart, J.; Zhang, X.; Fisher, R.; Middleton, D.; Doherty, C.; Smith, N.; Pryde, D.; Sutton, S., Synthesis of Enantiomerically Pure 4-Substituted Riboses. Synlett 2007, 2007, 3149-3154.

135. Shin, D. H.; Lee, H. W.; Park, S. S.; Kim, J. H.; Jeong, L. S.; Chun, M. W., Synthesis of (-)-neplanocin A analogues as potential antiviral agents. Arch. Pharmacal Res. 2000, 23, 302-309.

136. Lenz, R.; Ley, S. V., Tetra-n-propylammonium perruthenate (TPAP)-catalysed oxidations of alcohols using molecular oxygen as a co-oxidant. J Chem Soc Perk 1997, 3291-3292.

137. Fernandez-Bolanos, J. G.; al-Masoudi, N. A.; Maya, I., Sugar derivatives having sulfur in the ring. Adv. Carbohydr. Chem. Biochem. 2001, 57, 21-98.

138. Grimshaw, C. E.; Whistler, R. L.; Cleland, W. W., Ring-Opening and Closing Rates for Thiosugars. J. Am. Chem. Soc. 1979, 101, 1521-1532.

139. Naka, T.; Minakawa, N.; Abe, H.; Kaga, D.; Matsuda, A., The Stereoselective Synthesis of $4^{6}-\beta$-Thioribonucleosides via the Pummerer Reaction. J. Am. Chem. Soc. 2000, 122, 7233-7243.

140. Jeong, L. S.; Lee, H. W.; Jacobson, K. A.; Kim, H. O.; Shin, D. H.; Lee, J. A.; Gao, Z.-G.; Lu, C.; Duong, H. T.; Gunaga, P.; Lee, S. K.; Jin, D. Z.; Chun, M. W.; Moon, H. R., Structure-Activity Relationships of 2-Chloro-N6-substituted$4^{6}$-thioadenosine-5'-uronamides as Highly Potent and Selective Agonists at the Human A3 Adenosine Receptor. J. Med. Chem. 2005, 49, 273-281.

141. Gunaga, P.; Kim, H. O.; Lee, H. W.; Tosh, D. K.; Ryu, J.-S.; Choi, S.; Jeong, L. S., Stereoselective Functionalization of the 1'-Position of 4'-Thionucleosides. Org. Lett. 2006, 8, 4267-4270. 
142. Wnuk, S. F.; Robins, M. J., Antimony(III) chloride exerts potent catalysis of the conversion of sulfoxides to .alpha.-fluoro thioethers with (diethylamino)sulfur trifluoride. Journal of Organic Chemistry 1990, 55, 4757-4760.

143. Robins, M. J.; Wnuk, S. F., Nucleic acid related compounds. 79. Efficient conversions of thioethers to alpha.-fluoro thioethers with DAST or DAST/antimony(III) chloride. J. Org. Chem. 1993, 58, 3800-3801.

144. Camilli, A.; Bassler, B. L., Bacterial small-molecule signaling pathways. Science 2006, 311, 1113-6.

145. O'Loughlin, C. T.; Miller, L. C.; Siryaporn, A.; Drescher, K.; Semmelhack, M. F.; Bassler, B. L., A quorum-sensing inhibitor blocks Pseudomonas aeruginosa virulence and biofilm formation. Proc Natl Acad Sci U S A 2013, 110, 17981-6.

146. Chugani, S. A.; Whiteley, M.; Lee, K. M.; D'Argenio, D.; Manoil, C.; Greenberg, E. P., QscR, a modulator of quorum-sensing signal synthesis and virulence in Pseudomonas aeruginosa. Proc Natl Acad Sci U S A 2001, 98, 2752-7.

147. Shin, D.; Lee, H.; Park, S.; Kim, J.; Jeong, L.; Chun, M., Synthesis of (-)neplanocin A analogues as potential antiviral agents. Arch. Pharm. Res. 2000, 23, 302-309.

148. Chugani, S. A.; Whiteley, M.; Lee, K. M.; D'Argenio, D.; Manoil, C.; Greenberg, E. P., QscR, a modulator of quorum-sensing signal synthesis and virulence in Pseudomonas aeruginosa. Proc. Natl. Acad. Sci. U. S. A. 2001, 98, 2752-2757.

149. Lee, W.-K.; Ogura, K.; Loh, J. T.; Cover, T. L.; Berg, D. E., Quantitative Effect of luxS Gene Inactivation on the Fitness of Helicobacter pylori. Appl. Environ. Microbiol. 2006, 72, 6615-6622.

150. Adonizio, A. L.; Downum, K.; Bennett, B. C.; Mathee, K., Anti-quorum sensing activity of medicinal plants in southern Florida. J. Ethnopharmacol. 2006, 105, 427-435.

151. Pearson, J. P.; Pesci, E. C.; Iglewski, B. H., Roles of Pseudomonas aeruginosa las and rhl quorum-sensing systems in control of elastase and rhamnolipid biosynthesis genes. J. Bacteriol. 1997, 179, 5756-5767.

152. Mathee, K.; Howe, M. M., Identification of a positive regulator of the Mu middle operon. J. Bacteriol. 1990, 172, 6641-6650.

153. Greenberg, E. P.; Hastings, J. W.; Ulitzur, S., Induction of luciferase synthesis in harveyi by other marine bacteria. Arch. Microbiol. 1979, 120, 87-91. 
VITA

\section{CHRISTIANE CHBIB}

Born, Beirut, Lebanon

2001-2005

B.S., Pharmacy

Lebanese American University

Beirut, Lebanon

2005-2007

Pharm.D.

Lebanese American University

Beirut, Lebanon

$2008-2013$

Clinical pharmacist

$2008-2014$

Doctoral candidate

Florida International University

Miami, FL

\section{PUBLICATIONS AND PRESENTATIONS}

Chbib, C., Mugdal, M., Gonzales, C., Lumpuy, D., Nagaj, J., Stokowa-Soltys, K., Sobczak, A., Wnuk, S.F. Synthesis, Inhibition of LuxS and Quorum sensing modulation by 4-C-substituted $S$-ribosylhomocysteine analogues. In preparation

Sobczak, A., Chbib, C., Kalai, M., Makemson, J., Pei, D., Wnuk, S.F. Inhibition of LuxS by S-ribosylhomocysteine containing a [4-thia]-ribose ring. In preparation

Saab, Y., Kabbara, W., Chbib, C., Gard, R. (2007). Buccal cell DNA extraction: yield, purity, and cost: a comparison of two methods. Genetic Testing, 11, 413-416. 